MINERALOGIA, 42, No 4: 163-297 (2011)

DOI: $10.2478 / v 10002-011-0012-9$

www.Mineralogia.pl

MineRALOGICAL SOCIETY OF POLAND

Polskie TOWARZYSTWO MINERALOgICZNE

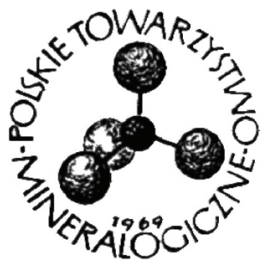

Original paper

\title{
Origin of marls from the Polish Outer Carpathians: lithological and sedimentological aspects
}

\author{
Katarzyna GÓRNIAK \\ AGH University of Sciences and Technology, Faculty of Geology, Geophysics and Environmental Protection, \\ al. Mickiewicza 30,30-059 Kraków,Poland; e-mail: gorniak@agh.edu.pl
}

Received: October 28, 2011

Received in revised form: February 20, 2012

Accepted: March 10, 2012

Available online: March 30, 2012

\begin{abstract}
Outcrops of marls, occurring within the sandstone-shaly flysch deposits of the Polish part of Outer Carpathians, considered to be locus typicus of these rocks, were described, measured and sampled. Lithologic features of marls, representing 15 complexes of different age and occurring in 15 complexes of various tectonic units, are presented (Fig. 1, 2). The present studies were concerning Jurassic marls from the Silesian Unit (Goleszów Marls), Upper Cretaceous marls from the Skole and Sub-Silesian Units (Siliceous-Fucoid and Węgierka Marls and Węglówka, Frydek, Jasienica and Żegocina Marls respectively), and Eocene-Oligocene marls from the Magura, Fore-Magura and Skole Units (Łącko, Zembrzyce, Budzów, Leluchów and Niwa, as well as Grybów and Sub-Cergowa and Dynów Marls respectively). The former opinions on lithology, age, formal subdivision, sedimentation conditions and genesis of these rocks are discussed (Table 1, 2; Fig. 1). Detailed description of the above mentioned marl-bearing complexes are presented and for each of them the typical lithological features are determined (Tables $3-20$ ). The results of profiling are presented against the background of geological studies of the Carpathian marls. The results of lithologic studies are compared to form a classification scheme and are used as the basis of distinguishing genetic types of marls. Moreover, the interpretation of the conditions of sedimentation of these rocks is presented.

According to the present author's studies, in the outcrops of marls considered to be locus typicus of the above mentioned rocks, there are both monolithic and polylithic complexes exposed. The polylithic complexes contain apart from marls intercalations of arenaceous-shaly flysch (Table 19). Event sedimentation of marly facies, appearing at different times and in various parts of the Carpathian basin is the result of periodically repeating conditions favouring the sedimentation of marls. Carpathian marls seem to be lithologically diversified. This is a natural for these rocks, uniting in variable proportions the features of limestones, clays, siliceous and clastic rocks. Depending on the proportions of these components, they display the features of the dominant one. The lithologies of Carpathian marls do not depend on their age and position in the sedimentation basin. Nevertheless, apart from visible differentiation of marls they show many common lithologic features: fine grain size, in general
\end{abstract}


corresponding to silty-clayey fraction, variable but usually considerable thickness of beds of nonarenaceous variety of marls $(0.5-1000 \mathrm{~cm})$ and small thickness of arenaceous one $(2-62 \mathrm{~cm})$. In the majority of marly complexes, the arenaceous variety, starved ripplemarks, thin sandstone beds and sandy lamines occur in bottom parts of marly beds. The majority of marls display variably developed lamination and the occurrence of burrows (Table 19). Taking into account the Ghibaudo's (1992) classification it was estimated that the marls in question can be assigned to three finest grained lithofacies: M (mud beds), MT (mud-silty couplets) and MS (mud-sand couplets) as well as to the MyG facies (muddy gravel). These lithofacies appear in marly complexes in various proportions (Table 20). Internal structures of beds are evidence of settling grains from suspension (depositional interval $\mathrm{e}_{2}$ ), interrupted with different intensity by deposition from traction (depositional intervals b, $\mathrm{d}$ and $\mathrm{e}_{1}$ ), and reworking of sediments by weak bottom currents (depositional intervals $\mathrm{c}$ and $\mathrm{c}_{0}$ ). The occurrence of similar lithologic features in marls of different age that come from different tectonic units is evidence of the repeating of similar sedimentation conditions, favouring the development of marly facies, at different times and in different parts of sedimentation basin of the Outer Carpathians.

According to the present author's analysis, there is a distinct relationship between the appearance of marls and tectonic evolution of the Outer Carpathian basin. Marls initiate sedimentation, indicate reconstruction stages and are closing the deposition in the Outer Carpathian basin (Fig. 1). Marls appear in the Polish part of Outer Carpathians in Upper Jurassic, initiating sedimentation in the northern Tethyan domain. Subsequently, they occur within Upper Cretaceous sandy-shaly flysch, indicating the reconstitution stage of Outer Carpathian basin and from Eocene to Oligocene are completing the deposition in successively closing basins (Fig. 1). The appearance of marls indicates the stages of tectonic evolution of the Outer Carpathians. The opening and reconstitution of a basin is accompanied by appearance of marls distinguished as preorogenic (Goleszów, Siliceous-Fucoid, Węgierka, Frydek and Żegocina Marls), their closing - synorogenic marls (Łącko, Budzów, Zembrzyce, Leluchów, Niwa, Grybów, Sub-Cergowa and Dynów Marls). Marls represent sediments redeposited from shelves to deeper parts of basins in the form of muds (M, MT and MS facies) and as olistostromes and olistoliths (MyG facies) (Tables 19, 20). Marls redeposited in the form of olistoliths appear in the stage of opening of the Outer Carpathian basin on the boundary of the Jurassic/Cretaceous period (Goleszów Marls) and in the stage of its Upper Cretaceous reconstitution (Baculite and Żegocina? Marls). In the complexes containing redeposited marls in the form of muds, submarine slumps occur (Table 19). These features indicate tectonic disquiet accompanying deposition of marls. Among the marls studied, dark coloured rocks appear (black, bluish-gray, greenish-gray) and olive and lightcoloured (creamy, beige), as well as variegated and red (Table 19). The differentiation of colours indicates sedimentation of Carpathian marls both in oxygenated environments and those that are oxygen-depleted. The analysis of evolution of the Carpathian basins indicates that they were starved basins during sedimentation of marls. Limited supply of clastic material in such basins suggests the discussion on the source of the clay minerals - one of essential components of marls. The occurrence of pyroclastic strata in sediments of the same age (Fig. 1) suggests their origin to be related to volcanic material.

The data of other authors, and the detailed profiling by the present author of outcrops that are considered to be locus typicus of marls and the appearance of which indicates a distinct correlation to tectonics of the Outer Carpathians, allowed to the present author to systematize and broaden the geological knowledge concerning the evolution of the marly facies in the northern part of the Tethyan Ocean. The conditions of sedimentation of marls deduced from the analysis of evolution of sedimentation basin of the Outer Carpathians and from lithologic data can be summarized as follows:

- marls appear episodically in the Outer-Carpathian basin (mono- and polylithic complexes) and determine the stages of its tectonic evolution; they initiate the stages of opening and indicate the reconstitution of basins (preorogenic marls) and closing sedimentation cycle (synorogenic marls);

- marls were deposited under conditions of tectonic disquiet (the presence of MyG facies), accompanied by volcanic activity (occurrence if pyroclastic rocks within chronostratigraphic equivalents of the marls studied);

- $\quad$ marly deposits were formed both under oxidizing and oxygen-depleted conditions, i.e. when the availability of oxygen in the bottom sediments was limited (variable colouration);

- marls represent the deposits of debris flows (MyG facies) redeposited from shelves in lithified form into zones that are situated close to the basin margins (olistoliths) and as resuspensed shelf muds accumulating 
within basinal sediments in the seafloor depressions (trap sediments) by suspension settling mechanism and periodically reworked by currents (M, MT, and MS facies).

Key-words: marls, Outer Carpathians, lithologic classification, lithofacies, northern Tethys, sedimentation conditions, tectonics, volcanism, origin of marls

\section{Contents}

1. Introduction ...................................................................................................... 168

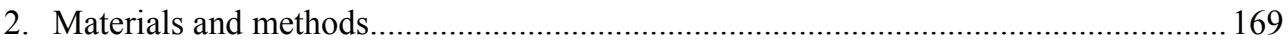

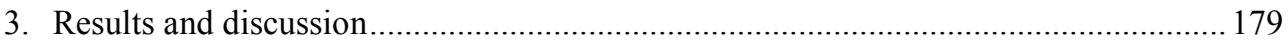

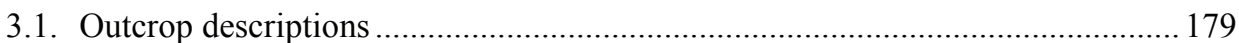

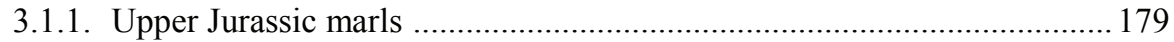

Goleszów Marls (marls from the Lower Cieszyn Beds)......................... 179

3.1.2. Upper Cretaceous marls............................................................... 183

Siliceous-Fucoid Marls .................................................................... 183

Węgierka (Baculite) Marls ................................................................ 189

Węglówka Marls............................................................................... 197

Frydek Marls ................................................................................ 202

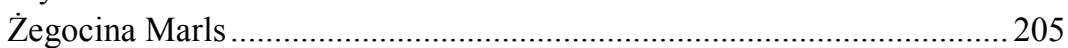

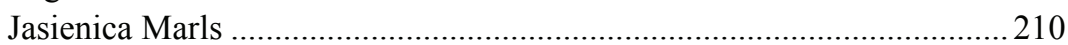

3.1.3. Eocene-Oligocene marls ........................................................................ 213

Łącko Marls ....................................................................................... 213

Zembrzyce Marls (marls from the Zembrzyce Beds) ............................ 217

Budzów Marls (marls from the Budzów Beds) ...................................... 227

Leluchów Marls ..................................................................................... 233

Niwa Marls (marls from the Malcov Beds) ............................................ 236

Grybów Marls........................................................................... 240

Sub-Cergowa (Jawornik) Marls.......................................................... 245

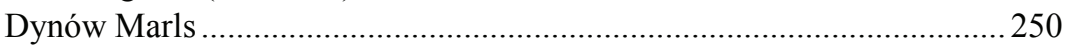

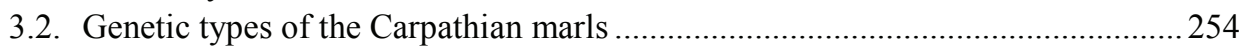

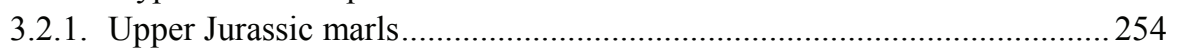

Goleszów Marls (marls from the Lower Cieszyn Beds) ............................ 254

3.2.2. Upper Cretaceous marls....................................................................... 264

Siliceous-Fucoid Marls .......................................................................... 264

Węgierka (Baculite) Marls .................................................................... 265

Węglówka Marls....................................................................................... 266

Frydek Marls ................................................................................. 269

Żegocina Marls .................................................................................... 271

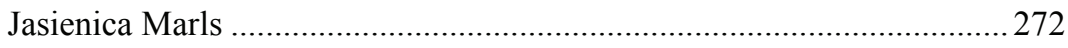

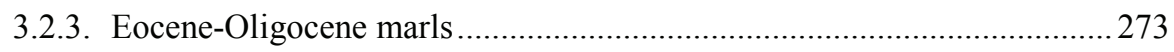

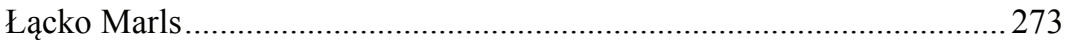

Zembrzyce Marls (marls from the Zembrzyce Beds) ............................. 275

Budzów Marls (marls from the Budzów Beds) ...................................... 277

Leluchów Marls................................................................................ 279 
Niwa Marls (marls from the Malcov Beds) ........................................ 280

Grybów Marls............................................................................. 281

Sub-Cergowa (Jawornik) Marls........................................................ 283

Dynów Marls ................................................................................ 285

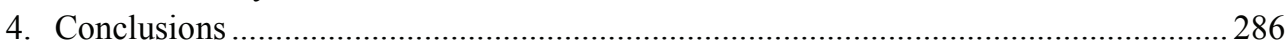

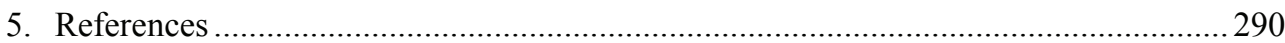

\section{Introduction}

In the Outer Carpathians, the name of marls is given to fine-grained calcareous rock that show differentiated lithologic features. When compared to sandstones and shales, marls are the least known component of the Outer Carpathian flysch. They were distinguished during field investigations, and for the majority of them only general macroscopic characteristics are available, dispersed in many papers. The study of Carpathian marls is difficult. As finegrained rocks, displaying in variable proportions the features of carbonates, clays, siliceous and clastic rocks they cannot be examined using traditional petrographic methods. Nevertheless, marls are important for the reconstruction of geologic evolution of the Outer Carpathians.

Marls appear in different periods (from Upper Jurassic to Oligocene) in all tectonic units of the Outer Carpathians. They occur within basinal sediments, often forming complexes up to many meters thick. Thick marly complexes are distinguished as separate lithostratigraphic units. Some of them are used as marker horizons.

The causes of marls appearing among deposits of sandstone-shaly flysch of the Outer Carpathians are not always known. It is thought that sediments, which after diagenesis became marls, were originally deposited under conditions corresponding to shelf environment and subsequently transported to deeper parts of sedimentation basins, both in a loose form as resuspended muds and as consolidated sediments, i.e. as olistoliths. Consequently, marls are one of very few rocks that recorded the conditions that existed in the shelves of the Carpathian basins.

The aim of the present author's studies is to explain the causes of the marls appearing among the sandstone-shaly flysch of the Outer Carpathians. This paper summarizes the data of many dispersed papers on the lithology of the Carpathian marls, as well as the opinions on their genesis and formal classification. For detailed studies, marls showing relation to tectonics of the Outer Carpathians were selected. To obtain a clear image of common features of marls and those differing from each other, the sampling, descriptions and measurements were carried out in stratotype outcrops that are considered to represent the locus typicus of these rocks.

The first part of this paper deals with lithological studies that document the conditions of sedimentation. It should be emphasized that in the case of marls, deciphering this record is rather difficult due to partial obliteration by diagenetic processes. Marl-bearing complexes and differentiation of lithology of Carpathian marls are described in detail. A new method for the description and classification of the Carpathian marls is proposed. Careful definition of the different lithologies of marls were defined based on colour, grain- 
size, stratification, internal structures of beds, abundance of bioturbation, induration, parting and splitting. Based on these investigations, the studied marls were assigned to the lithofacies of subaqueous sediment gravity flow deposits proposed by Ghibaudo (1992) and the conditions of their sedimentation were determined. In order to compare lithologic properties of Carpathian marls, their classification scheme was proposed. The results of lithological investigations presented in this paper are an integrated part of the monograph on science of the Outer Carpathian marls.

It should be emphasized that the science of Carpathian marls is important not only for the geology of the Carpathians, but also because of their significance for petroleum geology. Their microporous varieties are often reservoir rocks and organic-rich marls source beds for hydrocarbons.

Another reason of that the study of marls is important is their grain-size corresponding to mudrocks. Though these rocks are the most widespread in nature, publications concerning mudrocks are rare. This is caused by their fine grain-size, corresponding to mud and clay fractions, rendering their detailed investigation difficult. Therefore, elaboration of detailed lithological classifications of mudrocks is of considerable importance, also from practical viewpoint due to their engineering properties. Lithologic diversity of fine-grained rocks causes great contrast in the response of mudrocks to water and air or to a new stress environment. The results of detailed study of Carpathian marls, presented in this paper, can be considered to be a contribution to the knowledge of mudrocks - which are fairly common but relatively poorly understood rocks.

\section{Materials and methods}

The material selected by the present author for study represents 15 complexes of marls, which appeared at different times and in different sedimentation basins of the Outer Carpathians. The selected materials were sampled from Upper Jurassic Goleszów Marls, occurring in the Silesian Unit, Upper Cretaceous marls from the Skole and Sub-Silesian units (Siliceous-Fucoid, Węgierka, Węglówka, Frydek, Jasienica and Żegocina marls respectively), as well as from Eocene-Oligocene marls of the Magura Unit, Sub-Magura Units and Skole Unit (Łącko, Zembrzyce, Budzów, Leluchów, Niwa, Grybów, Sub-Cergowa and Dynów Marls respectively) (Table 1, 2; Fig. 1, 2). These marls, presented in the formal lithostratigraphic subdivision of the Polish Outer Carpathians, are listed in Table 2.

Fieldwork was carried out in 1989 - 2007. The profiling and sampling was accomplished in the surface outcrops that are considered to represent the locus typicus for the selected Outer Carpathian marls. In general they are small and their quality and state vary in time. Typical marls were subdivided based on lithologic features described in earlier papers of other authors. It should be emphasized that the term marls in the Outer Carpathians is used for rocks, which differ in lithological features such as: colour, grainsize, bedding, internal structures of beds, occurrence of burrows, induration and parting. For comparison purposes, a classification scheme for the Outer Carpathian marls was prepared, taking into account the varieties showing definite colour, arenaceous and nonarenaceous, laminated, structureless and bioturbated, and differing in induration, parting and splitting. 


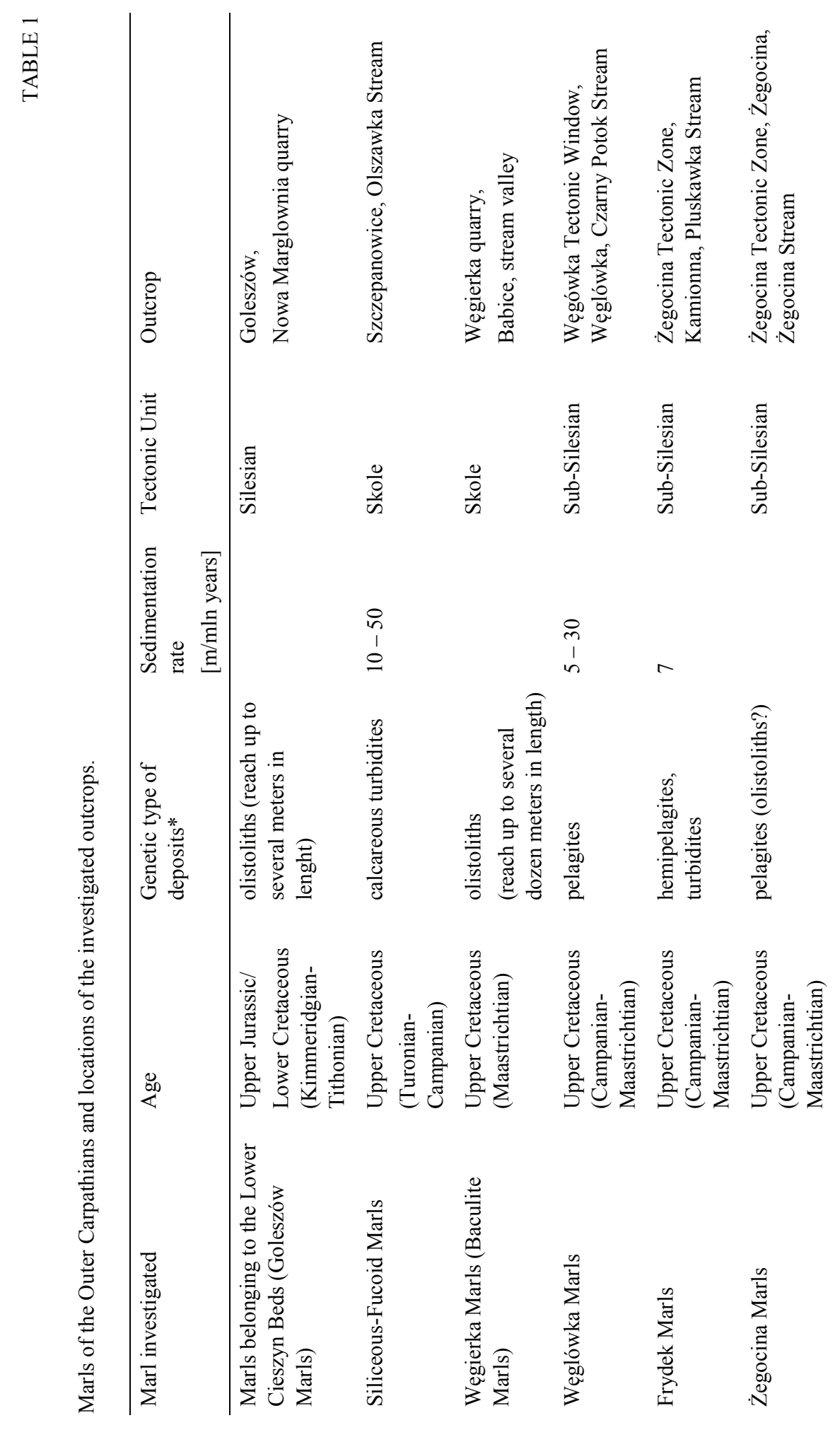




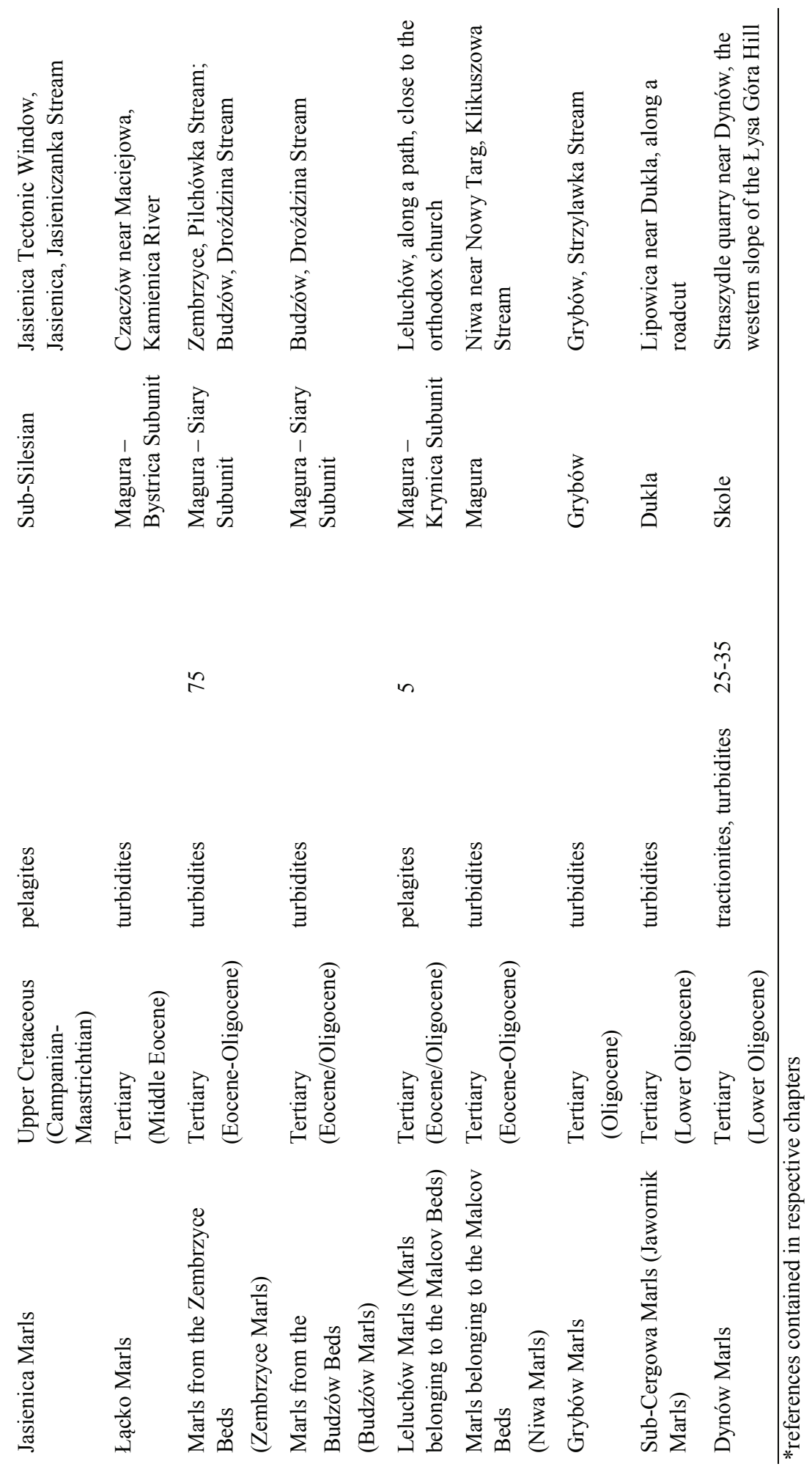


Formal lithostratigraphic position of the Outer Carpathian marls investigated.

\begin{tabular}{|c|c|c|c|c|c|}
\hline Marl investigated & $\begin{array}{l}\text { Member } \\
\mathrm{Mb}\end{array}$ & $\begin{array}{l}\text { Thickness } \\
{[\mathrm{m}]}\end{array}$ & $\begin{array}{l}\text { Formation } \\
\text { Fm }\end{array}$ & $\begin{array}{l}\text { Thickness } \\
{[\mathrm{m}]}\end{array}$ & Tectonic unit \\
\hline $\begin{array}{l}\text { Marls belonging to the } \\
\text { Lower Cieszyn Beds* } \\
\text { (Goleszów Marls) } \\
\text { (Kimmeridgian-Tithonian) }\end{array}$ & $\begin{array}{l}\text { Goleszów } \\
\text { Shales }\end{array}$ & up to 300 & Cieszyn & approx. 850 & Silesian \\
\hline $\begin{array}{l}\text { Siliceous-Fucoid Marls } \\
\text { (Turonian-Campanian) }\end{array}$ & $\begin{array}{l}\text { Cisowa } \\
\text { and Wiar }\end{array}$ & up to 500 & Ropianka & $300-1500$ & Skole \\
\hline $\begin{array}{l}\text { Węgierka Marls } \\
\text { (Maastrichtian) }\end{array}$ & Leszczyny & up to 300 & Ropianka & $300-1500$ & Skole \\
\hline $\begin{array}{l}\text { Węglówka Marls } \\
\text { (Campanian-Maastrichtian) }\end{array}$ & & & Węglówka & up to 600 & Sub-Silesian \\
\hline $\begin{array}{l}\text { Frydek Marls } \\
\text { (Campanian-Maastrichtian) }\end{array}$ & & & Frydek & $>100$ & Sub-Silesian \\
\hline $\begin{array}{l}\text { Żegocina Marls } \\
\text { (Campanian-Maastrichtian) }\end{array}$ & & & Żegocina & approx. 30 & Sub-Silesian \\
\hline $\begin{array}{l}\text { Jasienica Marls } \\
\text { (Campanian-Maastrichtian) }\end{array}$ & & & $\begin{array}{l}\text { Jasienica } \\
\text { Marls }\end{array}$ & up to 20 & Sub-Silesian \\
\hline $\begin{array}{l}\text { Łącko Marls } \\
\text { (mostly Middle Eocene) }\end{array}$ & Maszkowce & $25-1620$ & Magura & up to 3500 & Magura \\
\hline $\begin{array}{l}\text { Zembrzyce Marls (mostly } \\
\text { Upper Eocene) }\end{array}$ & $\begin{array}{l}\text { Zembrzyce } \\
\text { Shale } \\
\text { (Beds) }\end{array}$ & up to 2000 & Magura & up to 3000 & Magura \\
\hline $\begin{array}{l}\text { Budzów Marls (mostly } \\
\text { Lower Oligocene) }\end{array}$ & $\begin{array}{l}\text { Budzów } \\
\text { Shale } \\
\text { (Beds) }\end{array}$ & $75-750$ & Magura & up to 3000 & Magura \\
\hline $\begin{array}{l}\text { Leluchów Marls } \\
\text { (Uppermost Priabonian- } \\
\text { Lowermost Rupelian) }\end{array}$ & $\begin{array}{l}\text { Leluchów } \\
\text { Marls }\end{array}$ & 4 & Malcov & approx. 40 & Magura \\
\hline $\begin{array}{l}\text { Niwa Marls (Uppermost } \\
\text { Eocene-Lower Oligocene) }\end{array}$ & & & Malcov & $600-800$ & Magura \\
\hline Grybów (Oligocene) & $\begin{array}{l}\text { Grybów } \\
\text { Marls }\end{array}$ & up to 400 & Menilite & $>600 ?$ & Grybów \\
\hline $\begin{array}{l}\text { Sub-Cergowa Marls (Lower } \\
\text { Oligocene) }\end{array}$ & $\begin{array}{l}\text { Jawornik } \\
\text { Marls }\end{array}$ & $20-150$ & Menilite & $1000-1200$ & Dukla \\
\hline $\begin{array}{l}\text { Dynów Marls (Lower } \\
\text { Oligocene) }\end{array}$ & $\begin{array}{l}\text { Dynów } \\
\text { Marls }\end{array}$ & $15-20$ & Menilite & up to 700 & Skole \\
\hline
\end{tabular}

* now Vendrynĕ Formation 


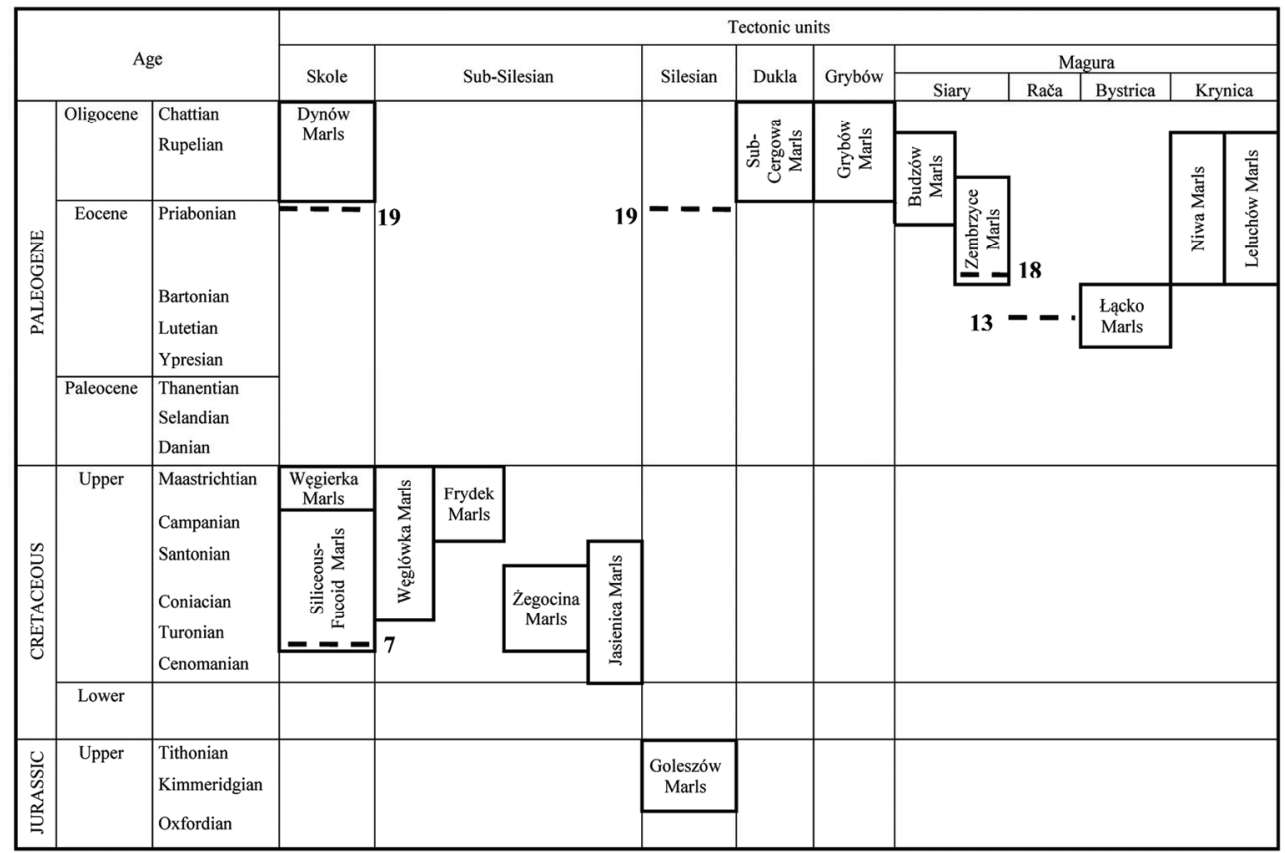

Fig. 1. Chronostratigraphy of the Polish Outer Carpathian marls investigated; dashed lines denote a position of associated tuff horizons. The position of tuff horizons and their identification numbers are based on Wieser (1985, fig. 10).

Explanation: 7 - Rybotycze; 13 - Polany (41.7 \pm 1.7 mln.y.); 18 - Pewel Mała (average $36.9 \pm$ 1.9 mln.y.); 19 - Gąsiory-Znamirowice (34.6 \pm 1.4 mln.y.) For genetic type of marls studied see Tables: 1,19 and 20.

The colour of marls was the base to distinguish black, gray with bluish or greenish tint, light and dark-brown, as well as variegated and red varieties. For comparison purposes in the generalized descriptions of the outcrops, the marls were assigned to the abovementioned generalized varieties. To emphasize the distinguishing properties, the tints of colours in detailed characteristics of marls in individual outcrops were also taken into account.

Grain-size - this term was used as size terms, bearing no connotation of composition. On this basis, arenaceous and nonarenaceous varieties of marls were distinguished. The arenaceous variety is distinguished by the volumetric content of silt- and fine sand-sized grains exceeding 2/3. In the case of the Goleszów Marls, the terminology used by Peszat (1968) was preserved (aleuritic and psammitic varieties). 


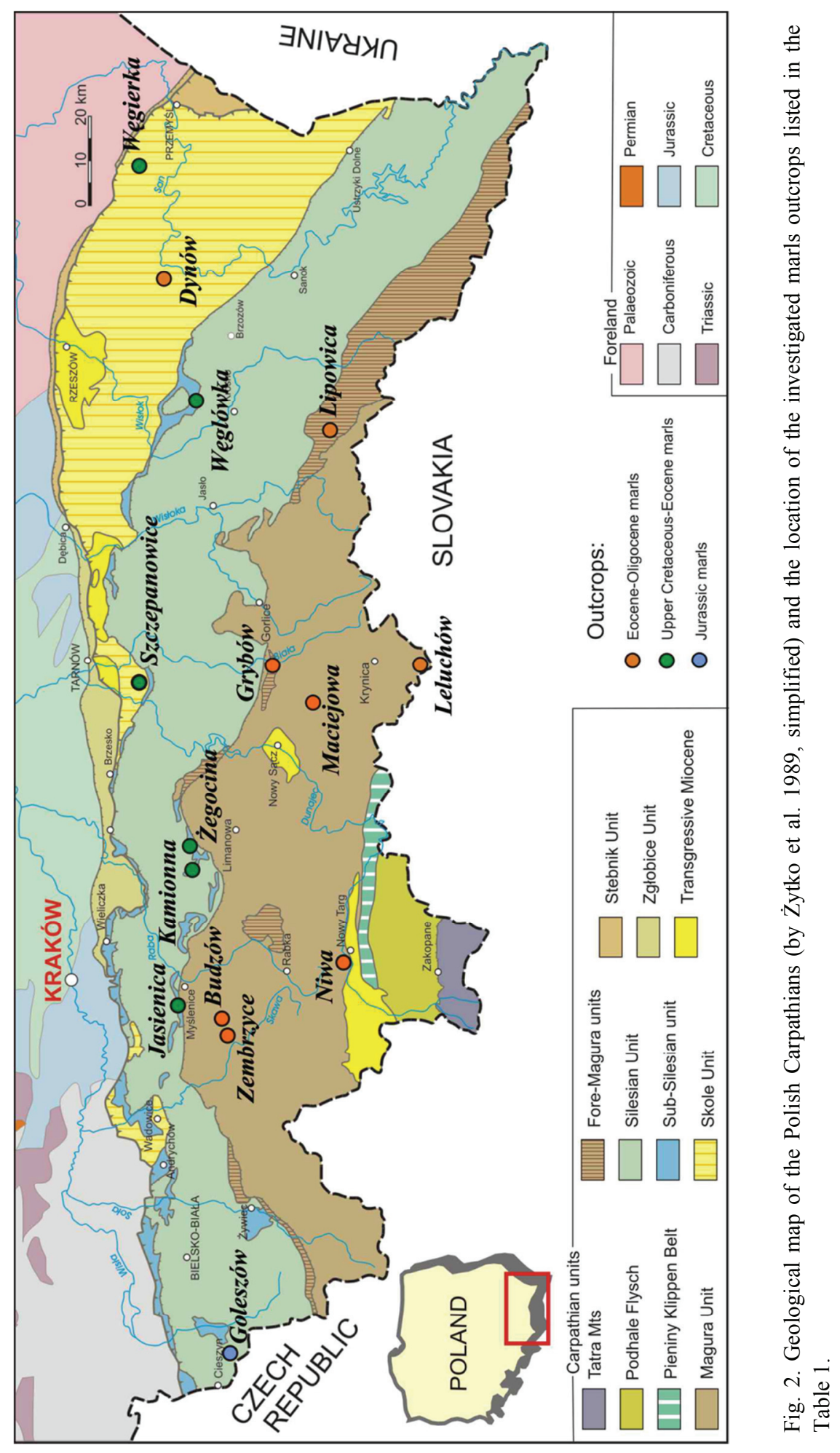


Descriptive terms for bed and laminae thickness were used. The bedding of marls is classified according to the system proposed by McKee and Weir (1953), vide Boggs (2009, Tab. 3.1). Very thin beds are below $3 \mathrm{~cm}$ thick, thin beds $-3-10 \mathrm{~cm}$, medium beds -10 $30 \mathrm{~cm}$, thick beds $-30-100 \mathrm{~cm}$ and very thick beds - more than $100 \mathrm{~cm}$.

The bed's internal structures were the basis to distinguish parallel, wavy, crosslaminated and structureless varieties of marls. The thickness of laminae was described according to the classification published by Potter et al. (1980, Tab. 1.3). The term 'very thin' was used for laminae less than $0.5 \mathrm{~mm}$ thick, 'thin' for those $0.5-1 \mathrm{~mm}$, 'medium' for those $1-5 \mathrm{~mm}$ and 'thick' for those $5-10 \mathrm{~mm}$ thick. To fully describe the bed's internal structures of rocks studied, the polished slabs were examined, revealing more distinct lamination, usually delicate and therefore, because of the fine grain size of marls, not easily visible on broken surfaces.

The quantity of bioturbations was taken into account to evaluate the relative intensity of reworking the bottom muds by organisms, related to availability of nutrients and oxygen during and shortly after deposition. High and low degrees of bioturbation were distinguished.

The induration of marls was described by distinguishing split hard, hard, brittle hard and soft rocks. Also, the differential response of marls to water was taken into account.

The parting of marls visible in outcrops, showing weathering expression of stratification, was characterized using terminology that was proposed by Potter et al. (1980, Tab. 1.3). Apart from massive, non-fissile rocks, the following types of parting were distinguished: slabby (above $10 \mathrm{~mm}$ thick) and flaggy $(5-10 \mathrm{~mm}$ ). The shape of splitters, forming after hammering, was described using the subdivision proposed by Grainger (vide Potter et al. 2005, Fig. A.4). Two varieties of fracture of marls were distinguished showing platy and flaky fragmentation, i.e. those that break with flat parting surfaces and those that are conchoidal in shape respectively.

In the course of the present author's studies, 16 outcrops of marly complexes were described, measured and sampled. The total length of profiles, composed of 973 beds of marls and accompanying rocks (sandstones, calcareous and noncalcareous shales, limestones, ferrous dolomites and cherts), amounted to 260 meters. Moreover, six olistoliths were sampled. 351 samples were collected for detailed examination (Table 3). The profiles were characterized quantitatively. However, the investigated outcrops usually represent a small fragment of a member or formation containing marls. Therefore, the calculated thickness and frequency percentages and average thicknesses of beds of the distinguished types and varieties of rocks are only indicative.

The frequency percentage of sandstones in marl-bearing complexes was the basis of distinguishing their mono- and polylithic types. This criterion was used taking into account the opinion that transport directions for sandstones are different than those for marls (Lącko Marls) (Bromowicz 1992a; Bromowicz, Górniak 1988). 
Sampling.

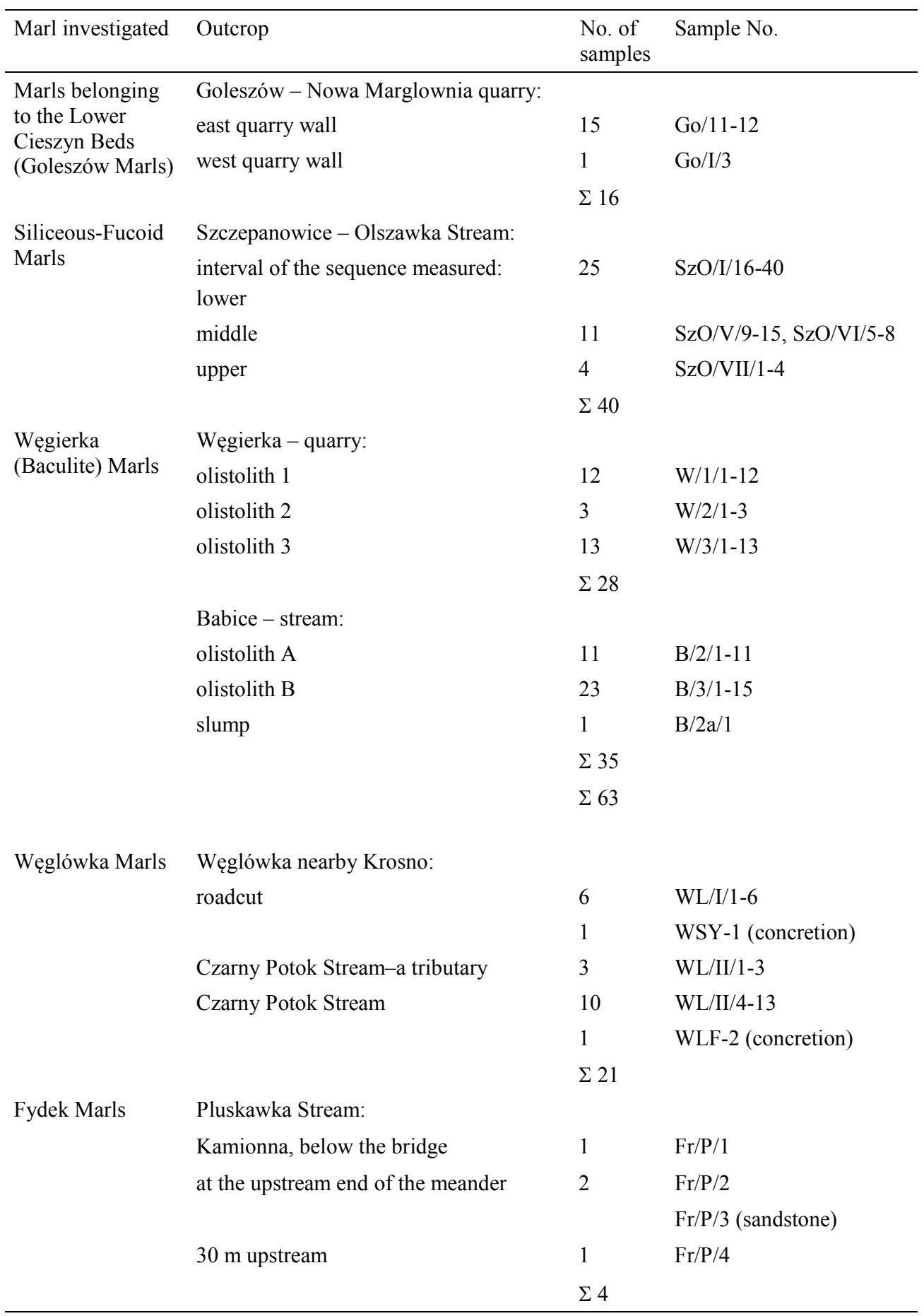


cont. TABLE 3

\begin{tabular}{|c|c|c|c|}
\hline Marl investigated & Outcrop & $\begin{array}{l}\text { No. of } \\
\text { samples }\end{array}$ & Sample No. \\
\hline \multirow[t]{8}{*}{ Żegocina Marls } & Żegocina Stream: & & \\
\hline & \multirow{4}{*}{$\begin{array}{l}\text { at the foot of the church, on the left side } \\
\text { of the stream }\end{array}$} & 7 & $\mathrm{Ze} / \mathrm{I} / 3 \mathrm{a}-\mathrm{b}, 5,7,9-11$ \\
\hline & & 2 & $\mathrm{Ze} / \mathrm{I} / 3 \mathrm{c}, 6$ (shales) \\
\hline & & 3 & $\mathrm{Ze} / \mathrm{I} / 3 \mathrm{~d}, 8,13$ (cherts) \\
\hline & & 2 & Ze/I/1-2 (black shales) \\
\hline & at the waterfall & 1 & $\mathrm{Ze} / \mathrm{II} / 12$ \\
\hline & \multirow[t]{2}{*}{ Pluskawka Stream } & 1 & $\mathrm{Ze} / \mathrm{P}$ \\
\hline & & $\Sigma 16$ & \\
\hline \multirow[t]{5}{*}{ Jasienica Marls } & \multicolumn{3}{|l|}{ Jasieniczanka Stream: } \\
\hline & \multirow[t]{2}{*}{$\begin{array}{l}2 \mathrm{~km} \text { from the entrance to the Jasienica } \\
\text { Village }\end{array}$} & 12 & $\begin{array}{l}\mathrm{Ja} / \mathrm{II} / 1,2,3,5 \mathrm{a}-\mathrm{c}, 7,9,10, \\
12,13\end{array}$ \\
\hline & & 3 & $\mathrm{Ja} / \mathrm{II} / 6,8,11$ (shales) \\
\hline & \multirow[t]{2}{*}{$50 \mathrm{~m}$ upstream } & 1 & $\mathrm{Ja} / \mathrm{III}$ \\
\hline & & $\Sigma 16$ & \\
\hline \multirow[t]{5}{*}{ Łącko Marls } & \multirow{5}{*}{$\begin{array}{l}\text { Kamienica River, } \\
100 \mathrm{~m} \text { upstream from the outlet of the } \\
\text { Czaczowiec Stream }\end{array}$} & 2 & $\begin{array}{l}\mathrm{Mł} / 4 / 20,39 \mathrm{~d} \text { (arenaceous } \\
\text { marls) }\end{array}$ \\
\hline & & 3 & $\begin{array}{l}\mathrm{M} / / 4 / 39 \mathrm{~g}, 105 \mathrm{~d}, 105 \mathrm{~g} \\
\text { (nonarenaceous marls) }\end{array}$ \\
\hline & & 4 & $\begin{array}{l}\mathrm{M} / / 4 / 40,48,106,114 \mathrm{~s} \\
\text { (shales) }\end{array}$ \\
\hline & & 3 & $\begin{array}{l}\text { Mł/4/9d, 51d, } 77 \\
\text { (sandstones) }\end{array}$ \\
\hline & & $\Sigma 12$ & \\
\hline \multirow{11}{*}{$\begin{array}{l}\text { Marls from the } \\
\text { Zembrzyce Beds } \\
\text { (Zembrzyce } \\
\text { Marls) }\end{array}$} & \multirow[t]{6}{*}{ Zembrzyce, Pilchówka Stream } & 10 & $\begin{array}{l}\mathrm{ZM} / 1,2,5,7,8,12,14 \\
16,18,22 \text { (nonarenacous } \\
\text { marls) }\end{array}$ \\
\hline & & 9 & $\mathrm{ZM} / 11,15,21 ; \mathrm{ZM} / 3,4,10$ \\
\hline & & & $\begin{array}{l}13,19,20 \text { (arenaceous } \\
\text { marls) }\end{array}$ \\
\hline & & 2 & ZM/6, 17 (sandstones) \\
\hline & & 1 & ZM/9 (bentonite?) \\
\hline & & $\Sigma 22$ & \\
\hline & \multirow[t]{5}{*}{$\begin{array}{l}\text { Budzów, at the Droździna Stream } \\
\text { bifurcation }\end{array}$} & 1 & $\begin{array}{l}\mathrm{Bu} / \mathrm{III} / 20 \text { (nonarenaceous } \\
\text { marls) }\end{array}$ \\
\hline & & 2 & $\begin{array}{l}\mathrm{Bu} / \mathrm{III} / 17,19 \text { (arenaceous } \\
\text { marls) }\end{array}$ \\
\hline & & 1 & Bu/III/18 (sandstone) \\
\hline & & $\Sigma 4$ & \\
\hline & & $\Sigma 26$ & \\
\hline
\end{tabular}


cont. TABLE 3

\begin{tabular}{|c|c|c|c|}
\hline Marl investigated & Outcrop & $\begin{array}{l}\text { No. of } \\
\text { samples }\end{array}$ & Sample No. \\
\hline \multirow[t]{4}{*}{$\begin{array}{l}\text { Marls from the } \\
\text { Budzów Beds } \\
\text { (Budzów Marls) }\end{array}$} & \multirow[t]{4}{*}{ Budzów, Droździna Stream } & 8 & $\begin{array}{l}\mathrm{Bu} / \mathrm{I} / 1,9,3,4,15, \mathrm{Bu} / \mathrm{II} / 21 \\
22,23 \text { (nonarenaceous } \\
\text { marls) }\end{array}$ \\
\hline & & 11 & $\begin{array}{l}\mathrm{Bu} / \mathrm{I} / 2 \mathrm{a}, \mathrm{b}, 5,6,10-14,16 \\
\mathrm{Bu} / \mathrm{II} / 24 \text { (arenaceous marls) }\end{array}$ \\
\hline & & 3 & $\mathrm{Bu} / \mathrm{I} / 7,8 \mathrm{a}, \mathrm{b}$ (sandstones) \\
\hline & & $\Sigma 22$ & \\
\hline \multirow[t]{2}{*}{ Leluchów Marls } & \multirow{2}{*}{$\begin{array}{l}\text { Leluchów, a path close to the } \\
\text { Orthodox Church }\end{array}$} & 8 & $\mathrm{Le} / \mathrm{I} / 1-8$ \\
\hline & & $\Sigma 8$ & \\
\hline \multirow{4}{*}{$\begin{array}{l}\text { Marls belonging } \\
\text { to the Malcov } \\
\text { Beds (Niwa } \\
\text { Marls) }\end{array}$} & \multirow{4}{*}{$\begin{array}{l}\text { Niwa nearby Nowy Targ, Klikuszowa } \\
\text { Stream }\end{array}$} & 4 & $\mathrm{Ni} / \mathrm{I} / 3,6,7,9$ (soft marls) \\
\hline & & 3 & $\mathrm{Ni} / \mathrm{I} / 2,4,5$ (hard marls) \\
\hline & & 2 & $\mathrm{Ni} / \mathrm{I} / 1,8$ (calcareous shales) \\
\hline & & $\Sigma 9$ & \\
\hline \multirow[t]{11}{*}{ Grybów Marls } & \multirow[t]{4}{*}{ Strzylawka Stream } & 7 & $\mathrm{Gr} / \mathrm{I} / 1-3,5,7,8,10$ \\
\hline & & 1 & Gr/I/4 (limestone) \\
\hline & & 2 & $\mathrm{Gr} / \mathrm{I} / 6,9$ (sandstones) \\
\hline & & $\Sigma 10$ & \\
\hline & \multirow[t]{7}{*}{$\begin{array}{l}\text { right tributary of the Strzylawka } \\
\text { Stream }\end{array}$} & 12 & $\begin{array}{l}\mathrm{Gr} / \mathrm{II} / 1-4,7,8,12,14-16,19, \\
20\end{array}$ \\
\hline & & 1 & Gr/II/10 (limestone) \\
\hline & & 4 & $\begin{array}{l}\mathrm{Gr} / \mathrm{II} / 9,13,17,18(\mathrm{Fe}- \\
\text { dolomite) }\end{array}$ \\
\hline & & 3 & $\mathrm{Gr} / \mathrm{II} / 5,6,22$ (sandstones) \\
\hline & & 2 & Gr/II/ 11, 21 (shales) \\
\hline & & $\Sigma 22$ & \\
\hline & & $\Sigma 32$ & \\
\hline \multirow[t]{6}{*}{$\begin{array}{l}\text { Sub-Cergowa } \\
\text { (Jawornik) Marls }\end{array}$} & \multirow[t]{6}{*}{$\begin{array}{l}\text { Lipowica, small quarry at the base of a } \\
\text { steep slope on west side of the Dukla - } \\
\text { Barwinek road }\end{array}$} & 27 & $\begin{array}{l}\mathrm{Li} / \mathrm{I} / 1,3,5,7-9,11,13,15, \\
17,18,22,24,26,27,29,30, \\
32,34,36,37 \mathrm{a}, \mathrm{b}, 39,43,44, \\
45,45 \mathrm{k}\end{array}$ \\
\hline & & 14 & $\begin{array}{l}\mathrm{Li} / \mathrm{I} / 2,4,6,10,12,14,16, \\
17 \mathrm{a}, 19,20,21,22 \mathrm{a}, 24 \mathrm{a}, 28 \\
\text { (calcareous shales) }\end{array}$ \\
\hline & & 4 & $\mathrm{Li} / \mathrm{I} / 23,25,35,36 \mathrm{a}$ (cherts) \\
\hline & & 4 & $\begin{array}{l}\mathrm{Li} / \mathrm{I} / 30 \mathrm{a}, 33 \mathrm{~b}, 38,41 \\
\text { (noncalcareous shales) }\end{array}$ \\
\hline & & 4 & $\begin{array}{l}\mathrm{Li} / \mathrm{I} / 31,33 \mathrm{a}, 40,42 \\
\text { (sandstones) }\end{array}$ \\
\hline & & $\Sigma 53$ & \\
\hline
\end{tabular}




\begin{tabular}{llll}
\hline Marl investigated & Outcrop & $\begin{array}{l}\text { No. of } \\
\text { samples }\end{array}$ & Sample No. \\
\hline Dynów Marls & $\begin{array}{l}\text { Straszydle near Dynów, the Łysa Góra } \\
\text { quarry }\end{array}$ & 10 & $\begin{array}{l}\text { Dy/I/1b, 2, 3a, 4-6, 9-12, } \\
\text { (slabby marls) }\end{array}$ \\
& & 1 & Dy/I/7 (flaggy marls) \\
& 2 & Dy/I/3b,8 (cherts) \\
& 1 & Dy/I/1a (sandstone) \\
& $\sum 14$ & \\
Total: & $\sum 351$ & \\
\hline
\end{tabular}

Facies analysis was carried out using Ghibaudo's (1992) classification. Facies of marlbearing complexes were distinguished based on the bed's grain-size, thickness and sand/mud or silt/mud thickness ratio in composite beds. Subfacies, i.e. sequences of depositional processes, were described on the basis of bed's internal structures. Depositional intervals (bed divisions), considered to represent successive depositional stages during individual sequences of depositional processes, were used for detailed interpretation of the mechanism of depositional processes of marly beds. The interpretation of the record of depositional processes mechanism inferred for different bed divisions was made according to Ghibaudo (1992, Table 5). The descriptive coding system, proposed by Ghibaudo (1992), is used as size terms bearing no connotation of composition.

The results of lithologic studies of 15 complexes of Carpathian marls are presented at the background of actual state of knowledge and presented in two chapters: 'Results of profiling' and 'Genetic types of Carpathian marls'. The beginning of each chapter contains the review of actual state of studies. The results of profiling are discussed, and are compared in Tables from 4-18 and presented in Figures from 3-18. The second of these chapters contains interpretation of the sedimentation environment of marls based on the results of author's lithological studies of selected profiles. The interpretation of the lithologic examination of Carpathian marls is compared in Tables 19 and 20.

\section{Results and discussion}

\subsection{Outcrop descriptions}

\subsubsection{Upper Jurassic marls}

\section{Goleszów Marls (marls from the Lower Cieszyn Beds)}

\section{Geological background}

The Goleszów Marls (Table 1; Figs. 1,2) are a member of the Lower Cieszyn Shales (Kimmeridgian - Tithonian). The Lower Cieszyn Shales in the formal stratigraphic subdivision called the Goleszów Marly Shales Member (Wójcik et al. 1996), which is now included in the Vendryně Formation (Golonka et al. 2008) (Table 2), occurs only in the Western Flysch Carpathians. They are distinguished in the bottom of the Cieszyn Beds, 
called the Cieszyn Formation (Wójcik et al. 1996), which forms the lower part of the Silesian Unit (Fig. 2; Tables 1, 2), that was separated during the folding of the Carpathians and called the Cieszyn Nappe (Książkiewicz 1972).

The thickness of the Goleszów Marly Shales Member is up to $300 \mathrm{~m}$ (Słomka et al. 2006). They are represented by marly shales, detrital, organodetrital and pelitic limestones, and marls. In the top part of this member there are also clayey conglomerates that contain andesite exotics (Nowak 1973a).

The Goleszów Marly Shales Member tectonically overlies the Cretaceous and Palaeogene series of the Sub-Silesian Unit or the Miocene deposits of the Carpathian Foredeep (Nowak; 1973a).

The Goleszów Marly Shales Member is overlain by calcareous flysch deposits, about 550 meters thick, containing two younger members of the Cieszyn Formation (Wójcik et al. 1996): Cieszyn Limestones (Upper Tithonian - Valanginian in age according to Olszewska et al. 2008), up to 250 meters thick, representing deposits of submarine fans (Słomka, 1986a), and Upper Cieszyn Shales (Valanginian - Hauterivian), up to 300 meters thick. All these members of the Cieszyn Formation are penetrated by teschenite intrusions. It should be noted that the Cieszyn Limestones, in new formal stratigraphic subdivision, are called the Cieszyn Limestone Formation. The Upper Cieszyn Shales (now Cisownica Shale Member) were included into the Hradistě Formation (Golonka et al. 2008).

\section{Previous works}

The oldest series of the Cieszyn Formation (Goleszów Marly Shales Member vel Vendryně Formation) that contains olistoliths of marls (Goleszów Marls) studied by the present author, are best exposed in the abandoned quarry Nowa Marglownia in Goleszów near Skoczów (Fig. 2; Tables 1, 3, 4). The olistostrome exposed in the eastern part of this quarry was studied by Peszat $(1968,1971)$ and Słomka (1986b).

\section{$\underline{\text { Results of fieldworks }}$}

\section{Detailed outcrop descriptions}

In the last decade of the former century, in this outcrop of over than 30 meters high, it was possible to observe black, hard, calcareous, poorly arenaceous shales, that showed coarse leaflike fissility, as well as dark gray detrital limestones and arenaceous marls.

In the lower part of this outcrop (Fig. 3) these shales contain scarce limestone intercalations. They are very thin $(1-2 \mathrm{~cm})$ and usually disrupted. Their bottom and top surfaces are uneven and contact sharply with shales. In the uppermost part of the wall of this quarry the limestone beds are thicker $(10-15 \mathrm{~cm})$ and more numerous. The transition from limestone-shale becomes continuous due to concentration of parallel and/or crosslamination in alternating carbonate and mud. Olistoliths of both structureless, well-lithified, detrital limestones and of blocky marls appear mainly in the middle part of this outcrop. These blocks between several meters and a dozen meters in size, lenticular, whereby their longer axes show parallel orientation (Fig. 3). Besides, a fragment of olistolith of bedded marls was outcropped in the western wall, at the entrance to this quarry. All the rocks occurring in this olistostrome are very fissured and the cracks are filled with calcite. 16 representative samples of all the rock types occurring in this quarry were collected for detailed studies (Fig. 3; Tables 3, 4). The samples of marls are from the matrix (marly 
shales) and all the olistoliths (blocky and bedded marls varieties) occurring in the Goleszów quarry.

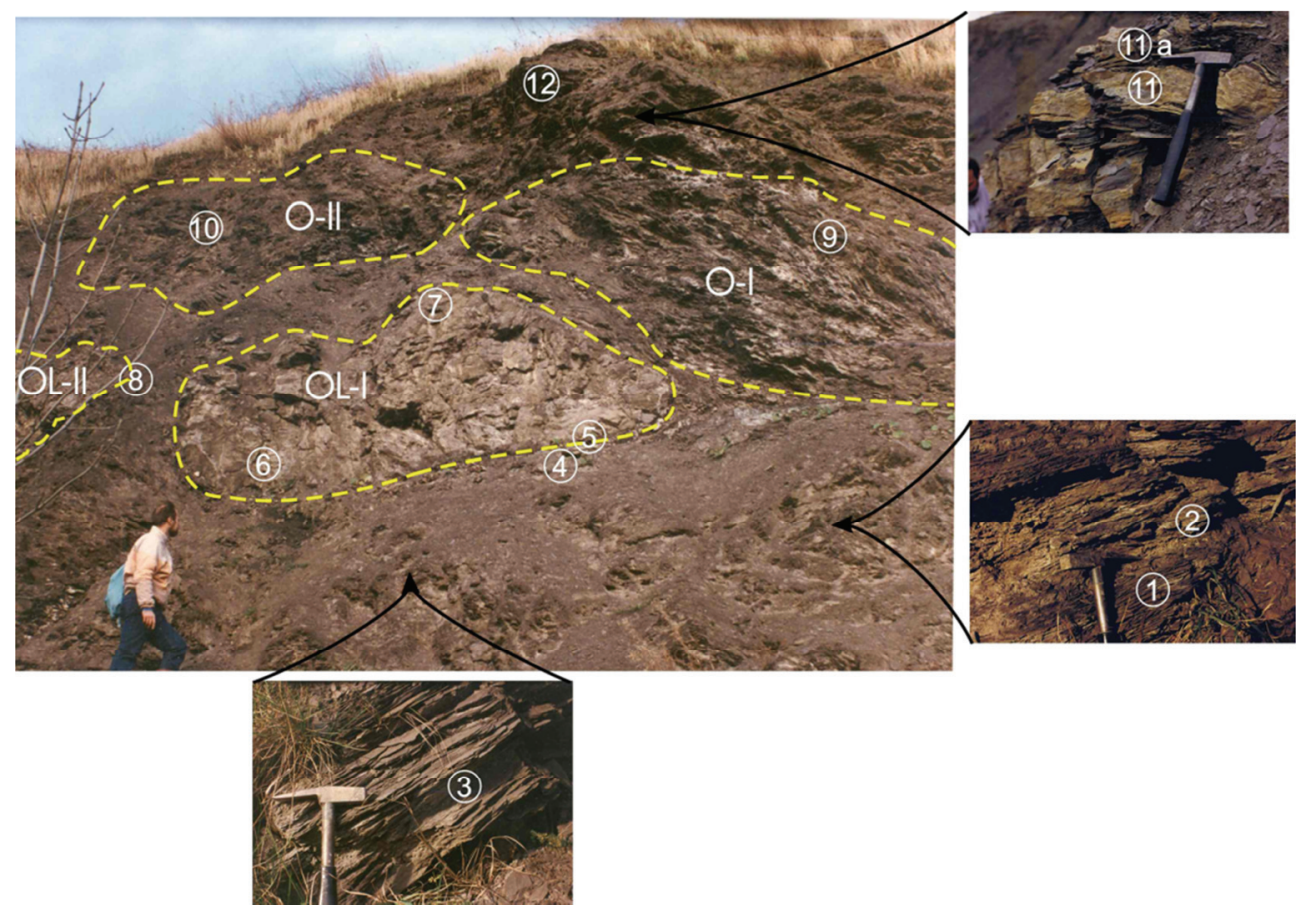

Fig. 3. Marls belonging to the Lower Cieszyn Beds (Goleszów Marls) uncovered at the Nowa Marglownia quarry (Goleszów) in the autumn of 1998 (eastern quarry wall).

Explanations: $\mathrm{O}$ - marl olistoliths; Ol - limestone olistoliths; 1 - 12a - samples. Small photographs show details of matrix. Samples are listed in the Table 4.

The shales are coal-black, beige-black, show fissile parting, aleuritic, contain mica flakes visible on the fissility surfaces, fairly hard, strongly calcareous and are distinctly laminated. Lamination is faint, horizontal, accented by the change of colouration intensity. These rocks resemble aleuritic platy marls, as distinguished by Peszat (1968), showing dense parallel lamination and easily disintegrating into thin and relatively large plates. In the present paper they are called shaly marls.

The limestones are dark gray in colour with a distinct steel-gray tint. They are very compact, poorly arenaceous, structureless and detrital in character. In the top of their beds, at the contact with shales, black-coloured and clay-rich, parallel or discontinuous cross lamines locally appear.

The marls in the olistoliths in question are dark gray, nearly graphite-black, hard and arenaceous. When weathered they become brown and friable. Calcitic bioclasts, up to $2 \mathrm{~mm}$ in size, are visible in them. Locally, there occur structureless and parallel or crosslaminated varieties. In the olistolith appearing in the eastern part of this quarry, the rocks resembling psammitic blocky marls as described by Peszat (1968) occur, and in the western wall there are psammitic bedded marls. 
TABLE 4

Marls belonging to the Lower Cieszyn Beds (Goleszów Marls) uncovered at the Nowa Marglownia quarry (Goleszów).

\begin{tabular}{llll}
\hline Location & Sample No. & Lithology & Colour \\
\hline east quarry wall (GPS: $\left.49^{\circ} 44^{\prime} 39^{\prime \prime} \mathrm{N}, 18^{\circ} 43^{\prime} 53^{\prime \prime} \mathrm{E}\right)$ & \\
& $\mathrm{GO} / 1$ & shaly marl & black \\
$\mathrm{GO} / 2$ & thin-bedded limestone & dark grey \\
& $\mathrm{GO} / 3$ & shaly marl & beige-black \\
$\mathrm{GO} / 4$ & thin-bedded limestone & dark grey \\
& $\mathrm{GO} / 5$ & shaly marl, calcite-filled cracks & black \\
& $\mathrm{GO} / 6$ & limestone (olistolith) & dark grey \\
& $\mathrm{GO} / 7$ & limestone (olistolith) & dark grey \\
olistolith I & $\mathrm{GO} / 8$ & shaly marls, calcite-filled cracks & black \\
olistolith II & $\mathrm{GO} / 9$ & blocky marl & dark grey \\
& $\mathrm{GO} / 10$ & blocky marl & dark grey \\
& $\mathrm{GO} / 10 \mathrm{a}$ & blocky marl, weathered & brown \\
& $\mathrm{GO} / 11$ & platy limestone & dark grey \\
$\mathrm{GO} / 11 \mathrm{a}$ & limestone-shale transition & black \\
& $\mathrm{GO} / 12$ & platy limestone & steel-grey \\
olistolith III & $\mathrm{GO} / 12 \mathrm{a}$ & limestone-shale transition & black \\
\hline
\end{tabular}

Summary and lithologic classification of marls

According to the present author's studies, in the described fragment of olistostrome exposed in Goleszów only one coloured variety of marls is represented. These are black marls that show variable tints from graphitic to coal-like and beige-black. Taking into account the grain-size distribution, two varieties of these marls can be distinguished, corresponding to those characterized by Peszat (1968): psammitic and aleuritic. Among psammitic marls we observe structureless (massive) and parallel- and cross-laminated varieties. Aleuritic marls are parallel-laminated. Among psammitic marls, blocky and bedded varieties are visible. Aleuritic marls are characterized by platy fissility and are distinguished as shaly marls (Table 4). 


\subsubsection{Upper Cretaceous marls}

\section{Siliceous-Fucoid Marls}

Geological background

The Siliceous and Fucoid Marls (Turonian-Santonian and Campanian-Lower Maastrichtian respectively) are distinguished in the Skole Unit (Table 1; Figs. 1, 2). They begin the sedimentation of the Inceramian Beds (sensu lato) called in the formal subdivision (Table 2) the Ropianka (Kotlarczyk 1978, 1988) or the Rybotycze Formation (Wójcik et al. 1996). The Siliceous (Hołownia) Marls are assigned to the Cisowa Member. The Fucoid (Kropiwnik) Marls are a part of the Wiar Member (Kotlarczyk 1978, 1988). In other lithostratigraphic subdivisions (Bromowicz 1974) the Siliceous-Fucoid Marls are considered to represent the series underlying the Inoceramian Beds (sensu stricto). In some publications the Siliceous and the Fucoid Marls are joined into one complex (e.g. Bieda et al. 1963, Bromowicz 1974) called the Siliceous-Fucoid Marls. Lower and upper boundaries of this complex are diachronous.

The Siliceous Marls are underlain by pelagic sediments, represented predominantly by Barremian-Cenomanian shales, that occur in the whole Outer Carpathians. Initially, sphaerosiderite-bearing black shales were distinguished in the Skole Unit as the Spas Shales Formation and the overlying radiolarite-bearing green and variegated shales as the Dołhe Formation (Kotlarczyk 1978, 1988). Between the latter formation and the Siliceous Marls there occurs a series of shales containing limestone, marls and bentonite intercalations, several tens of meters thick (Bromowicz, Otwinowski 1975).

In the stratotype area (Rybotycze region, eastern part of the Skole unit), between the Siliceous (Hołownia) Marls and the Fucoid (Kropiwnik) Marls, Kotlarczyk (1978, 1988) has distinguished a sandstone-shale complex (Rybnik Flysch). The transition of Siliceous Marls into siliciclastic flysch and of siliciclastic flysch into Fucoid Marls is continuous. In the transition zones, there are thin intercalations of the Tereszów and Kanasin Variegated Shales respectively, indicating more quiet sedimentation.

The Siliceous Marls and the Rybnik Flysch together form the Cisowa Member. The Fucoid (Kropiwnik) Marls are grading gradually upwards into thick complex of thinbedded sandstones and shales, called the Turnica Flysch, corresponding to the Inoceramian Beds (sensu stricto) in the informal subdivision. The Fucoid Marls and the lower part of the Turnica Flysch together form the Wiar Member. In Kotlarczyk's $(1978,1988)$ opinion, the whole Fucoid Marls complex is characteristic of marginal part of the Skole basin.

\section{Previous works}

In the stratotype area, the Siliceous Marls are represented by light gray, thin-bedded, hard marls (calcilutites), calcarenites, sandstones, siltstones and soft, green marls. Their cyclicity is marked by frequent sequence calcilutite-soft marls. In some marly beds fucoids and lenticular cherts occur (Kotlarczyk 1978, 1988). Apart from sponge spicules and radiolaria, the occurrence of agglutinated foraminifers in them is visible (Nowak 1973b; Wieser 1974). In middle part of the marly complex in the Rybotycze outcrop, two bentonite intercalations were found (Koszarski et al. 1962). The Fucoid Marls are lithologically very similar to Siliceous ones, but contain more intercalations of sandstones and soft marls, 
together forming two-element rhythms (Kotlarczyk 1978, 1988). Bioturbations and the activity of currents that occurred during sedimentation of the Hołownia Marls (Siliceous Marls) were described by Leszczyński (2003).

In the middle part of the Skole Unit, Bromowicz (1974) has distinguished three lithological varieties of siliceous-fucoid marls: (1) white-grayish hard, split, (2) very hard of bluish colour that is less common and (3) soft green. All the varieties are thin-bedded and parallel laminated.

The Siliceous-Fucoid Marls were profiled and sampled in the western part of the Skole Unit, in Szczepanowice near Tarnów. This is one of the best outcrops in the Western Carpathians. Its general characteristics were presented by Koszarski (1985a) and Ślączka, Kamiński (1998a). In the Olszawka Szczepanowska Stream a complex of TuronianSenonian calcareous flysch that is about 500 meters thick is exposed, traditionally called the Siliceous Marls. It grades into normal sandy-shaly flysch with thick sandstone beds, representing the Inoceramian Beds (sensu stricto) of Upper Senonian-Palaeocene age. According to Koszarski (1985a) this calcareous flysch that occurs in Szczepanowice corresponds to the Hołownia Siliceous Marls and, at least partly, to the Kropiwnik Fucoid Marls, distinguished by Kotlarczyk $(1978,1988)$ in the stratotype region. The SiliceousFucoid Marls, exposed in the Olszawka Szczepanowska Stream, overlie a thin complex composed mainly of shales (up to $50 \mathrm{~m}$ thick) that are thrust over the Miocene deposits. This complex corresponds to the Spas Shales and the Dothe Formation distinguished by Kotlarczyk $(1978,1988)$ in the stratotype area. According to Koszarski (1985a), distinct dipartite rhythms are visible in the complex of Siliceous-Fucoid Marls. The cycle was initiated by calcilutites, very fine-grained calcarenites and pelagic calcareous-clayey rocks (pelagic turbidites). They are represented by thin (up to $20 \mathrm{~cm}$ ) limestone, marly limestone and often partly silicified hard marl. Locally, they contain lenticular chert. This cycle is closed by soft fucoid marl, marly shale or claystone. In Koszarski's (1985a) opinion, when going upwards in this section, the amount of gray-greenish soft marls increases at the expense of their light gray hard variety.

\section{Results of fieldwork}

\section{Lithologic classification of marls}

Four fragments of the Siliceous-Fucoid Marls complex in the Olszawka Szczepanowska Stream in Szczepanowice near Tarnów were profiled and sampled (Table 5; Fig. 4), in 2001. These outcrops occur in the section more than $1300 \mathrm{~m}$ long. 


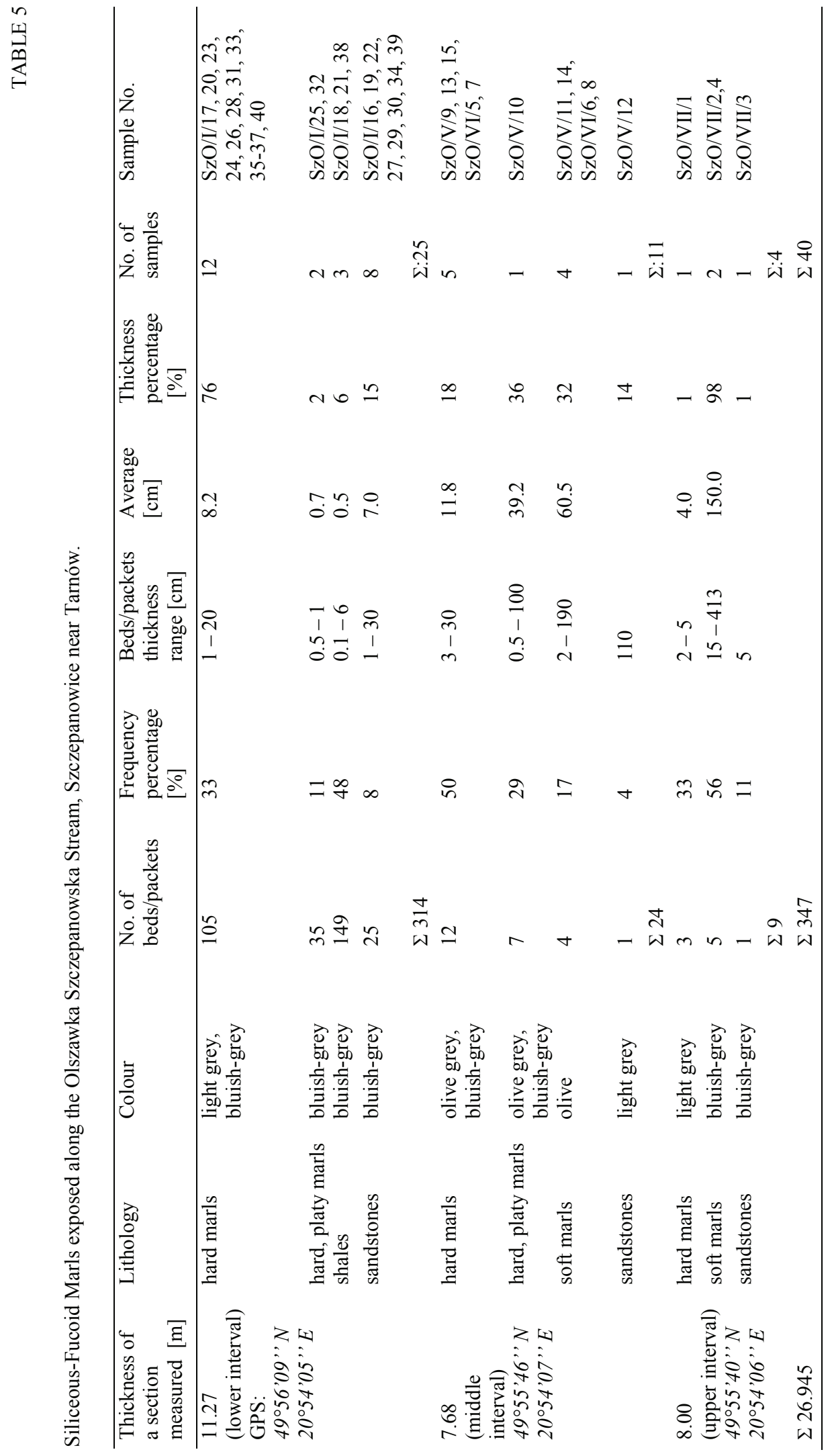




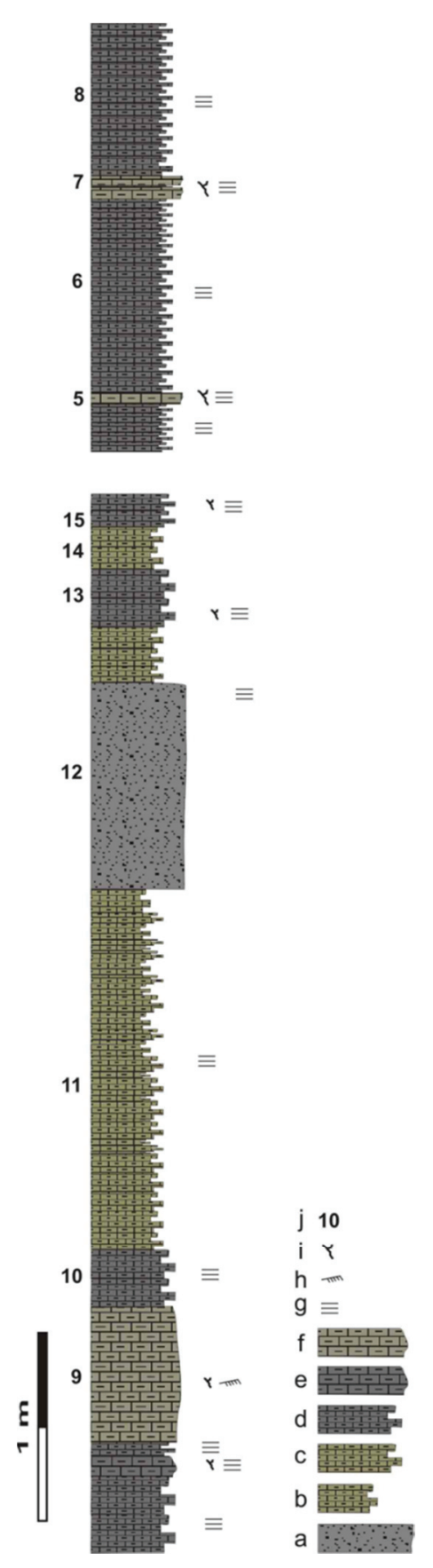

Fig. 4. Lithology of the Siliceous-Fucoid Marls (middle interval of the sequence) exposed along the Olszawka Szczepanowska Stream (Szczepanowice near Tarnów).

Explanations: a - sandstones; $\mathrm{b}$ - soft marls; c-d - hard slabby marls: c - olive-grey; d - bluish-grey; e-f - hard marls: e - bluish-grey, $\mathrm{f}$ - olive-grey; $\mathrm{g}$ - parallel lamination; $\mathrm{h}$ - cross-lamination; $\mathrm{i}$ - fucoids; $\mathrm{j}$ - samples. 
The distinguished hard marls dominate in lower part of this cross-section, whereas the soft ones in its higher part. Hard marls are very thin- and thin-bedded, whilst among the soft ones medium and thick beds are visible as well. The thickness of beds increases upsection. The colour of hard marls is gray of variable tints (light gray, bluish-gray and olive-gray), whereas soft marls are olive and blue-gray. The marls are generally parallel and are rarely cross-laminated. Coarser grains, corresponding to silt- or fine sand-sized material, appear in the bottom of some beds. The beds of hard marls show fine-platy parting or lack of this feature. On the other side, soft marls exhibit flaggy parting. Marls are interbedded with shale and sandstone. In the lower part of the succession, there are composite beds: marl-shale and sandstone-marl couplets, whilst in the upper one, marl- and rarely sandstone beds are visible. 40 samples of rocks from these outcrops were collected for detailed studies, represented by 27 marls, 3 shales and 10 sandstones (Tables 3, 5).

\section{Detailed outcrop descriptions}

The first fragment, representing the lowest part of this profile, is exposed at the distance of $465 \mathrm{~m}$ upstrem from the bridge. The beds dip $25-45^{\circ}$. More than 11 meters of rocks of this section, composed of 314 beds, were profiled (Table 5). They represent mainly light gray and bluish-gray hard marls, composed of beds $0.5-20 \mathrm{~cm}$ thick, interbedded with bluish-gray shale $0.1-6 \mathrm{~cm}$ thick. Locally, hard marls are underlain by sandstone beds $1-$ $30 \mathrm{~cm}$ thick. In the upper part of this outcrop shale-very thin bluish-gray hard marl intercalations appear.

Hard marls are light gray and are less abundantly bluish-gray, very hard, split, irregular, discontinuous parallel-laminated in dark, very thin streaks, locally defined by fine lenses of cherts. At the top, the beds of hard marls show dense, fine-platy parting and the upper contact with shales is gradational. The dominance of marly division in bipartite marl-shale beds is distinct. Fine platy-parting exhibits entire marl beds of bluish-gray variety.

The shales are bluish-gray and calcareous, showing fine fissillity. Usually, the packets of shales contain very thin (less than $1 \mathrm{~cm}$ thick) intercalations of bluish-gray, hard marls.

The sandstones are bluish-gray, fine- to very fine-grained, irregularly laminated. This lamination is locally very dense, parallel in bottom parts and cross in the top one. The laminae are black, containing carbonaceous detritus, mica flakes and clasts of green shales, up to $2 \mathrm{~mm}$ in size. Sandstones are marly and show variable compactness (from welllithified to friable). The bottom surfaces and, locally, the top surfaces are uneven, and the thickness of beds is laterally variable. Bioturbations are visible. Sandstone-marl couplets with dominance of marly division composed by hard marl are frequent, whereby the sand/mud thickness ratios in these beds varies from 0.6 to 0.2 and boundaries are sharp.

Another fragment of this profile is exposed about $500 \mathrm{~m}$ upwards in this stream. At the distance of more than $70 \mathrm{~m}$ on both streambanks, nearly 8 meters (24 beds) of predominantly olive-gray rock can be seen (Fig. 4). Among hard marls, showing platy parting, ranging in bed thickness from $0.5-100 \mathrm{~cm}$, there appear soft marls intercalations, 2-190 cm thick. Some of the hard marls in this outcrop show no parting and occur in packets composed of several thin beds $(3-30 \mathrm{~cm}$ thick), not separated by shales. This variety of marls forms two-element rhythms, either with hard marls showing platy parting or with soft marls. Fucoids are common, particularly in hard marls. Among soft marls there is a light gray sandstone bed, anomalously thick $(110 \mathrm{~cm})$. 
Soft marls are olive green, faintly parallel-laminated, and show flaggy parting. On the surface of parting we observe bioturbations.

Hard marls show platy parting and are bluish-gray and olive-gray. The weathered surfaces are white. This variety of marls exhibits dense, faint parallel lamination marked by change of colour intensity and grain size. Lamines composed of coarser grains appear in the bottom part of beds. On the surfaces of parting fine mica flakes can be observed. In some beds, spots of black chert appear.

Hard marls are bluish-gray and olive-gray. Lamination is locally defined by lenses and streaks of black chert, 1-2 cm thick and up to $3 \mathrm{~cm}$ long. Parallel and, less commonly, cross lamination, defined by coarse grain distribution, is visible only in bottom parts of some beds.

The sandstone is light gray and fine-grained. In its top an indistinct parallel lamination is visible. It is marly and compact.

The highest part of this marly succession represents the fragment of profile situated $250 \mathrm{~m}$ upwards in the stream valley. It is exposed on both streambanks and is about 45 meters long. The thickness of this profile amounts to 8 meters ( 9 beds). This outcrop is dominated by relatively thick beds $(15-413 \mathrm{~cm})$ of reddish weathering bluish gray soft marls, containing thin $(2-5 \mathrm{~cm}$ thick) interbedding of light gray hard marls and less abundant bluish-gray sandstones.

\section{Summary}

According to the present studies, light gray hard marls dominate in the lower part of the profile, followed upwards by olive-gray rocks, composed of soft and hard platy marls in similar proportions and less abundant hard marls. In the uppermost part bluish gray soft marls dominate (Table 5).

In the lowermost part of this complex the frequency of light gray hard marls amounts to $33 \%$, the thickness percentage to $76 \%$ and the average thickness of beds is $8.2 \mathrm{~cm}$, whereas for platy hard marls it is $11 \%, 2 \%$ and $0.7 \mathrm{~cm}$ respectively. The frequency, thickness percentage and average thickness of shale packets amounts to $48 \%, 6 \%$ and $0.5 \mathrm{~cm}$ respectively. The same data for sandstones are as follows: $8 \%, 15 \%$ and $7 \mathrm{~cm}$.

In the higher part (Fig. 4) the frequency of olive gray soft marls amounts to $17 \%$ and thickness percentage $32 \%$, whereas the average thickness of beds $60.5 \mathrm{~cm}$. The frequencies and average thickness of platy hard marls are $29 \%, 36 \%$, and $39,2 \mathrm{~cm}$ respectively, whilst for hard marls it is $50 \%, 18 \%$ and $11.8 \mathrm{~cm}$. For sandstones these frequencies amount to $4 \%$ and $14 \%$ respectively.

In the highest part of this profile the frequency of bluish gray soft marls is $56 \%$, the thickness percentage $98 \%$ and the average thickness of their beds is $150 \mathrm{~cm}$. The frequencies and thickness of beds of hard marls are $33 \%, 1,5 \%$ and $4 \mathrm{~cm}$ respectively. For sandstones these frequencies are $11 \%$ and $1 \%$ respectively.

According to the present studies, the Siliceous-Fucoid Marls in the outcrops examined are represented by hard variety, occurring in very thin and thin beds, whereas the soft variety occur in medium and thick beds as well. Both varieties of marls are distinctly laminated, usually parallel and, less frequently, cross. Some marly beds are underlain by thin layer of sandstone or their deposition was initiated by fine sand-sized grains streak. The beds of hard variety of marls are separated by very thin intercalations of shales, by 
beds of soft marls of different thickness or occur in complexes containing no shales. The Siliceous-Fucoid Marls are generally gray, showing different tints of this colour (light gray, olive-gray, bluish-gray).

\section{Węgierka (Baculite) Marls}

\section{Geological background}

The Węgierka Marls, called the Baculite Marls, (Table 1; Figs. 1,2) occur in the northern, outer part of the Skole Unit within sandy-shaly flysch of the Upper Inoceamian Beds (upper part of the Ropianka Formation). In the formal subdivision (Table 2) the Węgierka Marls are assigned to the Leszczyny Member (Late Maastrichtian - Early Paleocene) of the Ropianka Formation (Kotlarczyk 1978, 1979, 1988). Bromowicz (1974) has distinguished this fragment of profile of the Inoceramian Beds as the complex characterized by the occurrence of the Baculite Marls and thick-bedded sandstones, as well as of clayey conglomerates (complex IV).

The thickness of this fragment of the Inoceramian Beds (upper part of the Turnica Flysch) containing olistostromes and olistoliths of baculite marls (complex IV Bromowicz 1974, the Leszczyny Member of the Ropianka Formation, Kotlarczyk 1978, $1979,1988)$ is about 300 meters. The length of olistoliths is up to 300 meters and their volume reaches several thousand cubic meters.

The lower boundary of the Leszczyny Member (upper part of Late Maastrichtian- lower part of Early Palaeocene) is marked by the appearance of submarine mass movements in the Turnica Flysch (Kotlarczyk 1978, 1979). This corresponds to the top of the Wiar Member (Lower Campanian - lower part of Upper Maastrichtian) from 300-1100 meters thick.

The upper boundary of the Leszczyny Member is designated by the appearance of the carbonate-free flysch, distinguished by Kotlarczyk $(1978,1988)$ as the Wola Korzeniecka Member (upper part of Lower Paleocene - lower part of Upper Paleocene). The thickness of this member decreases from the margin of basin to its axis from 80-30 meters. This is the youngest member of the Ropianka Formation (Bromowicz 1974; Kotlarczyk 1978, 1988), corresponding to the clayey-sandstone complex grading into Eocene Variegated Shales (complex V, in Bromowicz 1974). It is locally overlain by submarine slump deposits (Malata 1996). The Wola Korzeniecka Member in its top part is interpenetrated with variegated shales (Upper Paleocene - Eocene). Their thickness is up to 100 meters.

The Węgierka (Baculite) Marls were profiled and sampled in outcrops localized in marginal part of the Skole Unit, in the outer (Węgierka Village) and inner (Babice Village on San River) zone of their occurrence (Table 6). In Węgierka and Babice 5 olistoliths were profiled and 63 samples collected for laboratory studies (Tables 3, 6). In the opinions of Burzewski (1966) and Geroch et al. (1979), the Baculite Marls from olistoliths in Węgierka are lithologically different from those from olistoliths occurring in Babice. 


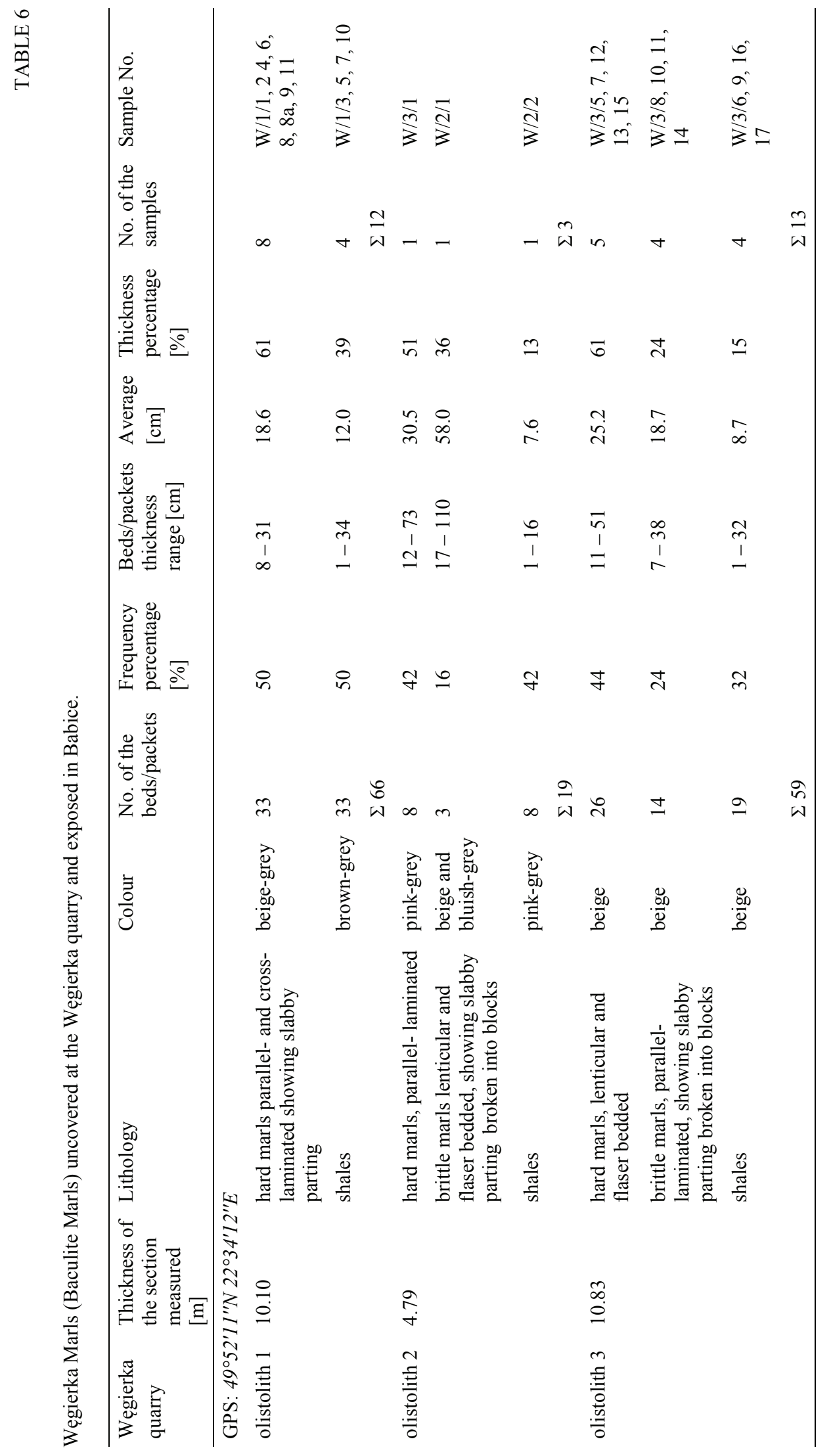




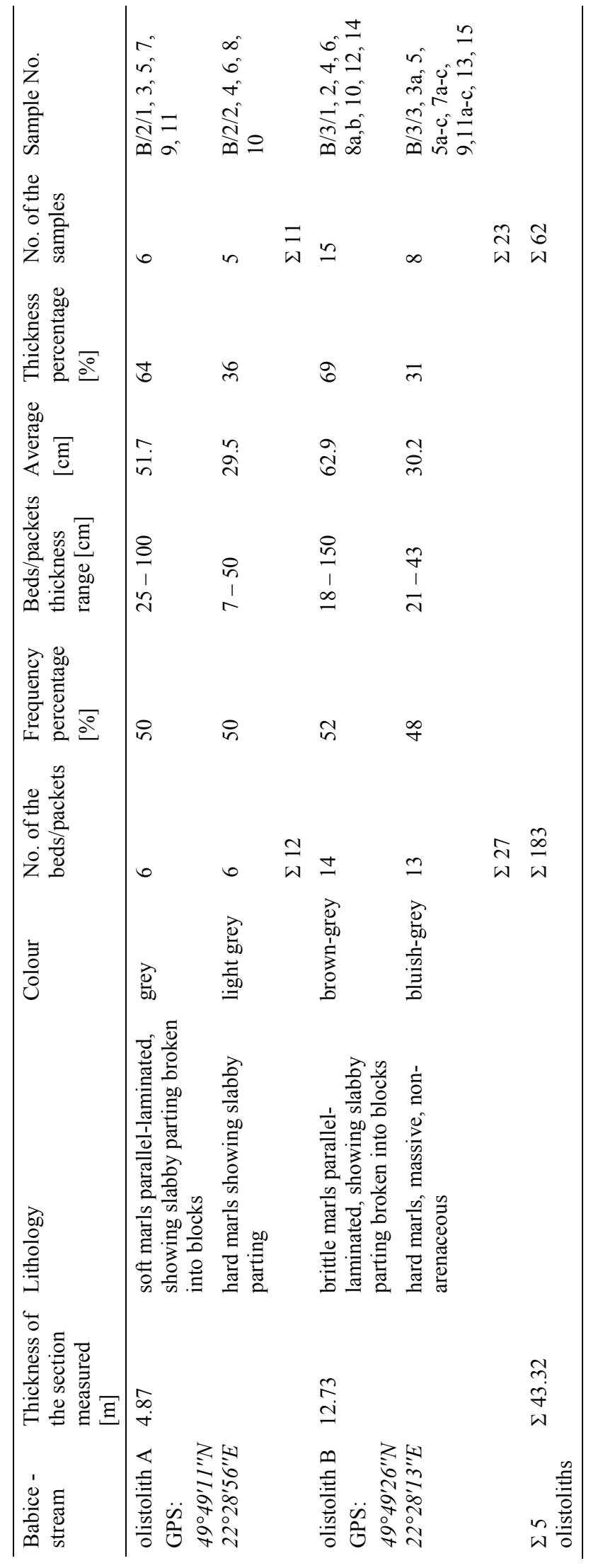




\section{Węgierka quarry}

\section{Previous works}

Olistoliths of the Baculite Marls in Węgierka outcrop in a periodically active quarry on eastern side of the road and the Węgierka Stream. It is the biggest exposure of these marls, considered to be locus typicus. The length of the wall of this quarry is about 100 meters. In Gucik's (1988) opinion, variable orientation of beds in this outcrop is due to the presence of three olistoliths in this quarry. The fourth olistolith is localized by this author in adjacent wood.

According to Geroch et al. (1979) the Baculite Marls in the Weqgierka quarry are arenaceous, laminated, containing carbonaceous detritus and muscovite, which have been found on parting surfaces. Their beds are $15-50 \mathrm{~cm}$ thick. The boundaries of beds are sharp and some interlayers of shales can be observed that are several millimeters thick. Straight asymmetric ripplemarks on bed top and trace fossils, represented by Rhizocorallum, occur on the on bed base.

In Gucik's (1988) opinion, the Baculite Marls occurring in different olistoliths are lithologically different. In the lower complex of the SW part of this quarry (olistolith 1) they are brownish gray, thin-platy, finely laminated and disintegrate into thin brittle plates. At the surfaces of these plates there are carbonaceous detritus and mica flakes. In the middle part (olistolith 2), the marls are more compact and the lamination is visible only at weathered surfaces. On the other side, marls that occur in the $\mathrm{N}$ part of this quarry (olistolith 3 ) are characterized by thick beds, 0.5 to 1.5 meters thick.

\section{$\underline{\text { Results of fieldwork }}$}

\section{Lithologic classification of marls}

In 1994-95 the marls in the three olistoliths in the Weqgierka quarry were profiled and sampled. They all are arenaceous and of the same beige colour with a gray, pink, or bluish tint. The beds are generally thin (about $20 \mathrm{~cm}$ ). Hard and brittle marls were distinguished. Among both these varieties various type of lamination can be seen: parallel, cross, lenticular and flaser. Bioturbations are common. The beds of all these varieties exhibit slabby parting, whereby slabby parting broken into blocks is visible only in their brittle variety and marls massive, lack parting, appear among their varieties showing lenticular and flaser bedding.

\section{Detailed outcrop descriptions}

According to the present studies, in the SW part of the quarry (olistolith 1) there are beds of hard marls showing parallel and cross lamination and distinct slabby parting, grading upwards into shales. In the remaining two olistoliths, apart from parallel laminated marls, there is another variety that shows lenticular and flaser bedding. In middle part of this quarry (olistolith 2) the first mentioned marl represents their hard variety, the second the brittle one, whereas in the northern part (olistolith 3) the relation is reversed. The thickest beds, reaching $110 \mathrm{~cm}$, are visible in middle part of this quarry (olistolith 2).

In SW part of this quarry (olistolith 1) 66 beds of marls intercalated with shales of total thickness more than 10 meters were profiled (Table 6). The beds are dipping steeply to the NE (48/85). The marls are very hard, usually parallel laminated, showing distinct platy 
parting (2-3 cm thick), beige-gray in colour and arenaceous. On the parting surfaces, mica flakes and dark brown vegetal detritus are visible, as well as local calcitic impregnation. Weathered portions of beds present in the wall of the quarry are uneven, nodular. The bottoms of marly beds are sharp and toward the top they grade into shales. Shales are brownish-gray, calcareous, arenaceous, brittle, fairly soft, thin-platy (about $2 \mathrm{~mm}$ thick), occasionally showing platy parting broken into blocks. The average thickness of marl beds amounts to $18.6 \mathrm{~cm}$ and ranges between 8 and $31 \mathrm{~cm}$, whilst that of shales $12 \mathrm{~cm}$ and ranges from $1-34 \mathrm{~cm}$. The thickness percentage of marls in this profiled olistolith amounts to $61 \%$ whilst that of shales is $39 \%$.

In the middle part of this quarry (olistolith 2) 19 beds with a total thickness of about 5 meters were profiled (Table 6). Two lithologic varieties of marls and shaly intercalations occur in this olistolith.

The most common (frequency percentage 42\%) are beige-gray marls with rosa tint, hard, poorly arenaceous, parallel laminated, showing locally indistinct marked platy parting. On the parting surfaces the bioturbation, dark brown organic detritus and mica flakes are visible. This variety of marls is impregnated with calcite, forming irregular streaks, up to $10 \mathrm{~cm}$ long and $2-3 \mathrm{~cm}$ thick. Individual calcite crystals, about $0.5 \mathrm{~cm}$ in size, are also present. The beds of these marls are, on average, $30.5 \mathrm{~cm}$ thick and varying from 12 to $72 \mathrm{~cm}$. Their thickness percentage in the profiled olistolith amounts to $51 \%$.

Less common (frequency percentage 16\%) are beige, locally bluish marls, fairly hard and arenaceous, showing lenticular and flaser bedding and distinct platy parting or platy parting broken into blocks $(2-3 \mathrm{~cm}$ in size). At the surfaces of some beds ripplemarks are visible. The thickness of these marls varies from 17 to $110 \mathrm{~cm}$ and are, on average, $58 \mathrm{~cm}$. Their thickness percentage amounts to $36 \%$.

The shales are beige-gray with pinkish tint, soft, arenaceous finely parting and calcareous. Their frequency percentage amounts to $42 \%$ and the thickness percentage is $13 \%$. The thickness of beds are, on average, $7.6 \mathrm{~cm}$ and varies from $1-16 \mathrm{~cm}$.

In the NE part of this quarry (olistolith 3) 59 beds were distinguished, representing two lithologic varieties of marls and shales, with a total thickness of about 11 meters (Table 6; Fig. 5). Contrary to the two above described olistoliths, the beds in this one are dipping steeply to the SW (210/72). 


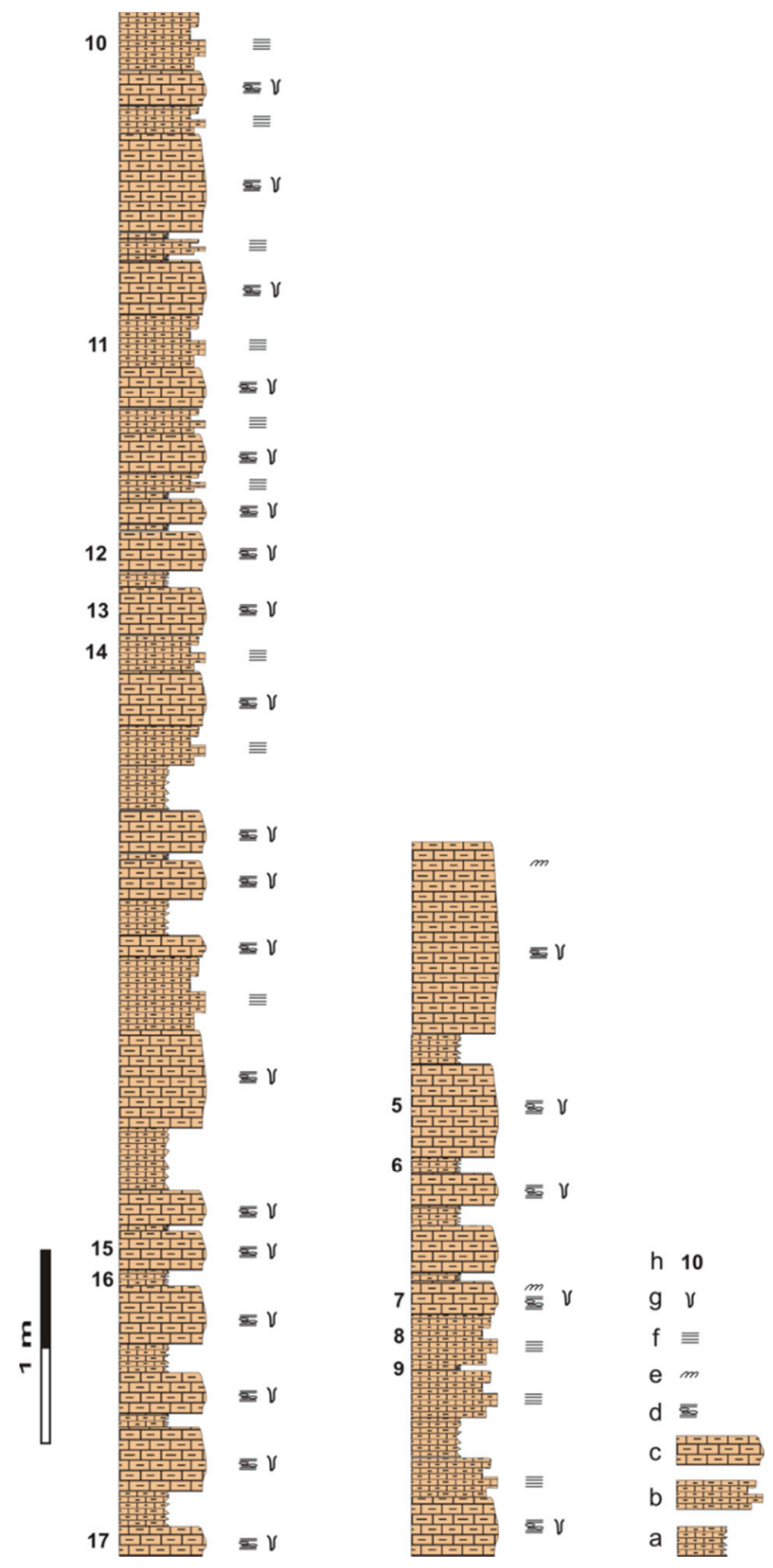

Fig. 5. Lithology of the Węgierka Marls (Baculite Marls) uncovered at the Węgierka quarry (olistolith 3). Explanation: $\mathrm{a}$ - shales; $\mathrm{b}$ - brittle marls showing slabby parting broken into blocks; hard marls massive; $\mathrm{d}$ - lenticular and flaser bedding; e - ripplemarks; $\mathrm{f}$ - parallel lamination; $\mathrm{g}$ - burrows; $\mathrm{h}$ - samples. 
The most common (frequency percentage 44\%) are hard, arenaceous, beige marls, showing lenticular and flaser bedding. Bioturbations and ripplemarks are present on the surfaces of beds. This variety of marls are impregnated with calcite, forming irregular spots. Lamination is more dense in the top parts of beds. The thickness of beds varies from 11 to $51 \mathrm{~cm}$ (on average $25.2 \mathrm{~cm}$ ). Thickness percentage of this variety of marls amounts to $61 \%$.

Less abundant (frequency percentage 24\%) are beige, parallel laminated, arenaceous, brittle marls, showing platy parting and platy parting broken into blocks marked every 1 to $2 \mathrm{~cm}$. The platy parting broken into blocks dominates, usually in bottom parts of beds and the platy one in the top. This variety of marls easily degrade to mud in water. When weathered it becomes friable. The thickness of beds varies in the range 7-38 cm (on average $18.7 \mathrm{~cm}$ ). The thickness percentage of this variety of marls amounts to $24 \%$.

The shales are arenaceous, beige, showing fine platy parting. Their frequency percentage amounts to $32 \%$ and the thickness one $15 \%$. The thickness of beds varies from $1-32 \mathrm{~cm}$ (on average $8.7 \mathrm{~cm}$ ).

In the olistolith 3, marls showing lenticular and flaser bedding are overlain by parallel laminated marls and followed by shales, or both varieties of marls are overlain by shales directly.

\section{Babice area}

\section{Previous works}

According to Geroch et al. (1979), in Babice the olistoliths are composed of alternating arenaceous, flaggy parting, laminated marls, consisting of beds $10-40 \mathrm{~cm}$ thick, and silty, shaly, fissile parting, structureless marls, composed of beds from 30-100 cm thick. Both of these varieties of marls contain muscovite flakes. The boundaries between beds are not sharp.

\section{$\underline{\text { Results of fieldwork }}$}

\section{Lithologic classification of marls}

In 1994, in the outcrops occurring in left tributaries of the San River in Babice, two olistoliths (A and B) of the Baculite Marls and a submarine slump containing blocks of marls were investigated and profiled (Tables 3,6). Arenaceous and nonarenaceous marls were distinguished. Arenaceous marls are gray with brown-pinkish and blue tint. Hard, brittle and soft varieties were distinguished within arenaceous marls. Their beds are both structureless and show parallel lamination. Bioturbations are fairly common. Based on different partings, platy parting broken into blocks, slabby parting and showing no parting (massive) marls were distinguished. Nonarenaceous marls represent hard, structureless massive variety of gray colouration with bluish tint.

\section{Detailed outcrop descriptions}

According to the present author's investigations, the first of the olistoliths studied (olistolith A) is composed of soft and hard varieties of arenaceous marls. In the second (olistolith B) apart from brittle arenaceous marls there are nonarenaceous varieties. The 
thickness of marl beds in both olistoliths is medium, on average; about $60 \mathrm{~cm}$ for marls that show parting and about $30 \mathrm{~cm}$ for the massive one (Table 6).

Olistolith A is exposed in two banks of a left-hand tributary stream of the San River, flowing through Babice. Its outcrop is situated $130 \mathrm{~m}$ from the place where the stream crosses the road to Przemyśl. It is $25 \mathrm{~m}$ long and more than $2 \mathrm{~m}$ high. The beds dip fairly steeply to the SW (190/40). About 5 meters of this olistolith were profiled, comprising two interbedding lithological varieties of marls (Table 6).

The first of them is represented by arenaceous, parallel laminated gray marls, fairly soft, showing platy parting broken into blocks and with locally slabby parting. They are bleached nearly white on weathered surfaces, though broken pieces show that the fresh rock has a subtle light bluish-gray hue. In this variety yellowish, lenticular burrows occur. The thickness of beds is on average $51.7 \mathrm{~cm}$ and varies from $25-100 \mathrm{~cm}$. Their thickness percentage amounts to $64 \%$.

The second variety is represented by platy, arenaceous, very hard marls, with trace fossils on the surfaces of beds and often showing uneven top. They are light gray in colour and whitish when weathered. The thickness of beds is on average $29.5 \mathrm{~cm}$ and ranges from $7-50 \mathrm{~cm}$. The thickness percentage of platy marls amounts to $36 \%$.

Olistolith B is exposed in left-hand tributary of San River, where it flows through Babice. Its outcrop is situated 60 meters from the crossing of field road directed before the church toward the NW to the high road to Przemyśl with a path directed to the north toward the nearest hill. It is $20 \mathrm{~m}$ long and about $5 \mathrm{~m}$ high. Four fragments of cross-section of this olistoliths are exposed. Their total thickness amounts to about 13 meters (Table 6). The beds dip fairly steeply to the SW (210/43). This olistolith consists of two varieties of marls.

More abundant $(69 \%)$ are the brown-gray, brittle marls with pinkish to bluish tint, irregularly, parallel laminated by arenaceous brown-pinkish and clayey bluish-gray, fine, millimeter-sized stringers. The marls show platy parting broken into blocks. On the parting surfaces we observe dark brown organic detritus and mica flakes. These marls are microporous. The thickness of beds is on average $62.9 \mathrm{~cm}$ and varies from $18-150 \mathrm{~cm}$. They contain lenticular, very hard gray-bluish nodular structures, $20-30 \mathrm{~cm}$ thick and 50$70 \mathrm{~cm}$ long, but sometimes is up to 3 meters.

Less abundant ( $31 \%$ of total thickness) are the gray-bluish, very hard, split, structureless, nonarenaceous marls. The thickness of their beds varies from 21 to $43 \mathrm{~cm}$ (on average $30.2 \mathrm{~cm}$ ) (Table 6).

A submarine slump occurs in the escarpment of a path parallel to the banks of the stream above the outcrop of the olistolith II. This slump's deposits consists of gray, easily disintegrated thick-bedded sandstones, that contain blocks of gray, arenaceous marls that are a dozen centimeters thick.

\section{Summary}

According to the present author's investigations, the Baculite Marls, occurring in the five examined olistoliths, differ in colour (variable tints of beige), thickness of beds, hardness, presence of sand-sized grains, parting and beds internal structures. However, it can be stated that the sampled blocks are composed mainly of thin and medium beds of laminated hard and brittle marls, showing platy parting broken into blocks and platy parting, that belongs to arenaceous variety. These marls are light, beige in colour and, on 
average, their beds are thicker and have a deeper gray tint in Babice than of those that occur in Węgierka. Also, the blocks of marls in Babice are smaller and the marls that form them are more lithologically diversified than those in Węgierka (Table 6).

\section{Węglówka Marls}

Geological background and previous works

The Węglówka Marls (Table 1; Figs. 1, 2), occur in the Sub-Silesian Unit, locally in Fore-Magura Scale, in the eastern part of the Silesian Unit and in the inner part of the Skole Unit (Książkiewicz 1962, Bieda 1963). They are upper Cretaceous in age and are particularly developed in the Sub-Silesian Unit. In the formal classification they are distinguished as a formation (Wójcik et al. 1996). According to Olszewska (1997) the Weglówka Formation consists of sediments of Santonian-Bartonian age (higher Upper Cretaceous - Uppermost Middle Eocene). Based on nannoplankton data JugowiecNazarkiewicz (2007) state that in the eastern part of the Polish Carpathians the Węglówka Marls are Early Campanian up to the uppermost part of the Maastrichtian in age, whilst in the western one they represent Early Campanian up to the Early Maastrichtian. In the stratotype area (Węglówka Tectonic Half-Window) the Węglówka Marls are considered to be Upper Cretaceous in age (Santonian to Maastrichtian: Huss 1966, vide Ślączka, Kamiński 1998b, or Campanian to Maastrichtian: Gasiński et al. 1999).

The thickness of the Węglówka Marls is difficult to establish due to tectonic deformations, but is considered to be 200-300 meters (Bieda et al. 1963; Koszarski, Ślączka 1973). They are described as marls and marly shales that are celadon-green, grayish-green, red, pink, occasionally whitish in colour, commonly soft and containing no sandstone intercalations (Bieda et al., 1963). On the other side, they contain phosphorite concretions (Jasionowicz et al., 1959), identified and investigated in detail by Narębski (1960). The lower and upper boundaries of the Węglówka Marls are diachronous (Bieda et al., 1963; Koszarski, Ślączka 1973).

The Węglówka Marls are underlain by Cenomanian to Turonian (locally Lower Senonian) Variegated Shales, up to 60 meters thick, grading continuously into marls.

The Węglówka marls, grading into the Variegated Shales or the Hieroglyphic Beds (upper Middle and lower Upper Eocene), are overlain by Upper Eocene Green Shales, up to $40 \mathrm{~m}$ thick (Bieda et al., 1963).

\section{Results of fieldwork}

The Węglówka Marls were profiled and sampled in the stratotype area in the Węglówka Tectonic Half-Window (Tables 1, 7; Fig. 2). In the Weglówka Village near Krosno there is a nearly continuous outcrop of these sediments, but the condition of the exposures depends on the weather. In 1999-2000 these marls were exposed along the Rzeszów - Krosno roadcut (Fig. 6; Fig. 7 - Point I) as well as in the right tributary (Fig. 7 - Point IIa) and in the stream bed and banks of the Czarny Potok Stream (Fig. 7 - Point IIb), flowing along this road. 
Węglówka Marls exposed in the Węglówka Tectonic Window region.

\begin{tabular}{|c|c|c|c|}
\hline $\begin{array}{l}\text { Outcrops } \\
\text { (meters long) }\end{array}$ & Sampling & Sample No. & Colour \\
\hline$\underline{\text { Point I }}$ & GPS: $49^{\circ} 45^{\prime} 54^{\prime \prime} N$ & & \\
\hline \multirow{2}{*}{$\begin{array}{l}\text { roadcut Rzeszów-Krosno at the } \\
\text { cross-roads in Węglówka Village }\end{array}$} & $21^{\circ} 47^{\prime} 57^{\prime \prime} E$ & & \\
\hline & $\begin{array}{l}\text { distance from the Czarny } \\
\text { Potok Stream }[\mathrm{m}]\end{array}$ & & \\
\hline$(2.0 \mathrm{~m})$ & 7.6 & $\mathrm{WL} / \mathrm{I} / 3$ & variegated \\
\hline$(1.5 \mathrm{~m})$ & 6.0 & WL/I 2 & green \\
\hline$(0.5 \mathrm{~m}+0.1 \mathrm{~m})$ & $5.0-4.95$ & $\mathrm{WL} / \mathrm{I} / 1$ & $\begin{array}{l}\text { variegated and } \\
\text { pink }\end{array}$ \\
\hline$(0.3 \mathrm{~m})$ & 4.75 & & green \\
\hline$(2.0 \mathrm{~m})$ & 3.75 & $\mathrm{WL} / \mathrm{I} / 6$ & variegated \\
\hline$(0.2 \mathrm{~m})$ & 2,9 & $\mathrm{WL} / \mathrm{I} / 5$ & pink \\
\hline \multirow[t]{2}{*}{$(1.5 \mathrm{~m})$} & 1,3 & $\mathrm{WL} / \mathrm{I} / 4$ & green \\
\hline & 1,3 & WSY-1 & $\begin{array}{l}\text { beige (concretion } \\
11 \times 6 \mathrm{~cm})\end{array}$ \\
\hline$\underline{\text { Point IIa }}$ & distance from the tributary & & \\
\hline \multirow{3}{*}{$\begin{array}{l}\text { left tributary of the Czarny Potok } \\
\text { Stream: distance } 94 \mathrm{~m} \text { from the } \\
\text { road Rzeszów-Krosno } \\
(26 \mathrm{~m})\end{array}$} & $\begin{array}{l}\text { outlet }[\mathrm{m}] \\
\text { outlet: } 49^{\circ} 45^{\prime} 51^{\prime \prime} \mathrm{N} \\
21^{\circ} 47^{\prime} 56^{\prime \prime} \mathrm{E}\end{array}$ & $\mathrm{WL} / \mathrm{II} / 1$ & green \\
\hline & 20 & $\mathrm{WL} / \mathrm{II} / 2$ & variegated \\
\hline & 25 & $\mathrm{WL} / \mathrm{II} / 3$ & red \\
\hline$\underline{\text { Point IIb }}$ & distance from the bridge $[\mathrm{m}]$ & & \\
\hline \multirow[t]{2}{*}{ section $1(4 \mathrm{~m})$} & $\begin{array}{l}\text { at the bridge: } 49^{\circ} 45^{\prime} 50^{\prime \prime} N \\
21^{\circ} 47^{\prime} 54^{\prime \prime} E\end{array}$ & $\mathrm{WL} / \mathrm{II} / 4$ & red \\
\hline & 2 & $\mathrm{WL} / \mathrm{II} / 5$ & green \\
\hline \multirow[t]{3}{*}{ section $2(6 \mathrm{~m})$} & 19 & $\mathrm{WL} / \mathrm{II} / 6$ & pink \\
\hline & 25 & $\mathrm{WL} / \mathrm{II} / 7$ & red \\
\hline & 35 & $\mathrm{WL} / \mathrm{II} / 8$ & brown \\
\hline \multirow[t]{4}{*}{ section $3(23 \mathrm{~m})$} & 43 & $\mathrm{WL} / \mathrm{II} / 9$ & whitish-green \\
\hline & 49 & $\mathrm{WL} / \mathrm{II} / 10$ & brown \\
\hline & 53 & WL/II/11 & whitish-green \\
\hline & 56 & $\mathrm{WL} / \mathrm{II} / 12$ & whitish-green \\
\hline \multirow[t]{2}{*}{ section 4 (10 m high) } & 86 & $\mathrm{WL} / \mathrm{II} / 13$ & red \\
\hline & 101 & WLF-2 & $\begin{array}{l}\text { beige (concretion } \\
25 \times 5 \mathrm{~cm})\end{array}$ \\
\hline
\end{tabular}




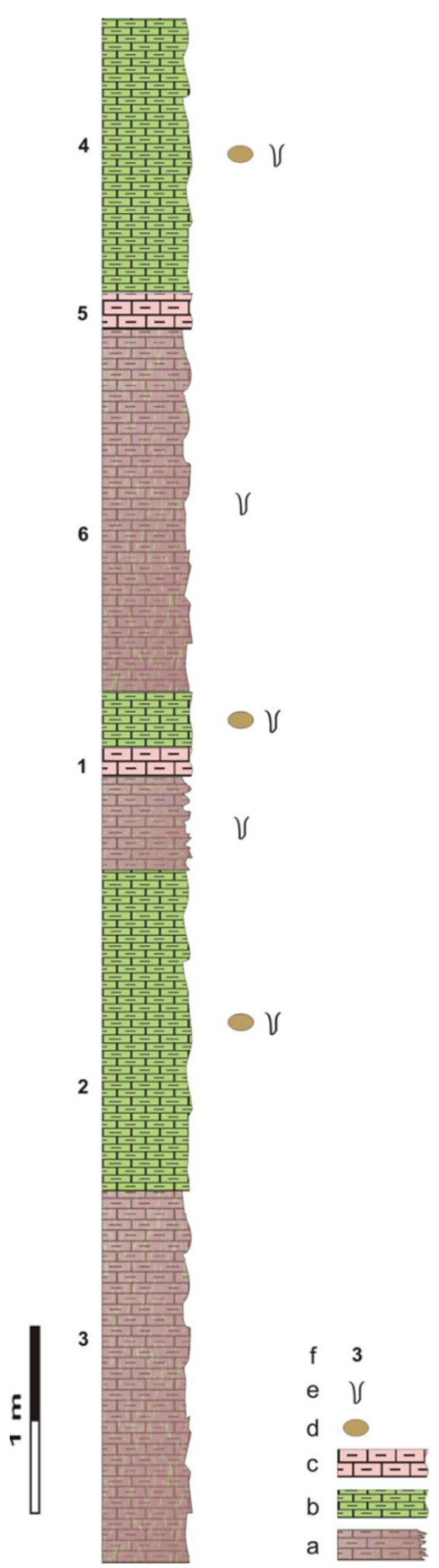

Fig. 6. Lithology of the Węglówka Marls exposed along the roadcut Rzeszów-Krosno at the road cross in the Węglówka Village (Point I). For the location of outcrop see Fig. 7).

Explanation: $\mathrm{a}$ - variegated marls; $\mathrm{b}$ - green marls; $\mathrm{c}$ - pink marls; $\mathrm{d}$ - phosphorite concretions; e-burrows; f-samples. 


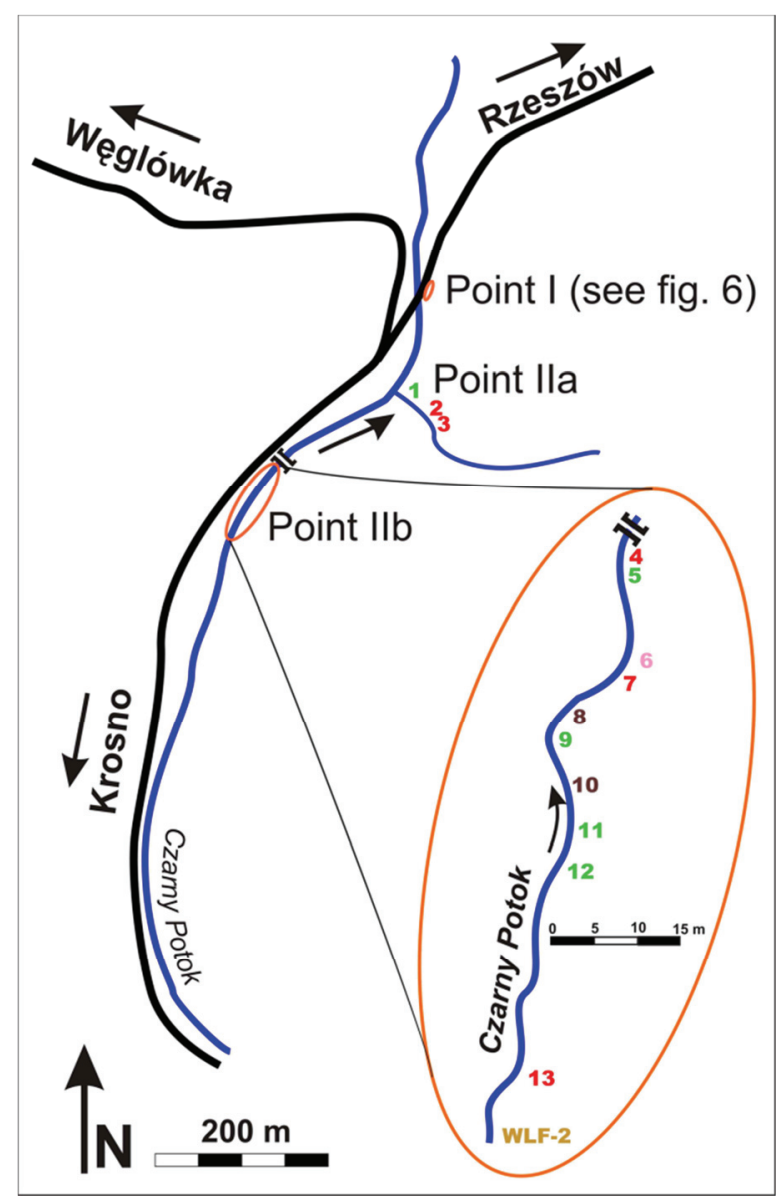

Fig. 7. Location maps of the Węglówka Marls sampled in the Węglówka Village along the Czarny Potok Stream and its left tributary. The colour of sample numbers refers in general to the colour of marls. Samples are listed in the Table 7.

\section{Lithologic classification of marls}

The following varieties of these marls were distinguished: soft, nonarenaceous, massive, bioturbated, non-fissile (massive) and slabby parting, occurring in two different colours: red and green. The distribution of colours, both red and green, is mottled. They show different tints: red marls are cherry-red, brown-red and pink, whilst green marls are grassgreen and pale, whitish-green in colour. Red, mottled variety having green patches was called variegated. Green patches in red marls appear around accumulations of organic matter, filling fine, millimeter-sized burrows. In some marly beds there are hard, ellipsoidal phosphorite concretions, up to $25 \mathrm{~cm}$ long and $6 \mathrm{~cm}$ thick. Nineteen samples, representing different varieties of marls and two of phosphorite concretions were collected for detailed investigations (Tables 3, 6; Figs. 6, 7). 


\section{Detailed outcrop descriptions}

In the slope on the eastern side of the Rzeszów-Krosno road, at the crossing to the Węglówka Village on the stretch of $30 \mathrm{~m}$ from the place where a stream is flowing under the road, we observe an outcrop of red and green marls (Fig. 7 - Point I), dipping steeply to the SE (170/80). More than 9 meters of this cross-section was profiled, composed of 8 medium and thick beds $(0.2-2.0 \mathrm{~m})$ of fairly soft red marls of variegated and pink variety and of greenish marls, whereby the pinkish variety appears in the top of variegated marls (Fig. 6). In this outcrop the marls are massive, non laminated, slabby parting, showing hackly, conchoidal fracture, locally with black stains on the parting surface. In the green marls, individual phosphorite concretions occur. These concretions are loaf-shaped, beige and ginger on the surface. They are up to $11 \mathrm{~cm}$ long and $6 \mathrm{~cm}$ thick (Table 7; Fig. 6).

In the right tributary and in the valley of the Czarny Potok Stream, the marls outcrop at the crossing with the road to Węglówka. One outcrop with 3 beds of red and green marls in the tributary (Fig. 7 - Point IIa) and four exposures with 10 beds in the Czarny Potok Stream channel (Fig. 7 - Point IIb) were profiled and sampled (Table 7).

In the tributary, located $94 \mathrm{~m}$ from the place where the Czarny Potok Stream flows under the road (Fig. 7 - Point IIa; Table 7), the length of outcrop is 26 meters and green and red marls are fairly hard, massive, non-fissile. They form steps in the stream channel. The green variety is grass-green, the red one is mottled (variegated) and cherry-red in colour.

In the valley of the Czarny Potok Stream the almost continuous outcrop is more than 100 meters long and has four sections (Table 7; Fig. 7). Three of them are 33 meters long and consist of 9 alternating beds of red and green marls (Table 7; Fig, 7 - section 1-3; sample No: 4-12). In the first section, at the bridge, the red variety is cherry-red and pink, whilst the green one is grass-green in colour. Upstream, in the second section, only cherryred and pink marls occur. In the third section, the brown-red and pale, whitish-green coloured marls appear. Slabby parting is visible in the streambank outcrops of both red and green coloured varieties of marls but this feature disappears within the stream channel. At the distance about $30 \mathrm{~m}$, in the fourth section occurring in the escarpment, 20 meters high, the red marls are gently dipping towards the south-west (146/26 SE). The marls are cherryred and have slabby parting. Fairly big, flat phosphorite concretions, up to $25 \mathrm{~cm}$ long and up to $5 \mathrm{~cm}$ thick, are also present here.

The grain size of the Węglówka marls corresponds to silty and clayey fractions. The content of fine sand-sized grains is negligible (about $0.3 \%$ ), as estimated in the samples representing both red and green varieties (WI/II/4 and WI/II/5 respectively, Table 7; Fig. 7 ). On the other side, the content of silt-sized grains (only noncalcareous) is about $17 \%$.

Summary

According to the present studies, the marls profiled in Węglówka are represented by interbedding red and green varieties. Both of these types of marls occur in medium and thick beds (often up to 2 meters thick), are nonarenaceous, soft, abounding in burrows rending difficult the identification of beds internal structures and contain phosphorite concretions. It is worth adding, that in the upper part of some marl beds a vertical change in hue, saturation and brightness of colour are visible (Fig. 6). 


\section{Frydek Marls}

\section{Geological background and previous works}

The Frydek Marls (exotic pebbles-bearing gray marls) (Table 1; Figs. 1, 2) occur in the Sub-Silesian Unit (Bieda et al. 1963). They are equivalent to the Węglówka Variegated Marls in western part of this unit. In the Polish Western Carpathians they appear locally, mainly in the Żegocina Tectonic Zone and in Wiśniowa, Żywiec and Goleszów Tectonic Windows (Bieda et al. 1963; Skoczylas-Ciszewska 1960). Upper Senonian Frydek Marls (in Cieszyn Silesia Upper Senonian-Paleocene in age) (Bieda et al. 1963) are distinguished as formation (Wójcik et al. 1996).

The thickness of the Frydek Marls is difficult to establish, since their outcrops occur in tectonically deformed zones. It probably amounts to several tens of meters and does not exceed $100 \mathrm{~m}$ (Bieda et al. 1963). They are described as soft, gray, often arenaceous marls, containing sandstone intercalations. Sandstones are gray, thin-bedded, usually fine-grained, locally curvocortical, micaceous, fairly well-lithified and calcareous. Marls contain exotic material of different size. They are represented by gneiss and granite boulders that are up to several meters in size. Smaller are limestone exotic pebbles. Moreover, blocks of volcanic rocks (andesite) also occur in the Frydek Marls (Skoczylas-Ciszewska 1960; Bieda et al. 1963; Koszarski 1985c; Ślączka 1998).

The Frydek Marls were profiled and sampled in the Żegocina Tectonic Zone. Located near the Kamionna Village the outcrops are along the Pluskawka Stream valley. The marls that occur here were also called Frydek-type Marls to emphasize their similarity in lithology and microfaunistic assemblage with the marls of Frydek facies in the stratotype area near the Frydek Town in the Czech Republic (Książkiewicz, Liszkowa 1959; Skoczylas-Ciszewska 1960). The Żegocina Tectonic Zone is characterized by very complicated geology caused by multi-phase tectonic deformations (strong folding and faulting) (e.g. Skoczylas-Ciszewska 1960; Koszarski 1985c; Jugowiec-Nazarkiewicz, Jankowski 2001). There are folded together series of the Sub-Silesian, Silesian and Skole units. In Skoczylas-Ciszewska's (1960) opinion, marls from the Pluskawka valley belong to the Sub-Silesian Unit and contain nearly exclusively calcareous planctonic foraminifers, indicating their Lower Campanian-Maastrichtian age, and are up to $100 \mathrm{~m}$ thick. The Campanian - Late Maastrichtian age of these marls is also reported by Gasiński et al. (1999), and upper part of the Upper Campanian up to the Uppermost Maastrichtian is indicated by Jugowiec-Nazarkiewicz (2007). According to Koszarski (1985c) they are deformed by submarine slumps and belong to the Silesian Unit. In the opinion of Ślaczka and Kamiński (1998c), the Frydek-type Marls belong to the Skole Unit.

\section{Results of fieldwork}

The Frydek-type Marls in the Żegocina Tectonic Zone are exposed below the unfinished bridge of the Kamionna-Rybie road over the Pluskawka Stream. This outcrop was first described by Skoczylas-Ciszewska (1960). In 2000, three outcrops of the Frydek Marls were recorded here. They were profiled and sampled along $15 \mathrm{~m}$ of this crosssection. Three samples of marls and one of sandstone were collected for detailed investigations (Tables 3,8 ). 


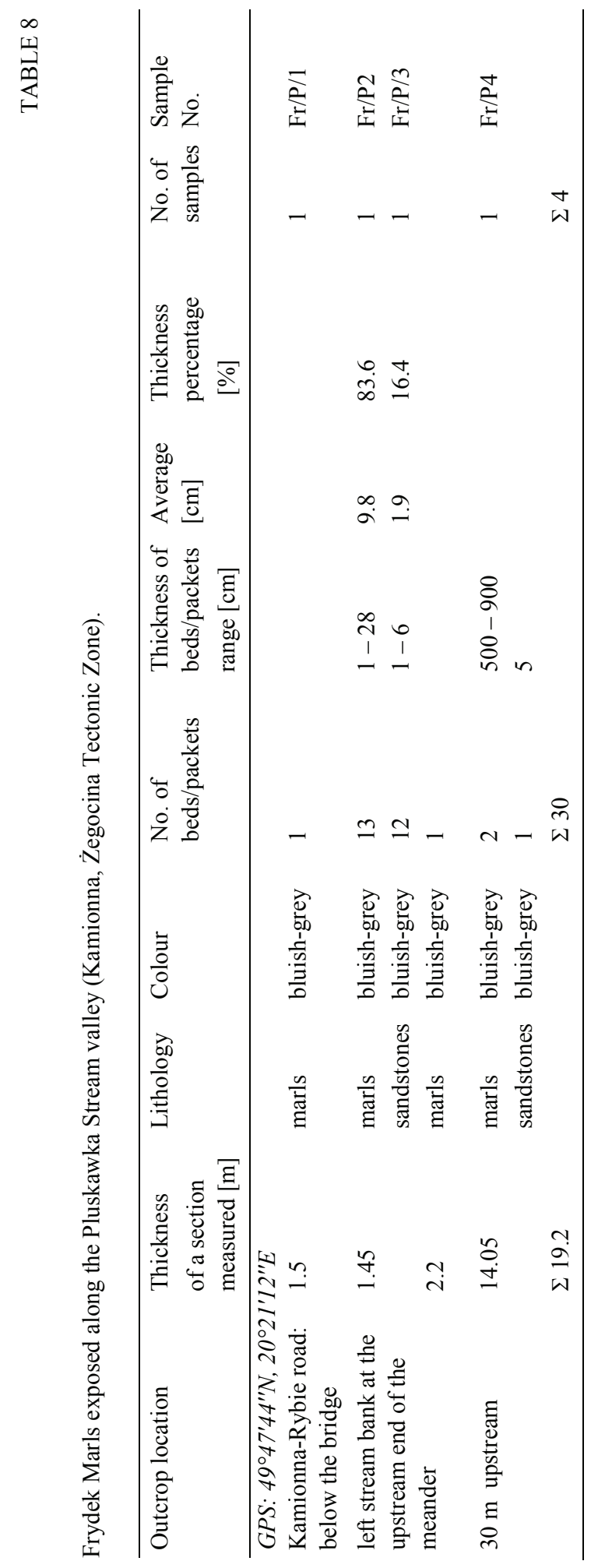




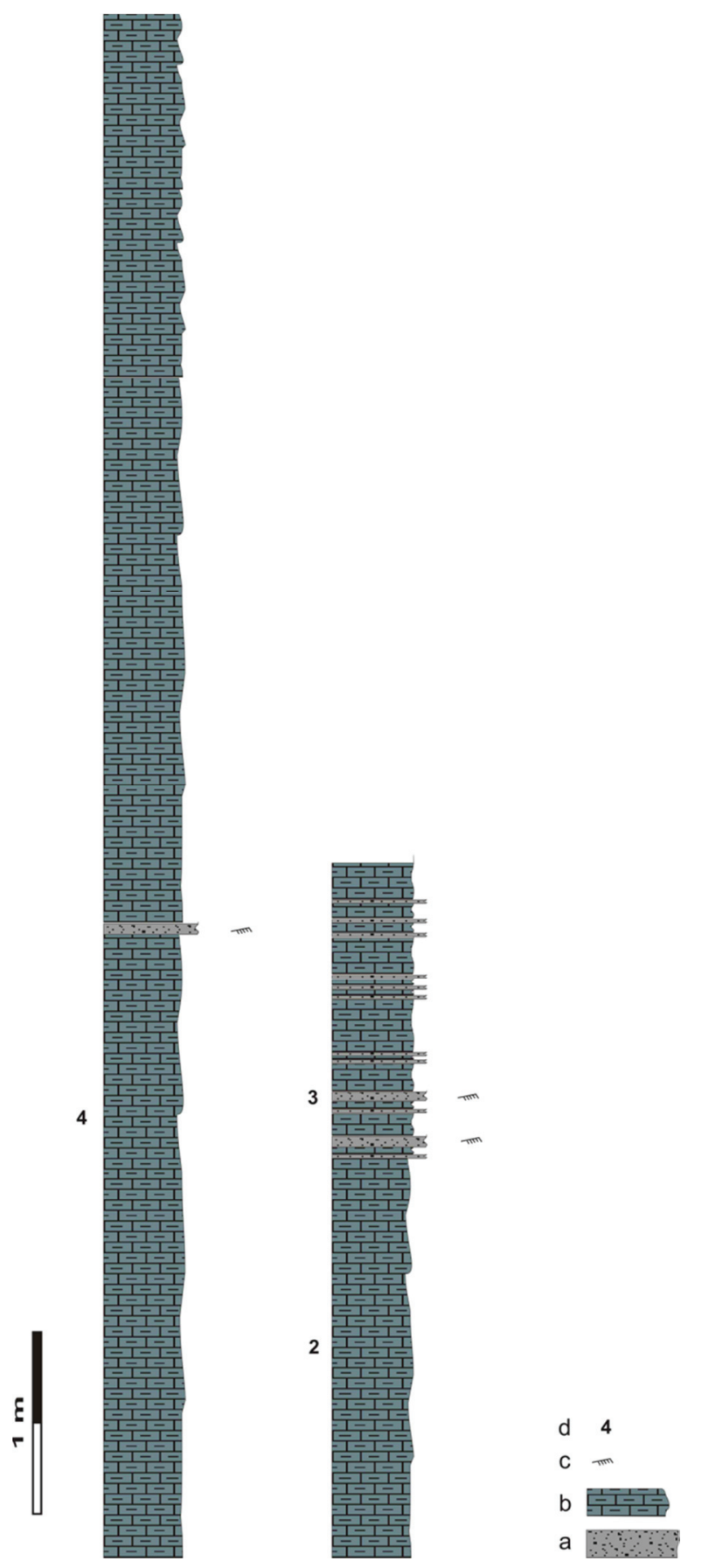

Fig. 8. Lithology of the Frydek Marls exposed along the Pluskawka Stream (Kamionna near Żegocina).

Explanations: $\mathrm{a}$-sandstones; $\mathrm{b}$ - marls; $\mathrm{c}$ - cross lamination; $\mathrm{d}$ - samples. 


\section{Lithologic classification of marls}

Marls that are bluish-gray in colour, soft, arenaceous, contain micas, structureless, slabby parting, that occur in beds that alternate in thickness from $1 \mathrm{~cm}$ to over $900 \mathrm{~cm}$ were distinguished. Sandstones, separating marly beds, show sharp bottoms and tops. They are bluish-gray, fine-grained, cross-laminated, calcareous, well-lithified and very thin-bedded $(1-6 \mathrm{~cm})$. In addition, the marls contain thin stringers of fine sand-sized grains, several millimeters thick.

\section{Detailed outcrop descriptions}

Three outcrops of the Frydek-type Marls near the aforementioned bridge were present (Table 8). The first of them, located at the bridge, exhibits a package of marls 1.5 meters thick. At the upstream end of the meander bend, in the left stream bank, there is a sequence 1.45 meters thick, composed of couplets of thin marl (from 1-28 cm, on average $9.8 \mathrm{~cm}$ thick) and very thin sandstone beds (from 1-6 cm, on average $1.9 \mathrm{~cm}$ thick) (Table 8). The third section was located at a distance of about $30 \mathrm{~m}$. In the escarpment several meters high, two very thick packages of marls (ranging in thickness from about 500 to $900 \mathrm{~cm}$ ) interbedded with one, very thin sandstone bed ( $5 \mathrm{~cm}$ thick) were exposed (Table 8 ; Fig. 8).

The grain-size distribution of the Frydek marls is limited within the silty and clayey fraction. Quantitative examination of a representative sample $\mathrm{Fr} / \mathrm{P} / 4$ has shown that the amount of sand-sized grains does not exceed 3\%, whereas that of silty one (carbonate grains excluded) is $22 \%$.

\section{Summary}

According to the present investigations, in these outcrops there are bluish gray coloured rocks. There are dominating marly beds of variable thickness, from very thin to very thick, occasionally containing streaks of sand-sized grains and underlain by very thin, crosslaminated sandstones. The sand/mud thickness ratio in sandstone-marl couplets varies within very broad limits from 1:1 to $1: 180$. The frequency percentage of sandstones in the sections measured is also variable (Table 8). Composite beds with a very thin sandy division and a thin marly one (sand/mud thickness ratio from 1:2 to 1:4) are arranged into packages interbedded with composite beds showing a thin sandy division and a thick or very thick marly one (Fig. 8; Table 8).

\section{Żegocina Marls}

Geological background and previous studies

The Żegocina Marls occur in the Sub-Silesian Unit (Table 1; Figs. 1, 2). They were called white siliceous marls and were reported to occur in the Lanckorona - Żegocina Tectonic Zone (Skoczylas-Ciszewska 1960). It is considered that the Żegocina Marls locally replace the dominating Upper Cretaceous variegated marls (Węglówka Marls) and those of gray, exotic-bearing marls (Frydek- type Marls). In the formal stratigraphic subdivision (Table 2) the Żegocina Marls (Senonian according to Skoczylas-Ciszewska 1960; Turonian-Early Senonian in the opinion of Ślączka and Kamiński 1998c; the Early Campanian according to Jugowiec-Narkiewicz, Jankowski 2001 and JugowiecNazarkiewicz 2007) were distinguished as a formation (Ślączka, Kamiński 1998c). 
The thickness of the Żegocina Marls in the Lanckorona-Żegocina Tectonic Zone is, according to Skoczylas-Ciszewska (1960), up to $30 \mathrm{~m}$. They were described as white to gray-greenish, very hard marls with lenses of brown cherts, occurring in thin beds and intercalated with dark, calcareous shales. They contain agglutinated and calcareous benthic and planctonic foraminifers, which indicate their Campanian-Maastrichtian age according to Skoczylas-Ciszewska (1960). Poorly preserved mixed Tethian-Boreal calcareous nannoplankton is similar to that occurring in other Upper Cretaceous marls of the Subsilesian Unit (Jugowiec-Nazarkiewicz, Jankowski 2001).

In the top, the Żegocina Marls pass gradually into the thick complex of the Rybie Sandstones. Their thickness is, in Skoczylas-Ciszewska's (1960) opinion, up to 650 meters and according to Słomka et al. (2006) is about 300 meters.

\section{$\underline{\text { Results of fieldwork }}$}

The Żegocina Marls were profiled and sampled in 2000 in the Lanckorona-Żegocina Tectonic Zone; in the valley of the Żegocina Stream, in the Żegocina Town and in the Pluskawka Stream in the Kamionna Village. In Żegocina these marls are exposed on both stream banks below the church and at the stage of fall. In Kamionna one outcrop was chosen for investigations, which was situated in the Pluskawka Stream above the earlier described Frydek Marls. These outcrops were observed about 50 years ago by SkoczylasCiszewska (1960) but their state is not considerably different. 16 representative samples of rocks were collected, including 10 of marls (Tables 3, 9; Fig. 9).

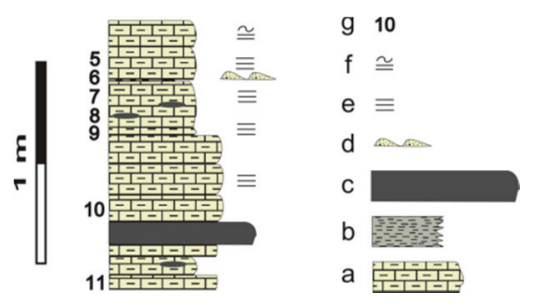

Fig. 9. Lithology of the Żegocina Marls (block 1) exposed along the Żegocina Stream. Explanations: $\mathrm{a}$ - marls; $\mathrm{b}$ - shales; $\mathrm{c}$ - cherts; $\mathrm{d}$ - starved ripples; e - parallel lamination; $\mathrm{f}$ - parallel and wavy lamination; $\mathrm{g}$ - samples. 


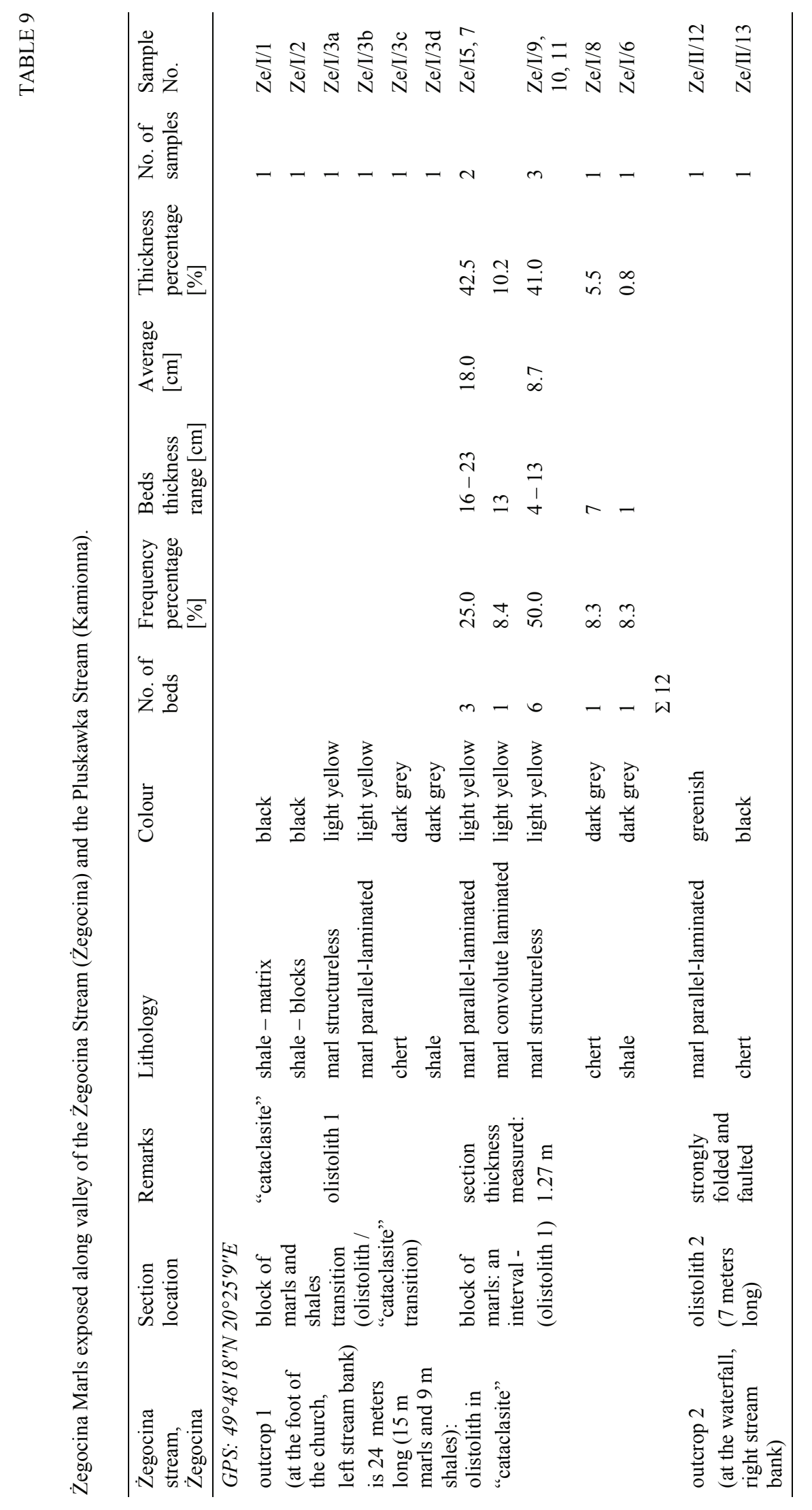




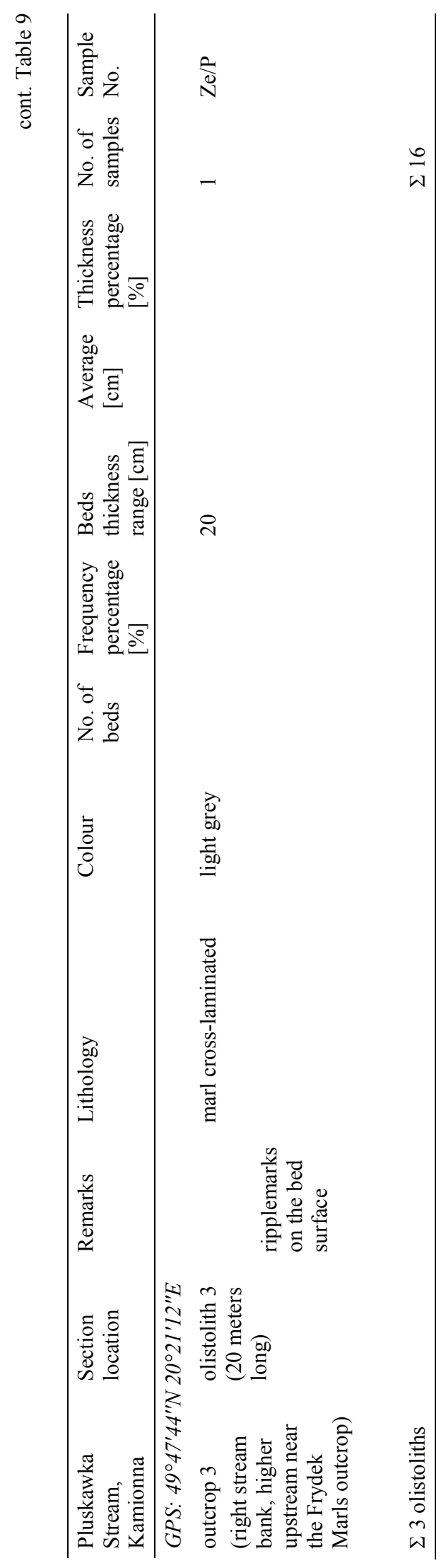




\section{Lithologic classification of marls}

Several types of marls were distinguished that differ in colour, structure, lamination and occurrence of burrows. There are hard, nonarenaceous marls with stringers of nearly black cherts, white-cream, light gray and greenish in colour, thin- to medium-bedded, struktureless, parallel-, wavy-, convolute-laminated, flaser-bedded and bioturbated. The bottom and top boundaries of their beds are sharp. Scours and silt laminae at the base were present. Some beds are separated by dark gray, calcareous shales.

\section{Detailed outcrop descriptions}

In the outcrop below the church in Żegocina there is a block of marls about $40 \mathrm{~m}^{3}$ in size (15 meters in length and 3 meters in height), contacting with black shales. In Jankowski's opinion (Jugowiec-Nazarkiewicz, Jankowski 2001), this is an olistolith within cataclasite. The latter can be described as black matrix with relics of slabby parting, black, silty shales. The olistolith consists of creamy, thin- to medium-bedded, very hard, split, structureless and parallel- occasionally convolute-laminated marls. They are faintly laminated, often discontinuously. The thickness of the lamines, marked by change of colour intensity and subtle variation of grain size, amounts to ca. $1 \mathrm{~mm}$ and is only rarely up to several millimeters. The thickness of lenses and streaks of dark gray chert in some beds is up to several centimeters. The bottom and the top of beds are sharp. Local scours and thin silt laminae a few millimeters thick at the base are common. Fine, dark-coloured burrows can be observed in some top parts of beds. Intercalations of dark gray, calcareous shales appear locally between marly beds. They are cut by numerous fine cracks (up to several millimeters thick), filled with calcite. 6 representative samples of rocks from the contact cataclasite-olistolith and 7 samples from olistolith were collected for detailed investigations (Table 9; Fig. 9). According to detailed studies, the thickness of beds of these marls in the outcrop in question varies from $4-23 \mathrm{~cm}$, whereby those of structureless variety are thinner than the beds of laminated marls. The frequency $(8.3 \%)$ and thickness $(0.8 \%)$ percentage of shales is negligible (Table 9).

The second olistolith is exposed near the stage of fall, about $100 \mathrm{~m}$ from the church on both sides of the stream. The outcrop in the right streambank is $7 \mathrm{~m}$ in length and about $1.5 \mathrm{~m}$ in height whilst in the left streambank the outcrop is $2 \mathrm{~m}$ long and $1.5 \mathrm{~m}$ high. The beds of marls are strongly tectonically deformed, often crushed. They are greenish, very hard, split and faintly laminated. The thickness of lamines and streaks does not exceed several millimeters. The laminae are poorly defined and slightly marked by change of colour intensity. In some beds lenticular cherts, up to several centimeters thick, can be seen. Numerous fissures are filled with calcite. Two samples of marl and cherts were collected from this olistolith (Table 9).

The third block is exposed in the right bank of the Pluskawka Stream in Kamionna, together with the previously described Frydek Marls. The exposure of the Żegocina Marls is about $20 \mathrm{~m}$ long and forms a steep escarpment more than $3 \mathrm{~m}$ high. We observed strongly folded thin to medium beds of laminated white-grayish marls. They are showing irregular parallel, wavy and lenticular lamination well defined by silt- and fine sand-sized grains and marked by variable tint of gray colour. Wispy streaks and lenses, several millimeters thick, are only sporadically composed of grains corresponding to fine sandy 
fraction. Small ripplemarks are visible at the surface of some beds. Representative samples of marl from this outcrop was collected for detailed studies (Table 9).

\section{Summary}

According to these studies, the Żegocina Marls that occur in these three blocks (olistoliths) differ in colour (cream, greenish, pale gray) and expressivity of the bed's internal structures. The latter are best visible in light gray variety of marls due to more distinct diversification of colour in lamines, streaks and lenses and of grains size as well. In general, however, all of the examined Żegocina Marls are characterized by delicate, irregular, wispy, faint lamination. Fine burrows, several millimeters in size, are visible in some beds, simlar to the thin streaks, several millimeters thick, composed of silt- and sand-sized grains. Such streaks locally develop into thin layers with scours in their bottom part. Within the beds of marls there are lenses, streaks and stripes of cherts of different thickness. In these marls they are up to $7 \mathrm{~cm}$ in size and substitute significant fragments of their beds (Fig. 9). On average the thickness of beds of Żegocina Marls studied amounts to about $18 \mathrm{~cm}$ (Table 9; Fig. 9). Their bottom and top boundaries are sharp and there are sporadic interlayers of shales.

\section{Jasienica Marls}

\section{Geological background and previous works}

The Jasienica Marls (Table 1; Figs. 1,2) were reported to occur in the Sub-Silesian Unit, that crop out in the Jasienica Tectonic Window, near Myślenice (Bieda et al. 1963; Paul et al. 1996). The Jasienica-type Marls, i.e. hard, greenish and yellowish, occasionally spotty, Cenomanian-Senonian in age, occurring in the Sub-Silesian and probably, also the Skole Unit (Paul et al. 1996) are exposed between Lanckorona and Myślenice in tectonic windows of the Lanckorona-Żegocina Tectonic Zone (Książkiewicz 1972). Marls that occur near Lanckorona are lithologically similar to those of Jasienica but are considered to be slightly younger (Turonian-Senonian), and are distinguished as the Jastrzębia Marls (Bieda et al. 1963). In some authors' opinion, the Jasienica Marls are locally substitute the Variegated Węglówka Marls and exotic-bearing Frydek Marls. In the formal stratigraphic subdivision they can be distinguished as a formation, similar to the Żegocina Marls (Table 2).

The thickness of the Jasienica Marls in the stratotype area near Myślenice (Jasienica, Rybie Nowe) does not exceed a dozen meters. They are described as hard, platy, dark in the bottom part and more light coloured upwards, spotty, intercalated with black shales (Paul et al. 1996).

In the cross-section of the Sub-Silesian series, the Jasienica Marls are placed (according to Bieda et al. 1963 and Paul et al. 1996) above the Barremian-Cenomanian Gaize Beds and under the Variegated Shales grading into the Węglówka Marls (Upper Cretaceous). The thickness of the Gaize Beds in this unit amounts to several tens of meters.

\section{$\underline{\text { Results of fieldwork }}$}

The Jasienica Marls were profiled and sampled in 2000 in the stratotype area i.e. in the Jasienica Tectonic Window. The outcrops are localized in the valley of Jasieniczanka Stream, flowing along the road through the Jasienica Village near the Myślenice Town. These exposures are situated at a distance of about $2 \mathrm{~km}$ from the sign at the entrance to the 
Jasienica Village, following the road in the direction of Myślenice towards Jasienica. 15 samples (including 12 of marls) were collected for detailed investigation from two outcrops at the right bank of the stream (Tables 3, 10; Fig. 10).

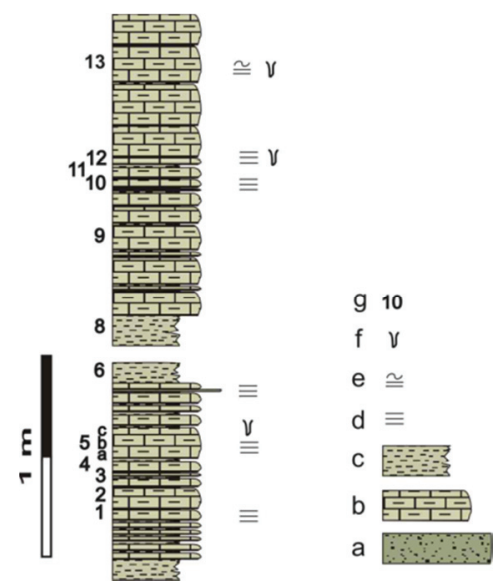

Fig. 10. Lithology of the Jasienica Marls exposed along Jasieniczanka Stream (Jasienica near Myślenice).

Explanations: $\mathrm{a}$ - sandstones; $\mathrm{b}$ - marls; $\mathrm{c}$ - shales; $\mathrm{d}$ - parallel lamination; $\mathrm{e}$ - parallel and wavy lamination; $\mathrm{f}$ - burrows; $\mathrm{g}$ - samples.

\section{Lithologic classification of marls}

Two differently coloured marls were distinguished: beige and mottled (beige-dark gray), hard, nonarenaceous, very thin- and thin-bedded, parallel laminated, bioturbated. Beds of marls can be separated by beige, calcareous shales and, sporadically, can be underlain by thin sandstone bed.

\section{Detailed outcrop descriptions}

In the first outcrop, $1 \mathrm{~m}$ high and about $3 \mathrm{~m}$ long, the beds are in normal position, are slightly tectonically deformed and dip fairly steeply to the SW. 62 beds of a total thickness of about 3 meters were profiled. These marls are very thin to thin-bedded $(1-20 \mathrm{~cm})$, intercalated with thin packets of shales (Table 10; Fig. 10). The average thickness of marl and shale beds is $7 \mathrm{~cm}$ and $1.8 \mathrm{~cm}$ respectively (Table 10). Some beds of marls have a sandstone layer in the bottom that is less than a few millimeters thick. The marls are pale beige in colour with yellowish spots when freshly broken and white coloured on weathered surfaces, hard, split, parallel-, occasionally wavy-laminated. Faint, irregular, often wispy, thin lamination (up to $1 \mathrm{~mm}$ ) is defined by variable brightness and tint of yellow colour. Fine burrows, gray in colour and several millimeters long, appear in the upper parts of the beds. Very thin fissures, filled with calcite, are very common. The shales are beige in colour, calcareous, fine fissile. The sandstones are grayish-beige, very fine-grained, fairly well-lithified, calcareous with hieroglyphs on their bottom surfaces. 


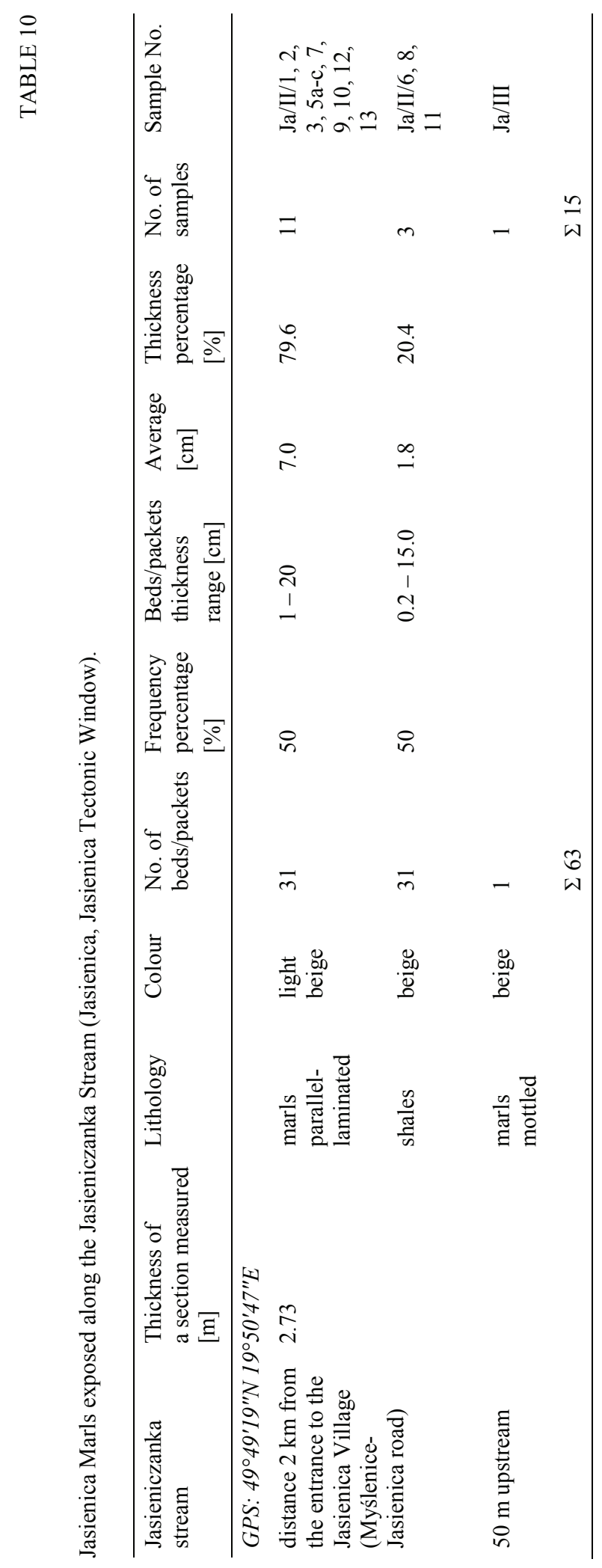


The second outcrop is localized 50 meters up the stream valley. It is a escarpment, about $3 \mathrm{~m}$ high. There are exposed steeply dipping, slightly tectonically deformed thin beds of hard, fairly split, strongly mottled beige-dark gray marls. These spots, about $1 \mathrm{~cm}$ in size, ameboidal in shape and dark gray coloured, are related to burrows. Faint parallel lamination is poorly preserved.

Summary

According to the present investigations, the Jasienica Marls are represented in the profiled outcrops by hard, beige coloured, faintly irregular parallel- and wavy-laminated variety of these rocks. The lamination is often obliterated by burrows, which are dark-gray in colour. The beds of marls are capped by thin calcareous shales and occasionally initiated by very thin sandstone layers.

\subsubsection{Eocene-Oligocene marls}

\section{Lącko Marls}

\section{Geological background}

The Łącko Marls (Table 1; Figs. 1, 2) form lenticular bodies, often several meters thick, within the Palaeogene sandy-shaly flysch of the Magura Unit, more precisely in the lower complex of the Magura Sandstones sensu Książkiewicz (1958). They appear in a narrow belt, about $10 \mathrm{~km}$ wide.

The Łącko Marls (Lower-Middle Eocene) were first distinguished by Uhlig (1888) as the Łącko Shales, and were called marls by Nowak (1924). The name Łącko Marls was introduced by Świdziński (1953). Książkiewicz (1958, 1966a) joined them with the lower complex of the Magura Sandstones, and called them first the Lacko Marls and, subsequently, the Łącko Beds. Węcławik (1969) has subdivided these beds, the lower corresponding to the lithotype of the Beloweza Beds, and the upper resembling the Magura Beds. Oszczypko (1992) has formalized the stratigraphic subdivision for facies zones of the Magura Unit. According to his scheme, the Lower Łącko Beds, which occur in the area east of Dunajec River are called the Żeleźnikowa Formation and, which appear in the area west of Dunajec River are called the Bystrica Formation. It should be remembered that Wójcik et al. (1996) tried to introduce one formal subdivision for the whole Magura Unit. Lower Łącko beds were subdivided into two members: the Łącko Marls and the Izby Shales and included into the Beloweza Beds, defined by formal name the Zarzecze Formation. However, actually the names proposed by Oszczypko (1992) are generally used. The Upper Łącko Beds, called until now the Maszkowice Beds, are in both formal subdivisions assigned to the Magura Formation and are distinguished as the Maszkowice Member (Oszczypko 1992; Wójcik et al. 1996) (Table 2).

The Lower Łącko Beds, recently called the Żeleźnikowa Formation vel the Bystrica Formation, show diachronous boundaries (Middle-Upper Eocene?). These are thin- and medium-bedded turbidites of Beloweza lithofacies intercalated with the Łącko Marls. The thickness of this complex is about 400 meters (Oszczypko 1991). It is underlain by the Beloweza Formation and overlain by the Magura Formation, more precisely by its 
Maszkowice Member, containing earlier distinguished the Upper Łącko Beds (Węcławik 1969).

The Upper Łącko Beds are actually called the Maszkowice Member (Middle Eocene). Their thickness is variable, from $25 \mathrm{~m}$ close to northern boundary of the northern Sacz Subunit (Książkiewicz 1966a) to above $1600 \mathrm{~m}$ in the area between the Dunajec and Raba Rivers (Bromowicz 1992a). They are characterized as medium- to thick-bedded sandstones of Magura lithofacies with Łącko Marls (Table 2). The observed occurrence of andesite clasts in these sandstones should be noted (Bromowicz, Oszczypko 1992). Marls disappear toward the top of this member (Książkiewicz 1958; Węcławik 1969; Bromowicz 1992a). The disappearance of the marls is accompanied in some cross-sections by the appearance of variegated shales at least $100 \mathrm{~m}$ thick, called until now the Jazowsko Member, which are actually defined by new formal name the Mniszek Variegated Shales Member (OszczypkoClowes 2001). Locally, the Mniszek Variegated Shales are overlain by Magura-type sandstone without marl bodies, distinguished by Węcławik (1969), called until now the Magura Beds (Sikora 1970) and defined by formal name the Poprad Sandstone Member, reaching up to $1800 \mathrm{~m}$ thick (Bromowicz 1992a). Above the Magura Formation in the Sacz Zone, in a few isolated localities, the Malcov Formation has been found (OszczypkoCloves 2001).

\section{Previous works}

The Lącko Marls, according to the published data, are hard, dark gray, showing platy parting and platy parting broken into blocks. They occur in beds from several centimeters to many meters thick. Some beds contain streaks of yellowish to brown cherts (Bieda et al. 1963). In the eastern part of the Nowy Sącz Subunit, Węcławik (1969) has distinguished two varieties of Łącko Marls, differing in colour: light bluish-gray and dark gray. Upon weathering the marls disintegrate to flaky, sharp-edged fragments. Weathered surfaces are rusty, light brown and yellow-cream in colour. In Węcławik's (1969) opinion, a characteristic feature of the Łącko Marls is the conchoidal fracture and lenticular shape of their beds, from several centimeters to 1 meter thick. He has also observed the occurrence of chert stringers in marls. Bromowicz (1992a) has distinguished two lithologic varieties of marls - arenaceous and nonarenaceous. The later comprise both light and dark varieties distinguished by Węcławik (1969).

The Łącko Marls and accompanying sandstones, as well as shales and deposits of submarine slumps, which occur in the Niski and the Sądecki Beskid Mts., were described in detail in the area between Izby Village and Łącko Town by Bromowicz and Górniak (1988). In this area, the Lower Łacko Beds (Żeleźnikowa Formation) consist predominantly of shales (52.5\%) and sandstones (39.2\%). The content of marls is negligible (8.3\%) (a few beds of nonarenaceous marls up to $2 \mathrm{~m}$ thick). On the other side, in the Upper Łącko Beds, the thickness percentage of marls, sandstones and shales is similar and amounts to $30 \%$ each. The remaining $10 \%$ is represented by submarine slumps. In general, marls occur in sequences, initiated by deposits of submarine slumps, followed subsequently by arenaceous marls, nonarenaceous marls and shales (Bromowicz 1992a; Bromowicz, Górniak 1988). 


\section{Results of fieldwork}

The present author has selected samples of marls for these studies from the typical outcrop of the Maszkowice Member (Table 2) in the Sądecki Beskid and in the south part of the Wyspowy Beskid Mts. (environs of Łącko Town). This outcrop, which was profiled, sampled and described by Bromowicz (1992b), is situated in the valley of the Kamienica River, about $100 \mathrm{~m}$ above the outflow of the Czaczowiec Stream and close to the bridge of Maciejowa-Czaczów road (Table 11; Fig. 11). It is localized in the northern, marginal part of the Nowy Sącz (Bistrzyca) Subunit, within the Nawojowa-Rybien Anticline. In this outcrop nearly $100 \mathrm{~m}$ of the member in question is exposed, represented by marls, sandstones, shales and deposits of submarine slumps, steeply dipping to the SSW. 10 samples of rocks from these outcrop were collected -5 of marls, 2 of shales and 3 of sandstones (Tables 3, 11; Fig. 11).

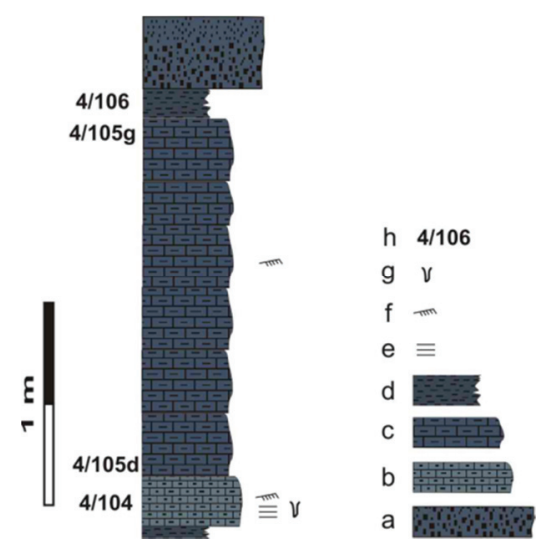

Fig. 11. Lithology of the Łącko Marls exposed along the Kamienica River in Czaczów near Maciejowa (by Bromowicz, Górniak 1988, Figs. 3 and 8C).

Explanations: $\mathrm{a}$ - sandstones; $\mathrm{b}$ - arenaceous marls; $\mathrm{c}$ - nonarenaceous marls; $\mathrm{d}$ - shales; $\mathrm{e}$ - parallel lamination; $\mathrm{f}$ - cross lamination; $\mathrm{g}$ - burrows; $\mathrm{h}$ - samples. 


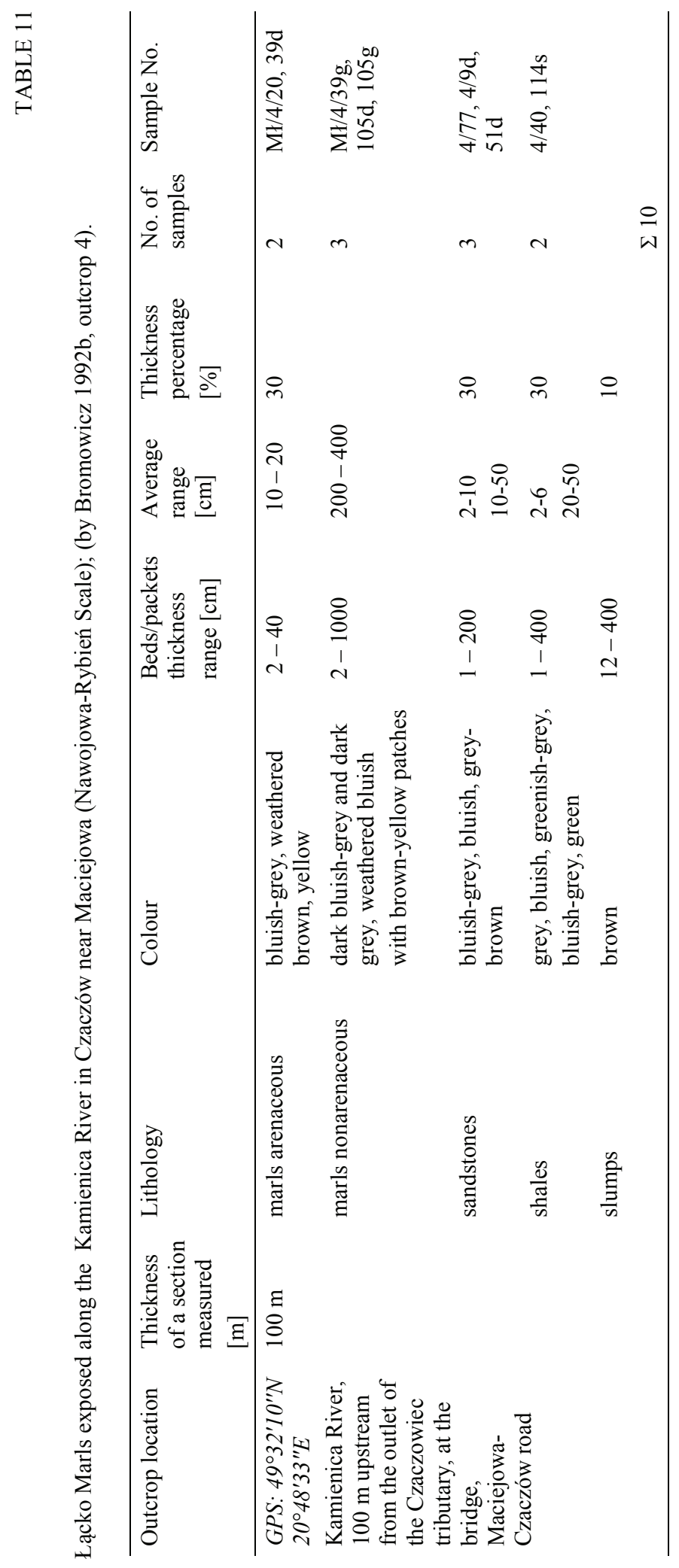




\section{Lithologic classification of marls}

Marls are represented by two lithological varieties: arenaceous and nonarenaceous. The former occur in beds less than $20 \mathrm{~cm}$ thick. These rocks are compact, bluish-gray, when weathered brown and yellow in colour, showing parallel and ripple-cross lamination, and parting along laminae. Parting planes are enriched in mica flakes. Nonarenaceous marls occur in beds up to 10 meters thick and form the thickest-bedded component of the sequence. They are deep bluish-gray, occasionally dark gray when fresh and blue with yellow, brown and violet coatings on weathered surfaces. Cross lamination is sometimes present. They are strongly cracked, show conchoidal fracture and disintegrate into flaky fragments. Burrows are fairly common in both arenaceous and nonarenaceous varieties of the Łącko Marls. Sandstones, shales and deposits of submarine slumps were described in detail by Bromowicz (1992a, b) as well as Bromowicz and Górniak (1988).

\section{Summary}

According to the lithological features of the Łacko Marls, they can be assigned to gray, bioturbated marls, represented by two varieties, differing in grain-size: arenaceous (bluishgray) and nonarenaceous (bluish-gray and dark gray). In the thin-bedded variety there are both arenaceous and nonarenaceous marls, whilst in the thick-bedded variety there are only nonarenaceous marls. The laminated variety appears in both varieties, differing in grainsize, whereas the structureless variety only appears in nonarenaceous marls. Platy fragmentation is visible in parallel laminated arenaceous marls, whilst slabby parting is visible in structureless, nonarenaceous ones. Arenaceous marls appear in the bottom of nonarenaceous marl beds (Bromowicz 1992a, b; Bromowicz, Górniak 1988).

\section{Zembrzyce Marls (marls from the Zembrzyce Beds)}

\section{Geological background and previous studies}

The Zembrzyce Marls (marls from the Zembrzyce Beds) (Table 1; Figs. 1, 2) occur in the outermost part of the Magura Unit. The Zembrzyce Marls and, described earlier, the Łącko Marls, are both members of the Magura Beds sensu Książkiewicz (1974), but the former belongs to the Magura Beds of muscovite facies, whilst the latter belongs to the glauconite one. The Zembrzyce Marls closely resemble the Łącko Marls, as was already emphasized by Bieda et al. (1963), but the Zembrzyce Beds appear later and in another part of the Magura Basin.

The Zembrzyce Marls are a component of the Sub-Magura Beds, which are also called the Zembrzyce Shales and, more recently, the Zembrzyce Beds. The Sub-Magura Beds were distinguished by Książkiewicz $(1935,1974)$ in the lowermost part of the Magura Beds in the Siary Subunit, west of the Dunajec River. He has proposed for this area a triple subdivision of Magura Beds into the Sub-Magura Beds (Zembrzyce Shales), the Magura Sandstones of glauconite facies and the Supra-Magura Beds (Budzów Shales). Recently, the Magura Beds are called the Magura Formation (Oszczypko, Oszczypko-Clowes 2006) and the Sub-Magura Beds vel Zembrzyce Shales - Zembrzyce Beds (Oszczypko 1992). The Zembrzyce Beds are considered to be a member of the Magura Formation (Wójcik et al. 1996) (Table 2). 
The Zembrzyce Beds (Eocene-Oligocene, mainly Upper Eocene) consists of marls of Łącko type, shales, glauconitic sandstones and deposits of submarine slumps. Typical Zembrzyce Beds are characterized as gray, greenish, olive, less commonly black and brown marls and slabby parting shales, accompanied subordinately by thin- to medium-bedded, calcareous, glauconitic sandstones, often showing convolute lamination (Bieda et al. 1963). Submarine slump deposits occur in the cross-sections with a considerable percentage of marls (Bromowicz 1992a). Bromowicz (1992a) has distinguished their arenaceous and nonarenaceous varieties within the Zembrzyce Marls. In the Zembrzyce Beds, outcropping in Pewla Mała, Zembrzyce and Budzów, intercalations of bentonized tuffites were found (Cieszkowski et al. 1985; Książkiewicz 1966b, c, 1974). The tuffites from Pewel Mała were dated and the result is $36.9 \pm 1.9 \mathrm{Ma}$ (Cieszkowski et al. 1985).

The thickness of the Zembrzyce Beds in the Siary Subunit in the area west of the Dunajec River is very diversified. In Bromowicz's (1992a) opinion it varies from 0-2000 $\mathrm{m}$. It is considered that the Zembrzyce Beds are best and typically developed in the area west of the Dunajec River.

The Zembrzyce Beds in the northern part of the area west of the Dunajec River are underlain by the Variegated Shales and the Pasierbiec Sandstones, and in southern part by the Hieroglyphic Beds. In the formal subdivision these are the Variegated Łabowa Shales Formation, the Pasierbiec Sandstone Member and the Hieroglyphic Formation.

The Zembrzyce Beds in this area are overlain by two younger members of the Magura Formation: the Magura Sandstones of glauconitic facies and the Budzów Beds.

It is worth adding that in the Siary Subunit in the area east of the Dunajec River and in the neighbouring, northern part of the Rača Subunit, in the bottom of the Magura Beds there are some local deposits that often differ lithologically from typical Zembrzyce Beds. Nevertheless, based on their position and recent micropaleontologic studies and nannoplankton data, they are considered to represent the Zembrzyce Beds (OszczypkoClowes 2001; Leszczyński, Malata 2002).

In the Siary Subunit in the area east of the Dunajec River a twofold subdivision of the Magura Beds is applied. The lower part is represented by glauconitic sandstones called the Wątkowa Sandstones (Koszarski, Koszarski 1985a, b), which are overlain by the Małastów Shales (Bromowicz 1992a). The former are underlain locally by a thin complex $(20-30 \mathrm{~m})$ of mostly clayey rocks (Sikora 1970), called the Szymbark Shales (Kopciowski 1996), considered by some authors to represent the Zembrzyce Beds (Oszczypko-Clowes 2001). In Bromowicz's (1992a) opinion, they represent green noncalcareous shales-bearing transition deposits between the Variegated Shales and the Wątkowa Sandstones, which are distinctly different from typical Zembrzyce Beds. In Sikora's (1970) opinion, the lower part of this complex, which is composed mostly of green calcareous and noncalcareous shales, can be included in the Variegated Shales whilst the upper one is considered to be equivalent to the Globigerina Marls. It is worth adding that in the Folusz locality, the Szymbark Shales contain intercalations of dacite-andesite tuffites (Sikora 1970), $32.9 \pm 1.3 \mathrm{Ma}$ in age (Van Couvering et al. 1981). In some authors' opinions (Gedl, Leszczyński 2005), Lower Oligocene deposits resembling the Zembrzyce Beds (about $33 \mathrm{~m}$ thick) occur in Folusz above the Szymbark Shales (Uppermost Eocene-Lowermost Oligocene).

In the Rača Subunit, a considerable percentage of shales in the bottom of the Magura Beds appear at the northern boundary of this zone, close to the contact with the Siary 
Subunit. In the opinion of Oszczypko et al. (1990), they represent poorly developed Zembrzyce Beds. Their thickness does not exceed $110 \mathrm{~m}$ (Oszczypko-Clowes 2001). It is also considered that the Zembrzyce Beds occurring in the Rača Subunit are equivalent to the Żeleźnikowa Formation (Lower Łącko Beds), distinguished in the Bystrica Subunit (Oszczypko, Oszczypko-Clowes 2006). This opinion was already expressed by Książkiewicz (1966a), who considered Middle Eocene Zembrzyce Beds, occurring locally in the Babia Góra region, as equivalents to the Łącko Marls. It should be remembered that in the Rača subunit, also in upper part of the profile, lenticular bodies of shales and marls occur within sandstones of the Magura Formation (Poprad Sandstones Member). According to Bieda et al. (1963), these deposits are similar to the Sub-Magura Beds (Zembrzyce Beds), the Supra-Magura Beds (Budzów Beds) and the Łącko Beds. Książkiewicz (1958) has distinguished them as the Intra-Magura Shales.

\section{Results of fieldwork}

The Zembrzyce Beds were profiled and sampled in the region of their typical development i.e. in the Siary Subunit, west of the Dunajec River. The study in the field were carried out in 1999, in Zembrzyce and Budzów near Sucha Beskidzka. 25 representative samples were collected from 57 profiled beds in Zembrzyce and 19 in Budzów (Tables 3, 12a-c).

\section{Lithologic classification of marls}

Among the generally gray coloured, bioturbated Zembrzyce Marls, arenaceous and nonarenaceous varieties that differ in grain-size were distinguished. The differences are also visible in the thickness of the beds and lamination types (parallel-, cross laminated and structureless varieties). The thin- to medium-bedded ones are arenaceous and nonarenaceous marls, whilst thick- and very thick beds occur only in the nonarenaceous variety. Parallel-laminated arenaceous and nonarenaceous marls are common, whilst the former is cross-laminated and the latter is structureless. The Zembrzyce Marls are olive-, brownish- and bluish-gray in colour. The bluish-gray variety appears to be cross-laminated arenaceous marls. Platy fragmentation occurs among parallel-laminated arenaceous marls, whilst there is massive variety and slabby parting within the nonarenaceous ones. Arenaceous marls underlie the beds of nonarenaceous variety.

\section{Detailed outcrop descriptions}

Zembrzyce area

In Zembrzyce, the Zembrzyce Marls (Tables 12a-b; Fig. 12) are exposed in the Pilchówka Stream, right-bank tributary of the Paleczka River. According to Książkiewicz (1966b), this outcrop presents a good cross-section of a narrow anticline consisting of Palaeocene Variegated Shales, covered by the Zembrzyce Beds. Five fragments of the cross-section (Table 12a), exposed over a distance of more than 800 meters long, were described and sampled. The beds are in normal position and dipping at small angle to the S. The oldest deposits are exposed in upper part of the Pilchówka Stream and the youngest are exposed close to its outlet to the Paleczka River. A section of the Zembrzyce Beds that is 20 meters long was described and measured. Arenaceous and nonarenaceous marls, 
sandstones, deposits of submarine slumps and probable bentonite intercalation were distinguished (Tables 12a-b).

The nonarenaceous marls, olive and brown in colour, are massive, loaf-like and slabby parting, structureless, feebly hard, and after hammering disintegrates into flaky, conchoidal fragments. In some beds, locally, very thin $(1-2 \mathrm{~mm})$, delicate, parallel, slightly wavy and lenticular lamination is visible, marked by accumulations of silt-sized grains. Very fine mica flakes occur at the parting surfaces that can be particularly seen in the brown coloured variety. The thickness of beds varies from $1-250 \mathrm{~cm}$, whereby the most common are those about 1 meter thick (Tables 12a, b).

The arenaceous marls occur in two structural varieties: parallel- and cross-laminated. Parallel-laminated arenaceous marls are olive and brown, display platy fragmentation and are hard and brittle. They always appear under nonarenaceous marls of the same colour. Similar to the nonarenaceous variety, they also contain fine mica flakes. The thickness of beds of arenaceous parallel-laminated marls varies from $22-51 \mathrm{~cm}$. The beds of overlaying, nonarenaceous variety are several times thicker (Fig. 12). Cross-laminated marls are bluish-gray, occasionally brown and very hard, split. They consist of single set or co-set of delicate cross laminae marked by change in colour intensity. When weathered, they are pale brownish-gray in colour. Lamination, marked by brown colour, is more clearly visible on weathered surfaces. The thickness of beds of arenaceous cross-laminated marls varies from $2-25 \mathrm{~cm}$. Undersurfaces of beds are sometimes covered by hieroglyphs.

The sandstones are very fine-grained, fairly compact, brittle and spotty, olive-yellowishgray in colour, showing parallel lamination. They resemble the parallel-laminated variety of arenaceous marls. Their beds are $4-150 \mathrm{~cm}$ thick.

The 2 centimeter thick intercalation, distinguished due to its creamy-yellow colour, was called bentonite (Fig. 12). The rock is brittle and calcareous, underlain by a thin $(1 \mathrm{~cm})$ layer of yellow-brown sandstone, containing streaks of brown chert that are several millimeters thick.

Coarse- to very coarse-grained deposits of submarine slumps are olive-gray, friable, poorly sorted with a matrix-supported fabric and subangular fragments of marly beds. In the top they grade into marls. This fact confirms the relation of marls of Łacko type to submarine slumps, reported by Bromowicz (1992a; Bromowicz, Górniak 1988). 


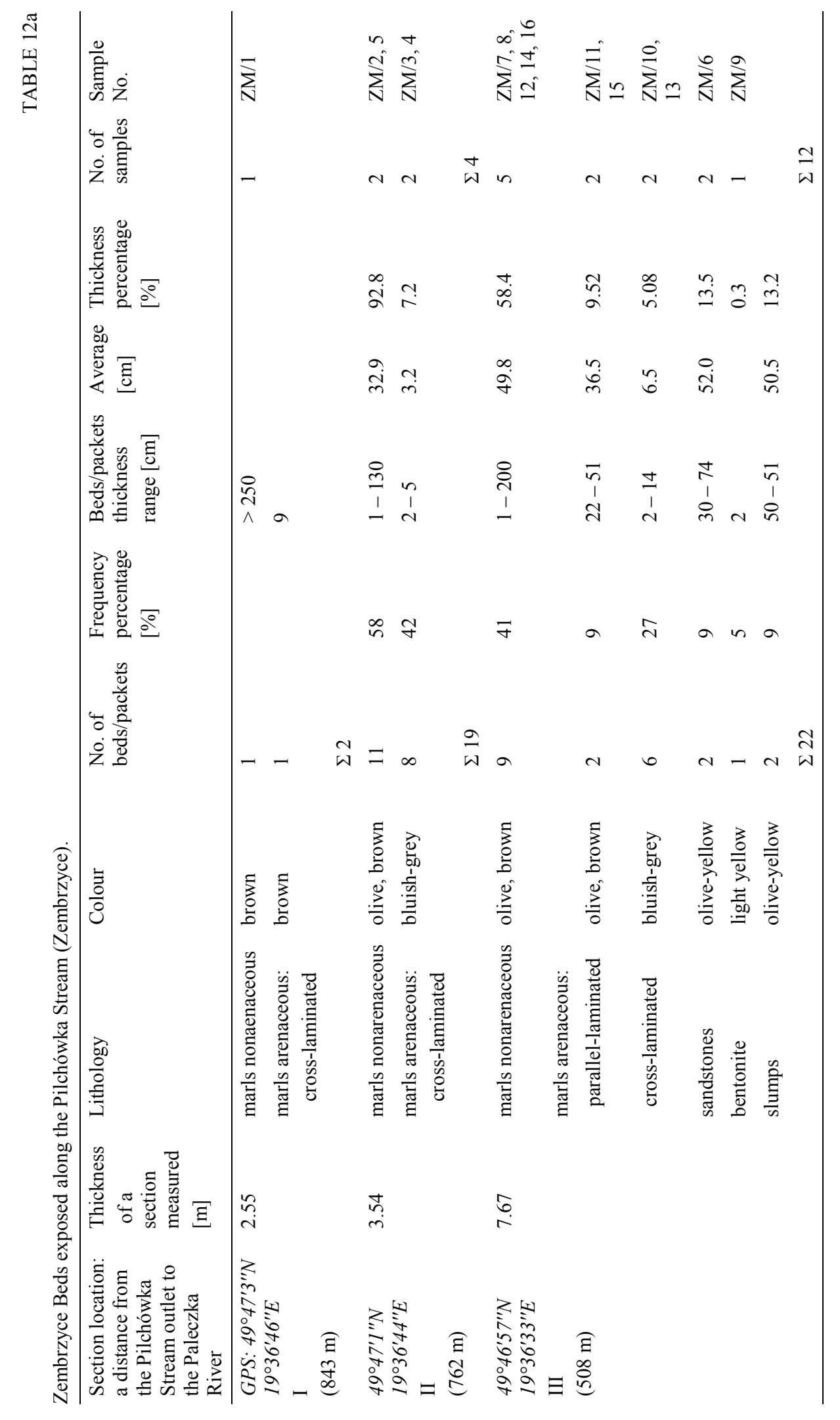




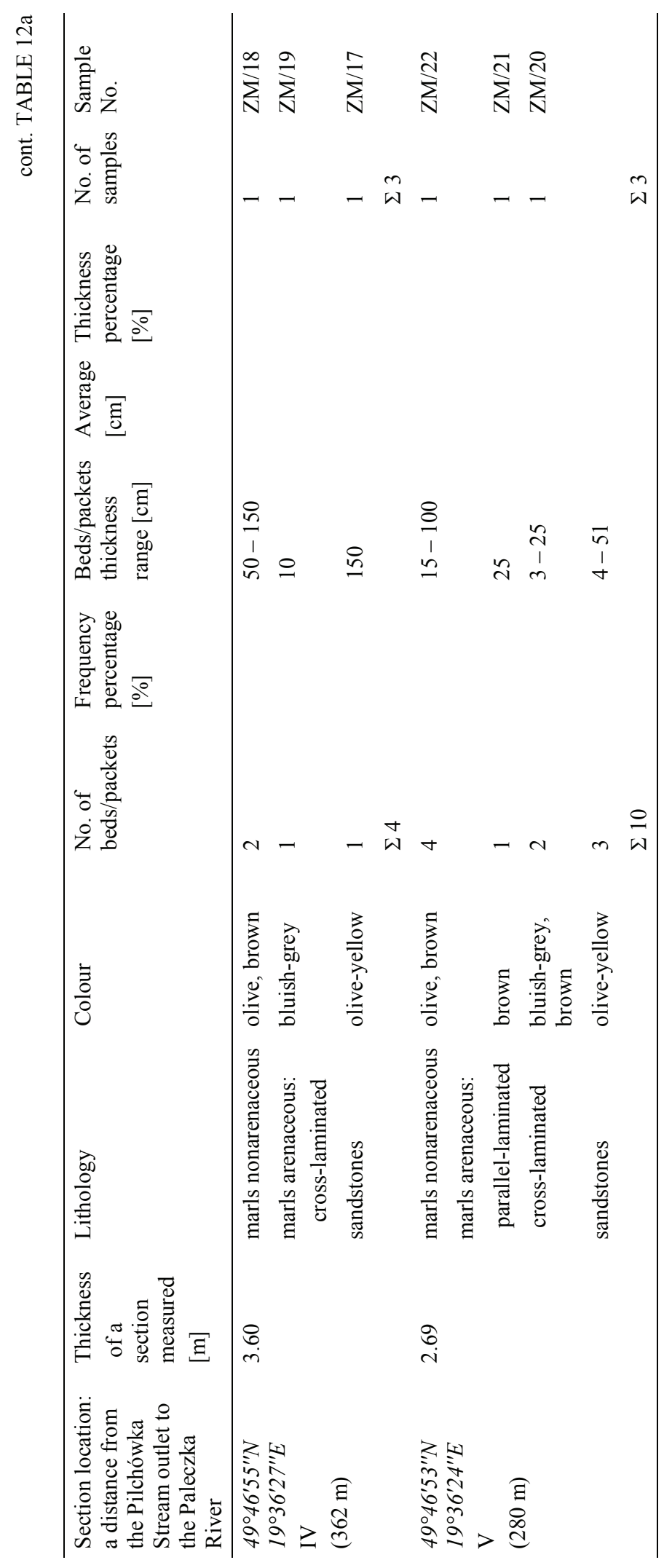




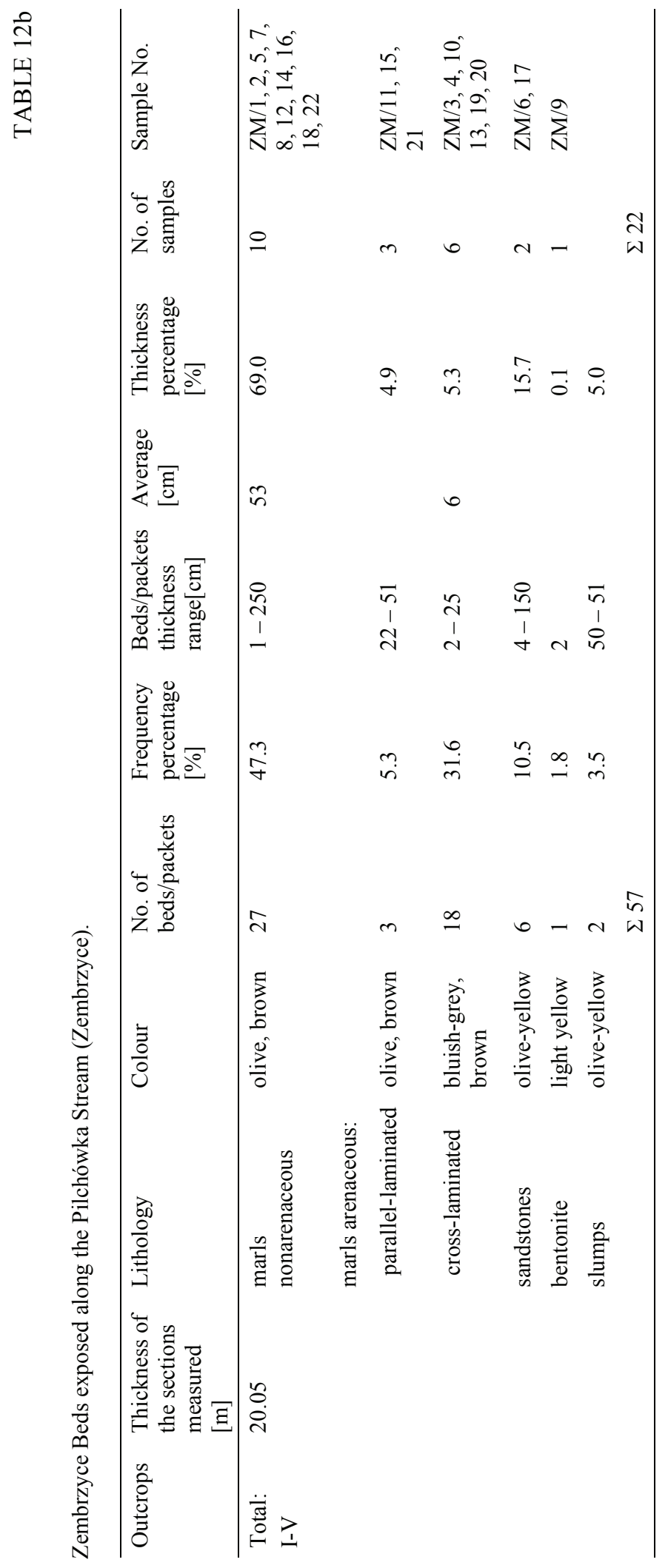




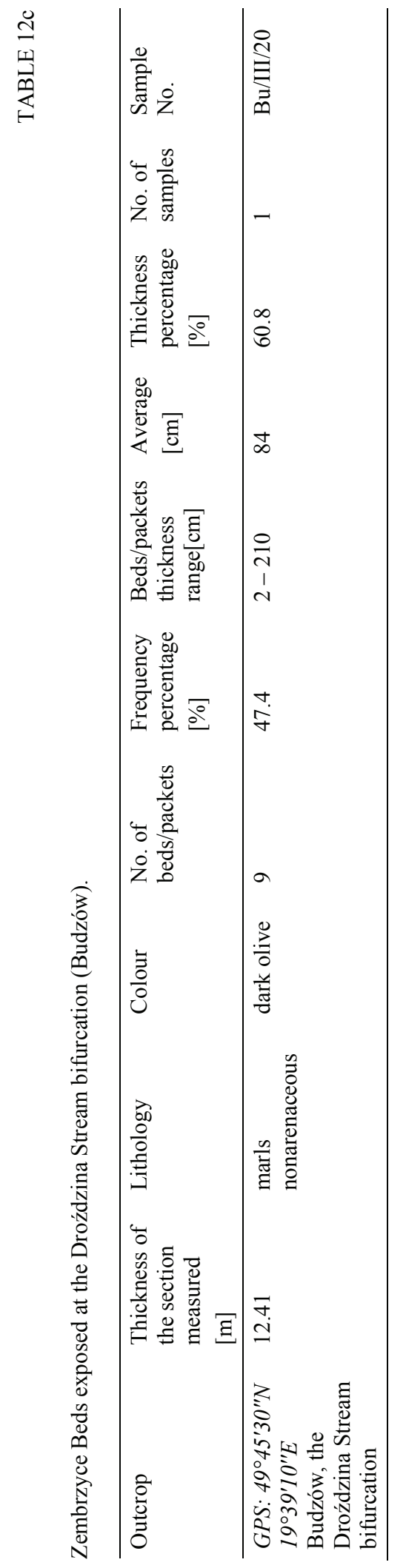



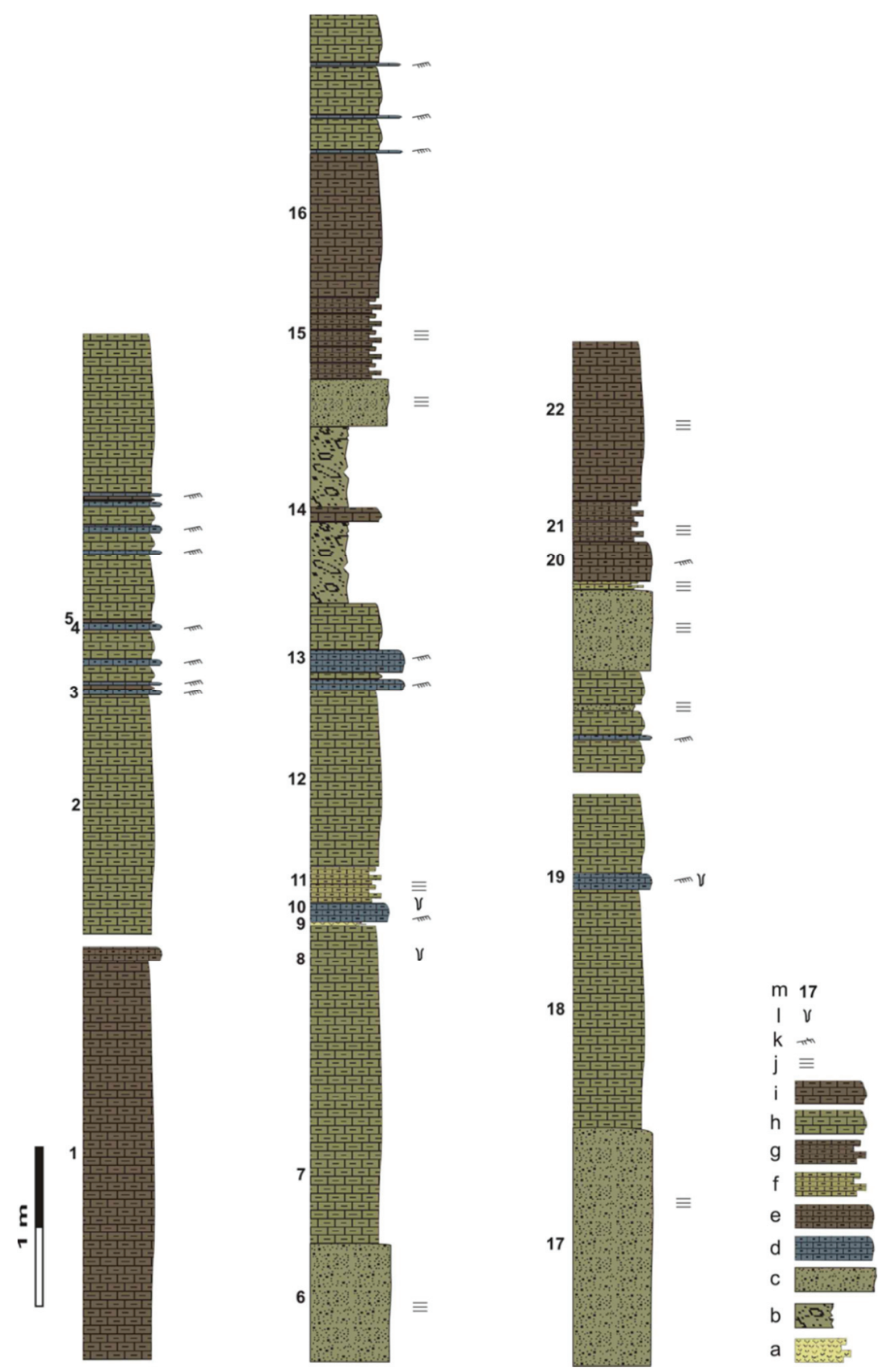

Fig. 12. Lithology of the Zembrzyce Beds exposed along the Pilchówka Stream (Zembrzyce). Explanations: $\mathrm{a}$ - bentonite; $\mathrm{b}$ - slumps; $\mathrm{c}$ - sandstones; d-e - arenaceous marls cross-laminated: $\mathrm{d}$ - bluish-grey; e - brown; f-g - arenaceous marls paralell-laminated: $\mathrm{f}$ - olive; $\mathrm{g}$ - brown, $\mathrm{h}-\mathrm{i}$ - nonarenaceous marls: $\mathrm{h}$ - olive; $\mathrm{i}$ - brown; $\mathrm{j}$ - parallel lamination; $\mathrm{k}$ - cross lamination; 1 - burrows; $\mathrm{m}$ - samples. 
According to the present studies, in the Pilchówka Stream in Zembrzyce, the thick beds of olive and brown nonarenacous marls (on average $53 \mathrm{~cm}$ thick) are exposed, intercalated by thin (about $6 \mathrm{~cm}$ thick) beds of bluish-gray, very hard, cross-laminated arenaceous marls. Much less common are medium bedded, very fine- to fine-grained, olive-yellowishgray, parallel laminated sandstones and brownish-gray deposits of submarine slumps, containing fragments of marly beds. Moreover, an intercalation of cream coloured bentonite occurs. Some beds of nonarenaceous marls are initiated by parallel laminated, brittle variety of arenaceous marls (Tables 12a, b; Fig. 12). Among five fragments of this profile, characterized in Table 12, the third one resembles that described in 1966 by Książkiewicz (1966b). The top parts of both profiles differ in the number of bentonite intercalations. In the profile described in this paper, similar to the Zembrzyce Beds exposed in Budzów (Książkiewicz 1974), only one bentonite intercalation is visible.

\section{Budzów area}

In Budzów the profiled and sampled Zembrzyce Beds are exposed in the Droździna Stream valley (Table 12c). This profile was described by Książkiewicz (1966b) and Oszczypko-Clowes (2001). The outcrop is localized in the upper limb of the overturned Budzów Syncline. The beds are overturned and dipping to the S. The Zembrzyce Beds are exposed close to the bifurcation of stream, about $1420 \mathrm{~m}$ from the bridge in the SułkowiceSucha Beskidzka road. Their thickness is about $100 \mathrm{~m}$. They are underlain by the Variegated Shales and the Pasierbiec Sandstones, and are overlain by the Magura Glauconite Sandstones with the Budzów Beds in the top. About 12 meters of the Zembrzyce Beds were profiled in this outcrop. They are represented by nonarenaceous and arenaceous marls and sandstones (Table 12c). They are similar to the above described rocks exposed in Zembrzyce in southern limb of the anticline, adjacent in the north to the Budzów Syncline. They differ only in the darker colour and the common occurrence of fissures filled with calcite, particularly in the sandstones. Moreover, the latter also show parallel lamination and graded bedding as well (Table 12c).

\section{Summary}

According to the present investigations, the Zembrzyce Marls in the Zembrzyce and Budzów outcrops are represented predominantly by nonarenaceous variety $(47.3 \%$ in Zembrzyce, $47.4 \%$ in Budzów) and due to the high thickness of their beds, their thickness percentage is up to $70 \%(69.0 \%$ and $60.8 \%$ respectively). The frequency percentage of cross laminated arenaceous marls in these outcrops amounts to $31.7 \%$ and $15.8 \%$ in Zembrzyce and Budzów respectively, but due to the low thickness of their beds (less than $30 \mathrm{~cm})$ their percentage content is low $(5.3 \%$ and $4.1 \%)$. In the Zembrzyce outcrops, the frequency percentage the of arenaceous, parallel laminated variety is lower $(5.3 \%)$ than cross-laminated one $(31.7 \%)$, but due to the higher bed's thickness of the former, their thickness percentage is similar (4.9\% and 5.3\% respectively). The thickness percentage of a few sandstone beds, due high bed's thickness is $15.7 \%$ in Zembrzyce and $23.6 \%$ in Budzów. The frequency and thickness percentage of submarine slumps is low (Tables $12 \mathrm{~b}, \mathrm{c})$.

The present studies of the profiled fragment of Zembrzyce Beds have shown that nonarenaceous marls appear directly above the submarine slumps, overlie cross-laminated 
arenaceous marls or are the closing member of sequences initiated by products of submarine slumps overlaid by sandstones and arenaceous marls (Fig. 12). Nonarenaceous marls underlain by the cross-laminated arenaceous one are sometimes initiated by parallellaminated arenaceous variety. The sandy division of these composite beds (arenaceous marls) that show cross lamination is massive, while the parallel-laminated ones separate into platy fragments. The overlaying member that is depleted of sand (nonarenaceous marls) displays flaky fragmentation. The dominance of nonarenaceous marl division (sand/mud thickness ratio) in these beds is 1:3. In bipartite beds that are composed of crosslaminated sandy division and overlaying sandy depleted division only, the sand/mud thickness ratio is from 1:2 to 1:30 (Fig. 12).

\section{Budzów Marls (marls from the Budzów Beds)}

\section{Geological background and previous studies}

The Budzów Marls (marls from the Budzów Beds) (Table 1; Figs. 1, 2), as with the Zembrzyce Marls, occur only in the outer northern part of the Magura Unit, but whilst the last were beginning the sedimentation of the Magura Beds of the glauconite facies, the Budzów Marls are final member of this sedimentation products. Both types of marls appear in the Siary Zone.

The Budzów Marls, as a component of the Supra-Magura Beds, are also known as the Budzów Shales and, recently, the Budzów Beds. The Supra-Magura Beds, later called the Budzów Shales, were distinguished by Książkiewicz (1966a) in the uppermost part of the Magura Beds in the Siary Zone, west of the Dunajec River. As already mentioned, in this part of the Siary Zone triple subdivision of the Magura Beds is applied: the Sub-Magura Beds (Zembrzyce Shales or Beds), the Magura Sandstones of glauconite facies and the Supra-Magura Beds (Budzów Shales). Actually the Supra-Magura Beds vel Budzów Shales are defined as the Budzów Beds and are considered to represent a member of the Magura Formation (Oszczypko 1992; Wójcik et al. 1996) (Table 2).

The Budzów Beds (Upper Late Eocene - Early Oligocene, mainly Lower Oligocene), similarly to the Zembrzyce Beds, are the member of the Magura Formation showing a dominance of marly-shaly deposits over sandstones. In the opinions of Książkiewicz (1966a, 1974) and Bromowicz (1992a), they consist predominantly of gray-green and gray marls, light gray when weathered, and less numerous beds of medium-bedded glauconite sandstones. There are only sporadically packages of black shales and individual intercalations of brown and black cherts, several centimeters thick. Besides, in the Krzczonów locality these beds contain thin tuffitic intercalations, distinguished by the light gray colour and visible biotite flakes (Leszczyński, Malata, 2002). Moreover, arenaceous and nonarenaceous Budzów Marls were distinguished by Bromowicz (1992a).

The thickness of the Budzów Beds in the Siary Zone, west of the Dunajec River, varies from $75-750 \mathrm{~m}$ according to Bromowicz (1992a), and amounts to about $600 \mathrm{~m}$ according to Książkiewicz (1966a, 1974).

The Budzów Beds are underlain by the Magura Sandstone of glauconite facies. In the Siary Zone, west of Dunajec River, the Budzów Beds are the youngest deposits of the Magura Unit. 
It is worth adding that in the top of the Magura Beds in the Siary zone, east of the Dunajec River, above the Wątkowa Sandstone, there is a member that Bromowicz (1992a) called the Małastów Beds. In this author's opinion they are different lithologically from the Budzów Beds. Oszczypko-Clowes (2001) as well as Oszczypko and Oszczypko-Clowes (2006) consider them to represent the Budzów Beds, whilst in Leszczyński and Malata's (2002) opinion these names are synonymous. It should be emphasized that the Małastów Shales (Lower Oligocene) are locally overlain by an olistostrome distinguished as the Gładyszów Beds (Upper Oligocene).

\section{Results of fieldwork}

The Budzów Beds were profiled and sampled in 1999 in the Droździna Stream in Budzów. These are some of the best outcrops of the Budzów Beds (Książkiewicz 1966c; Oszczypko-Clowes 2001). In the valley of the Droździna stream a fragment of upper limb of the overturned Budzów Syncline is exposed, consisting of the Variegated Shales and the Pasierbiec Sandstones (Łabowa Variegated Shales Formation), overlain by the Magura Formation (Zembrzyce Beds, Magura Sandstones of the glauconite facies and Budzów Beds). The thickness of the Budzów Beds in this outcrop is about $300 \mathrm{~m}$. They occur in the uppermost part of this profile, and are underlain by a complex of the Magura Sandstones that is $325 \mathrm{~m}$ thick and, successively, the Zembrzyce Beds.

The total length of the two profiled cross-sections of the Budzów Beds exposed in the Droździna Stream valley (at the distance about $500 \mathrm{~m}$ upstream from the bridge of the Sułkowice-Zembrzyce road) is about $30 \mathrm{~m}$. It consists of 67 overturned beds, dipping to the S (176/30). The samples represent nonarenaceous (8) and arenaceous marls (11) and sandstones (3) (Tables 3,13). Moreover, in the Droździna Stream valley within the Budzów Beds the submarine slump deposits were visible (Fig. 13).

\section{Lithologic classification of marls}

The examined Budzów Marls are hard, bluish-gray, greenish-gray and brownish-gray in colour. Among two varieties that differ in grain-size, thin- and medium-bedded are both arenaceous and nonarenaceous marls, whilst thick and very thick packages form only the latest one. The parallel-laminated are both arenaceous and nonarenaceous marls, the crosslaminated are the former and the structureless is the latter. The platy fragmentation displays parallel-laminated arenaceous marls, and slabby parting that is flaky in shape is shown in the nonarenaceous one. Arenaceous marls appear in the bottom of nonarenaceous ones. 

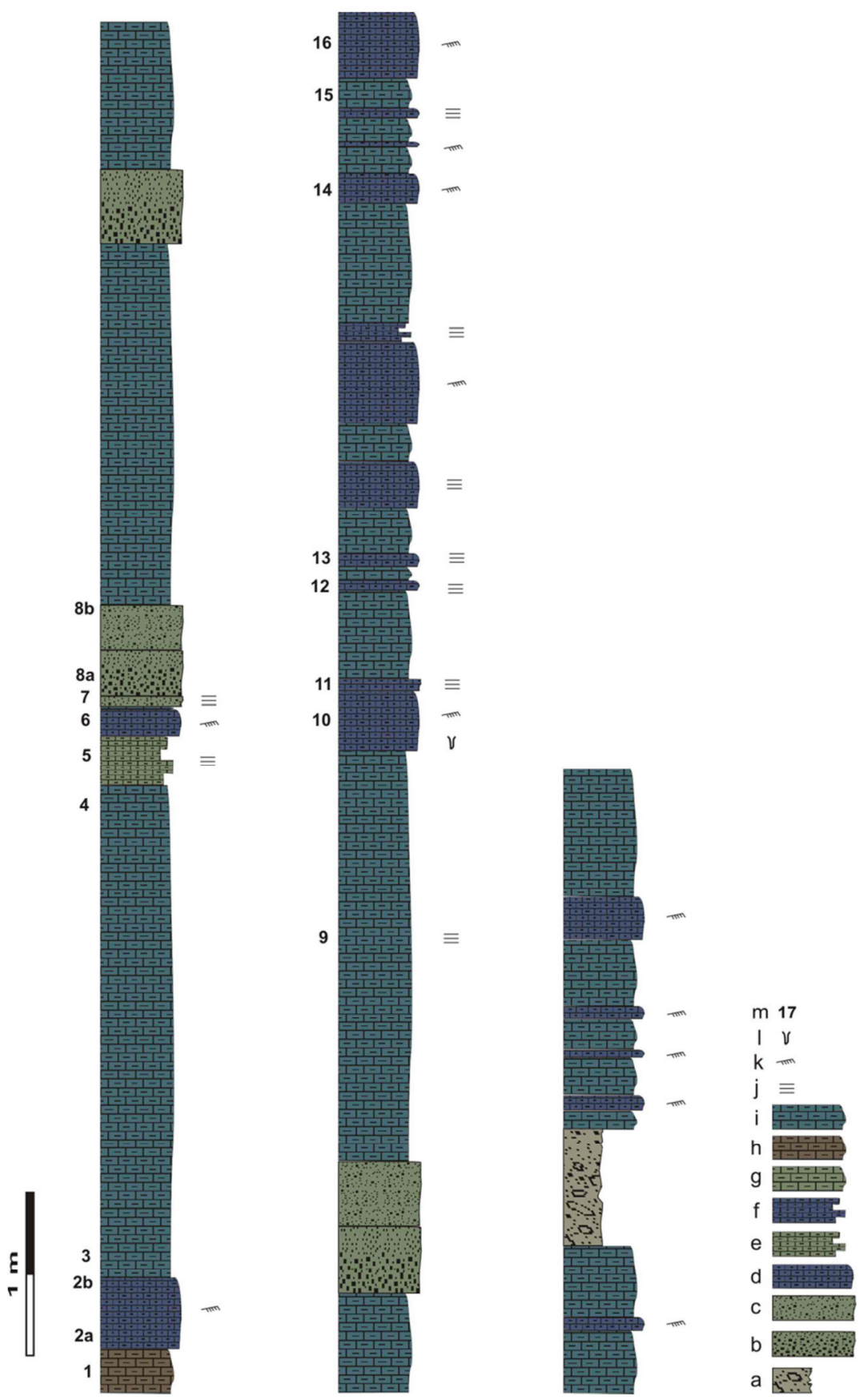

Fig. 13. Lithology of the Budzów Beds (section I) exposed along the Droździna Stream (Budzów). Explanations: $\mathrm{a}$ - slumps; $\mathrm{b}-\mathrm{c}$ - sandstones: $\mathrm{b}$ - graded; $\mathrm{c}$ - parallel-laminated; $\mathrm{d}$ - arenaceous marls cross-laminated; e-f - arenaceous marls parallel-laminated: e - dark olive; f - nevy-grey; g-i - nonarenaceous marls: $g$ - dark olive; $h$ - brown; $\mathrm{i}$ - dark bluish-greenish-grey; $\mathrm{j}$ - parallel lamination; $\mathrm{k}$ - cross-lamination; 1 - burrows; $\mathrm{m}$ - samples. 


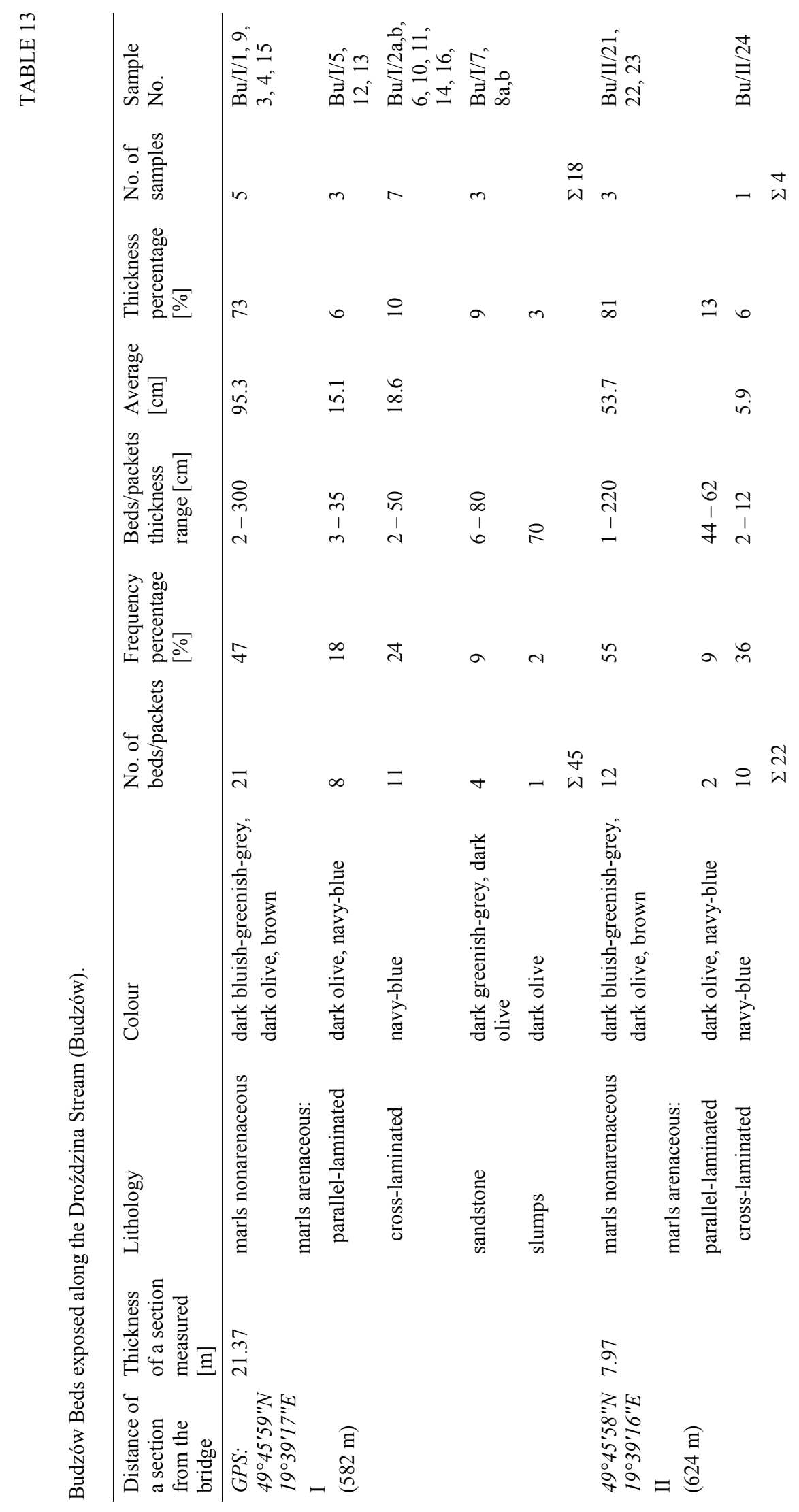




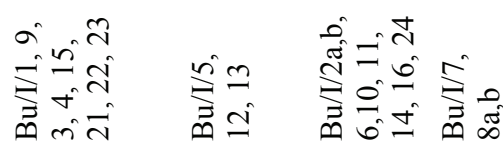

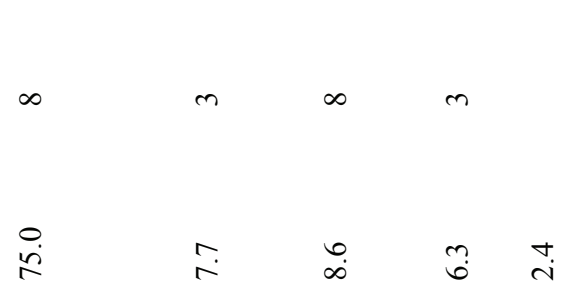

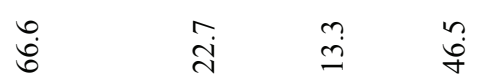

$\begin{array}{lllll}8 & 1 & 0 & 0 \\ -1 & 1 & 1 & 1 \\ 1 & m & n & 0\end{array}$

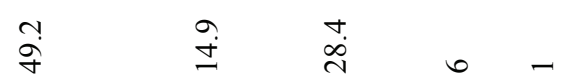

$m \quad 2 \quad+-\overleftarrow{6}$

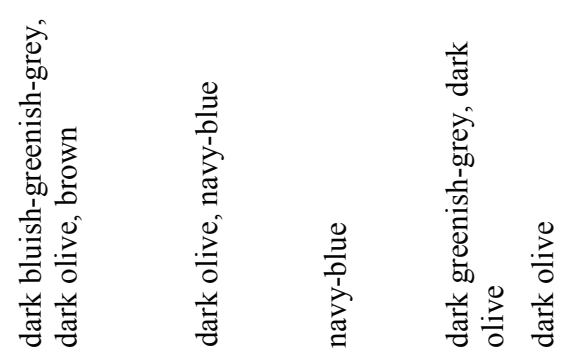

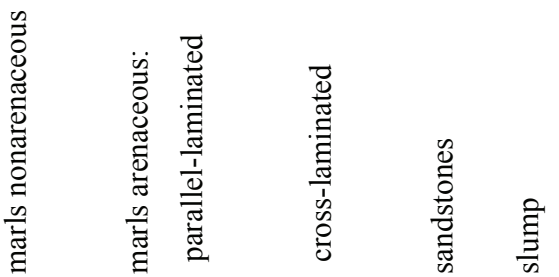

$\stackrel{+}{\stackrel{4}{2}}$

苛 


\section{Detailed outcrop descriptions}

The nonarenaceous marls are structureless, but locally reveal the presence of faint, very thin (about $1 \mathrm{~mm}$ ) parallel, slightly wavy, and lenticular laminae defined by silt-sized grains. These marls are bluish-greenish-gray, occasionally dark olive and brownish in colour. They are very hard, splity, showing flaky fragmentation. Parting planes are stained with reddish-brown, orange-brown and olive discolouration. Freshly broken conchoidal fragments are fairly sharp-edged. The thickness of nonarenaceous marl beds range from $1-$ $300 \mathrm{~cm}$, but it is largely decimetre-sized and about 2 meters thick.

The arenaceous marls are represented by two varieties: parallel-laminated and crosslaminated. They are navy-blue, occasionally dark olive in colour and there is olive discolouration on weathered surfaces. The arenaceous marls are hard and splitty. Some of them exhibit laminae-defined parting, but massive, very hard, chert-like varieties occur as well. Very hard arenaceous marls sometimes disintegrate after hammering into conchoidal fragments with sharp edges. This type of bed is fractured. Abundant, thin, vertical cracks are sometimes filled with calcite. The thickness of arenaceous marl beds range from 2 $62 \mathrm{~cm}$, but it is largely centimetre-sized. The undersurfaces of arenaceous marls are sometimes covered by fine hieroglyphs and parting planes exhibit very fine mica flakes.

The sandstones are dark green, occasionally dark olive in colour, usually well-lithified, parallel laminated and graded bedded. The parallel-laminated sandstones are very fine- and fine-grained, while the graded bedded variety contains medium-sized grains at the base. The former often show platy fragmentation and the parting planes contain abundant mica flakes. The thickness of sandstone beds varies from $6-80 \mathrm{~cm}$. Their undersurfaces are often covered by numerous hieroglyphs.

Nonarenaceous marls are the most common in the profiled Budzów Marls (49.2\%) and distinctly dominant in thickness (75\%), due to the thickest beds. Arenaceous marls are also fairly common, particularly the cross laminated variety $(28.4 \%)$ but their thickness percentage is low (Table 13). Sandstones (with frequency and thickness percentages of $6 \%$ and $6.3 \%$ respectively) and deposits of submarine slumps are of secondary importance.

\section{Summary}

According to the present studies, the Budzów Beds exposed in the Droździna Stream in Budzów are represented mainly in the form of thick packages of navy-blue-greenish hard, splity nonarenaceous marls, interbedded with thin-beds of navy-blue, very hard arenaceous marls that are generally cross- and, less frequently, parallel laminated. Much less common are medium beds of fine-grained, parallel laminated and graded bedded green-gray sandstones and brownish-gray products if submarine slumps containing fragments of marly beds (Fig. 13; Table 13).

The analysis of the profiled Budzów Marls has shown that the beds of nonarenaceous marls usually appear above the beds of arenaceous ones (Fig. 13) and are locally separated by sandstone beds and deposits of submarine slumps. Arenaceous members of bipartite beds are usually cross- or, less commonly, parallel-laminated. Locally, an arenaceous parallel laminated marl bed is overlain by a bed of cross laminated one.

It should be emphasize that the profiled Zembrzyce and Budzów Beds are lithologically very similar. Their main components are very thick beds of nonarenaceous marls. However, the Budzów Marls are more hard and more commonly display platy fragmentation, whilst 
the Zembrzyce Marls have a loaf-like parting. The Budzów Beds are generally darker, usually bluish-greenish gray in colour, whilst those of the Zembrzyce are olive and brown. The Zembrzyce Beds contain more sandstones. Moreover, in the profile of Budzów, numerous fissures filled with calcite are visible in beds of arenaceous marls and sandstones, as well as some dislocations of beds.

\section{Leluchów Marls}

Geological background and previous works

The Leluchów Marls (Table 1; Figs. 1, 2) occur in the Magura Unit. They appear among the youngest series of inner peri-Pieniny tectonic-facies zone of the Magura Unit called the Krynica Zone.

The Leluchów Marls belong to calcareous deposits that appear in the final Eocene stage in the Outer Carpathian basin. They were distinguished as the Globigerina marls (Blaicher, Sikora 1967) and subsequently considered to represent the stratigraphic equivalent of the Sub-Menilite Globigerina Marls (Birkenmajer, Oszczypko 1989; Oszczypko 1996; Leszczyński 1997). This name is traditionally applied to pelagic and hemipelagic deposits consisting predominantly of planktonic foraminifers (Olszewska 1983, 1984; Olszewska, Malata 2006), closing eocenic sedimentation in all basins of the Outer Carpathians, except in the northern part of the Magura Basin (Bieda et al.1963). It is generally accepted that, in the Magura Basin, the Globigerina Marls were deposited only in the Krynica, Bystrzyca and, locally, the Rača Zones (Oszczypko 1992; Oszczypko-Clowes 1998; Oszczypko, Oszczypko-Clowes 2006). They are characterized as fairly hard, creamy and greenish marls, several meters to a dozen meters thick, and as an important chronostratigraphic horizon (Van Couvering et al. 1981). In general, the Sub-Menilite Globigerina Marls are defined as a lithologically variable rock complex, dominated by above described marls. The Globigerina Marls are underlain by Upper Eocene Green Shales or their equivalents and overlain by Oligocene Menilite Beds (Leszczyński 1997).

The Leluchów Marls (Uppermost Upper Eocene - Lowermost Lower Oligocene) in the formal subdivision of Birkenmajer and Oszczypko (1989) are distinguished as the member and assigned to the Malcov Formation (Table 2). Wójcik et al. (1996) distinguished these marls as a formation and named them the Znamirowice Globigerina Marls. This is a common definition for the Globigerina Marls occurring in all tectonic units of the Flysch Carpathians.

The thickness of the Leluchów Marls is about $4 \mathrm{~m}$ (Birkenmajer, Oszczypko 1989). They differ lithologically from typical Globigerina Marls (Oszczypko 1996). According to the references, the sequence of the Leluchów Marls is dominantly red and green coloured. Their colour varies from red in the lower part to a gray-green, olive and gray upsection (Blaicher, Sikora 1967; Birkenmajer, Oszczypko 1989; Oszczypko et al. 1990; Oszczypko 1996). In Leszczyński's (1997) opinion, numerous burrows occur in red marls, and among green marls there appear intercalations of yellow-green and dark brown marls, calcareous and noncalcareous green and dark gray shales, as well as of very thin-bedded sandstones.

The Malcov Formation, including the Leluchów Marls, is underlain by a series of Middle-Upper Eocene Magura Formation. In the Krynica Zone, the Magura Formation is represented by three members: the Piwniczna Sandstones, Mniszek Shales and Poprad 
Sandstones of a total thickness of 2000-2500 m (Oszczypko et al. 1990; Bromowicz 1992a). No Poprad sandstones were found to occur near Leluchów. Moreover, there is lack of contact between the Leluchów Marls and the Magura Formation series (Mniszek Shales and Piwniczna Sandstones). In Leluchów the marls in question are directly underlain by green Upper Eocene calcareous shales, about $4 \mathrm{~m}$ thick (Blaicher, Sikora 1967). In the opinions of Oszczypko and Oszczypko-Clowes (2006), these shales initiated sedimentation of the Malcov Formation. It should be emphasized that the Green Shales usually underlie the Globigerina Marls and represent a characteristic facies of Late Eocene deposits in nearly all the units of the Outer Carpathians (Bieda et al. 1963). In the Krynica Zone, the Malcov Formation is considered to be an equivalent of the Poprad Sandstone Member (Birkenmajer, Oszczypko 1989). It should be noted that near Leluchów a tuffitic intercalation, about $10 \mathrm{~cm}$ thick, was found in the Mniszek Shales, correlated to tuffites in Polany (Oszczypko-Clowes 2001). The thickness of the Mniszek Shales in Leluchów amounts to $25 \mathrm{~m}$ (Oszczypko, Oszczypko-Clowes 2006).

According to Birkenmajer and Oszczypko's scheme (1989), the Leluchów Marls are overlain by Oligocene series of the Malcov Formation: the Smreczek Shales and sandstoneshaly Malcov Beds. The former are represented by shales of Menilite type, about $20 \mathrm{~m}$ thick. They contain several tuffitic intercalations, correlated to Gąsiory tuffites (36.4 \pm 1.4 Ma). The Smreczek Shales are overlain by a complex of the Malcov Beds, about $40 \mathrm{~m}$ thick (Blaicher, Sikora 1967; Oszczypko et al. 1990). In Birkenmajer and Oszczypko's (1989) subdivision, this series is connected to one member assigned to the Malcov Formation and is called the Smreczek Shales Member. Wójcik et al. (1996) propose to distinguish two members: the Smreczek Shales Member and the Malcov Members. The Malcov Formation series is the youngest of the Magura Unit in the Krynica Zone.

\section{$\underline{\text { Results of fieldwork }}$}

The Leluchów Marls were profiled and sampled in Leluchów, at the right Poprad bank, near the road to the orthodox church. This outcrop is considered to represent stratotype one and was studied several times by many authors (Blaicher, Sikora 1967; Birkenmajer, Oszczypko 1989; Oszczypko et al. 1990; Oszczypko 1996; Leszczyński 1997; OszczypkoClowes 2001). In this outcrop, located along the country road, which was about $50 \mathrm{~m}$ long in 1999, the beds are dipping at low angle to the NE and E (90/30, 20/33). The sequence, which is about 3 meters thick, has been described and sampled. 8 samples from 8 beds were collected for detailed studies (Table 14, Fig. 14).

\section{Lithologic classification of marls}

The examined marls are soft, nonarenaceous, thin-medium bedded, slabby parting, rich in trace fossils, structureless and parallel-laminated. They occur in green and red varieties with variable tint, but spotty marls are also visible. The green marls are sea-green, dark green and olive (brown-green), whilst red ones are orange-brown and red-brown (chocolate) in colour. The green marls occur at the bottom of this profile and appear among red, variegated and chocolate varieties. The chocolate marls close this profile (Fig. 14; Table 14). 


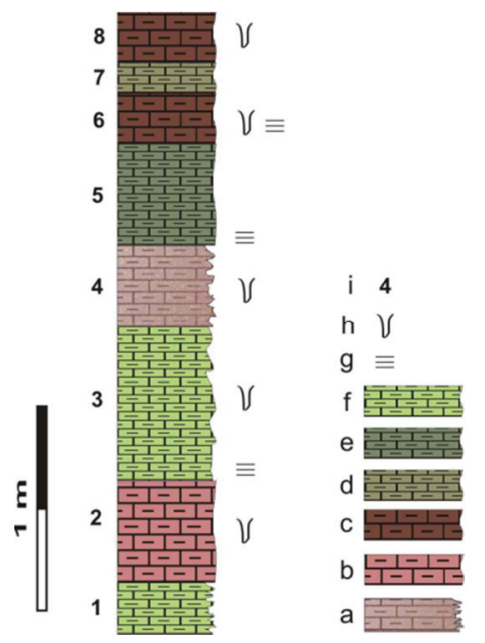

Fig. 14. Lithology of the Leluchów Marls exposed along a path close the church in Leluchów.

Explanations: $\mathrm{a}-\mathrm{f}$ - marls: $\mathrm{a}$ - variegated; $\mathrm{b}$ - red; $\mathrm{c}$ - brown; $\mathrm{d}$ - olive; $\mathrm{e}-$ dark green; $\mathrm{f}-$ green; $\mathrm{g}$ - parallel lamination; $\mathrm{h}$ - burrows; $\mathrm{i}$ - samples.

TABLE 14

Leluchów Marls exposed in Leluchów.

\begin{tabular}{llllll}
\hline $\begin{array}{l}\text { Outcrop } \\
\text { located along } \\
\begin{array}{l}\text { a path close } \\
\text { the church }\end{array}\end{array}$ & $\begin{array}{l}\text { Width of } \\
\text { a packets } \\
\text { exposure } \\
{[\mathrm{m}]}\end{array}$ & $\begin{array}{l}\text { Packets } \\
\text { thickness } \\
{[\mathrm{m}]}\end{array}$ & Colour & $\begin{array}{l}\text { Sedimentary } \\
\text { structures }\end{array}$ & $\begin{array}{l}\text { Sample } \\
\text { No. }\end{array}$ \\
\hline $\begin{array}{l}G P S: \\
49^{\circ} 18^{\prime} 3^{\prime \prime} N\end{array}$ & 0.5 & 0.25 & green & burrows & $\mathrm{Le} / \mathrm{I} / 1$ \\
$20^{\circ} 55^{\prime} 59^{\prime \prime} E$ & 1 & 0.5 & red & be/I/2 \\
& 1.5 & 0.75 & green & burrows & $\mathrm{Le} / \mathrm{I} / 3$ \\
(outcrops is & 0.8 & 0.4 & variegated (red-green) & burrows & $\mathrm{Le} / \mathrm{I} / 4$ \\
50 m long) & 1 & 0.5 & dark green & Le/I/5 \\
& 0.5 & 0.25 & dark brown & burrows & $\mathrm{Le} / \mathrm{I} / 6$ \\
& 0.3 & 0.15 & olive & burrows & $\mathrm{Le} / \mathrm{I} / 7$ \\
& $>0.5$ & $>0.25$ & light brown & & $\mathrm{Le} / \mathrm{I} / 8$ \\
\hline
\end{tabular}

\section{Detailed outcrop descriptions}

The green marls are structureless, but occasionally show faint stringers several millimeters thick that are defined by silt-to fine sand-sized grains. Four packages of green coloured variety were distinguished. Bright green and strong green colours and variable parting were observed. The green marls occurring at the bottom of the sequence are seagreen in colour, fairly hard, slabby parting with maroon discolouration on parting surfaces. They are similar to the green marls appearing upsection, among red and variegated 
varieties. These green marls are sea-green, fairly hard and with slabby parting as well, but with red discolouration and trace fossils on the parting surfaces. The green marls that occur among the variegated and chocolate varieties are dark green, hard, show platy fragmentation with rough parting surfaces. The green marls developed toward the section, between packages of chocolate variety, display similar platy fragmentation but olive tint.

The red marls are the most characteristic component of the Leluchów Marls. These marls, which occur in the lower part of the profile, are redbrick coloured, hard, platy parting, structureless. Numerous bioturbations are visible on some parting surfaces. Red marls that appear in upper part of the profile are darker and have green spots. Above the spotty marls, there are two packages of red-brown ones (chocolate marls), separated by green varieties (Fig. 14). The lower package of chocolate marls is faintly, irregular parallel laminated. The laminae are thinner than $1 \mathrm{~mm}$ and defined by slight grain-size difference and cream colouration as well. The background has a reddish brown tint in different brightness settings. These marls are hard, split, slabby parting with flat parting surfaces and broken into blocks. On the parting planes traces of organic remains and bioturbations are visible. The upper package of chocolate marls is light coloured, structureless, slabby parting along flat parting planes and is less hard.

The proportions of green and red varieties are similar (about 50\%) and in thickness the former slightly dominate (54\%). Marls that are orange-brown in colour and chocolate marls occur in similar proportions ( $25 \%$ each) but in the profile the former variety dominate ( $29.5 \%$ versus $16.4 \%)$. Moreover, they are lithologically less diversified that the chocolate marls (Table 14; Fig. 14).

\section{Summary}

According to the analysis of the Leluchów Marls section, which crops out in a country road-cutting above an orthodox church at Leluchów (Table 14), these rocks can be characterized as interbedding thin and medium beds of soft, nonarenaceous varieties of red and green marls which became darker upsection. These marls are structureless, with streaks of coarser grains locally that are occasionally parallel-laminated and often bioturbated.

\section{Niwa Marls (marls from the Malcov Beds)}

\section{Geological background and previous works}

The Niwa Marls (marls from the Malcov Beds) occur in the Magura Unit (Table 1; Figs. $1,2)$ within sandstone-shaly member of the Malcov Beds of Nowy Targ facies, exposed in Niwa near Nowy Targ (Cieszkowski, Olszewska 1986). The Malcov Beds (Late EoceneEarly Oligocene) are distinguished in formal stratigraphic subdivision as a formation (Birkenmajer, Oszczypko 1989) (Table 2).

The thickness of the Malcov Beds in the Nowy Targ facies (Uppermost Eocene-Lower Oligocene?) amounts to $600-800 \mathrm{~m}$. They are characterized as fine-rhythmic sandstoneshaly flysch with intercalations of slabby parting claystones, marls and thick-bedded Magura Sandstones in muscovite facies. Soft, olive and yellow-beige marls form intercalations that are 1-2 m thick (Cieszkowski, Olszewska 1986).

In the Nowy Targ region the Malcov Beds are underlain by the Magura Sandstones in muscovite facies, up to over $1000 \mathrm{~m}$ thick (Cieszkowski, Olszewska 1986). In the 
stratotype area in the Malcov region in Slovakia, the Malcov Beds overlie the Menilite Shales, which are underlain in turn by the Globigerina Marls and the Variegated Shales.

The Malcov Beds in the Nowy Targ facies are the youngest lithostratigraphic unit of the Magura Unit in Nowy Targ region. They are considered to represent the chronostratigraphic equivalent of the Budzów Beds and partly the Magura Sandstones in glauconitic facies.

\section{Results of fieldwork}

The marls in the Malcov Beds of Nowy Targ facies, which were exposed in 1976-77 in Niwa near Nowy Targ during construction of the Kraków - Zakopane road, were described by Cieszkowski and Olszewska (1986). These authors have published a profile of the Malcov Beds, $60 \mathrm{~m}$ thick. The present author has profiled these beds in 1999, in orographically right bank of the Klikuszowa Stream in Niwa. This outcrop is localized about $50 \mathrm{~m}$ from the passage of the Kraków - Zakopane road. From the profile of the Malcov beds, which are about 5.5 thick, consisting of 20 beds of marls, sandstones and shales, 9 samples were collected for detailed studies (Table 15; Fig. 15).

\section{Lithologic classification of marls}

Two varieties of marls were distinguished:

1. green, soft, nonarenaceous, parallel-laminated and structureless, penetrated by burrows, slabby parting and thin- to medium-bedded;

2. gray, hard, arenaceous, cross-laminated, massive and thin-bedded.

\section{Detailed outcrop descriptions}

The green, soft, nonarenaceous marls show an olive tint. Faint, parallel lamination that is defined by thin (approximately $1 \mathrm{~mm}$ in thickness) stringers of silt-sized grains, is locally destroyed by burrowing. These marls are slabby parting, show flaky fragmentation and are stained brown to black on parting planes. The average thickness of green marl packages is $24 \mathrm{~cm}$ (Table 15).

The gray, hard, arenaceous marls show a bluish tint. They consist of co-set of faint cross-laminae marked by colour intensity. After hammering, these marls are split and reveal sharp-edged flaky fragmentation. The average thickness of bluish-gray marl beds is $10 \mathrm{~cm}$.

The sandstones are bluish-gray, graded bedded and well-lithified. They are fine-medium grained and contain mica flakes. When weathered they become yellow-brown.

The shales are both calcareous and noncalcareous. The former are soft, bluish-gray, some arenaceous, micaceous and fine fissile. Noncalcareous shales are olive and fairly hard. When weathered become ginger.

Nonarenaceous soft marls are the most common in this profile $(35 \%)$, but their thickness frequency amounts to $30.9 \%$ (Table 15). Their beds are from 4-60 cm thick. Relatively less abundant sandstones (frequency percentage $15 \%$ ) occur in thicker beds from 40-200 cm. Therefore, their thickness percentage in this profile is the highest $(53.4 \%)$. Arenaceous hard marls are fairly common (25\%) but their thickness percentage is low $(9.6 \%)$ because of low thickness of beds $(5-15 \mathrm{~cm})$. The beds of calcareous shales are very thin $(2-3 \mathrm{~cm})$, whilst those of noncalcareous ones 3 to $20 \mathrm{~cm}$ thick. 


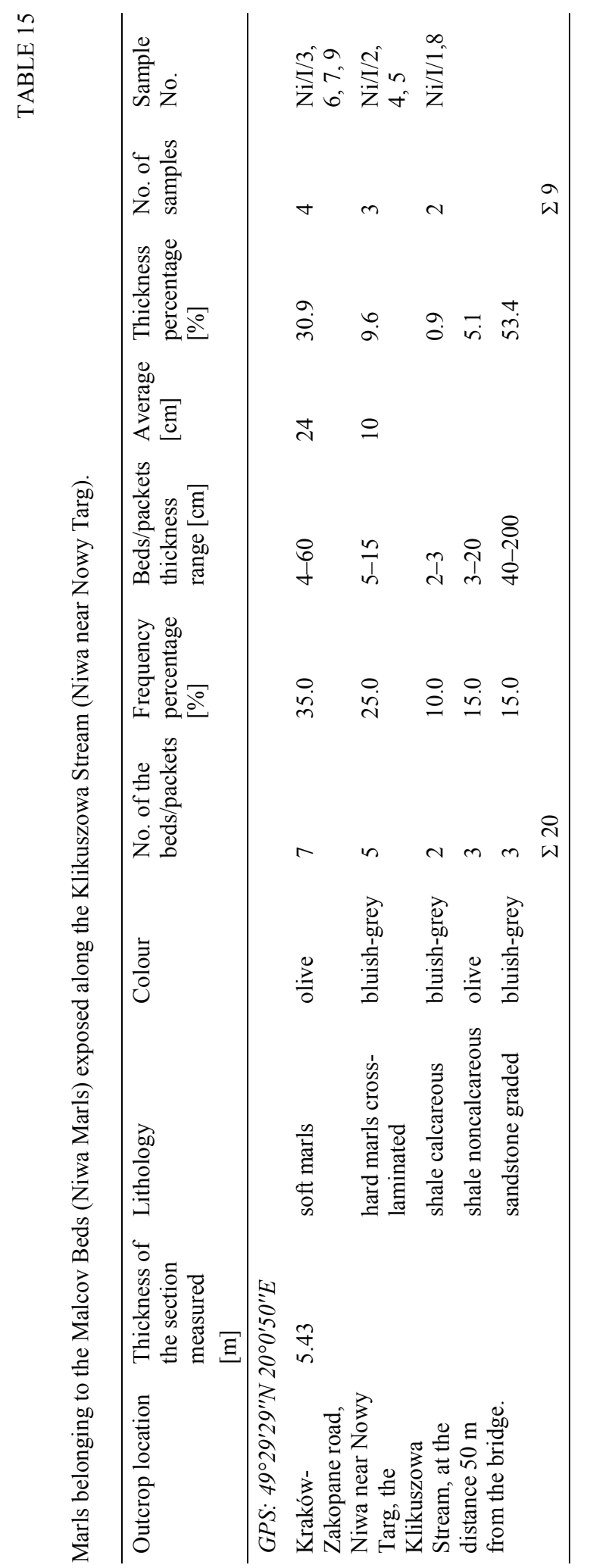




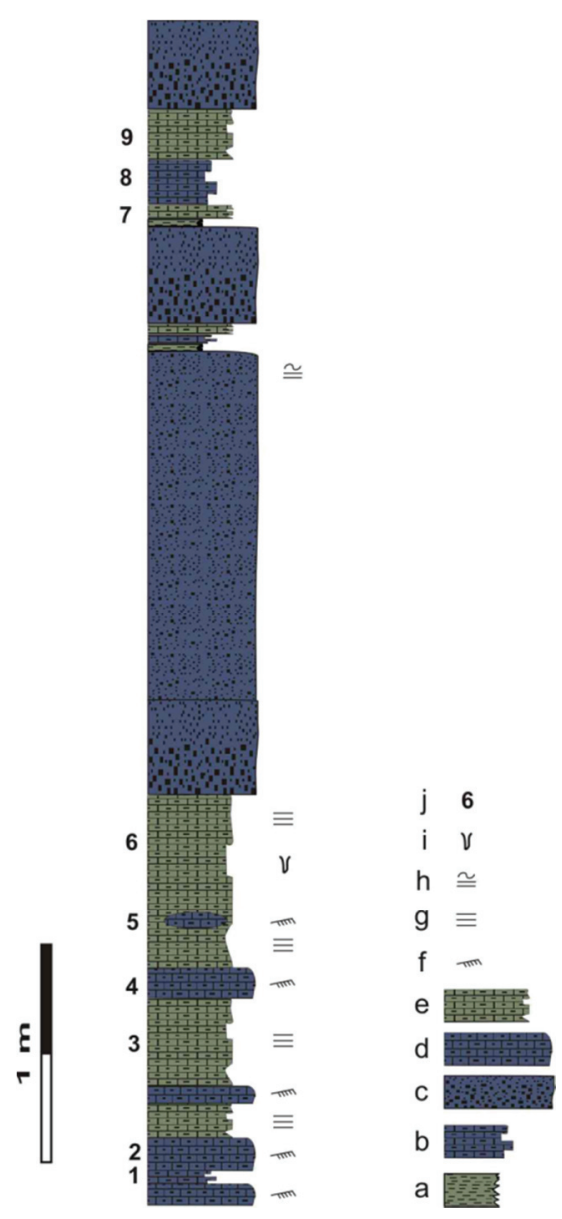

Fig. 15. Lithology of the marls occurring within the Malcov Beds exposed along the Klikuszowa Stream in Niwa near Nowy Targ (Niwa Marls).

Explanations: $\mathrm{a}-\mathrm{b}$ - shales: $\mathrm{a}$ - noncalcareous; $\mathrm{b}$ - calcareous; $\mathrm{c}$ - sandstones; $\mathrm{d}$ - hard marls; $\mathrm{e}$ - soft marls; $\mathrm{f}$ - cross lamination; $\mathrm{g}$ - parallel lamination; $\mathrm{h}$ - parallel-wavy lamination; $\mathrm{i}$ - burrows; $\mathrm{j}$ - samples.

\section{Summary}

The present studies of marls from the Malcov beds described and measured in the Niwa locality (Niwa Marls) have shown that bluish-gray arenaceous marls in this profile usually underlie the olive nonarenaceous ones. The latter locally appears above the shale. Sandstone beds are overlain by noncalcareous shale and, subsequently, calcareous shale and nonarenaceous marl (Fig. 15). In composite marl beds, the arenaceous marl division/ nonarenaceous mud division thickness ratio (sand/mud thickness ratio) varies from 1:1 to 1:12 (Fig. 15). 


\section{Grybów Marls}

\section{Geological background and previous works}

The Grybów Marls (Table 1; Fig. 1, 2) occur in the Grybów Unit, appearing in tectonic windows in the Magura Unit. The Grybów Marls are a very characteristic component of the Grybów series. The Grybów Unit is considered to represent the western continuation of the Dukla Unit and they both are assigned to the Fore-Magura Units sensu lato (Koszarski 1985c). Tectonic windows, exposing the Grybów Unit, are located in marginal part of the Magura Unit. The appearing elements of the Grybów Unit are tectonically intensely deformed and are often folded together with rocks of Magura Unit. Moreover, the Grybów Unit is characterized by considerable facies variability. This refers particularly to Oligocene series, which the Grybów Marls belong to (Sikora 1970; Cieszkowski 1992). It is considered that the locus typicus of these marls is exposed in the Grybów Tectonic Window (Bieda et al. 1963).

The Grybów Marls (Oligocene) were distinguished by Uhlig (1888) in the Grybów Tectonic Window and called the Grybów Shales. In this author's opinion they represent an equivalent of the Menilite Beds. Kozikowski (1956) and Ślączka (1973a) call them the Grybów Beds and the latter author in formal subdivision (Ślączka, Kamiński 1998d; Oszczypko-Clowes, Ślączka 2006) distinguishes them as the Grybów Marl Formation and as the equivalent to the lower part of the Menilite Beds. It should be emphasized that in the Ropa Tectonic Window, Sikora (1970) has distinguished two lithological types of Menilite Beds composed of Grybów-type marls: the Sub-Grybów Marls and the Grybów Shales. Moreover, in this author's opinion, these both lithologic types of Menilite Beds with marls of Grybów- type and the Menilite Shales (distinguished as the third lithologic type of Menilite Beds) are mutually substituting. In this subdivision, the Grybów Marls vel the Grybów Shales are a member of the Menilite Formation (Table 2).

The thickness of the Grybów Marls is variable and estimated to be up to $400 \mathrm{~m}$ (Bieda et al. 1963). The Grybów Marls are characterized by various authors (Bieda et al. 1963; Świdziński 1963; Ślączka 1973a) as black, brown and gray, hard calcareous, partly arenaceous shales, intercalated with usually glauconitic sandstones. In upper part of the profile there are ginger layers and lenses of ferrous dolomites (Narębski 1957) and black cherts.

The Grybów Marls are underlain by the Hieroglyphic Beds with the Green Shales and the Globigerina Marls in the top. In the Grybów Tectonic Window this series occurs in Strzylawka Scale and is exposed by the stream bearing the same name (Koszarski 1985d).

The Grybów Marls are overlain by a rock series previously assigned to the Krosno Beds (Świdziński 1963), now considered to represent shaly-sandstone, distal facies equivalent of the Cergowa Beds from the Dukla Unit. Consequently, the Grybów Marls are correlated to the Sub-Cergowa Marls (Jawornik Marls) that occur in the Dukla Unit (Ślączka 1971, 1973a; Ślączka, Kamiński 1998d, e; Oszczypko-Clowes, Ślączka 2006).

\section{$\underline{\text { Results of fieldwork }}$}

The Grybow Marls were profiled and sampled in the stratotype area, in the valley of Strzylawka Stream in Grybów. This outcrop is described by many authors (Świdziński 1963; Ślączka 1973a; Koszarski 1985d; Ślączka, Kamiński 1998d; Oszczypko-Clowes, 
Ślączka 2006). In 1997 and 2000, the present author studied two outcrops in the Strzylawka Stream valley:

I - localized behind the second stage of fall from its outlet to the Biała River

II - in right-hand sixth tributary stream from above the Strzylawka mouth to the Biała

River.

The bottom part of the latter outcrop is discontinuous and tectonically deformed.

In outcrop I more than $9 \mathrm{~m}$ of cross-section was profiled, consisting of 7 beds visible in the stream bed and banks of the Strzylawka Stream. In outcrop II, nearly $45 \mathrm{~m}$ of crosssection was profiled, composed of 40 beds that are exposed at a distance of about $160 \mathrm{~m}$ from the outlet of a tributary stream of the Strzylawka to a waterfall formed by a thick bed $(70 \mathrm{~cm})$ of light brown glauconitic sandstone. Altogether 54 meters of cross-section, composed of 47 beds of marls, sandstones, limestones, ferrous dolomites and shales, were profiled. 32 samples were collected from these both outcrops for detailed studies (Tables 3 , 16; Fig. 16).

\section{Lithologic classification of marls}

Black to brown, nonarenaceous, soft, structureless, slabby parting marls that occur in beds of diversified thickness (from very thin to very thick) and arenaceous, hard, parallellaminated, flaggy parting, thin-bedded variety were distinguished. The arenaceous variety occurs at the bottom of nonarenaceous marl beds.

\section{Detailed outcrop descriptions}

The nonarenaceous marls are dark chocolate, nearly black, occasionally brown and graybrown in colour. Weathered surfaces exhibit whitish discoloration. The nonarenaceous marls are fairly hard, slabby parting with conchoidal fracture (flaky fragmentation). Some beds of brown and gray-brown marls show loaf-like parting. The bed thickness of the nonarenaceous marls varies from $2 \mathrm{~cm}$ to $10 \mathrm{~m}$, whereby the most frequent are those from $50-100 \mathrm{~cm}$ and from 2-10 $\mathrm{m}$. The coarsest are dark chocolate in colour. The bed thickness of the brown and gray-brown varieties is usually about $50 \mathrm{~cm}$ (Table 16; Fig. 16). The nonarenaceous marl beds that occur above sandstone beds are usually arenaceous at the bottom.

The arenaceous marls are dark brown, nearly black in colour, hard, split, showing poorly-defined fine parallel lamination that easily separates into fairly thin sheets (flaggy parting). This variety of marl forms thin beds, $2-20 \mathrm{~cm}$ thick.

The sandstones are fine-grained, well-lithified, dark gray, yellowish and friable when weathered. Structureless and faintly, parallel laminated varieties occur. The latter feature is marked by variation of colour: dark gray and yellow-gray. Mica flakes are visible on parting surfaces. Sandstone beds are $5-85 \mathrm{~cm}$ thick, whereby the beds thickness distribution is bimodal. Fissure cracks are filled with calcite.

The ferrous dolomites are graphite-gray, occasionally with a dark brown tint, and ginger when weathered. They are fine-sparitic and hard. Fe-dolomite beds are from 40-250 cm thick. Some are cracked and the fissures are filled with calcite.

The limestones are black, micritic and fine-sparitic, well-lithified, poorly marly. Their beds are $823 \mathrm{~cm}$ thick.

The shales are black, fairly hard, noncalcareous, leaf-like, papery parting with honeycoloured coatings on fissility surfaces. Their packages are thin $(2-6 \mathrm{~cm}$ thick). 


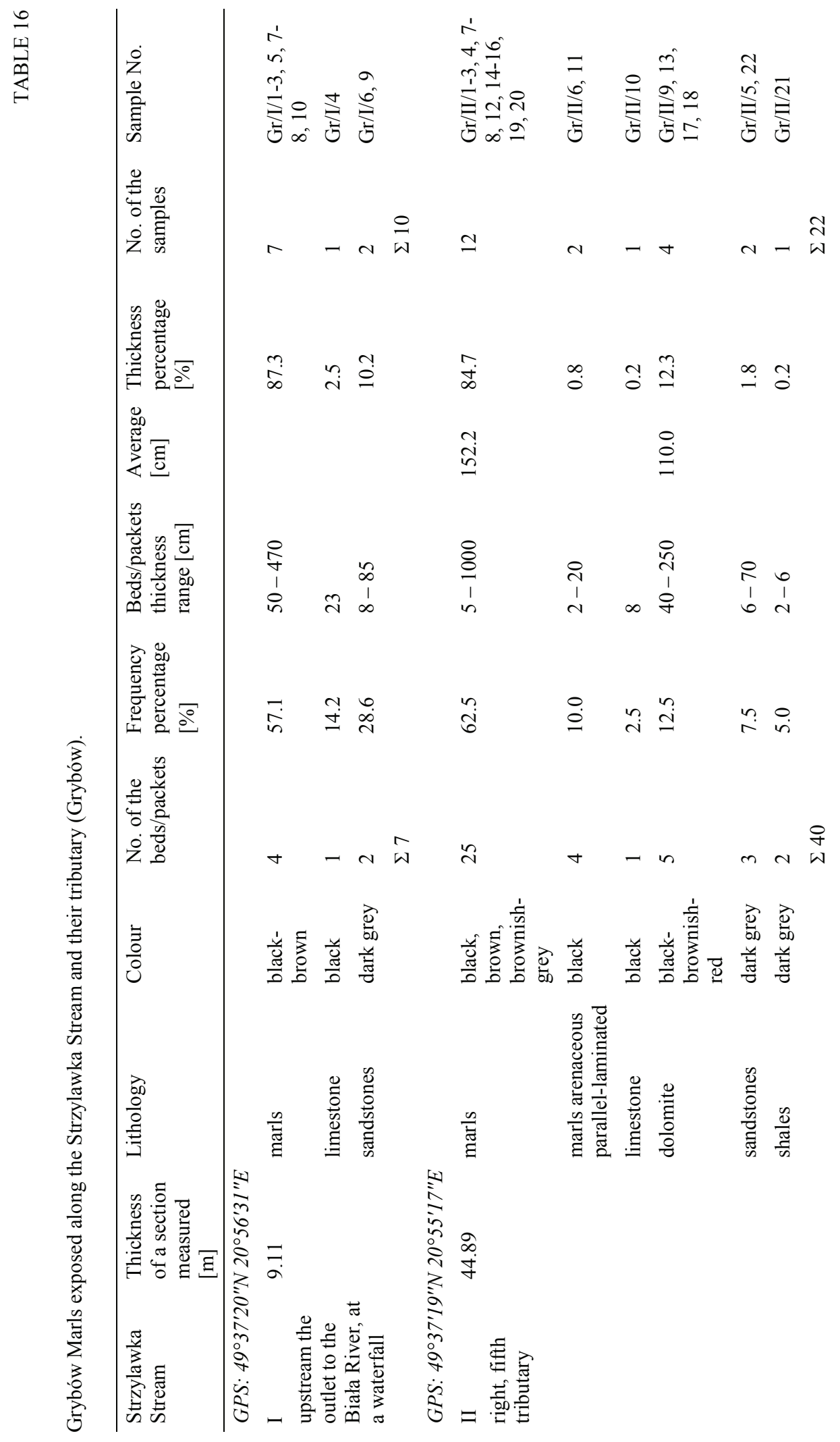




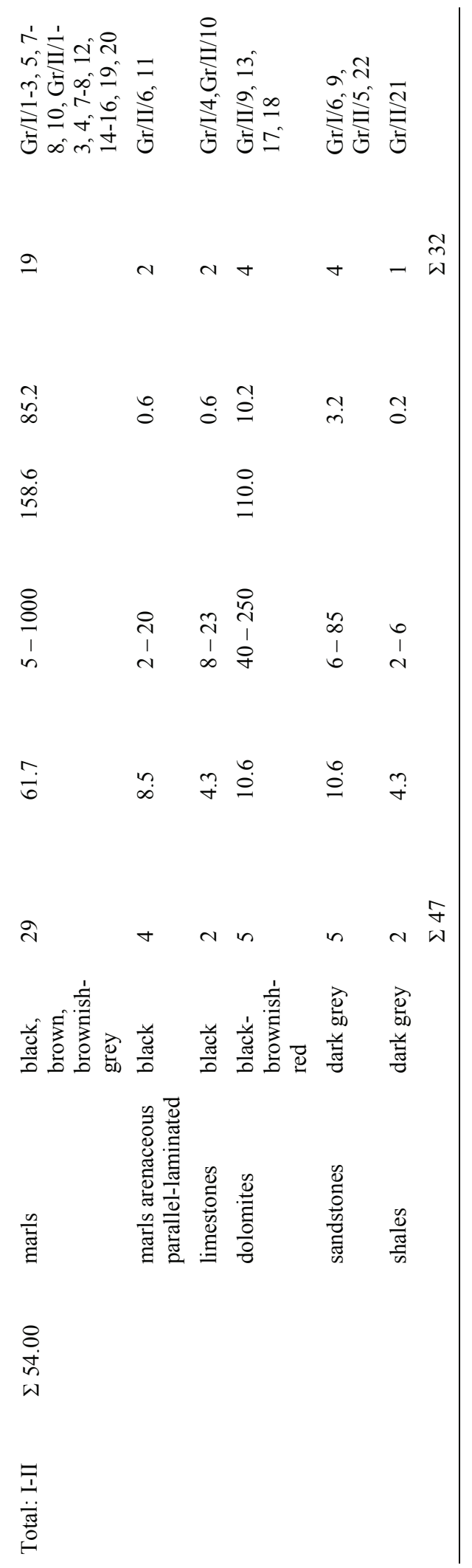




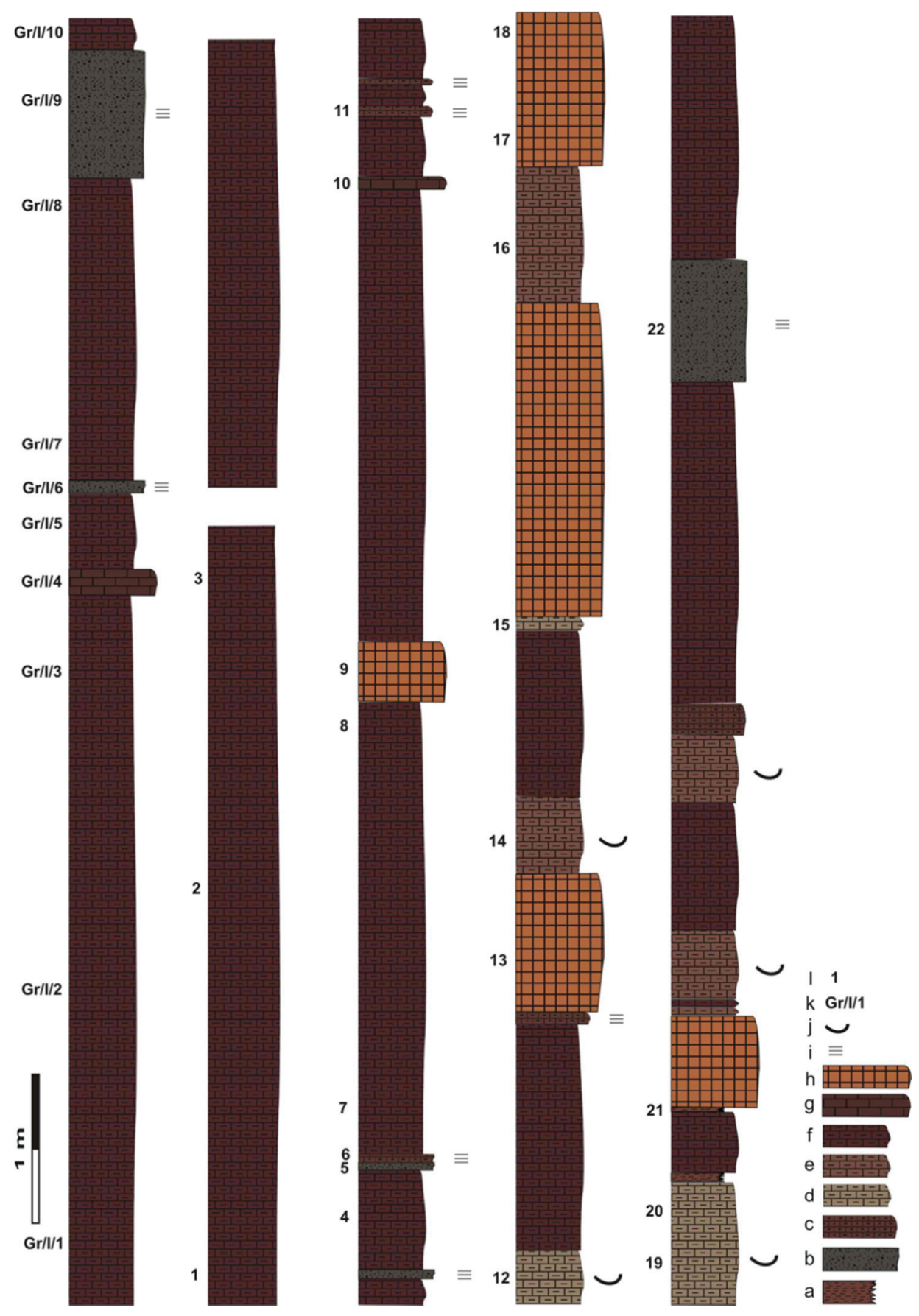

Fig. 16. Lithology of the Grybów Marls exposed along the Strzylawka Stream (Grybów).

Explanations: $\mathrm{a}$ - shales; $\mathrm{b}$ - sandstones; $\mathrm{c}$ - arenaceous marls; $\mathrm{d}-\mathrm{f}$ - nonarenaceous marls: $\mathrm{d}$ - brownish-grey; e - brown; f - black-brown; g - limestones; $\mathrm{h}$ - Fe- dolomites; i - parallel lamination; j - leaf-shaped parting; k-1 - samples: k- section Gr/I; 1 - section Gr/II. 
Nonarenaceous marls distinctly dominate (frequency percentage $-61.7 \%$ ) in the profile studied (thickness percentage 85.2\%). Their beds are often more thick than those of other rocks. Arenaceous marls are much less common in this profile $(8.5 \%$ and $0.6 \%$ respectively). The frequency percentage of sandstones and dolomites is similar (10.6\%), but the thickness percentage of dolomites is higher due to their thicker beds $(10.2 \%$ and $3.2 \%$ respectively). The amount of limestones and shales is negligible (frequency percentage $4.3 \%$, thickness percentage $0.6 \%$ and $0.2 \%$ respectively (Table 16 ).

\section{Summary}

According to the analysis of fragments of profile of the Grybów Marls, beds of nonarenaceous marls are initiated by arenaceous marls and sometimes littered by thin sandstone beds (Fig. 16). In upper part of this profile there are beds of marls with shales in the top. The sandy division of composite beds is parallel laminated, flaggy parting with platy fragmentation, and in the nonarenaceous one slabby parting with conchoidal fracture are visible. The dominance of the nonarenaceous marly member over the arenaceous one i.e. sand/mud ratio in these beds is from 1:3 to 1:25 and is usually closer to higher values. Moreover, nonarenaceous marls appear in the sequences composed of beds differing in colour (Fig. 16).

\section{Sub-Cergowa Marls (Jawornik Marls)}

Geological background and previous works

The Sub-Cergowa Marls (Table 1; Figs. 1, 2) occur in the Dukla Unit. The name "SubCergowa marls" was introduced by Ślączka (1959) for the Lower Menilite Shales (Early Oligocene), distinguished by Teisseyre (1930), underlying the Cergowa Sandstones. In the opinion of Ślączka (1977a, 1985), the Oligocene age of these marls results from their position in the profile of the Dukla Unit and micropaleontologic data. The Sub-Cergowa Marls, now formally named the Jawornik Marls (Table 2), are distinguished as a member of the Menilite Formation (Ślączka 1977a; Wójcik et al. 1996).

The Menilite Formation in the Dukla unit is underlain by the Hieroglyphic Beds with the Green Shales and the Globigerina Marls in the top. This formation differs from typical threefold Menilite Formation (Menilite Shales separated by Menilite Cherts) in the ForeDukla Zone. In the Dukla Unit it is very thick (1000-1200 m) and is lithologically very diversified both vertically and horizontally (facies) (Ślączka 1971; Koszarski 1985e). In the opinion of Koszarski (1985e), the Menilite Formation of the Dukla Unit is distinguished by the occurrence of two complexes of bituminous shales and Menilite marls with cherts, separated by sandstone-shaly Cergowa Beds. The Sub-Cergowa Marls are in the lower of these complexes, whereby their lower boundary is diachronous. Ślączka (1971) has distinguished five members in the Menilite Formation of the Dukla unit: Marls and SubCherts Shales with Mszanka Sandstones, Lower Cherts series, Sub-Cergowa Marls, Cergowa Sandstones and Shales and Cherts-bearing Menilite Shales. He emphasizes considerable lithologic variability of these members and of their thickness. In Koszarski's (1985e) opinion, the Sub-Cergowa Marls locally replace the two lowermost members of the Menilite Formation in Ślączka's (1971) subdivision. The occurrence of tuffites in the SubCherts Menilite Beds of the Skole, Silesian and Grybów Units (Ropa Tectonic Window), 
which are attributed to the Gąsiory horizon, should be noted. They were described by Koszarski and Wieser (1960) and Sikora (1970) and dated by Van Couvering et al. (1981) $34.6 \pm 1.4 \mathrm{Ma}$.

The thickness of the Sub-Cergowa vel Jawornik Marls is diversified and varies from 20 - 150 m (Ślączka 1971). They are characterized as chocolate-coloured thick-bedded, hard siliceous marls with cherts (Bieda et al. 1963; Ślączka 1971). According to Ślączka (1971, 1977a, 1985) towards the south-east and, probably towards the west too, these marls get less siliceous and less hard, lithologically resembling the Dusin Marls that are in the Transcarpathian region and the Grybów Marls known from tectonic windows, which are similar in age (Oszczypko-Clowes, Oszczypko 2011; Oszczypko-Clowes, Ślączka 2006).

The Sub-Cergowa Marls are overlain by two youngest members of the Menilite Formation: Cergowa Beds and Menilite Shales with cherts. The former are represented by sandstones and sandstone-shaly facies, are up to $350 \mathrm{~m}$ thick (Ślączka 1971) and locally $500 \mathrm{~m}$ (Koszarski 1985e). The thickness of the Chert-bearing Menilite Shales is about 300 m (Ślączka 1971).

\section{$\underline{\text { Results of fieldwork }}$}

The Sub-Cergowa Marls were profiled and sampled in 1997 in Lipowica near Dukla. This outcrop is located in marginal part of the Dukla unit, on the right side of the Dukla Barwinek road and was examined by many authors (Wdowiarz, Jucha 1963; Ślączka 1973b, 1977b; Koszarski, Koszarski 1985a). In 1997 it was a small abandoned quarry, about $20 \mathrm{~m}$ long and about $6 \mathrm{~m}$ high. The beds are dipping gently to the $\mathrm{S}(170 / 20)$. 8 meters of this profile were examined and sampled. It consists of 67 beds of marls, shales, cherts and sandstones. 53 samples were collected for detailed investigations (Tables 3, 17; Fig. 17).

\section{Lithologic classification of marls}

Dark and light brown, hard, nonarenaceous, structureless and parallel laminated marls were distinguished. The massive, non-fissile variety with chert lenses is dark and light brown, whilst showing slabby parting one is only dark brown in colour. The thickness of beds is diversified from thin to thick in dark brown marls, both massive and slabby parting varieties. On the other side light brown marls occur rather in thin beds abounding in burrows.

\section{Detailed outcrop descriptions}

The dark brown marls show a chocolate tint and light brown are coffee-coloured. The massive variety of both of them are very hard, split, with chert lenses that are up to $4 \mathrm{~cm}$ thick and $30 \mathrm{~cm}$ long and with lenses nearly black in colour, which are enriched in pyrite and an organic substance. The lenses nearly black in colour are considered to be burrows. The massive marls are dark brown in colour, break with splintery fracture and exhibit white discolouration on weathered surfaces. The thickness of their beds varies from 3.5 to $140 \mathrm{~cm}$, but usually does not exceed several tens of centimeters. Massive marls light brown in colour are harder than dark brown ones and break along irregular fracture producing fragments with smooth, black-stained surface. Burrows are dull, densely distributed and interpenetrating (burrow-mottled textures). Beds of massive light brown marls are thinner 
than the dark brown ones - their thickness varies from $1-43 \mathrm{~cm}$. Slabby parting marls showing flaky fragmentation are dark brown and softer than the massive ones of the same colour. The thickness of their beds varies from $6-35 \mathrm{~cm}$ (Table 17). In the top of marl beds, a transition into shales is visible through delicate, thin, millimeter laminae marked by darker colour. Marls are locally underlain by thin sandstone layers, several centimeters thick and in the bottom of their beds there appear lenses and streaks of fine sand-sized grains.

The shales are calcareous and non-calcareous. The former resemble marls and the latter resembles the Menilite Shales.

Calcareous shales, like the marls, are brown in colour. They are fine, fissile parting, nonarenaceous, both soft and fairly hard. They appear in the top of marly beds. The thickness of their packages varies from $0.5-39 \mathrm{~cm}$, but usually does not exceed several centimeters.

Noncalcareous shales are dark brown-ginger, spotty, fissile parting, arenaceous and brittle. Dark ginger oval and round spots and, occasionally needle forms up to $0.5 \mathrm{~mm}$ long are visible. These shales of menilite type occur in the top of some marl beds, in the upper part of the section in question. The thickness of their packages varies from $2.5-4 \mathrm{~cm}$.

The cherts are dark gray and coffee-coloured, very hard, split. They have smooth, dense and curved, conchoidal fracture surface displays waxy lustre. The thickness of the chert beds varies from $2-10 \mathrm{~cm}$.

The sandstones are calcareous, brown-ginger, fine- and very fine-grained, subtly laminated. Cross and parallel lamination is marked by change of colour and grain-size. Coarse-grains defined laminae are bright, yellowish and ginger. Laminae are up to several millimeters thick. Sandstone beds are very thin $(4-10 \mathrm{~cm})$. They often appear only as starved sandy ripples that are visible at the bottom of some marl beds.

In the examined section of the Sub-Cergowa (Jawornik) Marls, their massive variety distinctly dominates (frequency percentage $46.2 \%$, thickness percentage $72 \%$ ) and the most common are dark brown marls (31.3 and 58.0\% respectively). Calcareous shales often appear as dark brown massive marls (31.3\%), but due to low thickness of their beds their thickness percentage amounts only to $10.4 \%$. Slabby parting marls are less frequent $(6 \%)$, but form thicker beds than calcareous shales. Therefore, their thickness percentages are similar $(10.4 \%)$. Total frequency percentage of these two rock types is similar to that of massive marls and amounts to $37.3 \%$, but their total thickness percentage is much lower (21\%). The frequency percentage of cherts, noncalcareous shales (of the Menilite type) and sandstones is much lower: $6.0 \%, 4.5 \%$ and $6.0 \%$ respectively. Their thickness percentage is yet lower: $2.3 \%, 1.2 \%$ and $3.5 \%$ respectively (Table 17 ). 


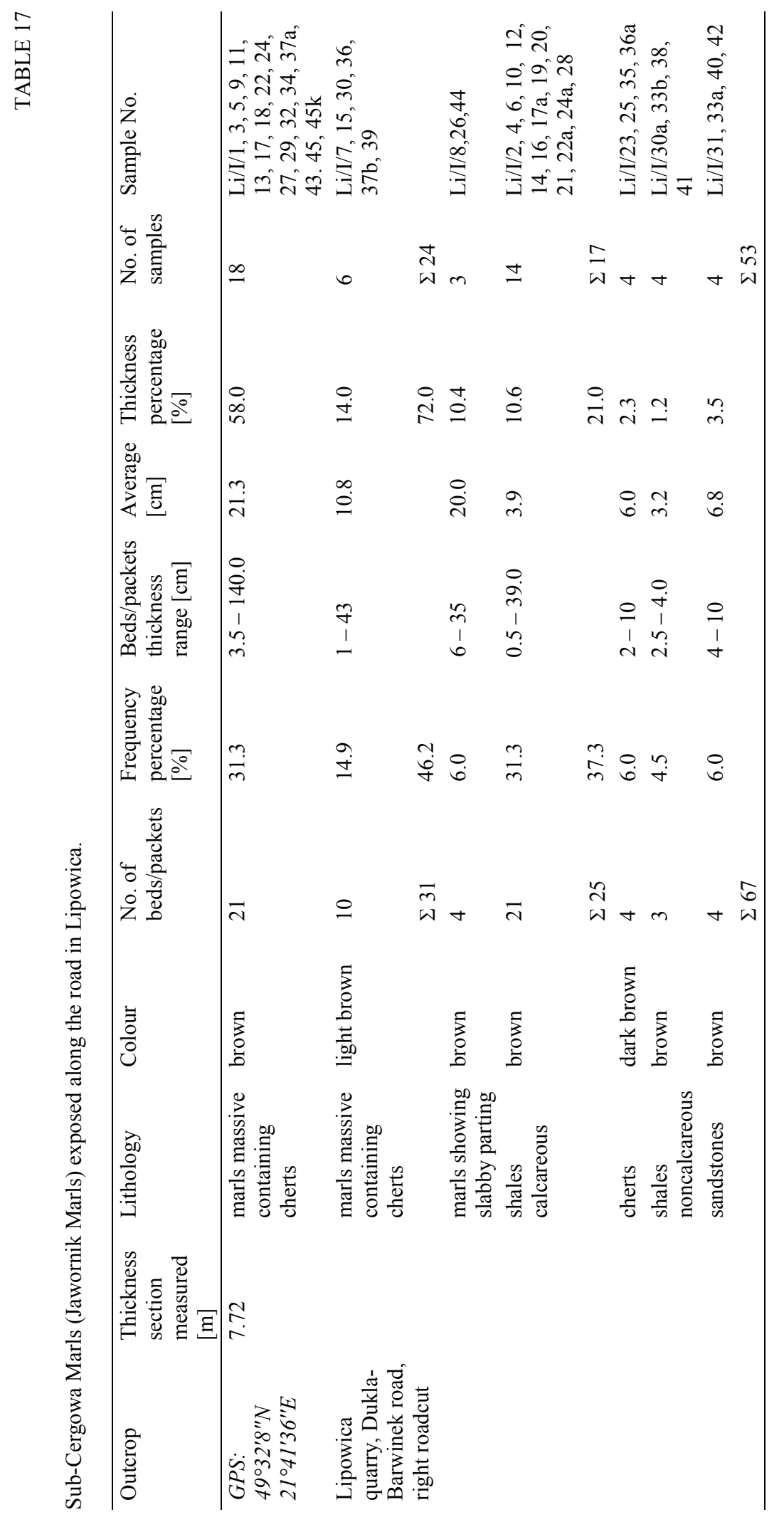




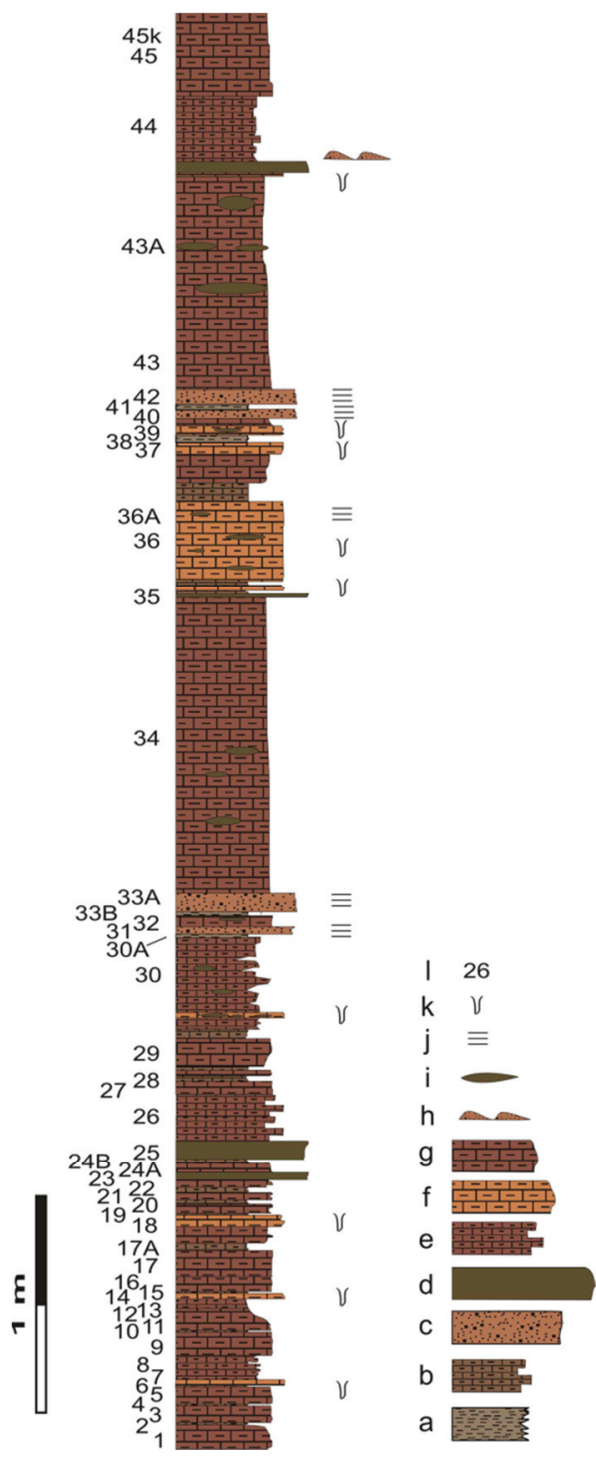

Fig. 17. Lithology of the Sub-Cergowa Marls (Jawornik Marls) exposed along the roadcut in Lipowica near Dukla.

Explanations: $\mathrm{a}-\mathrm{b}$ - shales: $\mathrm{a}$ - noncalcareous; $\mathrm{b}$ - calcareous; $\mathrm{c}$ - sandstones; $\mathrm{d}$ - bedded cherts; $\mathrm{e}$ - slabby marls; f-g - massive marls: $\mathrm{f}$ - light brown; $\mathrm{g}$ - brown; $\mathrm{h}$ - sand ripples; $\mathrm{i}$ - chert nodules; $\mathrm{j}$ - parallel lamination; $\mathrm{k}$ - burrows; 1 - samples.

\section{Summary}

According to the obtained data, the beds of Sub-Cergowa (Jawornik) Marls grade upwards into shales. Sporadically these marls are underlain by thin bed of parallel laminated sandstone, or starved sandy ripples appear at the bottom (Fig. 17). The dominance of marly division over the sandstone one (sand/mud thickness ratio) in such 
beds is in the range from 1:2 to 1:14 (Fig. 17). Faint, parallel lamination is marked in top parts of marl beds. Bioturbations are fairly common in light brown variety of marls.

\section{Dynów Marls}

Geological background and previous works

The Dynów Marls (Table 1; Figs. 1, 2) occur in the Skole Unit. The name of the Dynów Marls (Lower Oligocene) was introduced by Kotlarczyk (1966) to hard siliceous platy marls, forming locally a compact complex related mostly to the bottom part of the Menilite Beds. They occur in direct vicinity of the Menilite Cherts or directly above them. The Menilite Beds of the Skole Unit display considerable lateral and vertical variability. In the stratotype area of the Dynów Marls (Dynów region), Rajchel (1989) has distinguished: Sub-Chert Beds (up to $60 \mathrm{~m}$ thick), Chert-Marl Complex (20-60 m) and Supra-Chert Beds (up to $500 \mathrm{~m}$ ). According to Kotlarczyk (1985) the Chert-Marl Complex (bottom chert-marl package) in the Skole Unit is $40-80 \mathrm{~m}$ thick. It is possible to distinguish several well individualized members of different lateral distribution within this complex. In the formal subdivision (Table 2) proposed by Kotlarczyk (Kotlarczyk 1988; Kotlarczyk, Leśniak 1990), the whole lower part of Menilite Formation (Lower Menilite Beds) of the Skole Unit, composed of the Sub-Chert Beds and the Chert-Marl Complex, is subdivided into seven main members and five local members. The Kotów Cherts and the Dynów Marls are very widespread. Lower Oligocene age of the Dynów Marls (Rupelian) was based on nannoplankton data (vide Kotlarczyk 1985). It should be emphasized that in the Chert Beds with Siliceous Marls occurring in the Silesian Unit, Koszarski and Wieser (1963) have found intercalations of pyroclastic rocks of rhyodacitic composition (Grabownica and Krosno horizon). The thickness of the Menilite Formation in the Skole Unit is up to $700 \mathrm{~m}$ and of the Dynów Marls is up to 15-20 m (Jucha, Kotlarczyk 1961; Kotlarczyk 1966; Kotlarczyk, Leśniak 1990). The Dynów Marls are best developed in the Błażowa-Dynów region and disappear towards the NE and SW. Typical Dynów Marls are light brown, occasionally steelgray-green thin- to medium-bedded, hard, homogeneous and wavy laminated. Weathered they are beige-coloured. They contain chert lenses and sandstone intercalations. Isolated sand ripples at the base of marl beds were observed (Kotlarczyk 1985). Fish remnants were found in them. Silicified and decalcified varieties are reported to occur (Kotlarczyk 1966; Kotlarczyk, Leśniak 1990).

The Dynów Marls and the co-occurring Kotów Cherts are underlain by the Sub-Chert Shales (Beds) Member, up to $20 \mathrm{~m}$ thick. Locally they are represented by the Siedliska conglomerates (Kotlarczyk 1966, 1985). The thickness of these conglomerates, considered to represent deposits of submarine fan, is from several meters to $70 \mathrm{~m}$.

The Dynów Marls Member is overlain by the Rudawka Tractionites Member and the Huwniki Sandstones of Kliwa type Member. It should be emphasized that in the Rudawka Tractionites Member there are olistoliths of the Dynów Marls and submarine slumps containing blocks of these marls (Kotlarczyk, Leśniak 1990). The Rudawka Tractionites with slumps and olistoliths are in total up to over $100 \mathrm{~m}$ thick (usually 5-20 m). The highest members of the lower part of the Menilite Beds covering them are from several to several tens of meters thick. The thickness of Supra-Chert Beds, closing this profile of 
Menilite Formation, varies from several tens of meters to several hundred meters, depending on the thickness of Kliwa sandstones.

It should be emphasized that in the subdivision of the Menilite Formation common for the Skole, Silesian, Sub-Silesian and Dukla units, the Dynów Marls are connected with the Kotów Cherts and distinguished as the Dynów Member (Wójcik et al. 1996).

\section{Results of fieldwork}

The Dynów Marls were profiled and sampled in stratotype area near Dynów. Fieldwork was carried out in 2001, in the quarry situated on western slope of the Łysa Góra in the Straszydle Village. The route to the quarry follows a trail, which starts from the main road and the bus stop and crosses the bridge over the Lubienka Stream. This outcrop was examined by Kotlarczyk (1985). In 2001 this quarry was abandoned. The outcrop of the Dynów Marls is $50 \mathrm{~m}$ long and $30 \mathrm{~m}$ high. The rocks are deformed by two vertical faults and dip fairly steeply to the SW (200/43) and are locally dislocated by submarine slumps. Nearly $22 \mathrm{~m}$ of the profile was investigated, whereby the thickness of compact marl complex was up to $15 \mathrm{~m}$. This complex is overlies on a submarine slump, more than $2 \mathrm{~m}$ thick, and grades upsection into noncalcareous shales with thin intercalations of sandstones and cherts. Deformation caused by submarine slumps are often visible. 14 samples were collected from this outcrop for detailed studies (Tables 3, 18, Fig. 18).

\section{Lithologic classification of marls}

Light brown, hard, thin- to medium bedded, slabby and flaggy parting marls were distinguished. Four varieties of slabby marls differ in sedimentary structure are visible: with starved sandy ripples at the base, parallel laminated, with lamination defined by chert stringers and structureless. Flaggy marls are structureless (Table 18).

\section{Detailed outcrop descriptions}

The complex of Dynów Marls in the outcrop examined is composed of beds of marls differing in parting type and chert beds (Fig. 18). Thin and medium beds of slabby parting and flaggy parting marls are interbedded or beds of one variety occur in packets up to $350 \mathrm{~cm}$ and $450 \mathrm{~cm}$ thick, respectively (Fig. 18). 18 beds of marls and 4 of cherts were profiled. The thickness of marl beds and packets of marl beds varies from $1-450 \mathrm{~cm}$ and of cherts from 4-20 cm (Table 18; Fig. 18). The slabby parting marls split into platy fragments of $2-3 \mathrm{~cm}$ thick and the flaggy parting ones about $0.5 \mathrm{~cm}$. Marls are brown and beige on fresh fracture surfaces and nearly white on weathered ones. Parting planes that are dark brown in colour and spotty, exhibit frequent fine fragments of carbonized organic matter. 


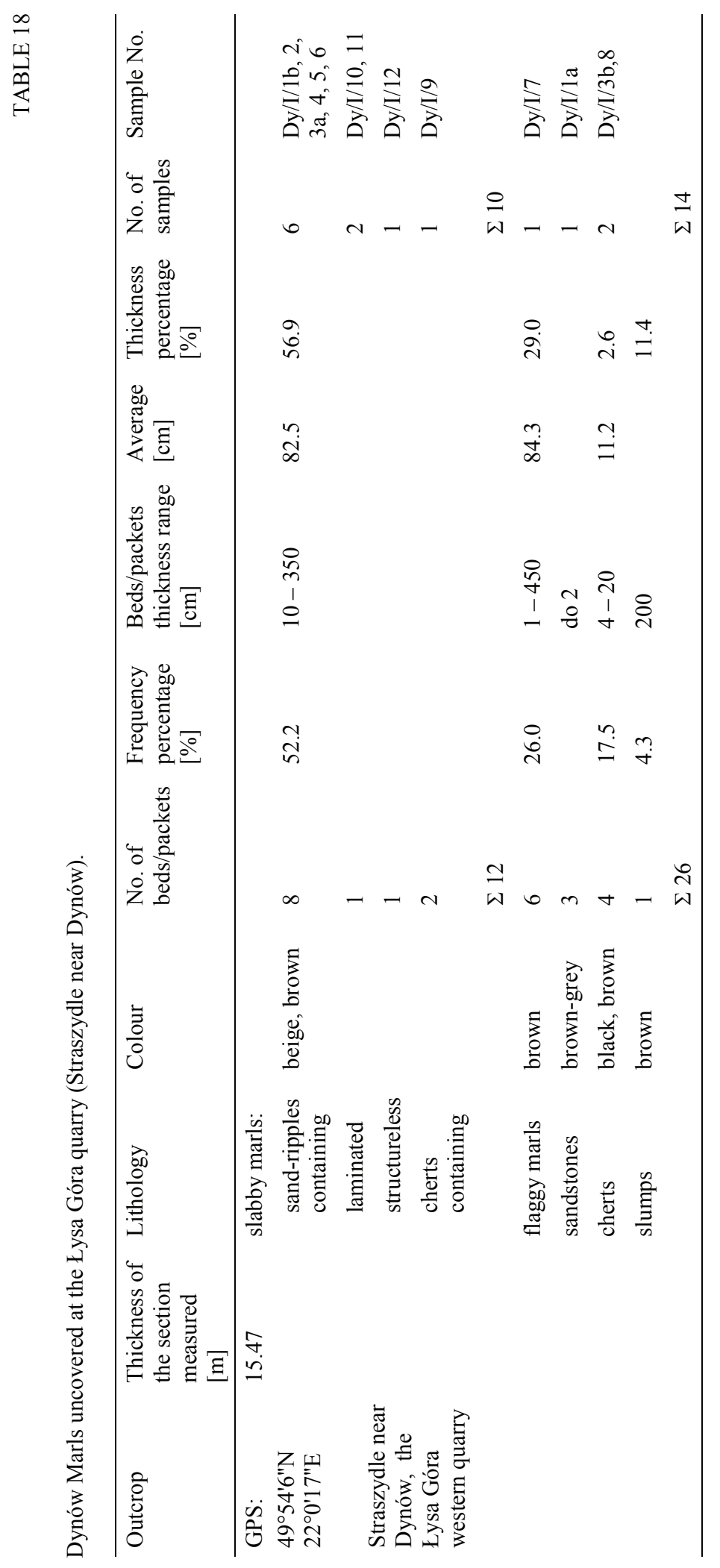



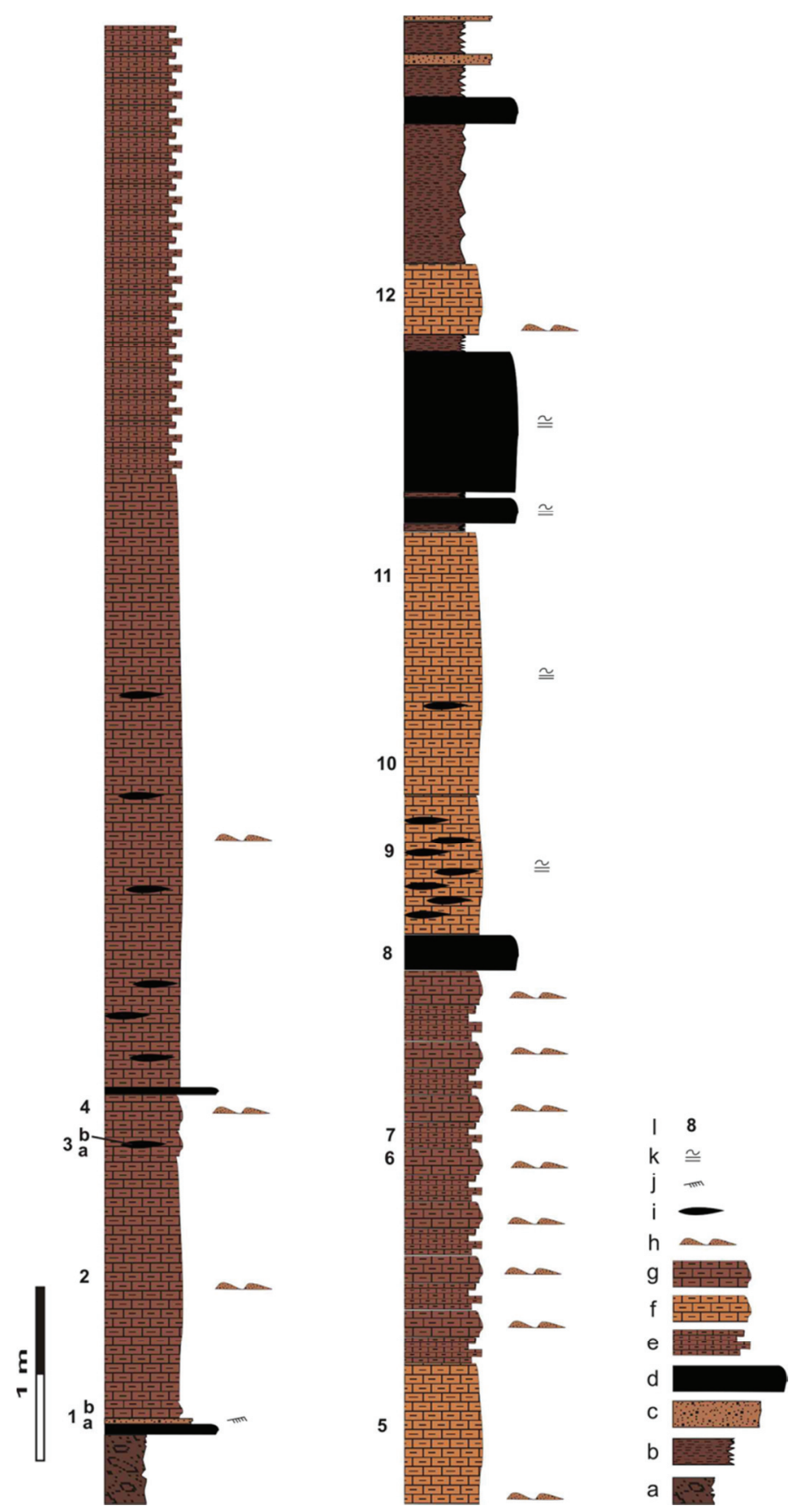

Fig. 18. Lithology of the Dynów Marls uncovered at the Łysa Góra quarry (Straszydle near Dynów, western slope of the Łysa Góra Hill).

Explanations: a - slumps; $\mathrm{b}$ - shales; $\mathrm{c}$ - sandstones; $\mathrm{d}$ - bedded cherts; $\mathrm{e}$ - flaggy marls; $\mathrm{f}-\mathrm{g}$ - slabby marls: $\mathrm{f}$ - beige; $\mathrm{g}$ - brown; $\mathrm{h}$ - sand ripples; $\mathrm{i}$ - chert nodules; $\mathrm{j}$ - cross lamination; $\mathrm{k}$ - parallel-wavy lamination; 1 - samples. 
The slabby parting marls are beige and brown with different tones. They are hard and split. Two structural varieties of these marls have been distinguished: variety beginning with thin sandstone layers and that showing parallel lamination. The variety beginning with thin sandstone layers are common. These sand division initiated marl beds is often discontinuous, lenticular, thin - from several millimeters to $2 \mathrm{~cm}$ thick basal lamina or a single array of isolated (starved) small ripple form-set. In more thick ones crosslamination is visible. These sandstones are fine-grained, brittle, containing mica flakes and carbonized organic matter. Laminated marls are characterized by delicate parallel and wavy variation of colours from brown through beige to yellow. Lamination is locally emphasized by streaks and lenses of cherts.

The flaggy parting marls are brown. They are hard, structureless and display platy fragmentation.

The Dynów Marls are more or less impregnated with silica. This is manifested by streaks and lenses of cherts, more abundant in the bottom of marl beds and disappearing toward the top, as well as chert beds containing relics of marls.

The cherts are black or dark brown. Some varieties show black-creamy-brown fine lamination. They are brittle, irregularly fractured. The fissures are filled with carbonates.

The most common marls in the profile of Dynów marls studied are the slabby parting marls (frequency percentage 52.2\%, thickness percentage 56.9\%) (Table 18). The percentage content of flaggy parting marls is distinctly lower and amounts to $26.0 \%$ and $29.0 \%$ respectively. Cherts occur fairly commonly (frequency percentage $17.5 \%$ ), but due to negligible thickness of beds their thickness percentage is $2.6 \%$.

\section{Summary}

According to the lithologic features of the Dynów Marls in the outcrop studied, (quarry in western slope of the Łysa Góra in the Straszydle Village) slabby parting marls with sandy ripplemarks appear in the lowermost part of the profile, followed upward by flaggy parting marls and, in the top part of the sequence, the laminated slabby marls appear (Fig. 18). Streaks and lenses of cherts that occur in some beds of slabby parting marls disappear toward their top.

\subsection{Genetic types of marls based on their lithology}

\subsubsection{Jurassic marls}

\section{Goleszów Marls (marls from the Lower Cieszyn Shales)}

The Goleszów Marls (Figs. 1, 3) are olistoliths occurring in the Lower Cieszyn Shales that are considered to represent debris-flow type deposits (Cieszkowski et al. 2009). These products of submarine mass movements were formed during the opening of the Silesian basin on the boundary of the Jurassic and Cretaceous epochs.

The Lower Cieszyn Shales (Kimmeridgian - Tithonian) (now Vendryně Formation) are the oldest rocks of the Polish Outer Carpathians (Bieda et al. 1963; Geroch et al. 1967; Nowak 1973a; Ślączka et al. 2006; Olszewska et al. 2008). They are considered to represent pelagic sediments containing a significant proportion of redeposition products of partly 
consolidated shelf deposits (olistoliths) (Peszat 1968; Nowak 1973a; Słomka 1986a, b). This redeposition is documented in marly shales by the presence of mixed microfaunal assemblages from different environments (shelf and benthic foraminifers and radiolaria, diatoms, coccoliths, tintinnids), as well as macrofaunal fragments: e.g. ostracods, echinoderms, bryozoans, molluscs, corals and fish teeth (Bieda et al. 1963; Szydło 1997; Szydło, Jugowiec 1999; Olszewska et al. 2008). It is generally accepted that during the Upper Jurassic /Lower Cretaceous Neo-Cimmerian tectonic activity rifting phenomena in southern part of the North European Platform caused the formation of the proto-Silesian (Severin-Moldavidic) Basin in the area where the Western Outer Carpathians presently are (Golonka et al. 2000; Oszczypko 2004; Ślączka et al. 2006). This basin was gradually filled with black, calcareous muds containing olistoliths of limestones and marls, mainly redeposited from northern shelf of the Tethyan Ocean, and originated from eroded carbonate platform (Ślączka et al. 2006; Słomka et al. 2006). These limestones contain echinodermal plates, algal fragments, siliceous and calcareous sponge spicules, calcitized radiolarians, calcareous foraminiferes and calcareous dinocysts (stomiosphaeras) (Nowak 1973a; Olszewska et al. 2008). Teschenites that occur in the rocks of the Cieszyn Formation are considered to represent extrusion of basic magma related to rift phenomena in the Silesian Basin (Narębski 1990). The low sedimentation rate and the small thickness of sediments from the beginning of sedimentation to Cenomanian indicate that this basin was starved (Słomka et al. 2006).

According to the analysis of lithologic-sedimentological features of the Goleszów Shales Member (Fig. 3; Tables 4, 19), presented in previous chapter, they represent MyG (muddy gravel beds) facies in Ghibaudo's (1992) classification (Table 20). In this author's interpretation, $\mathrm{MyG}$ facies is considered to be the product of redeposition of shelf sediments into deeper parts of the basin in already lithified, rigid form (clasts) and as soft sedimentary material. The olistoliths of limestones and marls occurring in the Goleszów Shales Member represent blocks of intrabasinal origin. The provenance of the matrix embedding these blocks in the MyG facies is related to redeposition of nonlithified, soft sedimentary material. Based on Ghibaudo's (1992) classification it can be assumed that psammitic marls showing diversified parting (slabby and bedded varieties), which appear in Goleszów as olistoliths (Table 4; Fig. 3 - olistoliths: O-1 and O-2, samples: 9 and 10), represent shelf sediments redeposited into deeper parts of sedimentation basin as lithified clasts. The origin of aleuritic marls showing fissile parting (shaly marls), which occurs in the matrix embedding olistoliths (Table 4; Fig. 3 - samples: 1 and 3) can be related to soft sedimentary material transported from the shelf environment. 


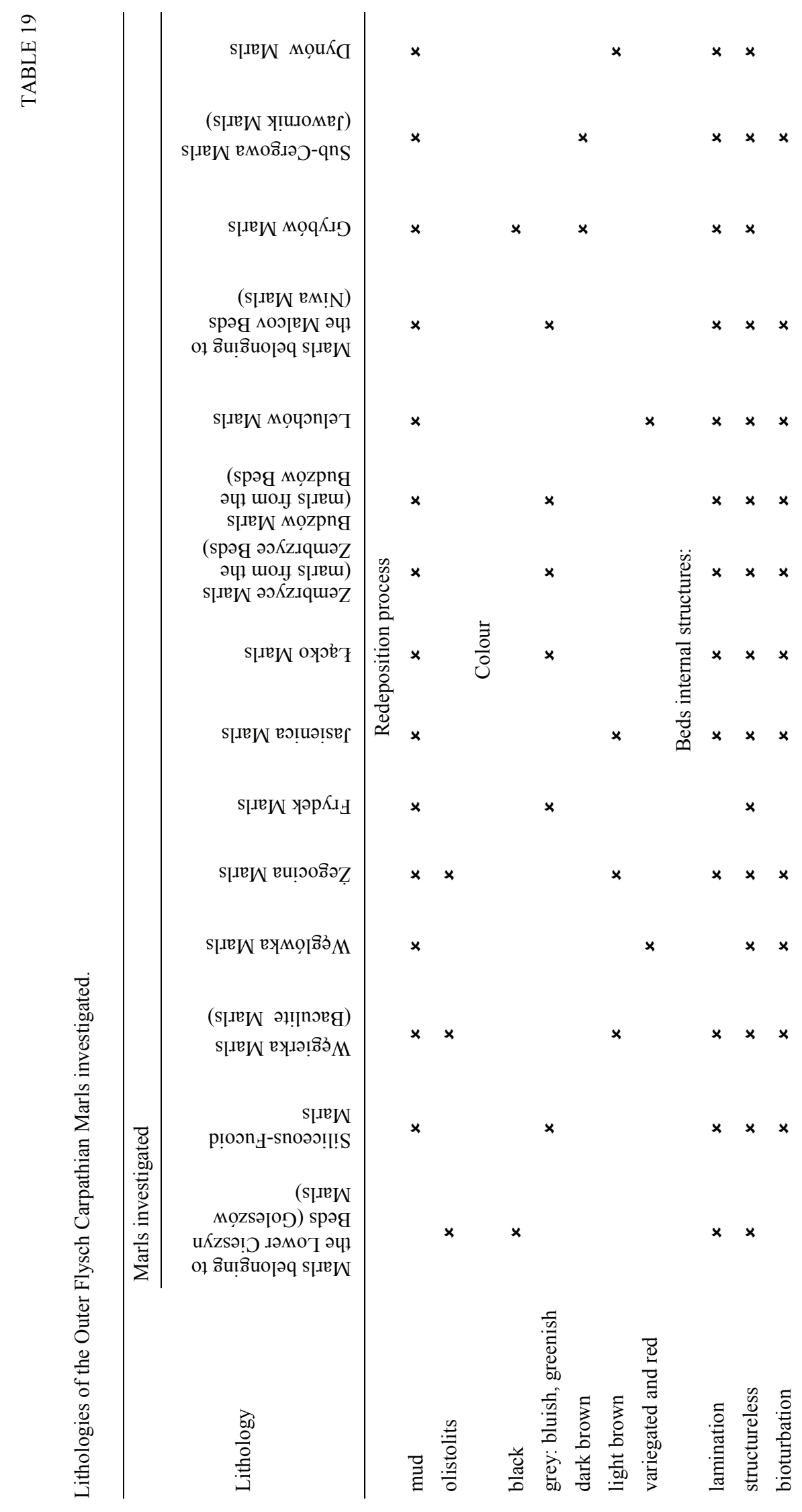




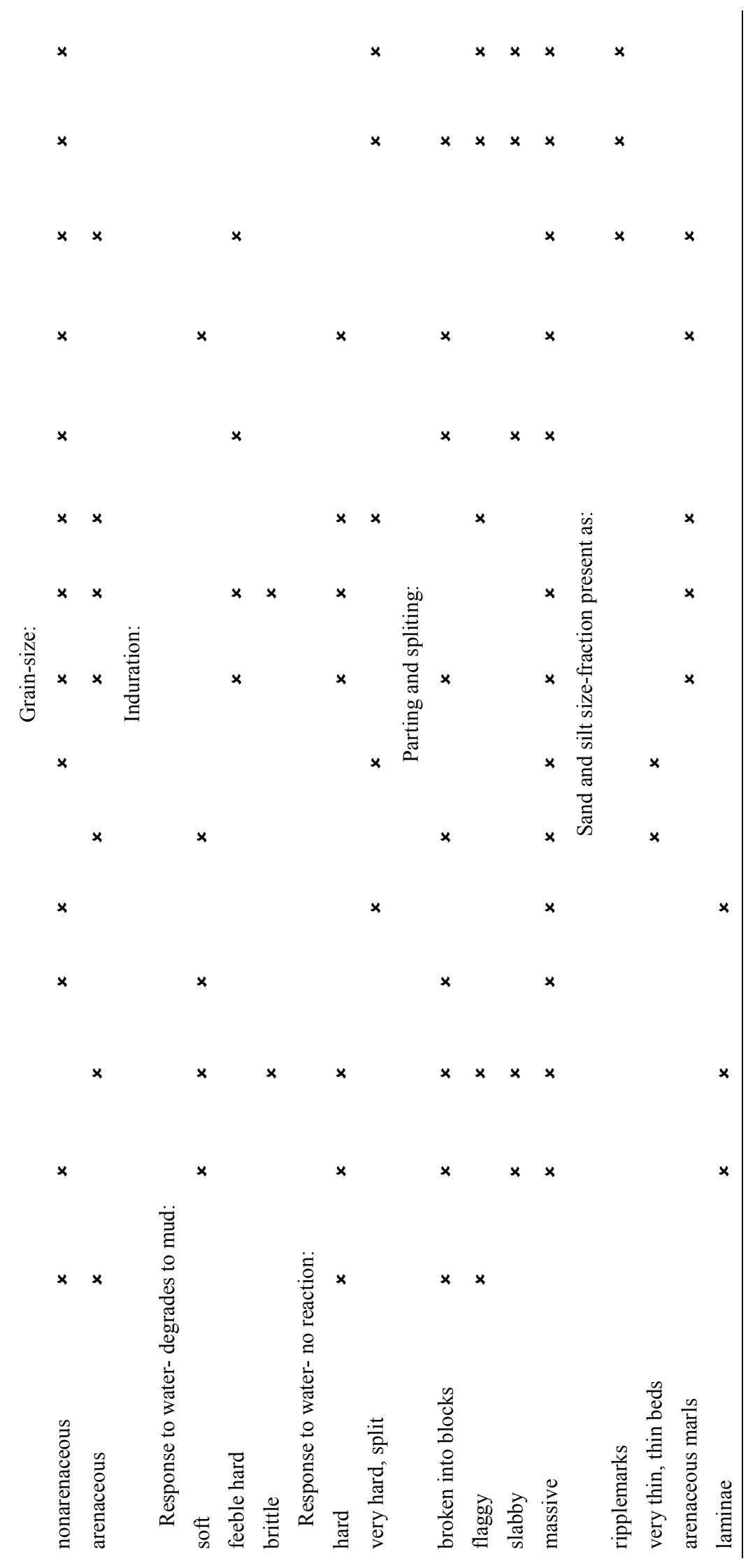




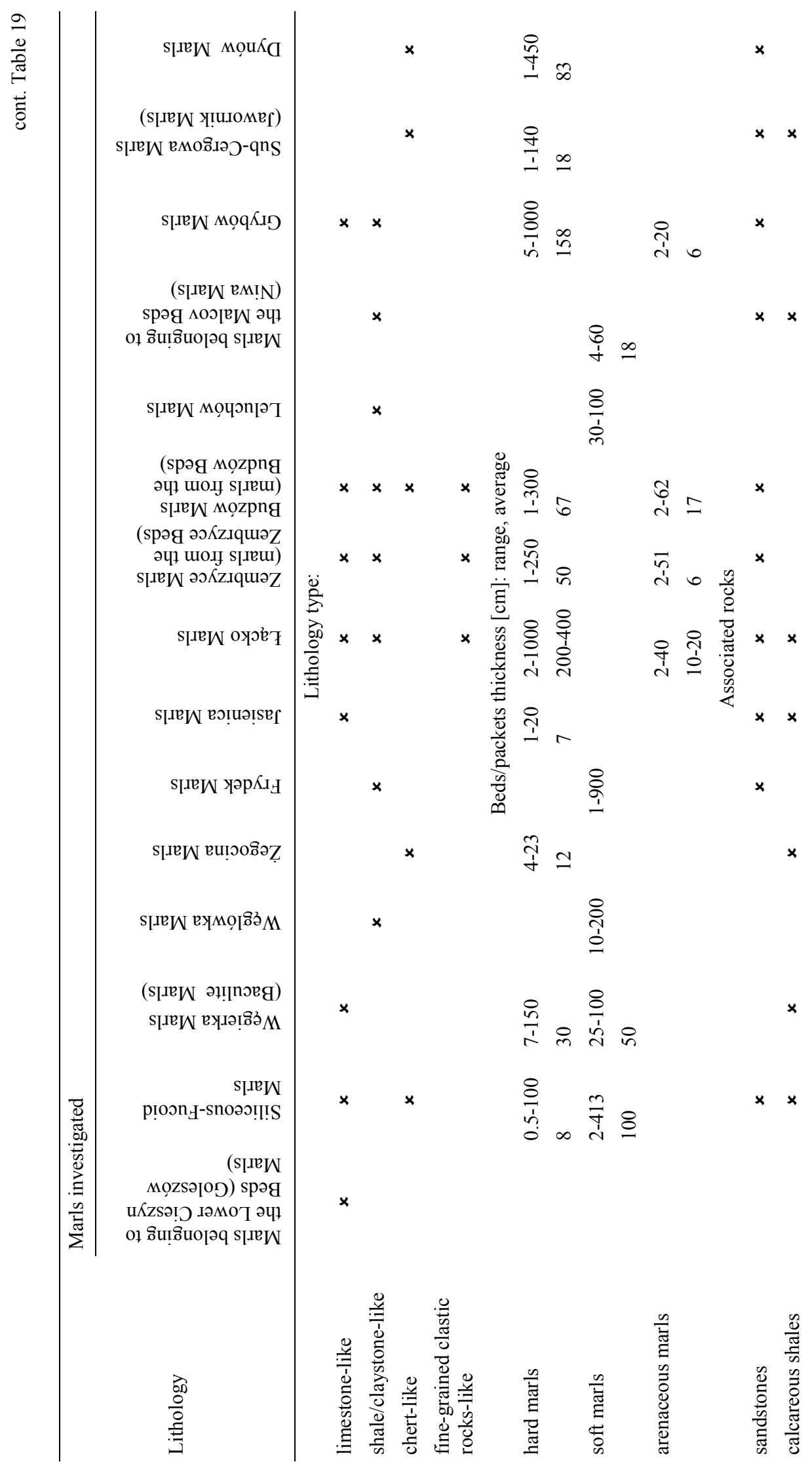




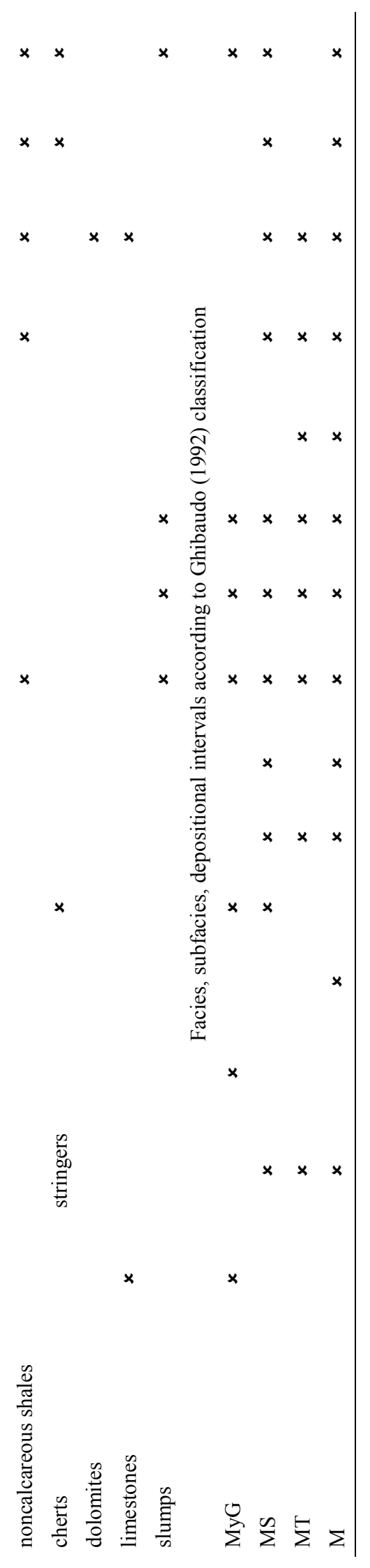




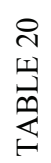

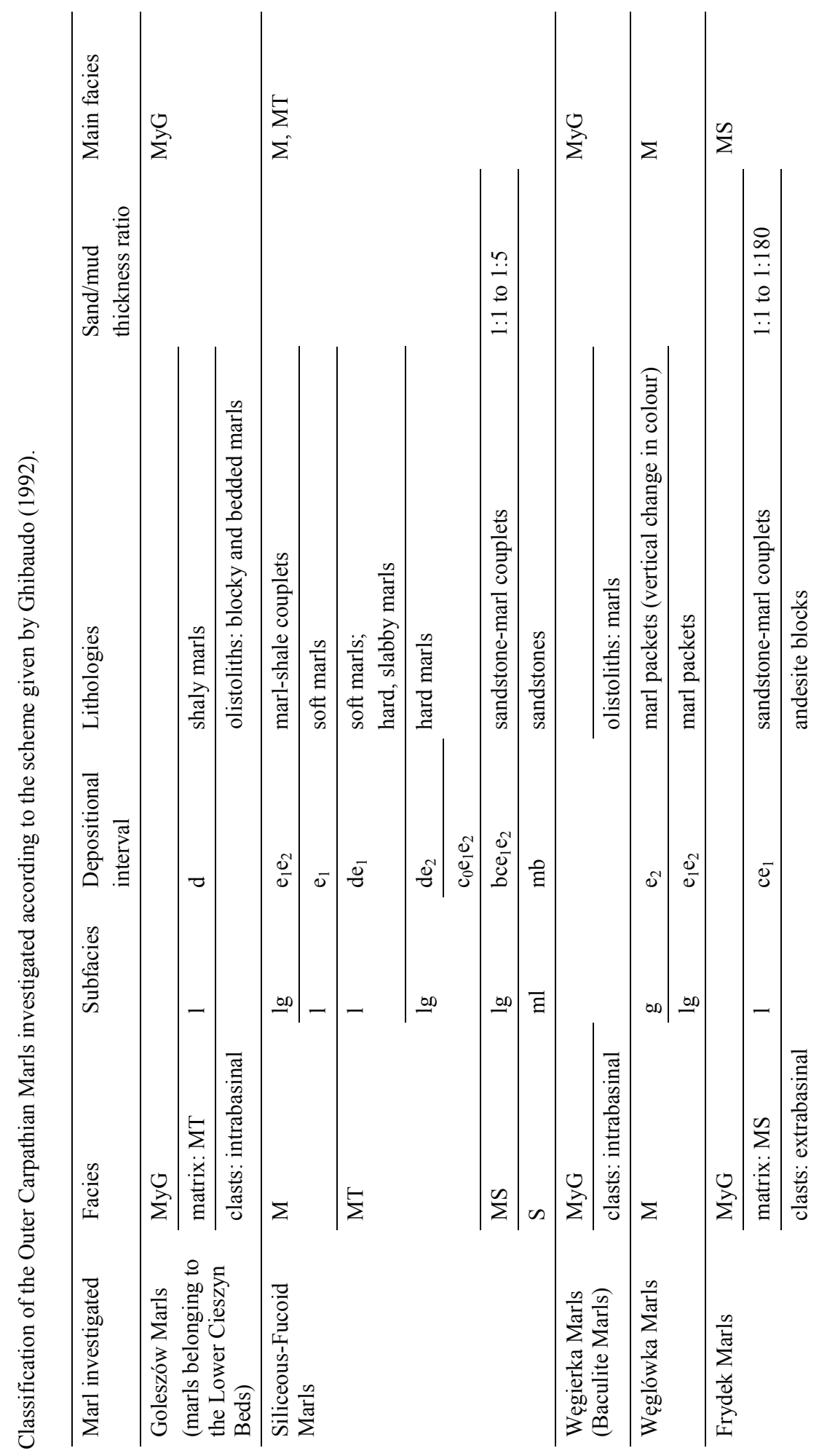




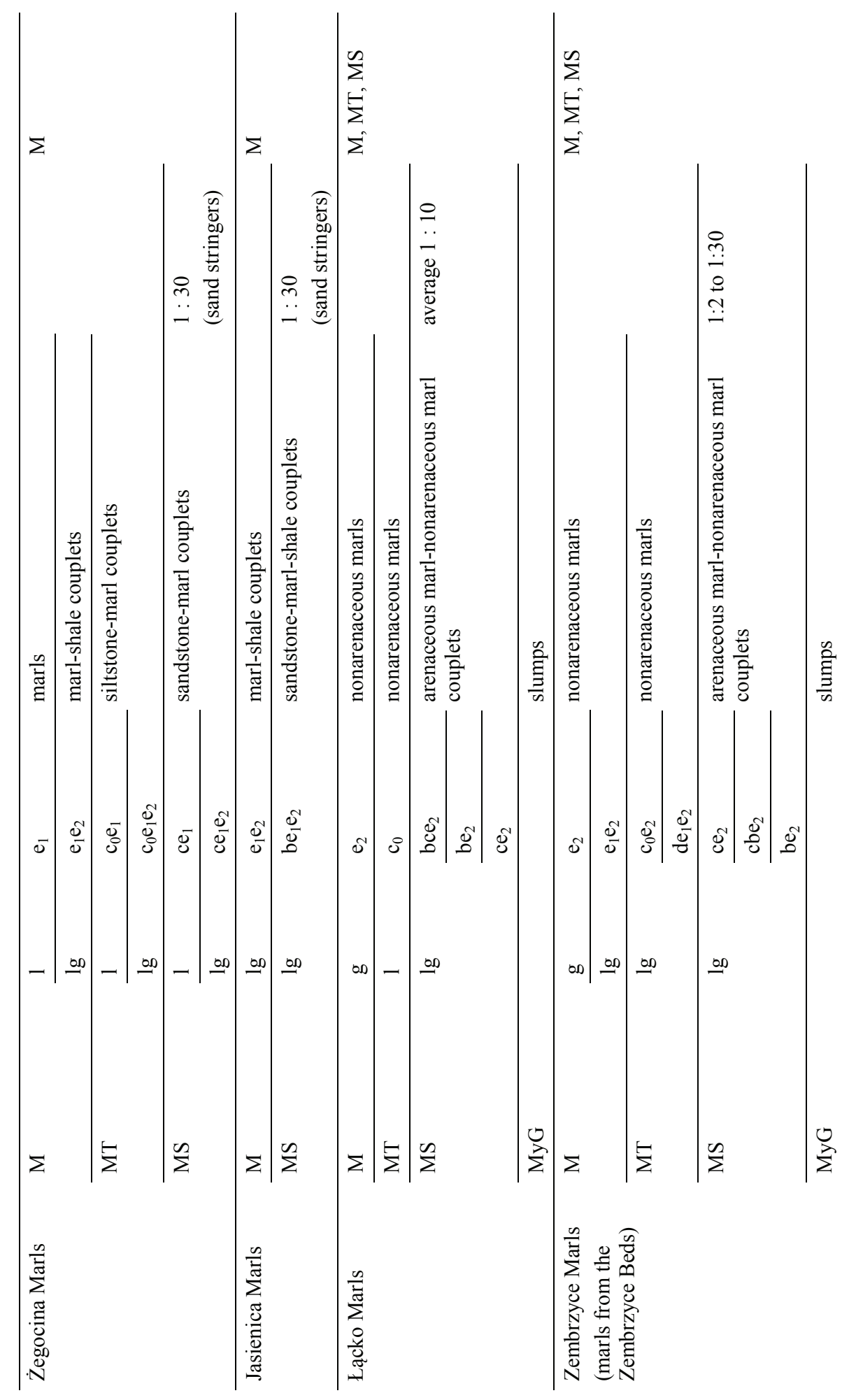




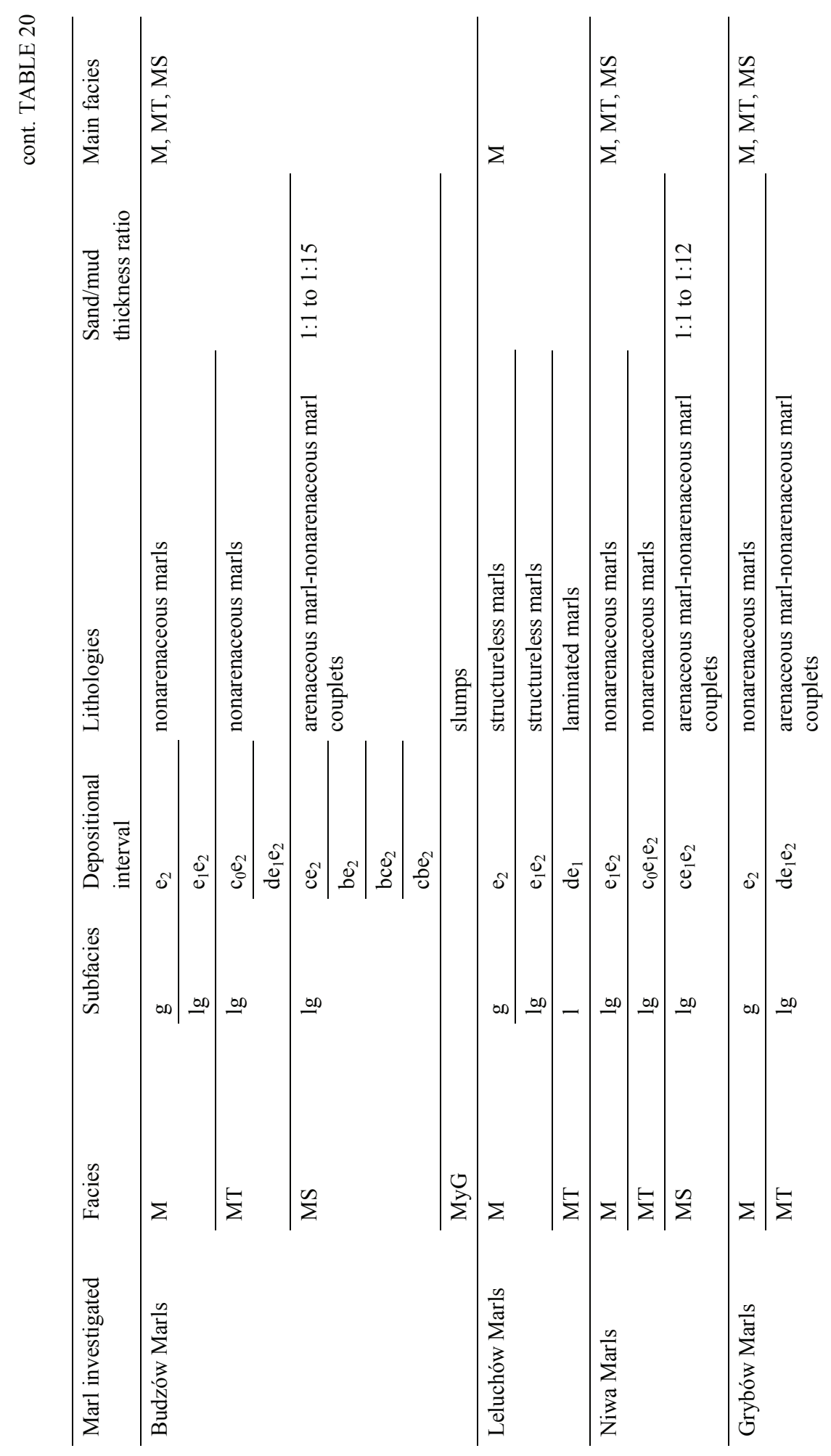




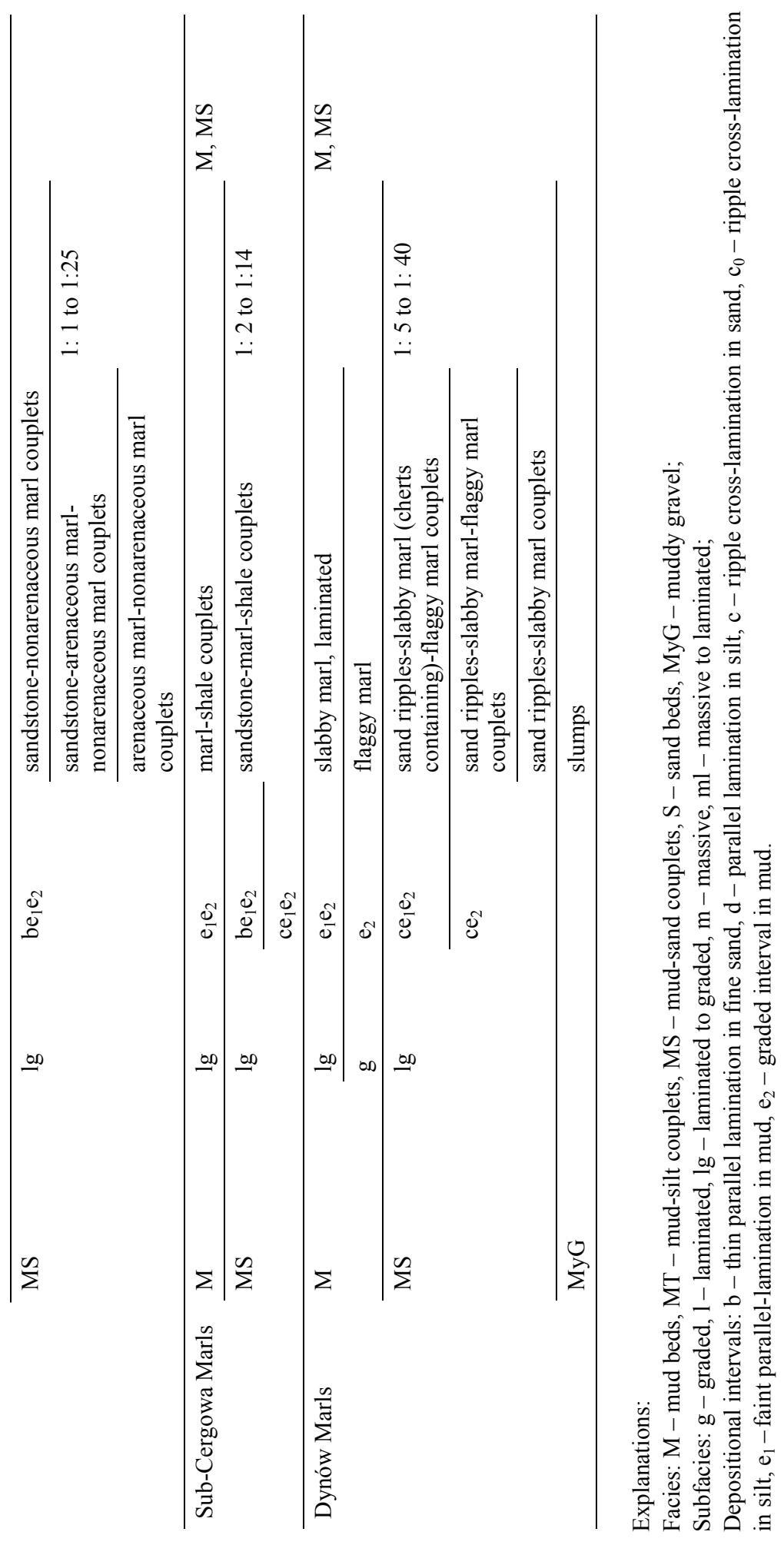




\subsubsection{Upper Cretaceous}

\section{Siliceous-Fucoid Marls}

The Siliceous-Fucoid Marls (Fig. 4) are calcareous turbidites (Kotlarczyk 1978, 1979, 1988; Leszczyński et al. 1995; Leszczyński 2003). Their source area was the northern margin of the Outer Carpathians basin. They are considered to represent calcareous oozes formed on the slope of a wide shelf (Książkiewicz 1962; Koszarski 1985a) and resedimented into deeper parts of the Skole basin together with calcareous muds (Bromowicz 1974), and in Kotlarczyk's $(1978,1988)$ opinion, they originated from the erosion of limestones in the cliff. It is thought that the increase of intensity of turbidity currents proceeded in two stages. The Siliceous Marls (Turonian-Santonian) indicate tectonic activity leading to the separation of the Skole basin from remaining part of Outer Carpathian basin on the boundary of the Cenomanian/Turonian, whilst the Fucoid Marls indicate its reconstruction on the boundary of the Santonian/Campanian (Kotlarczyk 1979, 1988; Malata, Poprawa 2006).

The Siliceous Marls initiate the first of three evolutionary cycles of the Ropianka Formation distinguished by Kotlarczyk $(1979,1988)$, corresponding to the introduction of the flysch formation into the Skole basin. In this author's opinion, an analogical cycle in the Silesian Basin formed the Cieszyn Limestones and Shales. The Fucoid Marls initiate the second cycle of complete development of the flysch facies in the whole Skole basin. Szczepanowice calcareous flysch (corresponding to the Hołownia Siliceous Marls and at least partly to the Kropiwnik Fucoid Marls) was deposited in the central part of the Skole Basin (Koszarski 1985a). In Koszarski's (1985a) opinion, such thin-bedded calcareous flysch also occurs (however in smaller scale) among Turonian sediments of the SubSilesian Unit (Żegocina Marls) and of the Silesian Unit (siliceous Kaczyna Marls in the bottom of the Godula Beds). In this author's opinion, similar sedimentological features are also characteristic of slightly older "siliceous marls", which occur among the Cenomanian deposits of the above units (uppermost part of the Lgota and Gaize Beds and the lower part of the Green Radiolaria Shales). In Ślączka and Kamiński's (1998a) opinion, these siliceous marls can be a record of a periodical rise to the surface of the CCD level, which was marked in Early Campanian in the Atlantic Ocean and western part of the Tethys Ocean.

Based on present studies carried out in the outcrop of the Siliceous-Fucoid Marls (Table 5) it can be concluded that the sandstone-mudstone couplets that occur in the lowermost part of this profile can be assigned in Ghibaudo's (1992) classification to the M facies (muddy beds), represented by subfacies $\operatorname{lgM}$ (laminated to graded mud beds) of the $\mathrm{e}_{1} \mathrm{e}_{2} \mathrm{M}$ type (faintly parallel-laminated mud, graded to ungraded mud). The sandstone-marl-shale beds correspond to the MS facies (mud-sand couplets), represented by subfacies IMS (laminated mud-sand couplets), and these are the beds of bce $\mathrm{e}_{2} \mathrm{MS}$ type (parallel and crosslamination in fine sand, faint parallel-lamination in mud, graded interval in mud).

According to Ghibaudo's (1992) classification, the soft marl beds, which appear in the middle part of the profile, correspond to the $\mathrm{M}$ facies, $1 \mathrm{M}$ subfacies (laminated mud beds) of the $\mathrm{e}_{1} \mathrm{M}$ type (faintly parallel-laminated mud) and to the MT facies (mud-silt couplets), IMT subfacies (laminated mud-silt couplets) of the $d_{1}$ MT type (alternating planar regular to irregular silt and mud laminae, faint parallel lamination in mud). The beds of hard platy 
marls and hard marls exhibit the properties of sediments of the facies MT, subfacies lgMT and the $\mathrm{de}_{1} \mathrm{MT}$ and $\mathrm{de}_{2} \mathrm{MT}$ type respectively (alternating planar regular to irregular silt and mud laminae, graded to ungraded mud) and $c_{0} c_{1} e_{2}$ MT type (silt ripples cross-lamination, faint parallel-lamination in mud, graded to ungraded mud). The sandstone bed represents the $\mathrm{S}$ facies, and the subfacies $\mathrm{mlS}$ (massive to laminated sand) of the mbS type (massive to parallel lamination in fine sand) (Fig. 4).

In Ghibaudo's (1992) classification, in the upper part, similar to in the middle part of the profile, the soft marls represent the $M$ facies, $1 M$ subfacies of the $e_{1} M$ type, whereas hard marls represent the MT facies and the lgMT subfacies of the $d_{2} \mathrm{MT}$ and $\mathrm{c}_{0} \mathrm{e}_{1} \mathrm{e}_{2} \mathrm{MT}$ type. On the other side, sandstones represent $\mathrm{S}$ facies, $1 \mathrm{~S}$ subfacies of the mbS type.

According to the present author's studies, lithologic-sedimentological features of beds of the Siliceous-Fucoid Marls (Fig. 4; Tables 5, 19) correspond to the three finest grained facies in the Ghibaudo's (1992) classification. The most common are beds showing characteristic features of the M (mud beds) and MT (mud-silt couplets) facies, while less abundant are those corresponding to the MS (mud-sand couplets) (Table 20). The M and MT facies are related to the deposition from low-concentration turbidity currents composed of silt and mud, both of siliciclastic and composed of calcareous/siliceous bioclastic material as suspended load. The Siliceous-Fucoid Marl beds document the deposition from turbidity currents abounding in bioclasts. Such deposits are distinguished by Stow (1984) as biogenic turbidites. Parallel lamination, which is very common in these marls (depositional intervals $\mathrm{d}$ and $\mathrm{e}_{1}$ ) (Table 20), documents a traction and fall-out deposition with depositional sorting of silt- and clay-sized grains that interrupts episodic settling from suspension (depositional interval $\mathrm{e}_{2}$ ), and the appearance of cross-lamination (depositional interval $\mathrm{c}_{0}$ ) indicates diversified contribution of reworking of sediment by bottom currents. The deposition from traction carpets at the base of low-concentration turbidity currents and reworking of sediments by bottom currents is also documented by depositional intervals $b$ (parallel lamination) and c (cross lamination) respectively. They occur in the sandy division of sandstone-marl beds, representing the MS facies in Ghibaudo's (1992) classification. In this author's opinion, the MS facies can be interpreted as incomplete, base-cut-out Boumatype sequence.

The distinguished facies in this fragment of profile of the Siliceous-Fucoid Marls have recorded the deposition of fine-grained material. According to the analysis of bed's internal structures (Table 20) and Ghibaudo's (1992, Table 5) data for the deposits of lowconcentration turbidity currents, they represent the products of several processes: deposition from traction with depositional sorting of grains, settling from suspension and the reworking of sediments by bottom currents.

\section{Węgierka (Baculite) Marls}

The Węgierka (Baculte) Marls (Figs. 1, 5) are olistoliths, olistostromes and single beds occurring within siliciclastic basinal deposits of the Leszczyny Member (Late Maastrichtian - Early Palaeocene) of the Ropianka Formation. The Węgierka Marls contain micro- and macro-fauna (benthic calcareous foraminifers, globotruncanes, cephalopods and molluscs) characteristic of a shallow shelf environment and their Upper Cretaceous (Maastrichtian) age (Geroch et al. 1979). The shallow-water environment of sedimentation of the Węgierka 
Marls is also indicated by their sedimentary structures (Geroch et al. 1979) and Maastrichtian age by nannoplankton data (Jugowicz-Nazarkiewicz 2007). The Węgierka Marls are considered to represent products of submarine mass movements, transporting sediments from shallow marine, shelf zone developed in the northeastern margin of the Skole Basin, which was connected to the epicontinental sea on the East-European Platform (e.g. Burzewski 1966; Bromowicz 1974; Geroch et al. 1979; Kotlarczyk 1978, 1979, 1988). In these authors' opinions, from the Maastrichtian to Palaeocene, both sediments lithified to various degree yet in shelf environment and loose calcareous muds were redeposited into deeper parts of the basin. This is evident by the presence of olistoliths, of agglutinated limemud clasts in olistostromes and of sandstone beds in bedded complexes of the Baculite Marls (Bromowicz 1974; Geroch et al. 1979; Kotlarczyk 1978, 1979. 1988). In Gucik's (1988) opinion, olistoliths of the Baculite Marls have slipped into deeper parts of flysch basin in the Palaeocene. This is indicated by Palaeocene microfauna found in the thickbedded Inoceramian Sandstones and the Tuligłów Black Shales that occur, according to this author, at the contact with olistoliths in Węgierka.

Submarine slumps slid from the north down the slope of the basin across its axis, whilst the directions of transport in the siliciclastic flysch of the Leszczyny Member indicate the transport of noncalcareous material along its axis from the NW and W (Bromowicz 1974, 1986; Kotlarczyk 1978).

The olistoliths that occur in Węgierka were deposited in the shallower marginal part of the Skole basin, whereas in Babice the olistoliths are more distant from its shore and in deeper zones. It is thought that these mass movements were caused by the change of the tectonic regime to compressional, which resulted in moderate tectonic uplift of the Skole basin and of the source areas, taking place from the Turonian to the Maastrichtian (Malata, Poprawa 2006). The compression of the Outer Carpathian Basin is connected to the folding and overthrusting in the Outer Carpathians (Książkiewicz 1972). In Kotlarczyk’s (1978) opinion, the appearance of the Baculite Marls initiated the third, last evolution cycle of the Ropianka Formation, indicating a decrease of denudation activity and a disappearance of flysch sedimentation in the Skole Basin.

According to Ghibaudo's (1992) classification, the examined olistoliths of the Baculite Marls (Fig. 5; Tables 6, 19) can be considered to be a component of the MyG facies and distinguishes them as rocky blocks of intrabasinal origin redeposited from the shelf into deeper parts of the sedimentation basin as already rigid sediment (Table 20). Lenticular bedding and parallel lamination, common in the Baculite Marls, arise from changes in grain size (fine sand-sized grains) and in composition between laminae. They indicate a variation of fluctuation in sediment supply and in flow strength reworking bottom shelf sediments, and deposition from slow-moving sediment clouds (Reineck, Singh 1980).

\section{Węglówka Marls}

The Weglówka Marls (Figs. 1,6) are thought to represent pelagic sediments deposited above the CCD level, representing in the Sub-Silesian Unit, locally in Fore-Magura Scale, in the eastern part of the Silesian Unit and in the inner part of the Skole Unit a facies equivalent of deep-water variegated shales (Książkiewicz 1962; Bieda et al. 1963). They appear, similar to the Siliceous-Fucoid and the Baculite Marls, in the second stage of 
tectonic evolution of the Outer Carpathians i.e. during the Late Cretaceous creation of several sedimentary sub-basins. As already mentioned, tectonic differentiation of the morphology of the seafloor of the Outer Carpathian Basin was caused by promoting orogenesy of the Inner Carpathians and the Alps, that resulted in the change of tectonic regime within the basement of the Outer Carpathian Basin from extensional into compressional (Książkiewicz 1972; Malata, Poprawa 2006). On the boundary of the Cenomanian/Turonian, the initiation of uplift of the Silesian Cordillera and of submarine elevation (the Sub-Silesian and Fore-Magura Ridges) separated individual sedimentation basins. Marly facies developed on submarine elevations and on shelves of cordillera. In the Skole and Silesian Basins, separated by the Sub-Silesian (Węglówka) Ridge, very thick complexes consisting predominantly of sandy, turbidite sediments (Inoceramian Beds of the Skole series, up to more than $1500 \mathrm{~m}$ thick) and fluxoturbidites (Godula and Istebna Beds in the Silesian series, more than $3000 \mathrm{~m}$ and $1700 \mathrm{~m}$ thick respectively) were deposited. The Węglówka Marls (predominantly Campanian, according to Bieda et al. 1963) were particularly developed on the Sub-Silesian (Węglówka) Ridge. In some authors' opinions, their slow sedimentation ( 5 - 30 meters per Ma) lasted about $45 \mathrm{Ma}$. The height of the Sub-Silesian Ridge above the seafloor of the Silesian Basin is considered have been about $700 \mathrm{~m}$ and the height of the water column above this elevation at the beginning of Campanian to have been at least $3000 \mathrm{~m}$ (Słomka et al. 2006).

The conditions in the Carpathian basins before, during and after the sedimentation of the Weglówka Marls are documented by the rocks underlying these marls, isochronous facies equivalents and the series overlaying them. Sedimentation of variegated marls (Węglówka Marls) on the Sub-Silesian Ridge started on the boundary of the Cenomanian and Turonian (locally Lower Senonian) with the deposition of the Variegated Shales grading continuously into marls. The Variegated Shales appear after the Green Radiolariabearing Shales, formed in later Cenomanian and the earliest Turonian in the whole Outer Carpathians, during a dropout of activity of source areas and when the Outer Carpathian Basin had reached maximal range and depth. In the Outer Carpathian Basin from the Cenomanian to Campanian (Maastrichtian?) (Słomka et al. 2006) was the compressional stage, and its intensive filling by flysch deposits was accompanied by sedimentation of marls on submarine ridges and shelves. In these authors' opinion, a high rate of deposition of the Godula and Istebna Beds (100 to $400 \mathrm{~m}$ per Ma and about $100 \mathrm{~m}$ per Ma respectively) is evidence of an uplift of source areas and their intense erosion. The Variegated Shales, which are considered to represent a deep-water equivalent of the Weglówka Marls deposited above the CCD level, appear in the Skole Basin as intercalations in the Inoceramian Beds (Tereszów and Kanasin Variegated Shales) and there represent, in Kotlarczyk's (1978) opinion, the correlation horizons. In the Silesian basin, the Variegated Shales replace eastwards the sandy-shaly flysch series (Słomka et al. 2006). It indicates the oscillations of the depth of the Skole Basin and an eastward increase in depth of the Silesian Basin during sedimentation of the Węglówka Marls. The Sub-Silesian submarine elevation (Sub-Silesian Ridge), separating these sub-basins, was - in the opinion of Słomka et al. (2006) - morphologically diversified, showing tendency to incline to the south and west. Consequently, the uplifting movements emerged more often in its western part. It is considered that the variegated Weglówka Marls were locally replaced by siliceous marls (Jasienica Marls and Żegocina Marls) and in shallower zones by gray marls of 
Frydek type. At the foot of the ridge small submarine fans were formed - the Rybie Beds, about $300 \mathrm{~m}$ thick. Transport directions indicate that the Sub-Silesian Ridge could partly be the source of material for the Istebna Beds, deposited from the Campanian in the Silesian Basin (Słomka et al. 2006). Worth noting is that Narębski (1960), based on detailed geochemical study, links the phosphate nodules formation in the Upper Cretaceous Węglówka Marls to exhalations from volcanic phenomena associated with the Laramian tectonic movements that resulted in the reconstitution of the Outer Carpathian Basin. This author points out that these volcanic phenomena are documented by intercalations of pyroclastic rocks in isochronous facies equivalents of the Węglówka Marls (e.g. Bachowice and Bugaj horizons within variegated shales). The Węglówka Marls, which grade into the Variegated Shales or the Hieroglyphic Beds, are overlain by Upper Eocene Green Shales and subsequently the Globigerina Marls appear, representing the upper part of Upper Eocene (Bieda et al. 1963). This appearance of the Green Shales and the Globigerina Marls in the Carpathian profiles is interpreted as a record of decreasing activity of source areas (Poprawa et al. 2006). Worth emphasizing also are the reports of some authors on the volcanic material, which occurs in the Palaeogene Variegated Shales of the Sub-Silesian and Skole Units. Wieser (1954) has found dacitic tuffs in the Palaeogene Variegated Shales of the Sub-Silesian Unit in Bachowice, and in the Skole Unit there are intercalations of pyroclastic rocks with glass fragments of rhyodacitic and dacite-andesite composition. The main components of the Variegated Shales of the Skole Unit (Lower Eocene) are smectite and zeolites. Its origin is related to the transformation of volcanic glass (Wieser 1994). As reported by Leszczyński and Uhman (1991), the variegated shales are lithologically very diversified. Based on grain-size and bed's internal structures, these authors have distinguished six facies in these shales, representing turbidites, contourites, cohesive flow and slump deposits and pelagic/hemipelagic sediments. It should be emphasized that the intercalations of pyroclastic rocks appear only in the last type of deposits distinguished (Leszczyński, Uhman 1991, Fig. 3A).

Bathymetric conditions for the Węglówka Marls exposed in stratotype area (Węglówka Tectonic Half-Window, outcrops in Czarny Potok Stream in Węglówka), based on microfaunal studies are presented by Gasiński et al. (1999). In their opinion, they were deposited from Campanian to Maastrichtian, under conditions corresponding to outer shelf or upper and middle part of the slope, during the connection of the Tethian Ocean with boreal basin, which is documented by foraminiferal assemblage and calcareous nannoplankton. It should be emphasized that similar deposits appear locally in the same time in marginal zones of the Atlantic Ocean (e.g. the North Sea Chalk - Brasher, Vagle 1996).

According to the present lithologic studies performed in the stratotype area (Fig. 7), in the profiled outcrop of the Węglówka Marls, about $30 \mathrm{~m}$ long, located similar to exposures examined by Gasiński et al. (1999, Fig. 2), they are megascopically monotonous, homogeneous, fine-grained (clay- and silt-sized), structureless and bioturbated. Thick and medium beds are distinguishing due to variable tints of red and green colours (Fig. 6, Tables 7, 19).

The grain-size allows the Weglówka Marls to be assigned to the facies M (muddy beds) in Ghibaudo's (1992) classification (Table 20). As already mentioned, the varicoloured marl beds are homogeneous but in some of them a change in colour in their top part is 
visible (Fig. 6). In Ghibaudo's (1992) opinion, a subtle vertical change in colour often indicates subtle upward decrease in the maximum grain size and in the silt/clay volumetric ratio. For the bed of these marls showing dark red colour in the lower and pink in the upper part (samples W1/1/6 and Wl/1/5, Fig. 6) the estimative proportions of silt and clay fractions varies from 0.8 to 0.6 . Therefore, it is possible to assign the beds of the Węglówka Marls, changing colour in the top, to the subfacies gM (graded beds) of the $\mathrm{e}_{2} \mathrm{M}$ type (graded to ungraded beds). Numerous bioturbations visible in the marls studied render difficult the deciphering of beds internal structures in these marls. However, in optical microscope images parallel orientation of elongated components is locally visible. Moreover, there also appear not distinct, discontinuous, often deformed streaks, usually composed of a few, loose distributed silt-, sporadically fine sand-sized grains of biogenic and terrigeneous material. These data allow to assign the beds of Weglówka Marls to the lgM subfacies (laminated to graded beds) and to distinguish the depositional intervals $\mathrm{e}_{1} \mathrm{e}_{2}$ (faintly parallel-laminated mud, graded to ungraded mud) (Table 20). This indicates the influence of overlapping three sedimentary processes in the origin of this fragment of the Węglówka Marls sequence: settling of grains through the water column $\left(\mathrm{e}_{2}\right)$, episodic deposition from traction $\left(\mathrm{e}_{1}\right)$ and reworking by bottom currents (streaks of coarser grains). Such features as: record of currents activity and lack of interbedding of biogenic-rich and biogenic-poor intervals that are, in general, characteristic of pelagic and hemipelagic sediments (vide Stow 1985) indicate, that the studied fragment of profile of the Weglówka Marls represents contourite deposits, and more precisely - muddy contourites. This conclusion has been drown from the features of marl packages described above, that correspond to muddy contourites according to Stow's (1985, Fig. 3A, Table 1) criteria.

The diversification of colours of the Węglówka Marls can be related to the conditions of sedimentation and early diagenesis. It is generally accepted that the change of red colours, characteristic of sediments deposited at the oceanic bottom under oxidizing conditions, was caused by increased supply of organic matter (Gardner et al. 1978). This model can also be applied to the Węglówka Marls. Micropaleontological investigations have shown that green marls, apart from agglutinated foraminifers, also contain numerous calcareous planctonic and benthic ones. The red marls contain mainly agglutinated foraminifers and the admixture of calcareous forms is represented mainly by benthic spaces (Koszarski, Ślączka 1973). The relation of change of red colour into green with organic matter is documented in the marls studied by the occurrence of green spots around burrows in red marls.

\section{Frydek Marls}

The Frydek Marls (exotic material-bearing gray marls) (Figs. 1, 8) are considered to represent a lateral, more shallow-water equivalent of the Węglówka Marls (SkoczylasCiszewska 1960). The Frydek Marl facies (exotic material-bearing gray marls) in fact substitutes the Węglówka Marl facies (variegated marls) westwards in only some places in the Polish Western Carpathians, but completely in the Cieszyn Silesia and Moravia area. It is accepted that the Sub-Silesian Submarine Ridge showed a tendency to incline to east and south, and consequently the uplifting movements more often emerged the fragments of its western part (Słomka et al. 2006). The sedimentation rate of the Frydek Marls from the Sub-Silesian Unit is estimated to have been about $7 \mathrm{~m} / \mathrm{Ma}$ (Słomka et al. 2006). The marls 
of Frydek type, exposed in the Żegocina Tectonic Zone in the Pluskawka Stream are Campanian-Maastrichtian in age (Skoczylas-Ciszewska 1960; Gasiński et al. 1999).

Andesites occurring in the Frydek Marls are considered by Skoczylas-Ciszewska (1956, 1960) to represent fragments of lava flows and tuffaceous deposits related to the Upper Cretaceous-Palaeocene pre-orogenic volcanism. Koszarski (1985b) suggested their similarity to andesite blocks occurring in the Lower Cretaceous Spas Shales in marginal parts of the Skole Unit. Since andesites are accompanied by olistoliths of Tithonian limestones, he considers these two rock types to be exotics that slid from the northern margin of the Skole basin. In this author's opinion, they represent relics of Jurassic orogeny with Kimmeridgian calc-alkaline volcanism, localized in northern source area for the Outer Carpathian Basins. The Middle Jurassic age of the andesite blocks from the Żegocina Tectonic Window is suggested by Ślączka (1998) and Ślączka et al. (1999) on the basis of isotopic data.

According to the studies of a fragment of profile of the Frydek Marls (Fig. 8; Tables 8, 19) their lithologic-sedimentological features correspond to the MS facies (mud-sand couplets), IMS subfacies (laminated mud-sand couplets) and depositional interval ceMS (cross-lamination in fine sand, faintly laminated mud) in Ghibaudo's classification (1992) (Table 20). In this author's opinion, the MS facies can be interpreted as an incomplete, base-cut-out Bouma sequence. Reworking of the sediments by bottom currents is documented by c depositional interval (cross-lamination) occurring in sandy division of sandy-marly composite beds, which appear in the outcrops studied. Depositional interval $\mathrm{e}_{2}$, occurring in the marly division of composite beds, documents the deposition from traction, interrupting the episodic settling of grains suspended in the water column. The MS facies documents the deposition of fine-grained material from low-density turbidity currents, which have earlier deposited coarser material.

According to the analysis of the bed's internal structures of the Frydek Marls and Ghibaudo's (1992, Table 5) data for the deposits of low-concentration turbidity currents, the sandy-marly composite beds document the following depositional acts: sedimentation from traction and reworking of sediments by bottom currents, interrupting settling of grains from a suspension. The occurrence of the above mentioned exotics within the Frydek Marls sequence, noted earlier in exposures in the Pluskawka stream banks by SkoczylasCiszewska (1960), indicates that the described fragment of profile only represents the matrix of the MyG (muddy gravel beds) facies in Ghibaudo's classification (Table 20). These exotics, represented by magmatic (granites), metamorphic (gneisses), sedimentary (Tithonian limestones) and volcanic (andesites) rocks may be extrabasinal clasts of basement provenance. It is also possible that the exotics of effusive rocks (andesites) may represent blocks of synsedimentary origin and are of intrabasinal provenance.

In Ghibaudo's (1992) opinion, the matrix of the MyG facies seems to be formed due to redeposition of soft sedimentary material. It should be remembered that the opinion on more shallow-water origin of the Frydek Marls when compared to the Węglówka Marls can be slightly confirmed by the present author's studies of grain-size distribution of representative samples of these rocks ( $\mathrm{Fr} / \mathrm{P} / 4$, Fig. 8; WI-II/4 and W/II/5, Fig. 7). The Frydek Marl contains more sand-sized grains (about $3 \%$ and $0.3 \%$ respectively) and few more noncarbonate silt-sized grains ( $22 \%$ and $17 \%$ respectively). Moreover, the sandy fraction is coarser grained (maximal size of grains are $0.18 \mathrm{~mm}$ and $0.12 \mathrm{~mm}$ respectively). 


\section{Żegocina Marls}

The Żegocina Marls (Figs. 1, 9) occur locally but belong to the Upper Cretaceous marly facies, together with the Węglówka and the Frydek Marls. These rocks and other facies equivalents of the latter marls, are slightly older or younger than the Campanian, the period of culmination of marly sedimentation in the Western Carpathian Basin (Bieda et al. 1963). These authors present examples from the Sub-Silesian Unit (Turonian Jastrzębia Marls that occur in Lanckorona Tectonic Zone, Campanian-Maastrichtian Radocza Marls near Wadowice, Cenomanian-Senonian Jasienica Marls near Myślenice) and in the Silesian Unit (Turonian Kaczyna Siliceous Marls).

The opinions concerning the origin of the Żegocina Marls are rather diversified. Skoczylas-Ciszewska (1960) placed them among the Węglówka Marls and Variegated Shales, considering them to be older than gray Frydek Marls and assigned them to the SubSilesian Unit. In her opinion, these marls are facies equivalents formed in different parts of the same basin. Similar opinion is expressed in the paper by Słomka et al. (2006). Its authors call the Żegocina Marls siliceous marls, similar to the Jasienica Marls, and consider them to be a facies variety of the Węglówka Marls, appearing on Sub-Silesian Ridge during the Campanian. In Koszarski's (1985b) opinion, the Żegocina Marls represent Turonian calcareous flysch, corresponding to the Siliceous-Fucoid Marls (Hołownia and Kropiwnik Marls) in the Skole Unit and to the Kaczyna Marls in the Silesian Unit. This author includes the Żegocina Marls into the Skole Unit, similar to Ślączka and Kamiński (1998c) who did not exclude the above-mentioned Skoczylas-Ciszewska (1960) interpretation. Jugowiec-Nazarkiewicz and Jankowski (2001) suspect a similarity of microfaunal assemblages of the Żegocina Marls, Węgierka Marls and Upper Cretaceous platform marls in Bonarka (Cracow). In their opinion, the Żegocina Marls are olistoliths that occur in the Frydek Marls or in the environments of cataclasites and tectonic melanges. According to this opinion, the Żegocina Marls, similar to the Węgierka Marls, would represent marls deposited primarily on the shelf and redeposited into deeper parts of basin in the form of olistoliths and calcareous mud. The Żegocina Marls occurring as intercalations in bottom part of the Rybie Sandstones and cover them can be regarded as redeposited from the shelf as mud. The occurrence of the Żegocina Marls among the Rybie Sandstones, considered to represent deposits of small submarine fans (Skoczylas-Ciszewska 1960), is interpreted by Jugowiec-Nazarkiewicz and Jankowski (2001) by the sea-level fluctuations in marginal part of the basin.

According to the present studies of three blocks of the Żegocina Marls (Fig. 9; Tables 9, 19), their lithologic-sedimentological features correspond in Ghibaudo's (1992) classification to the facies M (mud beds), subfacies $1 \mathrm{M}$ (laminated mud beds) and to the beds of $\mathrm{e}_{1} \mathrm{M}$ type (faintly parallel laminated mud), $\mathrm{e}_{1} \mathrm{e}_{2} \mathrm{M}$ (faintly parallel-laminated mud, graded to ungraded mud) and $\mathrm{c}_{0} \mathrm{eM}$ and less frequently to ceM (cross-lamination in fine sand, faintly laminated mud) (Table 20). The distinguished depositional intervals indicate that the suspension-settling process that was part of the sedimentation of the Żegocina Marls studied $\left(e_{1}\right)$, was episodically interrupted by deposition from traction currents $\left(e_{2}\right)$. Fine lenses of silt-sized grains, and less often of fine sand-sized ones (depositional intervals $\mathrm{c}_{0}$ and $\mathrm{c}$ respectively) document delicate reworking of sediments by bottom currents. Biogenic sedimentary structures (burrows) visible in the top parts of some beds indicate the 
presence of oxygen in the bottom water of the Żegocina Marls sedimentary environment, slow to moderate sedimentation and the reworking of deposits related to vital activity of organisms. The above-described features of the marl beds studied correspond to biogenic turbidites and muddy contourites, according to Stow's (1985) criteria.

According to the above-presented opinions of various authors on the origin of the Żegocina Marls outcropping in the Lanckorona-Żegocina Tectonic Zone, there are geological and microfaunistic criteria allowing to consider them, at least partly, to the rocks redeposited from shelf in already rigid form (olistoliths). These olistoliths, consisting of beds, formed as contourites, are in Ghibaudo's (1992) classification the component of facies MyG (muddy gravel beds). They represent clasts of intrabasinal provenance.

\section{Jasienica Marls}

The Jasienica Marls (Figs. 1, 10) are considered to be local Upper Cretaceous marly facies developed in the Sub-Silesian Basin. According to Bieda et al. (1963) the Jasienica Marls are among the earliest of the Upper Cretaceous marly facies to appear on the SubSilesian Ridge, as described in previous chapter. It is considered based on microfaunal studies, that the beginning of their sedimentation corresponds to the siliceous facies (Jasper Beds and Green Radiolaria Shales) underlying the Variegated Shales and the Węglówka Marls i.e. the main Upper Cretaceous marly facies. In Koszarski and Ślączka's (1973) opinion, siliceous facies close the stage of formation of the Outer Carpathian Basin, which gained its maximal range and depth (about $4000 \mathrm{~m}$ ) in this period. The following compressional stage resulted in local shallowing of the basin and the sedimentation of marly sediments in the areas where the depth is above the CCD level. The above-mentioned microfaunistic studies have shown that the Jasienica Marls can be considered to be the deposits indicative of the beginning of reconstitution of the Outer Carpathian Basin. It should be stressed, however, that Słomka et al. (2006) call both the Jasienica and Żegocina Marls siliceous marls and consider them to represent a facies equivalent of the Węglówka Marls that appear together with them on the Sub-Silesian Ridge i.e. in general but since the Campanian.

According to the present author's studies of the Jasienica Marls (Fig. 10; Tables 10, 19), their lithologic-sedimentological features correspond to Ghibaudo's (1992) M facies (mud beds), and less commonly the MS one (mud-sand couplets) (Tables 20). The M and MS facies are formed due to the action of turbidity currents of low density, transporting finegrained material. Among the sediments of these marls assigned to these two facies, the subfacies $\lg$ (laminated and graded to ungraded) was distinguished. The subfacies $\operatorname{lgM}$ is represented by beds of $\mathrm{e}_{1} \mathrm{e}_{2} \mathrm{M}$ type (faintly parallel-laminated mud, graded to ungraded mud) and the subfacies lgMS by beds of the be $e_{1} \mathrm{e}_{2} \mathrm{MS}$ type (parallel lamination in fine sand, faintly laminated mud, graded to ungraded mud). Depositional intervals $e_{1} e_{2}$, distinguished within these beds, indicate the superposition of two processes in the sedimentation of the Jasienica Marls studied: suspension setting mechanisms $\left(\mathrm{e}_{2}\right)$, interrupted episodically by deposition from traction $\left(\mathrm{e}_{1}\right)$. The deposition by traction currents is also documented by thin streaks of fine sand-sized grains beginning some marly beds (b). Marly beds underlain by sandstone can be related to the deposition from low-density turbidity currents. The appearance of discontinuous, wavy laminae in marl beds, defined by fine sand-sized grains 
indicates a reworking of sediments by bottom currents. Numerous bioturbations document the oxidizing conditions in the sedimentation environment. According to Stow's (1985) model, sedimentary (lamination) and biogenic (common burrows) structures within the beds of the Jasienica Marls that occur in the outcrops studied correspond to the features of biogenic turbidites and muddy contourites.

\subsubsection{Eocene-Oligocene Marls}

\section{Lącko Marls}

The Łącko Marls (Figs. 1, 11) are turbidites that originated during the maximal differentiation of sedimentation conditions in the Magura basin due to synsedimentary folding (Oszczypko 1992; Poprawa et al. 2006). These conditions are indicated, for example, by a change in activity and the migration of source areas documented for the Magura Sandstones by Bromowicz (1992a). According to the above author's studies (Bromowicz 1992a; Bromowicz, Górniak 1988), the sediment transport directions for marls and for sandstone-shaly flysch were perpendicular. It should be emphasized that there is until now lack of such information concerning other Carpathian marls.

Oszczypko (1992) distinguished five stages of evolution of the Magura Basin: the opening of the basin and Late Jurassic-Cenomanian pelagic sedimentation, three stages of flysch sedimentation forming three complete turbidite cycles and Early Miocene piggy back basin as the final stage. In this subdivision, the Lącko Marls appear in the third stage of evolution of the Magura Basin, distinguished as the second (Middle-Middle Eocene) turbidite cycle. It is opened by the Variegated Shales, grading upwards into thin-medium bedded turbidites with marly intercalations, followed by thick-bedded turbidites and thinbedded turbidites closing this sequence. Palaeogene sediments of the Magura Basin are lithologically differentiated and the boundaries between these facies are diachronic. Diachronic migration of facies in the basin is visible, related to the progradation of submarine fan from the south to the north (Bromowicz 1992a; Oszczypko 1992). The Łącko Marls were deposited in the central part of basin. It is considered that facies differentiation of the Palaeogene deposits in the Magura Basin was the effect of Late Cretaceous subduction at the contact of the Pieniny Basin and Central European Domain. This process caused a subsidence in the southern part of the Magura Basin and a southward shift of the shoreline due to marine transgression, particularly intense in Late Middle Eocene (Oszczypko, Oszczypko-Clowes 2006). It is accepted that at the beginning of the Eocene the formation of accretionary wedge in the Magura Basin had already started, as well as its northward progradation. Lateral facies changes, which took place in the Eocene Magura Basin, indicate that the subsidence in distal part of the basin was not compensated by deposition (accommodation was greater than sediment supply), which is a symptom of the stage of starved (underfilled) foreland basin (Poprawa et al. 2006).

Facies differentiation of Palaeogene deposits, particularly the local occurrence of the Łącko Marls, stimulated Nowak (1924) to distinguish facies zones in the Magura Basin. Four facies zones are accepted (from the south to the north): the Krynica Zone, Sacz Bystrzyca (Sącz) Zone, Rača (southern Gorlice) Zone and Siary (northern Gorlice) Zone. The occurrence of the Lącko Marls among Palaeogene deposits is characteristic of the 
Bystrzyca Zone. In deposits of the same age in other facies zones these marls do not appear or they occur only sporadically. During marly sedimentation in the Sącz Zone, sandstoneshaly flysch was deposited to the south in the Bystrzyca Sub-Basins, and further to the north variegated shales and sandstone-shaly flysch were deposited in the Rača and Siary Sub-Basins (Łabowa Variegated Shales and Beloveza Formations). Książkiewicz (1966a, 1974) reports on the occurrence of intercalations of the Lącko Marls within the Labowa Variegated Shales Formation (Pasierbiec Sandstone Member) in the Babia Góra region. It should be stressed that among the isochronous equivalents of the Łącko Marls in the Rača Zone (Polany near Grybów), a series of dacite-andesite tuffs and bentonites about $50 \mathrm{~m}$ thick was preserved (Sikora 1970).

It is thought that the Magura Basin was a westward inclined trough during the sedimentation of the Łącko Marls. The sedimentation of marls was related to submarine slumps. It should be also stressed that features of these marls such as: the occurrence of marls above submarine slumps, the lenticular shape of marl bodies, another distribution of thickness when compared to other rocks in this profile and different mineral composition indicate their separate character and provenance from another alimentation areas than the accompanying siliciclastic flysch deposits (Bromowicz 1992a, b; Bromowicz, Górniak 1988). In these authors opinion, the primary sediments for the Łącko Marls were redeposited from a shallow southern margin of the South-Magura Cordillera and transported to the axial zone of the Magura Basin by turbidity currents. Bromowicz (1992a) does not exclude redeposition of primary material of marls from submarine elevations separating Bystrzyca from the Krynica and Rača basins. The presence of such elevations is suggested by Oszczypko (1979). Redeposition of sediments from submarine ridges and shelf zones into deeper parts of basin was preceded by submarine slumps, stepping down perpendicularly to siliciclastic flysch material, transported from the east. The origin of the slumps was a catastrophic process, initiated by seismic quakes. Marls disappear toward the top of the Maszkowice Beds (Książkiewicz 1958; Węcławik 1969; Bromowicz 1992a) and this event is accompanied in some profiles by the appearance of variegated shales (Jazowsko Member vel Mniszek Variegated Shales). In some authors opinion, the appearance of these deposits is related to global eustatic sea-level rise at the end of Middle Eocene (Oszczypko, Oszczypko-Clowes 2006).

The Łącko Marls are a characteristic facies mainly of the Middle Eocene series of the Magura Unit (Oszczypko et al. 1990). However, according to some opinions, a characteristic feature of the Magura Basin during the period from the Early Eocene since its closure in the Early Miocene was a repeat of similar sedimentation conditions at different times and in its different parts. In the opinion of Bieda et al. (1963), the Middle Eocene marls of the Lącko type occur in the central part of the Magura Unit (Lącko Marls), whereas in the marginal part they are Upper Eocene in age (Sub-Magura vel Zembrzyce Beds). In Bromowicz's (1992a) opinion, the marly facies of Łącko type appear in the northern marginal part of the Magura Basin (Siary Zone) on the boundary of the EoceneOligocene (Zembrzyce Shales) and again in the Oligocene (Budzów vel Małastów Shales). Oszczypko-Clowes (2001), based on microfaunal investigations, considers the Zembrzyca Beds in the Rača and Siary zones (Late Eocene - Early Oligocene) to be facies equivalent of the Żeleźnikowa Formation (Middle Eocene). Moreover, this author suggests that the 
marly lithofacies of Łącko type appear again in the Early Miocene in the Rača (Zawada Formation) and Krynica zones (Kremna Formation).

According to the analysis of lithologic-sedimentological features of the beds of the Łącko Marls (Fig. 11; Tables 11, 19), in Ghibaudo's (1992) classification, they show the properties of three finest-grained facies: MS (mud-sand couplets), MT (mud-silt couplets) and M (mud beds) (Table 20). In Ghibaudo's (1992) opinion, the MS facies can be interpreted as incomplete, base-cut-out Bouma-type sequence. The M and MT facies originated due to the deposition from low-concentration turbidity currents composed of silt and mud. The appearance of 1 (laminated) subfacies in the MS and MT facies indicates the activity of tractional and bottom currents in the depositional environment of the Lacko Marls studied. Depositional interval b appearing in beds of arenaceous marls (SM facies) is evidence of the sedimentation during the activity of tractional transport. Depositional interval c (cross-lamination in sand), which occurs within beds of arenaceous marls, and $\mathrm{c}_{0}$ interval (cross-lamination in silt), which occur within nonarenaceous marly beds, indicates reworking of the sediments by bottom currents. Depositional interval $e_{2}$ (graded to ungraded mud) visible within beds of nonarenaceous marls documents the deposition from diluted turbidity currents with the settling of fine particles out of suspension and with the ponding of sediments in depressions of the sedimentary basin bottom. In Ghibaudo's (1992) opinion, in such conditions very thick beds of $\mathrm{e}_{2} \mathrm{M}$ type are formed. It should be emphasized that the nonarenaceous Łącko Marls beds are up to 10 meters thick (Table 11).

The above-mentioned facies, distinguished with respect to the lithologicsedimentological features of the Lącko Marl beds, record the deposition of fine-grained material. According to the analysis of beds internal structures of marls and Ghibaudo's (1992, Table 5) data for the deposits of low-concentration turbidity currents, they represent depositional acts composed of several phases: deposition by traction currents, suspension settling and reworking of sediments by bottom currents.

\section{Zembrzyce Marls (marls from the Zembrzyce Beds)}

The Zembrzyce Marls (Figs. 1, 12), similar to the Łącko Marls, are turbidites, which appeared in the fourth stage i.e. in the third Late Eocene-Oligocene turbidite cycle according to Oszczypko (1992). They very much resemble the Łącko Marls but appear later than them and in another part of the Magura Basin. This is explained by the tectonic disquiet that accompanied Palaeogene sedimentation in the Magura Basin (synorogenic sedimentation). As already mentioned in the characteristics of the Łącko Marls, the formation of an accretionary wedge in the Magura Basin at the beginning of the Eocene, was the cause of the same sedimentation conditions that were repeated in a different period and in various parts of the basin (Bromowicz 1992a; Oszczypko 1992; Oszczypko-Clowes 2001; Oszczypko, Oszczypko-Cloves 2006). This resulted in the appearance of lithologically similar deposits. In these authors opinion, the Zembrzyce Marls are a younger lithofacies of marls of the Lącko type, which appeared in northernmost part of the Magura basin, mainly in the northern Gorlice (Siary) Zone and - to a lesser degree - in the southern Gorlice (Rača) Zone.

During the sedimentation of the Zembrzyce Marls the conditions in the Siary zone were similar to those in the Bystrzyca Zone during sedimentation of the Lacko Marls 
(Bromowicz 1992a). During the sedimentation of the Zembrzyce Marls, the basin in the Siary Zone was narrow, elongate and asymmetric trough-shaped (confined basin), the axis of which was inclined to the west and the bottom to the south. This basin was limited on the north by the margins of the Silesian Cordillera and from the south by the northwardprogressing front of the accretionary wedge. Bromowicz (1992a) considers the Zembrzyce Beds and the Wątkowa Sandstones to be isochronous facies equivalents. In this author's opinion, the distribution of the Zembrzyce Beds facies allows them to be considered as the sediments of terminal parts of the distributory channels of the submarine fan of the Watkowa Sandstones. Marls from the Zembrzyce Beds are products of redeposition processes and occur as packages with a very thick fine-grained member. Transport directions visible in this deposit allow them to be related to the slumps that slid from the north slope of the basin (Bromowicz 1992a). The slumps transported starting material for the marls from the shelf to deeper parts of the basin. This conclusion is confirmed by the sequence of deposits: arenaceous marl is overlain by nonarenaceous one. Besides, a higher frequency percentage of submarine slumps in the profiles of the Zembrzyce Beds that abound in the marls can be observed. Leszczyński and Malata (2002) have stated that the Zembrzyce Beds form a continuous cover in the whole Siary Zone and in their opinion, they represent the ramp deposits, developing gradually from the SW along the margin of the basin. According to recent nannoplankton (Oszczypko-Clowes 2001) and microfaunal (Leszczyński, Malata 2002) studies, the Zembrzyce Marls facies appears in the western part of the Siary zone, mainly in Late Eocene (Priabonian), and in eastern part in the Early Oligocene (Rupelian). Consequently, the age of the Zembrzyce Beds sensu lato is considered to be diachronous. In many authors opinion, such sedimentation conditions in the Siary Zone were both due to tectonic and eustatic conditions: shortening of the basin and falling of the level of global ocean on the boundary of the Eocene/Oligocene. It should be emphasized that this shortening of the basin during sedimentation of the Zembrzyce Marls was caused by tectonic activity related to volcanism. Synsedimentary calc-alkaline volcanism is documented by the occurrence of bentonitized tuffites in the Zembrzyce Beds, outcropping in Pewel Mała, Zembrzyce and Budzów (Cieszkowski et al. 1985; Książkiewicz 1966b, c, 1974). Two of them were dated: tuffites from Pewel Mała were found to be $36.9 \pm 1.9 \mathrm{Ma}$ in age (Cieszkowski et al. 1985) and dacite-andesite tuffs in the Szymbark Shales in Folusz (Sikora 1970), facies equivalent of the Zembrzyce Beds in the Siary Zone, in the area to the east of the Dunajec River - 32.9 $\pm 1.3 \mathrm{Ma}$ (Van Couvering et al. 1981). A global fall sea level at the boundary of the Eocene/Oligocene is considered to be the cause of the Globigerina Marls-dominated sedimentation in all Western Carpathian sub-basins, except the Magura Basin. According to Oszczypko-Clowes (2001), in the Siary Zone the boundary of the Eocene/Oligocene is located locally within the Zembrzyce Beds, Wątkowa Sandstones and Budzów Beds. Numerous authors drew attention to the similarity of microfaunal assemblages occurring in the Zembrzyce Beds and the Globigerina Marls (e.g. Blaicher 1961; Bieda et al. 1963; Cieszkowski et al. 1985; Leszczyński, Malata 2002). Moreover, in the eastern part of the Siary Zone, the Szymbark Shales are considered to be the equivalent of the Zembrzyce Beds, and there are intercalations of menilite-type shales, resembling the Menilite Shales that occur above the Globigerina Marls (Ślączka, Kamiński 1998f). The similarity of microfauna in the Globigerina Marls and the Zembrzyce Marls documents the influence of global factors on the conditions of sedimentation (global drop 
in the $\mathrm{CCD}$ ) in the Magura Basin in the Siary Zone on the boundary of the Eocene/Oligocene. Lithologic differentiation of the facies equivalent of the Globigerina Marls occurring in the Siary Zone of the Magura Basin documents the influence of local tectonic causes (synsedimentary shortening of the basin) and accompanying volcanism. It is thought that the lithologic development of the Zembrzyce Marls is the result of these factors but to a different degree.

According to the studies of outcrops of the Zembrzyce Marls in Zembrzyce and in Budzów (Fig. 12; Tables 12a-c, 19), the lithologic-sedimentological features of their beds correspond to the three finest-grained facies distinguished in Ghibaudo's (1992) classification: MS (mud-sand couplets), MT (mud-silt couplets) and M (mud beds) (Table 20). Marly division (nonarenaceous marl) distinctly dominates in bipartite beds belonging to the MS and MT facies (Fig. 12). A basal, coarser-grained division (arenaceous marl) of these beds contains more grains of fine sand-sized (MS facies) and silt-sized (MT facies). Both of these facies, and sometimes also the $\mathrm{M}$ facies, are represented by subfacies $\mathrm{lg}$ (laminated sandy and silty division, graded to ungraded mud), indicating the activity of currents reworking sediments in their sedimentation environment. Common crosslamination in arenaceous marls, corresponding to depositional intervals c (cross lamination in sand) and $\mathrm{c}_{0}$ (cross lamination in silt), initiating the bipartite beds belonging to the MS and MT facies documents the reworking of sediments by bottom currents. Depositional intervals $b$ (parallel lamination in sand) and $d$ (parallel lamination in silt), which usually appear in such beds above $\mathrm{c}$ and $\mathrm{c}_{0}$ intervals, document the deposition by traction transport. Depositional interval $e_{1}$ (faintly parallel laminated mud), which occurs in beds of nonarenaceous marls belonging to the $\mathrm{M}$ facies, documents the deposition from the traction, interrupting episodic suspension settling. The last of the above-mentioned processes is recorded as depositional interval $e_{2}$ (graded to ungraded mud) that occurs in some nonarenaceous marl beds ( $\mathrm{M}$ facies) and in marly division of composite beds belonging to the MT and MS facies. According to Ghibaudo (1992), very thick beds of $\mathrm{e}_{2} \mathrm{M}$ type document the deposition from diluted turbidity currents with the settling of fine particles from suspension, and their deposition with ponding in depressions of the basinal bottom. It should be emphasized that in the profiled outcrops of the Zembrzyce Marls, the thickest beds of nonarenaceous variety are up to $250 \mathrm{~cm}$ thick (Table $12 \mathrm{a}-\mathrm{c}$ ).

The distinguished facies of the Zembrzyce Marls are a record of deposition of finegrained material and may represent base-cut-out Bouma sequence. According to the analysis of the bed's internal structures and Ghibaudo's (1992, Table 5) data for the deposits of low-concentration turbidity currents, marly beds represent depositional acts composed of several phases: deposition from traction, settling from suspension and intense reworking of sediments by bottom currents. Similar to the case of the Lacko Marls, very thick packages of nonarenaceous variety of the Zembrzyce Marls that are attributed to the $\mathrm{M}$ facies and form marly division of bipartite beds belonging to the MS and MT facies, can be related to their deposition in depressions of the bottom.

\section{Budzów Marls (marls from the Budzów Beds)}

The Budzów Marls (Figs. 1, 13) are turbidites, like the Łącko and Zembrzyce Marls. Following the previously presented evolution of the Magura Basin according to Oszczypko 
(1992), the Budzów Marls close the fourth i.e. the third turbiditic Late Eocene- Oligocene stage. According to current opinions on the depositional conditions in Eocene-Oligocene Magura Basin, the Budzów Marls represent successive, younger lithofacies of marls of the Łącko type. All these marls are lithologically very similar (Bieda et al. 1963; Książkiewicz 1966a, 1974; Bromowicz 1992a).

During the deposition of the Budzów Marls in the Siary Zone the conditions of sedimentation were similar to those of the deposition of the Zembrzyce Marls (Bromowicz 1992a; Oszczypko, Oszczypko-Clowes 2006). The appearance of shaly-marly deposits (Budzów Beds, Małastów Shales) above the sandy one (Magura Sandstones, Wątkowa Sandstones) indicate, in Bromowicz's (1992a) opinion, migration and disappearance of activity of the source area for sandstones. It can thus be concluded that during sedimentation of the Budzów Beds the Magura Basin was subjected to synsedimentary shortening. This thesis is confirmed by the diachronous character of both the lower and upper boundary of the Budzów vel Małastów Beds. Microfaunal and nannoplankton studies show evidence that shaly-marly member closing sedimentation of the Magura Beds in the Siary Zone in the area west of Dunajec appears at the beginning of the Early Oligocene, and locally at the boundary of the Eocene/Oligocene, and in the area east of Dunajec at the end of the Early Oligocene (Birkenmajer, Dudziak 1988; Oszczypko-Clowes 2001; Leszczyński, Malata 2002). It should be also remembered that Oszczypko and OszczypkoClowes (2006) have named the Budzów Beds as resedimented marly mudstones, which appear in the northern part of the Magura Basin, which was deepest in that time, as numerous intercalations in the Magura Sandstones of the glauconitic facies. In these authors' opinions, such sedimentation lasted from the Late Eocene to the Middle Oligocene. It should be emphasized that the shortening of the basin accompanying the sedimentation of the Budzów and Zembrzyce Marls was caused by tectonic activity related to volcanism. In the Budzów Marls, these phenomena are evident by the occurrence of tuffites in the outcrop in Krzczonów, reported by Leszczyński and Malata (2002).

According to the above author's opinion, marls appearing among the Magura Sandstones from the Eocene to the Oligocene are lithologically similar and contain redeposited microfauna. Marl-bearing complexes (Łącko, Zembrzyce and Budzów Beds) form lenticular bodies. Moreover, it is evidence that the Łącko Marls were transported from another direction to the sandstones. These features indicate the appearance of similar sedimentation models in the sub-basins of the Magura Basin, caused by similar surroundings. Such conditions appeared in central part of the Magura Basin in the Middle Eocene (Łącko Marls) and in its northern part in the Upper Eocene (Zembrzyce Marls) and again in Lower Oligocene (Budzów Marls). The repetition of similar environments in different sub-basins of the Magura Basin, and of the causes responsible for catastrophic resedimentation of parent deposits of the marls in question, were related to synsedimentary closing of this basin. In Oszczypko-Clowes's (2001) opinion, nannoplankton studies have shown that the Budzów Beds are in the Siary Zone an facies equivalent to the Malcov Formation.

According to the present author's studies of the outcrop of the Budzów Marls (Fig. 13; Tables 13, 19), lithologic-sedimentological features of their beds correspond to the three finest-grained facies in Ghibaudo's (1992) classification: MS (mud-sand couplets), MT (mud-silt couplets) and M (mud beds) (Table 20). In the bipartite beds, with arenaceous 
marls (sandy division) in the bottom and nonarenaceous marls (muddy division in the top), assigned to the MS facies, the sand/mud thickness ratio generally varies from 1:1 to 1:5 and is typical for the base-cut Bouma-type sequence (Ghibaudo 1992). All of the abovementioned facies that are distinguished in the profile of the Budzów Marls are represented by subfacies $1 g$ (laminated, graded to ungraded mud). Only some beds of nonarenaceous marls can be assigned to subfacies $g$ (Table 20). Subfacies 1 indicates the activity of currents and subfacies $\mathrm{g}$ is interpreted as indicating sediments deposited by suspension settling mechanism (Ghibaudo 1992). Depositional interval b (parallel lamination in sand) and $\mathrm{d}$ (parallel lamination in silt), visible in sandy and silty parts of composite beds belonging to the subfacies IMS and IMT respectively, are evidence of the deposition by traction currents. Depositional interval $\mathrm{e}_{1}$ (faintly parallel laminated mud), which appears in nonarenaceous marls assigned to the $\mathrm{M}$ facies and which occur in the upper, mud division of composite beds belonging to the MS and MT ones, documents the deposition from traction, interrupting episodic sedimentation due to settling from suspension. Depositional interval c (cross-lamination in sand), visible in the bottom sandy division of composite beds, documents the reworking process of sediments by bottom currents. Moreover, the very thin, lenticular, discontinuous laminae in silt, visible locally in nonarenaceous marl beds (depositional interval $\mathrm{c}_{0}$ ) are interpreted as fading- ripple lamination (Stow 1984). It is worth adding that the thick and very thick beds of nonarenaceous marls distinguish the Budzów Marls. This variety of marls, especially those forming beds with the thicker depositional interval $e_{2}$ (graded to ungraded mud), may be considered, based on features proposed by Ghibaudo (1992), to reflect the ponding of fine grained turbidite currents in relatively restricted basins or part of basin (bottom depressions).

According to the presented analysis, the facies distinguished based on the lithologicsedimentological features of Budzów Marl beds are evidence of the deposition of finegrained material and may represent a base-cut Bouma sequence. According to the analysis of bed's internal structures of marls and Ghibaudo's (1992, Table 5) data for the deposits of low-concentration turbidity currents, these beds represent depositional acts consisting of several phases: deposition from traction, suspension settling mechanism and reworking of sediments by bottom currents. Similar to the case of the Łącko and Zembrzyce Marls, the considerable thickness of the marly division (nonarenaceous variety) visible in the Budzów Marl beds can be related to their deposition in bottom depressions.

\section{Leluchów Marls}

The Leluchów Marls (Figs. 1, 14) are considered to be pelagic sediments (Oszczypko, Oszczypko-Cloves 2006) based on nannoplankton studies (Oszczypko 1996). In accordance with the previously presented five stages of evolution of the Magura Basin (Oszczypko 1992), the Leluchów Marls, similar to the Budzów Marls, appear in the fourth stage i.e. during the third (Late Eocene-Oligocene) turbidite cycle.

The Leluchów Marls that appear locally in the Magura Basin are considered to be the lithostratigraphic equivalent of the Sub-Menilite Globigerina Marls (Birkenmajer, Oszczypko 1989). Based on microfaunal investigation (Olszewska, Malata 2006), it is accepted that the Sub-Menilite Globigerina Marls were formed at the Eocene/Oligocene boundary under conditions of a global fall in sea-level and drop in the CCD. The origin of 
such sedimentation conditions was due to rapid tectonic uplift of basins of the Outer Carpathians at the boundary of the Eocene/Oligocene, resulting from regional compression. This event, recorded in the architecture of the basin-fill, is correlated to the Illyrian phase of intensified tectonic activity in the European Alpides (Poprawa et al. 2006). In the evolution of the Magura Basin, the appearance of the Globigerina Marls is considered to be evidence of the progressive shallowing of this basin, initiated in its southern part (Oszczypko, Oszczypko-Cloves 2006). It should be remembered that in both deposits underlying the Leluchów Marls (Mniszek Shales) and in overlaying them (Smreczek Shales), there are intercalations of tuffites, correlated to those of the Polany and Gąsiory (36.4 $\pm 1.4 \mathrm{Ma})$ horizons (Birkenmajer, Oszczypko 1989).

According to the studies of Leszczyński (1997) on the conditions of sedimentation of the Sub-Menilite Globigerina Marls, their differentiation of lithology and sedimentary structures allows them to distinguish between hemipelagites, less common pelagites, turbidites and contourites. In this author's opinion, light, structureless marls typical of this sequence correspond, in the classification of Pickering et al. (1986), to nanno-foram muddy oozes, and were formed mainly by settling through the water column with some contribution from lateral transport by near bottom currents (contourites).

The present author's studies of grain-size distribution of the Leluchów Marls (Fig. 14; Tables 14, 19) have shown that they can be assigned to two of Ghibaudo's (1992) finestgrained facies: M (mud beds) and MT (mud-silt couplets) (Table 20). The subfacies gM (graded beds) and beds of the $\mathrm{e}_{2} \mathrm{M}$ type (graded to ungraded mud) document settling of the particles through the water column $\left(\mathrm{e}_{2}\right)$ whereas subfacies $\operatorname{lgM}$ (laminated to graded beds) and beds of $\mathrm{e}_{1} \mathrm{e}_{2} \mathrm{M}$ type (faintly parallel-laminated mud, graded to ungraded mud) document sedimentation from traction currents $\left(\mathrm{e}_{1}\right)$, episodically interrupting sedimentation by settling of grains from suspension $\left(\mathrm{e}_{2}\right)$. Sedimentation from traction currents (depositional intervals $d$ and $e_{1}$ ) is also documented by subfacies IMT (laminated mud-silt couplets) and beds of the de ${ }_{1}$ MT type (alternating planar, irregular silt and mud laminae, faintly parallellaminated mud) estimated within sediments belonging to the MT facies.

The differentiation in colour of the Leluchów Marls can be related to the conditions of their sedimentation and early diagenesis. A generally accepted model that links the change of red colour, characteristic of sediments deposited on the oceanic bottom under oxidizing conditions, with increased supply of organic matter (Gardner et al. 1978), can be applied to the Leluchów Marls. The availability of oxygen in bottom sediments is documented by numerous bioturbations visible in these marls.

According to the present studies, the profiled sequence of the Leluchów Marls was formed due to the depositional processes of settling of particles through the water column that was interrupted more or less often by deposition from traction currents. The contribution of the latter process was often obliterated by reworking of sediment by burrowing.

\section{Niwa Marls (marls from the Malcov Beds)}

The Niwa Marls (marls from the Malcov Beds) (Figs. 1, 15) are also turbidites. The environs of Niwa near Nowy Targ, where these marls occur, are situated within the Krynica facies zone of the Magura Unit; nevertheless, the Malcov Beds were already deposited in 
changed paleogeographic conditions (Oszczypko, Oszczypko-Clowes 2006). The Malcov Beds discordantly overlie sandstones of the Magura Formation (muscovite facies), and in the Nowy Targ region they are the youngest deposits of the Magura Unit. This discordance is considered as evidence of a reconstitution of the Magura Basin during sedimentation of the Malcov Beds (Oszczypko, Oszczypko-Gloves 2006). In Oszczypko's (1992) opinion, the sedimentation of the Malcov Beds closed the penultimate (fourth) stage of evolution of the Magura Basin i.e. the third Late Eocene-Oligocene turbidite cycle. In this period, further progradation of the accretionary wedge in the Magura Basin took place by submarine folding of the Eocene sediments. At the end of the Oligocene, the front of the Magura Nappe was formed. It should be emphasized that in some authors' opinions (Poprawa et al. 2006) the Malcov Beds were deposited in a piggy-back basin, closing the evolution of the Magura Basin. The Malcov Basin was superposed on partly folded deposits of the Krynica and Bystrzyca Sub-Units (Oszczypko 2006).

According to the present author's studies of the Malcov Beds (Fig. 15; Tables 15, 19), the lithologic-sedimentological features of their beds correspond to three finest grained facies distinguished by Ghibaudo (1992): MS (mud-sand couplets), MT (mud-silt couplets) and $\mathrm{M}$ (mud beds) (Table 20). All of the facies mentioned are represented by subfacies 1 (laminated), indicating the action of currents reworking the sediments in the environment of deposition of marls. Cross-lamination, common in the arenaceous variety of marls studied, corresponds to depositional intervals $\mathrm{c}$ (cross lamination in sand) and $\mathrm{c}_{0}$ (cross-lamination in silt), initiating bipartite beds (arenaceous marl-nonarenaceous marl), belonging to the facies MS and MT, documents the reworking of sediments by bottom currents. Depositional interval $e_{1}$ (faintly parallel laminated mud), which occurs in beds of nonarenaceous marls belonging to the $\mathrm{M}$ facies and appears in the upper muddy division of bipartite beds (arenaceous marl-nonarenaceous marl couplet) as well, documents the deposition from traction, episodically interrupting settling in water column, represented by interval $e_{2}$ (graded to ungraded mud). Relatively dense lamination by streaks of silt, visible in nonarenaceous beds, indicates a significant contribution of the former process.

The above-distinguished facies in the studied fragment of profile of the Niwa Marls refer to the deposition of fine-grained material. According to Ghibaudo (1992), the MS and MT facies can be interpreted as an incomplete, base-cut-out Bouma sequence and explained by the deposition of mud-sand and mud-silt couplets from low-concentration turbidity currents, composed of very fine sand, silt and mud. According to the analysis of internal structures of beds and Ghibaudo's (1992, Table 5) data for the deposits of lowconcentration turbidity currents, they represent depositional acts composed of three phases: deposition from traction, settling from suspension and reworking of sediments by bottom currents.

\section{Grybów Marls}

The Grybów Marls (Figs. 1, 16) are turbidites (Ślączka, Kamiński 1998d; OszczypkoClowes, Ślączka 2006). According to recent opinions, the Grybów Marls were deposited in the Fore-Magura (Grybów-Dukla) Basin during maximum shallowing of the Outer Carpathian Basin and its separation from the global ocean. These events resulted in limitation of the water circulation and a deficit of oxygen in sedimentation environments. 
As already mentioned, this reconstitution of the Outer Carpathian Basin on the boundary of the Eocene/Oligocene was caused by regional compression. Simultaneously, further progradation of the accretionary wedge in the southern part of the Magura Basin took place. The Outer Carpathian Basin was transformed from remnant oceanic into foreland basin in this period (Oszczypko 1999). It should be emphasized that this reconstitution was accompanied by volcanic activity, evident by the tuffites (Gąsiory horizon) preserved in the Sub-Cherts Menilite Beds of the Silesian and Skole Units (Koszarski, Wieser 1960). This tuff was dated by Van Couvering et al. (1981) to $34.6 \pm 1.4$ Ma. Sikora (1970) reported thin tuffitic intercalations, occurring in Sub-Cherts Menilite Beds, facies substituting the SubGrybów and the Grybów Beds in the Ropa Tectonic Window. It should be stressed that the Gąsiory horizon was first considered to be andesitic (Koszarski, Wieser 1960), but detailed studies of the morphology of zircon crystals in these tuffites indicate them to be rhyolitic (Wieser 1985).

According to lithologic studies of the Grybów Marls (Fig. 16; Tables 16, 19), they represent three finest grained facies distinguished in Ghibaudo (1992) classification scheme: the MS (mud-sand couplets) and MT (mud-silt couplets) with distinct dominance of nonarenaceous marly division (usually the ratio is 1:20) and the $\mathrm{M}$ facies (mud beds) (Table 20). The lg subfacies (laminated to graded beds), which occurs in the MS and MT facies, indicates the activity of currents reworking sediments in the environments of sedimentation of the marls in question. The lgMS surfaces, represented by beds with the depositional interval be $\mathrm{e}_{2} \mathrm{MT}$ (parallel lamination in sand, faintly parallel-laminated mud, graded interval in mud) and lgMT subfacies, represented by beds with the depositional interval $\mathrm{de}_{1} \mathrm{e}_{2}$ MT (alternating planar and wavy irregular silt and mud laminae, faintly parallel-laminated mud, graded to ungraded mud) is a record of sedimentation during the tractional transport (depositional intervals $b, d$ ), gradually substituted by the settling of suspension from water column (depositional intervals $\mathrm{e}_{1} \mathrm{e}_{2}$ ). The beds of nonarenaceous marls that are distinguished as $\mathrm{M}$ facies and $\mathrm{gM}$ subfacies (graded beds) and beds of the $\mathrm{e}_{2} \mathrm{M}$ type (graded to ungraded mud) document the last of the mentioned processes. Due to the homogeneous dark colour of these marls, the mode of distribution of coarser grains (fine silty fraction), which occur in the bottom part of beds of the gM subfacies, can only be estimated during microscope examination. The local distribution of silt-sized grains in streaks indicates the contribution of traction to their deposition (tractional grain-by-grain deposition from suspension). It should be remembered that very thick beds of $\mathrm{e}_{2} \mathrm{M}$ type are related to deposition from diluted turbidity currents with settling of fine particles from suspension and their deposition with ponding in depressions of sedimentary basin bottom (Ghibaudo 1992). In the profiled fragment of the Grybów Marls, the thickest beds of nonarenaceous marls are more than $10 \mathrm{~m}$ thick (Fig. 16; Table 16).

The facies recognized with respect to the lithologic-sedimentological features of the Grybów Marls beds, indicate the deposition of fine-grained material and may represent a base-cut-out of the Bouma sequence. According to the analysis of internal structure of beds and Ghibaudo's (1992, Table 5) data for the deposits of low-concentration turbidity currents, they represent depositional acts composed of sedimentation by traction and suspension settling mechanisms (tractive-suspentional mode of deposition). Similar to the case of other the marls of the Lącko type (Łącko, Zembrzyce and Budzów Marls), a considerable thickness of nonarenaceous marly member, visible in the Grybów Marls, can 
reflect the ponding of fine-grained turbidity currents in the bottom depressions of a basin that was probably relatively restricted.

\section{Sub-Cergowa (Jawornik) Marls}

The Sub-Cergowa Marls (Figs. 1, 17) are also turbidites (Ślączka, Kamiński 1998e) and their sedimentation is considered to be related to the Late Eocene-Oligocene reconstitution of the whole Outer Carpathian basin (Koszarski 1963; Oszczypko 2006). The Sub-Cergowa Marls, similar to the Grybów ones, were formed in an early stage of unification of sedimentation conditions in the Outer Carpathian Basin, caused by this reconstitution. As already mentioned, it is recently accepted that the abrupt uplift, shallowing and reconstitution of the whole Outer Carpathian Basin and its isolation from the global ocean, which resulted in an oxygen-depleted sedimentary environment, was initiated at the boundary of the Eocene/Oligocene and was caused by compression in the European Alpides (Oszczypko 2006; Poprawa et al. 2006).

The initial stage of unification of sedimentation in the whole Outer Carpathian Basin is indicated by the appearance of the Green Shales and the Globigerina Marls underlying the Menilite Beds that are considered to be a continuation of this process (Oszczypko 2006). The differences in evolution of the Menilite Formation in the Dukla and For-Dukla zone are the effect of evolution of the Dukla Basin. This basin was periodically associated with the Silesian or Magura Basin. Separated on the boundary of the Lower and Upper Cretaceous, and particularly in the Eocene, on the boundary of the Eocene/Oligocene it changed the configuration of its bottom and was again linked with the Silesian Basin (Ślączka 1971, 1977a, 1985; Koszarski 1985e). However, the differences in the development of the Menilite Beds in the Dukla and For-Dukla zone indicate that in the Oligocene a submarine ridge separating the Dukla and Silesian Basins still existed (at least in the eastern part) (Ślączka 1971).

The Menilite Formation grades continuously into deposits of the Krosno Formation, closing sedimentation in the Dukla zone. Transition deposits indicate the overlapping of both facies and the incorporation of the Dukla facies zone into the basin where the Krosno Beds were deposited. The Krosno Beds close the unification of sedimentation in the whole Outer Carpathian Basin. In the Dukla zone their thickness is up to $600 \mathrm{~m}$. However, their occurrence is limited to only the northern part of the Dukla Unit. It is accepted that sedimentation in the Dukla Basin was closed in Upper Oligocene. Also, from the end of Eocene until Oligocene in the Dukla basin, a migration of its depocentre from the south to the north is marked (Ślączka 1977a). This was related to the closing of the Magura basin. At the end of the Oligocene, the front of the Magura nappe was formed, which was thrust over sediments of the Fore-Magura (Grybów-Dukla) zone in submarine conditions (Oszczypko, Oszczypko-Clowes 2006). Consequently, the Lower Oligocene Sub-Cergowa (Jawornik) Marls can be considered to be deposits that represent a continuation of synorogenic sedimentation, initiated in the Magura basin during the Early Eocene. Primary sediments, which were the source material of these marls, were deposited on submarine ridges, separating sub-basins in the Fore-Magura zone (Ślączka 1971; Oszczypko, Oszczypko-Clowes 2006). Afterwards, they were redeposited into deeper parts of the Dukla Basin, which was shortening simultaneously with the migration of the accretionary wedge 
that was forming in the Magura Basin. Tectonic activity was accompanied by volcanic phenomena, documented by the occurrence of tuffites (Gąsiory horizon) in the Sub-Cherts Menilite Beds of the Skole, Silesian and Grybów Units (Koszarski, Wieser 1960; Sikora 1970; Wieser 1985) that are $34.6 \pm 1.4 \mathrm{Ma}$ in age (Van Couvering et al. 1981).

It is worth mentioning the lateral variability and resemblance of the Sub-Cergowa Marls to the Dusin and Grybów ones (Ślączka 1971, 1977a, 1985; Oszczypko-Clowes, Ślączka 2006; Oszczypko-Clowes, Oszczypko 2011). Lithologic similarity of the Sub-Cergowa and the Grybów Marls was already noted by Bieda et al. (1963). In Koszarski, Koszarski's (1985c) opinion, the Sub-Cergowa and Eocene Lącko Marls of the Magura Unit are also lithologically similar. These authors affirm that marls of the Sub-Cergowa type appear in the Lower Oligocene Cherts Beds of the Menilite Formation of the Silesian and Skole units (Dynów Marls). It may be concluded that from the Early Oligocene during successive closure of the Fore-Magura, Silesian and Skole basins, favouring conditions were formed for the sedimentation of lithologically similar marls. As already mentioned in the characteristics of marls occurring in the Magura Unit, the formation of the accretionary wedge at the beginning of the Eocene was the cause of the repeating sedimentation conditions in a different period and in different parts of the Outer Carpathian Basin (Bromowicz 1992a; Oszczypko 1992; Oszczypko-Clowes 2001; Oszczypko, OszczypkoClowes 2006). This resulted in the appearance of lithologically similar marls.

According to the present author's studies of the Sub-Cergowa (Jawornik) Marls (Fig. 17; Tables 17, 19), lithologic-sedimentological features of their beds correspond to finegrained facies distinguished in Ghibaudo's (1992) classification: M (mud beds) and MS (mud-sand couplets) (Fig. 17; Table 20). In both of these facies the subfacies lg was distinguished (laminated to graded mud), indicating the activity of currents reworking sediments in the sedimentation environment of marls. Depositional intervals $e_{1}$ (faintly parallel laminated mud) and $e_{2}$ (graded to ungraded mud), which occur in marly beds belonging to $\mathrm{M}$ facies and in muddy division, distinguished in bipartite beds, attributed to facies MS document the deposition from suspension with tractional grain segregation and the suspension fall-out, respectively. The record of sedimentation during traction transport from low-density turbidity currents, which earlier deposited coarse-grained material, is depositional interval $\mathrm{b}$ (parallel lamination in sand), estimated in arenaceous member of bipartite beds belonging to the MS facies. On the other side, depositional interval c (crosslamination in sand) indicates reworking of sediments by bottom currents. The differentiation in colouration of the Sub-Cergowa Marls indicates a variable supply of organic matter, and bioturbations visible particularly in the light-coloured marls indicate that there was at least periodical availability of oxygen in the bottom sediments.

The facies distinguished on the basis of lithologic-sedimentological features of the SubCergowa (Jawornik) Marls document the deposition of fine-grained material and may represent a base-cut-out Bouma-type sequence. According to the analysis of the internal structure of marly beds and Ghibaudo's (1992, Table 5) data for the deposits of lowconcentration turbidity currents, they represent depositional acts composed of several phases: deposition from traction, reworking of sediments by bottom currents and suspension settling mechanisms. 


\section{Dynów Marls}

The Dynów Marls (Figs. 1, 18), in Kotlarczyk's (1985) opinion, may be considered to be fine-grained tractionites and partly turbidites. Taking into account the subdivision of the history of the Skole Basin into four phases (Kotlarczyk 1985), the Dynów Marls appeared at the beginning of the fourth (last) Oligocene-Lower Miocene one. At the beginning of this phase (Late Eocene-Early Oligocene), the Skole Basin was subjected to violent uplift, shallowing and separation from the global ocean, similar to all the basins of the Outer Carpathians, with the exception of the northern part of the Magura Basin. As already mentioned in the characteristics of the Grybów and Sub-Cergowa Marls, this Late Miocene-Oligocene transformation resulted in the unification of sedimentation conditions in nearly the whole Outer Carpathian Basin. The initial deposition of the Green Shales and the Globigerina Marls was followed by the formation of dark, bituminous the Menilite Beds, grading upwards into the Krosno Beds, closing this sedimentation period (Oszczypko 2006). It should be emphasized that the sedimentation rate of the lower part of the Menilite Beds is considered to be rather low, amounting to 25-35 m/Ma (Malata, Poprawa 2006).

The environmental condition and processes of the Dynów Marls sedimentation are given by Kotlarczyk (1985). Based on analysis of sediment transport directions, bathymetric data and sedimentary structures, this author suggests that the parent sediments, from which the Dynów Marls were formed after diagenesis, were transported by weak currents from the SSE i.e. parallel to the margin of basin (i.e. contour currents). Coarsergrained sediments, from which the Kliwa Sandstones were formed, were transported in the same direction. The Kliwia Sandstones consist of material that came from northern shore of the basin, was reworked on the shelf and transported into deeper parts of basin by traction currents. According to these data, the Dynów Marls can be considered, similar to sandstones of Kliwa type, to be finer grained tractionites. Some structural varieties of the Dynów Marls may be considered to be turbidites (varieties containing gradationally distributed lithoclasts). According to the examination of fishes and frequently visible deformation of beds caused by slumps, parent sediments of the Dynów Marls were deposited at the foot of continental slope. Studies of Kotlarczyk and Leśniak (1990) indicate that the nannoplankton building the Dynów Marls was transported by the distributory channels of submarine fans from the marginal zone of the Skole Basin down the slope (to the SE) during a diminished supply of clastic material. Parent sediments, from which the Dynów Marls were formed after diagenesis, were deposited mainly in channel zones and partly between distributory channels. These channels were, in general, not moving but their activity was variable during sedimentation of the Menilite Formation (Kotlarczyk, Leśniak 1990).

According to the present author's studies of the Dynów Marls (Fig. 18; Tables 18, 19), lithologic-sedimentological features of their beds that were described in the previous chapter correspond to the fine-grained facies in Ghibaudo's (1992) classification: the MS (mud-sand couplets) and M (mud beds). Depositional interval c (cross-lamination in sand), which occurs in the sandy division of composite beds, documents the reworking of sediments by bottom currents. Depositional interval $e_{2}$ (graded to ungraded mud), which appears in the mud division of the composite beds, documents the process of settling of suspension though water column. The occurrence of depositional interval $\mathrm{e}_{1}$ (faintly parallel 
laminated mud) documents the deposition from traction currents, interrupting episodically the former process.

The facies that are distinguished on the basis of lithologic-sedimentological features of the Dynów Marls document the deposition of fine-grained material and may represent a base-cut-out Bouma-type sequence. According to the analysis of internal structure of beds and Ghibaudo's (1992, Table 5) data for the deposits of low-concentration turbidity currents, they document several phases of depositional acts: settling from suspension interrupted occasionally by sedimentation from traction currents and reworking of sediments by bottom currents. The last of these processes is most evident in the lower part of the Dynów Marls sequence. In the upper part the intense deposition from traction currents is more marked. The frequently visible deformation of beds by submarine flows is evidence that sedimentation of the Dynów Marls proceeded under conditions of tectonic inquietude.

According to the present author's studies, the Dynów Marls closely resemble the SubCergowa ones. This fact was mentioned already by Bieda et al. (1963) but also by Koszarski and Koszarski (1985), who called them marls of the Sub-Cergowa type. The appearance of the Sub-Cergowa Marls in a lower horizon than the Dynów Marls in the profile of the Menilite Formation in the Dukla and Skole zones resembles the occurrence of the Lącko, Zembrzyce and Budzów Marls in the profile of the Magura Formation in the Bystrzyca and Siary zones of the Magura Basin. This conclusion confirms Bromowicz's (1992a) opinion on the repetition of conditions that favour the appearance of marls at different times and different parts of synorogenic sedimentary basins. During the Eocene period it was the Magura Basin, and in the Oligocene it was successively the Fore-Magura and Skole basins. The Dynów Marls in the Skole Unit, similar to the Sub-Cergowa and the Grybów Marls in the Fore-Magura Unit and the Łącko, Zembrzyce and Budzów Marls in the Magura Unit, indicate the closing of the Outer Carpathian Basin. It is a diachronous process, initiated at the boundary of the Palaeocene/Eocene in the Magura Basin, and successively included more outer basins. On the boundary of the Eocene/Oligocene it was marked in the Dukla zone and at the end of Oligocene in the Skole zone (Oszczypko 2006).

\section{Conclusions}

Based on the present author's studies, it is concluded that similar conditions that favoured the sedimentation of marls took place at different times and different sedimentation basins of the Outer Carpathians. Lithologic properties of marls (Tables 4-20) have recorded similar coexistence of depositional processes, acting with different intensity.

The colour of marls: black, gray with bluish or green tint, dark- and light-brown, variegated and red, documents a variable amount of remnant organic matter. This differentiation is linked to the variable relations between the flux of organic matter in sedimentary basins and of the dissolved oxygen in bottom and pore waters. The primary presence of organic matter in light-coloured marls and the availability of oxygen in bottom deposits are evident from the occurrence of bioturbations, particularly abundant in lightbrown, variegated and red varieties of marls. Diversified colouration of marls indicates the development of diagenetic processes in anoxic, dysoxic and oxic conditions. 
The following varieties of induration were distinguished: split hard, hard, brittle hard and soft. This feature is related at least partly to the cementation process by silica, which is documented by streak, lenses and layers of cherts, and usually occurs in marls that show split hard induration. However, the causes of the diversity of hardness are complex. They are both primary, related to the composition of the sediment, and are also diagenetic and result in lithological similarities of marls and siliceous rocks, limestones, clays and siliciclastics. Hard varieties are usually similar to limestones, rarely to fine-grained siliciclastic rocks, whilst a split hard resembles diagenetic siliceous rocks, hard brittle marls are microporous, similar to biogenic siliceous rocks and soft varieties are close to clays.

The grain-size of the marls documents the deposition of fine-grained material, usually finer than silt-sized. Silt- and fine sand-sized grains appear in variable amounts and in dispersed form, as well as in thin streaks, lenses and lamines, forming thin beds of arenaceous variety in some marly complexes, and less commonly very thin beds of calcareous sandstones. This indicates an episodic, diversified but generally negligible supply of relatively coarse, sand-sized material during sedimentation of marls.

Bedding of marls, ranging widely in thickness from very thin to very thick (from about $1 \mathrm{~cm}$ to more than $10 \mathrm{~m}$ ), documents a variable current regime and activity of the sources that supply fine-grained material to the basins of diversified bottom topography.

Based on grain-size and bedding, and applying the classification of Ghibaudo (1992), it was possible to distinguish in the marly complexes $\mathrm{M}$ facies (mud beds), usually interbedding with MT (mud-silt couplets) and MS (mud-sand couplets) facies. Moreover, olistostromes and olistoliths of marls have been assigned to the MyG facies (muddy gravel). In composite beds belonging to the MS facies, the dominance of a finer grained member (mud division) usually corresponds to the ratio 1:30, i.e. more than generally accepted for flysch deposits (1:5).

The analysis of internal structures of marly beds, sometimes with a shale cap (M facies) and with silt- or sand-sized grains bearing division at the base (MT and MS facies), has shown that in general they represent $\lg$ subfacies (laminated to graded beds) and document depositional acts composed of several stages.

Lamination is visible in marls, very delicate, usually several millimeters thick, often discontinuous, defined by relatively fine grains, silt- to fine sand-sized, and indicates weak currents reworking deposited sediments. Cross-laminated sandy-silty division of composite bedsets (depositional interval $\mathrm{c}$ and $\mathrm{c}_{0}$ ), often represented by starved ripplemarks, documents the reworking of sediments by bottom currents. The parallel lamination (depositional intervals $b, d$ and $e_{1}$ ), which shows variable intensity, records deposition by traction currents that episodically interrupts the settling of particles through the water column (depositional interval $\mathrm{e}_{2}$ ). Relatively dense lamination by streaks of silt, first visible in the Siliceous-Fucoid, Baculite, Żegocina, Jasienica and Dynów Marls, indicates the important role of deposition from traction currents. In general, lamination in marls is delicate and not dense.

Parting of marls, visible in outcrops, can be thick; slabby and flaggy, describing well defined lamination and showing response to weathering. Similar parting visible in structureless marls indicates a parallel arrangement of components. The occurrence of massive marls, both laminated and structureless ones that show no parting, documents their differential response to weathering. The difference in fabric and composition of marls is 
evident by the shape of splitters that are formed during hammering. The disintegration into fragments that show flat splitting surfaces (platy fragmentation) or conchoidal ones (flaky fragmentation) can be observed. Platy fragmentation of marls is related to well-defined laminated fabric. It is frequently visible breaking with conchoidal fracture (flaky fragmentation), appearing both in structureless marls and in a variety that shows partially faint, discontinuous parallel lamination, and can be related to their narrow grain size distribution and homogeneous composition.

Marls-bearing complexes are mono- and polylithic. Monolithic complexes consist of marls belonging to the $\mathrm{M}$ facies (Węglówka Marls) and of interbedding M and MT facies (Leluchów Marls), M and MS facies (Jasienica Marls) as well as of M, MT and MS facies (Fukoid-Siliceous, Żegocina, Sub-Cergowa and Dynów Marls). The content (frequency percentage) of sandstones in these complexes does not exceed $5 \%$. Polylithic complexes consist of packages of marls that belong to interbedding M, MT and MS facies. They occur within sandstone-shaly flysch (Łącko, Zembrzyce, Budzów and Niwa Marls). The transport directions established for the Lącko Marls are transverse to those of sandstone-shaly flysch deposits (Bromowicz 1992a; Bromowicz, Górniak 1988). Limestones, ferrous dolomites, cherts and phosphoritic concretions, that appear in marly complexes are combined with marly sedimentation and can be related to the primary composition of parent sediments and to the conditions of their diagenesis. The deposits of MyG facies with marly olistoliths (Goleszów and Węgierka Marls) should be assigned to monolithic complexes, whereas those of the MyG facies that contain blocks of extrabasinal origin (Frydek Marls) should be assigned to polylithic ones.

Lateral extension of the marl-bearing complexes is limited. In general they are lensshaped. The thickness of marly bodies, which is often difficult to establish, is very differentiated. Monolithic complexes are from 4 meters (Leluchów Marls) to about $500 \mathrm{~m}$ thick (Siliceous-Fucoid marls). In polylithic complexes marls appear within the sandstoneshaly flysch, up to $2000 \mathrm{~m}$ thick (Zembrzyce Marls). Expending of the thickness of some marly facies can be related to intense redeposition of primary sediments for these rocks.

Marls represent sediments redeposited from shelves and shelf-related environments, transported and reworked by traction and bottom currents, which more or less frequently interrupted suspension settling of grains through the water column. The MS facies, appearing in the majority of the marly complexes studied, is considered to represent incomplete, base-cut-out sequence of Bouma type. Such complexes can be assigned, at least partly, to fine-grained turbidites composed of a thick mud member. Depressions in the morphologically diversified bottom of sedimentation basins of marls could enable local formation of a quiet water environment, causing deposition of beds of very thick finegrained member (beds of $\mathrm{e}_{2} \mathrm{M}$ type). In the cases of the Leluchów Marls ( $\mathrm{M}$ and MT facies) and the Wegglówka Marls (M facies), the contribution of deposition from traction currents, interrupting episodic suspension settling of grains through the water column, is negligible. The Goleszów and Węgierka Marls occur as olistoliths and represent products of submarine debris flows, redeposited from a shallow water environment and shelves in the rigid form (blocks) of intrabasinal origin.

Olistoliths, olistostromes and submarine slump deposits, which occur in marl-bearing complexes, indicate sedimentation in conditions of tectonic disquiet. Intercalations of tuffites, which occur mainly in isochronous equivalents of marls and also sporadically 
within marl-bearing complexes, document volcanic activity related to tectonically disquiet periods.

The stratigraphic position of marls, analyzed against the background of the stages distinguished in tectonic evolution of the Outer Carpathian Basin, indicate that these sediments initiated the stage of its opening (Goleszów Marls) and appeared at the stage of its reconstitution (Siliceous-Fucoid, Węgierka, Węglówka, Frydek, Jasienica and Żegocina Marls). Moreover, they were formed at the closing stage of all the Outer Carpathian SubBasins (Łącko, Zembrzyce, Budzów, Grybów, Sub-Cergowa, Leluchów, Niwa and Dynów Marls) (Fig. 1).

Preorogenic marls, which initiated the opening stage of the Outer Carpathian Basin (Goleszów Marls), represent the products of submarine mass movements (MyG facies), developed as olistostrome containing blocks of black marls. Marls that appeared at the stage of reconstitution of this basin are represented by thin-bedded, gray and light brown, laminated deposits containing cherts (Siliceous-Fucoid, Jasienica and Żegocina Marls), belonging to the M, MT and MS facies (turbidites and contourites) as well as medium- to thick-bedded, massive variegated marls (Weglówka Marls) assigned to the $\mathrm{M}$ facies (hemipelagites and contourites). At the margin of the sub-basins, marls that close the reconstitution stage again represent the MyG facies. They appear as olistostromes with olistoliths of light brown marls (Węgierka Marls) and olistostromes of bluish-gray marly deposits (matrix) with blocks of rocks of extrabasinal origin (Frydek Marls). The distribution of facies reflects the conditions that favour the sedimentation of various genetic types of marls in an area of the northern part of the Carpathian Basin, related to the changes in morphology of its bottom and the separation of the Skole Basin, as an effect of the uplifting of the Sub-Silesian Ridge. The source area of material for marls of the Skole Unit (Siliceous-Fucoid and Węgierka Marls) was the shelf of the northern part of the Carpathian Basin. The marls that appear in the area of Sub-Silesian Ridge (Węglówka, Frydek, Żegocina and Jasienica Marls) are related to the conditions that correspond to the shelf environments, formed within this ridge. Preorogenic marls, with the exception of the Frydek ones, form monolithic complexes.

Synorogenic marls, which occur in the Magura Basin (Łącko, Zembrzyce, Budzów and Niwa Marls), as well as in Fore-Magura (Grybów and Sub-Cergowa Marls) and Skole Basins (Dynów Marls) at the stage of their successive closing are, in general, lithologically similar. Consequently, it is reasonable to accept Bromowicz's (1992a, b) opinion concerning the Magura Basin that the lithological similarities indicate the occurrence of similar catastrophic sedimentation in these basins caused by similar surroundings. Synorogenic marls are turbidites, less commonly tractionites, that are gray and brown in colour. They are both thin- and very thick-bedded and represent the MS, MT and M facies. A thin complex of variegated marls only appears locally (Leluchów Marls), representing the M and MT facies. Synorogenic marls form the first polylithic and successively monolithic complexes.

The analysis of the evolution of the Carpathian Basins during marly sedimentation indicates that they represent, in general, starved basins. A limited supply of siliciclastic material draws our attention to the source of an important component of marls - clay minerals. The occurrence of bentonites in synchronous deposits can indicate a pyroclastic material as a source for the clay minerals that occur in the Carpathian marls. 
The marl depositional system that favour the sedimentation of these rocks in the Outer Carpathians Basin originated under conditions of tectonic disquiet and accompanying volcanic activity. The resulting catastrophic sedimentation in starved basins, accommodated from shelves and submarine ridges, often caused the deposition of sediments in depressions of the sea bottom, and the formation of fairly thick marly beds. Consequently, Carpathian marls represent pre- and syn-orogenic trap-type sediments.

Other authors' data, and the detailed profiling by the present author of locus typicus outcrops of marls that are related to tectonics of the Outer Carpathians, allowed the collection, systematization and extention of geological knowledge on the evolution of these marly facies in northern part of the Tethyan Ocean. The methods used also allowed the present author to present a new insight into this problem, which is important for the interpretation of the geologic evolution of the Outer Carpathians.

Acknowledgements. I express my sincere thanks to the reviewers of this paper. Thanks to their suggestion and comments, the manuscript was greatly improved. The paper benefited greatly from discussion of the results with Professor Jan Bromowicz and Professor Wojciech Narębski. I am very grateful to Professor Narębski for his help with the English script. I wish to thank Dr. Tadeusz Szydłak for helping with the fieldwork, and the drafting and editing of the final manuscript. Thanks also go to Dr. Zbigniew Paul and to Dr. Leszek Jankowski for their advice on the outcrop locations of the Jasienica Marls and the Żegocina, Frydek and Grybów Marls respectively. This work was supported in part by the AGH University of Science and Technology, Grant no. 11.11.140.158 and Grant no. 18.18.140.174. I am indebted to Professor Jacek Matyszkiewicz, the Dean of the Faculty of Geology, Geophysics and Environmental Protection, AGH University of Science and Technology, for his support, help and patience.

\section{References}

Bieda, F., Geroch, S., Koszarski, L., Książkiewicz, M., \& Żytko, K. (1963). Stratigraphie des Karpates externes polonaises. Biuletyn Państwowego Instytutu Geologicznego, 181, 5-174.

Birkenmajer, K., \& Dudziak, (1988). Nannoplankton dating of the terminal flysch deposits (Oligocene) in the Magura Basin, Outer Carpathians. Bulletin of the Polish Academy of Sciences. Earth Sciences, 36(1), 113.

Birkenmajer, K., \& Oszczypko, N. (1989). Cretaceous and Palaeogene lithostratigraphic units of the Magura Nappe. Krynica Subunit, Carpathians. Annales Societatis Geologorum Poloniae, 59, 145-181.

Blaicher, J. (1961). Poziom wapiennej mikrofauny w górnym eocenie serii magurskiej. Biuletyn Państwowego Instytutu Geologicznego, 166, 5-59.

Blaicher, J., \& Sikora, W. (1967). Stratygrafia jednostki rychwałdzkiej w Leluchowie. Kwartalnik Geologiczny, $11(4), 453-454$.

Boggs, S. Jr. (2009). Petrology of sedimentary rocks (2 ed.). Cambridge, New York, Melbourne: Cambridge University Press.

Brasher, I.E. \& Vagle, K.R., (1996). Influence of lithofacies and diagenesis on Norwegian North Sea chalk reservoirs. AAPG Bulletin, $80(5)$, 746-768

Bromowicz, J. (1974). Zmienność facjalna i wykształcenie litologiczne piaskowców inoceramowych jednostki skolskiej między Rzeszowem a Przemyślem. Prace Geologiczne, Polska Akademia Nauk, Oddziat w Krakowie, 84, 1-83.

Bromowicz, J. (1986). Zróżnicowanie petrograficzne obszarów źródłowych warstw ropianieckich na wschód od Dunajca (Polskie Karpaty Zewnętrzne). Annales Societatis Geologorum Poloniae, 56, 253-276. 
Bromowicz, J. (1992a). Basen sedymentacyjny i obszary źródłowe piaskowców magurskich. Zeszyty Naukowe AGH, Geologia, 54, 1-122. The sedimentary basin and source areas of the Magura Sandstones. Scientific Bulletins of University of Mining and Metallurgy, Geology, 54, 1-122.

Bromowicz, J. (1992b). Petrografia i charakterystyka sedymentologiczna margli łąckich, ogniwo z Maszkowic, formacja magurska. Wycieczka B.1.1 Czaczów. In W. Zuchiewicz \& N. Oszczypko (Eds.), Przewodnik LXIII Zjazdu Polskiego Towarzystwa Geologicznego, Koninki (pp. 107-111). Kraków: Instytut Nauk Geologicznych PAN.

Bromowicz, J. \& Otfinowski, M. (1975). Skały węglanowe i bentonit z fliszowych utworów górnej kredy w okolicy Rybotycz (Karpaty przemyskie). Geologia, 1(3), 33-38.

Bromowicz, J. \& Górniak, K. (1988). Litologia i sedymentacja margli łąckich wschodniej części płaszczowiny magurskiej (Karpaty Fliszowe). Annales Societatis Geologorum Poloniae, 58(3-4), 385-421.

Bromowicz, J. \& Oszczypko, N. (1992). Charakterystyka sedymentologiczna i petrograficzna ogniwa z Maszkowic. Wycieczka B.1.9 Maszkowice. In W. Zuchiewicz \& N. Oszczypko (Eds.), Przewodnik LXIII Zjazdu Polskiego Towarzystwa Geologicznego, Koninki (pp. 144-149). Kraków: Instytut Nauk Geologicznych PAN.

Burzewski, W. (1966). Margle bakulitowe na tle litostratygrafii górnych warstw inoceramowych w Karpatach skibowych. Zeszyty Naukowe Akademii Górniczo-Hutniczej w Krakowie, 7(123), 89-115.

Cieszkowski, M. (1992). Strefa Michalczowej - nowa jednostka strefy przedmagurskiej w Zachodnich Karpatach Fliszowych i jej geologiczne otoczenie. Zeszyty Naukowe AGH, Geologia, 18(1-2), 1-125

Cieszkowski, M., Golonka J., Krobicki, M., Ślączka, A., Waśkowska, A. \& Wendorff, M. (2009). Olistolity w serii Śląskiej i ich związek z fazami rozwoju basenu śląskiego. Geologia, 35(2/1), 13-21.

Cieszkowski, M., Malata, E. \& Wieser, T. (1985). Stratigraphic position of the Sub-Magura beds and tuff horizons in Pewel Mała (Beskid Żywiecki Mts.). In T. Wieser (Ed.), Fundamental Researches in the Western Part of the Polish Carpathians. Guide to Excursion 1, Carpathian-Balkan Geological Association, XIII Congress, Cracow, Poland (pp. 49-57). Warszawa: Geological Institute, Poland.

Cieszkowski, M. \& Olszewska, B. (1986). Malcov Beds in Magura Nappe near Nowy Targ, Outer Carpathians, Poland. Annales Societatis Geologorum Poloniae, 56, 53-71.

Gardner, J.V., Dean, W.E. \& Jansa, L. (1978). Sediments recovered from the northwest African continental margin, Leg 41, Deep Sea Drilling Project. In J.V. Gardner \& J. Herring (Eds.), Leg 41 Abidjan, Ivory Coast to Malaga, Spain, February-April, 1975. Initial Reports Deep Sea Drilling Project 41, 1121-1143.

Gasiński, A. M., Jugowiec, M. \& Ślączka, A. (1999). Late Cretaceous foraminiferids and calcareous nannoplankton from the Węglówka Marls (Subsilesian Unit, Outer Carpathian, Poland). Geologica Carpathica 50(1), 63-73.

Gedl, P. \& Leszczyński, S., (2005). Palynology of the Eocene-Oligocene transition in the marginal zone of the Magura Nappe at Folusz (Western Carpathians, Poland). Geologica Carpathica, 56(2), 155-167.

Geroch, S., Jednorowska, A., Książkiewicz, M. \& Liszkowa, J. (1967). Stratigraphy based upon forominifera of the Western Polish Carpathians. Biuletyn Państwowego Instytutu Geoogicznego 211, 185-282.

Geroch, S., Krysowska-Iwaszkiewicz, M., Michalik, M., Prochazka, K., Radomski, A., Radwański, Z., Unrug, Z., Unrug, R. \& Wieczorek, J. (1979). Sedymentacja margli z Węgierki. Rocznik Polskiego Towarzystwa Geologicznego, 49(1/2), 105-133.

Ghibaudo, G. (1992). Subaqueous sediment gravity flow deposits: practical criteria for their field description and classification. Sedimentology, 39(3), 423-454.

Golonka, J., Oszczypko, N. \& Ślączka, A. (2000). Late Carboniferous-Neogene geodynamic evolution and paleogeography of the Circum-Carpathian region and adjacent areas. Annales Societatis Geologorum Poloniae, 70, 107-136.

Golonka, J., Vašiček, Z., Skupien, P., Waśkowska-Oliwa, A., Krobicki, M., Cieszkowski, M., Ślączka, A. \& Słomka, T. (2008). Litostratygrafia osadów górnej jury i dolnej kredy zachodniej części Karpat Zewnętrznych (propozycja do dyskusji). Geologia, 34(3/1), 9-31.

Gucik. S. (1988). Margle z Węgierki jako surowiec materiałów wiążących. In Kotlarczyk, J., Pękała, K. (Eds.), Przewodnik LIX Zjazdu Polskiego Towarzystwa Geologicznego. Przemyśl 16 -18.09. 1988, (pp. 175179). Kraków: Wydawnictwo AGH.

Jasionowicz, J., Koszarski, L. \& Szymakowska, F., (1959). Geologiczne warunki występowania konkrecji fosforytowych w pstrych marglach węglowieckich (górna kreda Karpat Środkowych). Geological Condition of Occurence of Phosphoritic Concretions in the Weglowka variegated Marls (Upper Cretaceous of the Middle Carpathians. Kwartalnik Geologiczny 3(4), 1016-1023. 
Jucha, S. \& Kotlarczyk, J. (1961). Seria menilitowo-krośnieńska w Karpatach fliszowych. La serie des couches a Menilite et des couches a Krosno dans le flysch des Karpates. PAN Oddział w Krakowie, Komisja Nauk Geologicznych, Prace Geologiczne, 4, 1-115

Jugowiec-Nazarkiewicz, M. (2007). Nanoplankton wapienny górnokredowych facji pelagicznych jednostki podślaskiej Polskich Karpat Fliszowych. Calcareous nannoplankton from Upper Cretaceous Pelagic facies of the Subsilesian Unit, Polish Outer Carpathians. Biuletyn Państwowego Instytutu Geologicznego, 426, 53-70.

Jugowiec-Nazarkiewicz, M. \& Jankowski, L., (2001). Biostratygrafia nannoplanktonowa margli żegocińskich; nowe spojrzenie na budowę geologiczną strefy lanckorońsko-żegocińskiej. Przegląd Geologiczny, 49(12), 1186-1190.

Kopciowski, R. (1996). Geological structure of the Siary zone between Ropa and Banica (the Magura nappe). (in Polish, English summary). Biuletyn Państwowego Instytutu Geologicznego, 374, 21-39.

Koszarski, L. (1963). Types fondamentaux des dépots et principales étapes de leur developpment dans le géosynclinal du flysch des Karpates Septentrionales. In: Association Géologique Karpato-Balkanique, V-eme Congrès, Bucarest, III/1, 1, 253-267.

Koszarski, L. (1985a). Stop 8. Szczepanowice: Cretaceous sequence with calcareous flysch of the central zone of the Skole Nappe and the problem of detachment of this unit. In L. Koszarski (Ed.), Geology of the Middle Carpathians and the Carpathian Foredeep. Guide to excursion 3, Carpatho-Balcan Geological Association, XIII Congress, Cracow, Poland (pp. 69-75). Kraków: Geological Institute, Poland.

Koszarski, L. (1985b). Stop 63. Żegocina: Profile of tectonic Żegocina zone and problem of its multi-stage deformation. In L. Koszarski (Ed.), Geology of the Middle Carpathians and the Carpathian Foredeep. Guide to excursion 3, Carpatho-Balcan Geological Association, XIII Congress, Cracow, Poland (pp. 247-248). Kraków: Geological Institute, Poland.

Koszarski, L. (1985c). Tectonic units of the Polish Outer Carpathians. In L. Koszarski (Ed.), Geology of the Middle Carpathians and the Carpathian Foredeep. Guide to excursion 3, Carpatho-Balcan Geological Association, XIII Congress, Cracow, Poland (pp. 30-39). Kraków: Geological Institute, Poland.

Koszarski, L. (1985d). Stop 57, Grybów. Tectonic window and its bordering. In L. Koszarski (Ed.), Geology of the Middle Carpathians and the Carpathian Foredeep. Guide to excursion 3, Carpatho-Balcan Geological Association, XIII Congress, Cracow, Poland (pp. 232-234). Kraków: Geological Institute, Poland.

Koszarski, L. (1985e). General remarks on the geology of the Dukla Unit and their relation to the Fore-Magura Zone. In L. Koszarski (Ed.), Geology of the Middle Carpathians and the Carpathian Foredeep. Guide to excursion 3, Carpatho-Balcan Geological Association, XIII Congress, Cracow, Poland (pp. 193-201). Kraków: Geological Institute, Poland.

Koszarski, A. \& Koszarski, L. 1985a. Structure of Magura nappe SW of Dukla. In L. Koszarski (Ed.), Geology of the Middle Carpathians and the Carpathian Foredeep. Guide to Excursion 3. Carpatho-Balkan Geological Association, XIII Congress, Cracow, Poland (pp. 210-212). Kraków: Geological Institute, Poland.

Koszarski, A. \& Koszarski, L. 1985b. Marginal zone of the Magura Nappe and its relation to lower units. In L. Koszarski (Ed.) Geology of the Middle Carpathians and the Carpathian Foredeep. Guide to Excursion 3. Carpatho-Balkan Geological Association, XIII Congress, Cracow, Poland (pp. 216-219). Kraków: Geological Institute, Poland.

Koszarski, L. \& Koszarski, A. 1985c. Paleogene flysch sequence of the Dukla Unit. Stop 45. Lipowica: Subcergowa marls and Cergowa thick-bedded sandstones. In L. Koszarski, (Ed.), Geology of the Middle Carpathians and the Carpathian Foredeep. Guide to excursion 3, Carpatho-Balcan Geological Association. XIII Congress, Cracow, Poland (pp. 202-204). Kraków: Geological Institute, Poland.

Koszarski, L. \& Ślączka, A., (1973). Kreda Karpat Zewnętrznych. In S. Sokołowski (Ed.), Budowa Geologiczna Polski, tom I, Stratygrafia, część 2, Mezozoik (658-669; 726-733). Warszawa:Wydawnictwa Geologiczne.

Koszarski, L. \& Wieser, T. (1960). Nowe horyzonty tufowe w starszym paleogenie Karpat Fliszowych. New tuff horizons in older Palaeogene of Flysch Carpathians. Instytut Geologiczny, Kwartalnik geologiczny, 4(3), 749-771.

Koszarski, L. \& Wieser, T. (1963). Bentonitized tuffs in the complex of Menilite Silex Rocks in the Flysch Carpathians. Bulletin de l'Académie Polonaise de Sciences. Série des Sciences Géologiques et Géographiques, 10(1), 3-10.

Koszarski, L., Wieser, T. \& Żgiet, J. (1962). Komunikat o występowaniu skał tufowych w dolnej i środkowej kredzie Karpat Polskich. Kwartalnik Geologiczny, 6(2), 441-442. 
Kotlarczyk, J. (1966). Poziom diatomitowy warstw krośnieńskich na tle budowy geologicznej jednostki skolskiej w Karpatach Polskich. Diatomite horizon of the Krosno beds in the Skole Nappe, Polish Carpathians. Studia Geologica Polonica, 19, 1-129

Kotlarczyk, J. (1978). Stratygrafia formacji z Ropianki (fm), czyli warstw inoceramowych w jednostce skolskiej Karpat fliszowych. Prace Geologiczne Oddziat PAN w Krakowie, 108, 1-82

Kotlarczyk, J. (1979). Podstawy stratygrafii formacji z Ropianki w jednostce skolskiej. In J. Kotlarczyk (Ed.), Stratygrafia formacji z Ropianki (fm). Poziomy z olistolitami w Karpatach Przemyskich. Materiały Terenowej Konferencji Naukowej Sedymentologów. 28-29 czerwiec 1979 (pp. 7-16). Kraków: Wydawnictwo Akademii Górniczo-Hutniczej.

Kotlarczyk, J. (1985). An outline of the stratigraphy of marginal tectonic units of the Carpathian orogen the Rzeszów-Przemyśl area. Second day: Baranów-Rzeszów-Błażowa-Przemyśl. Stop 10: The Dynów Marls, Łysa Góra, Straszydle. In J. Kotlarczyk (Ed.), Geotraverse Kraków-Baranów-Rzeszów-Pezemyśl-Ustrzyki Dolne-Komańcza-Dukla. Guide to excursion 4, Carpatho-Balcan Geological Association, XIII Congress, Cracow, Poland (pp. 39-64; pp. 100-102.). Kraków: Geological Institute, Poland.

Kotlarczyk, J. (1988). Wycieczka A. Problemy sedymentologii, stratygrafii i tektoniki Karpat Przemyskich oraz ich najbliższego przedpola. Jednostka skolska. In J. Kotlarczyk (Ed.), Przewodnik LIX Zjazdu Polskiego Towarzystwa Geologicznego. 16-18 września 1988 (pp. 33-56). Karpaty Przemyskie. Kraków: Wydawnictwo Akademii Górniczo-Hutniczej.

Kozikowski, H. 1956. Ropa-Pisarzowa Unit, a new tectonic unit of the Polish Flysch Carpathians. Biuletyn Państwowego Instytutu Geologicznego, 110, 93-137

Kotlarczyk, J.\& Leśniak, T. (1990). Dolna część formacji menilitowej z poziomem diatomitów z Futomy wjednostce skolskiej Polskich Karpat. Lower part of the Menilite Formation and related Futoma Diatomite Member in the Skole Unit of the Polish Carpathians. Wydawnictwo Akademii GórniczoHutniczej, Kraków, 1-73.

Książkiewicz, M. (1935). Budowa brzeżnych mas magurskich między Sułkowicami a Suchą. Rocznik Polskiego Towarzystwa Geologicznego 11, 104-122. Sur la structure des masses marginales de la nappe Magura entre Sulkowice et Sucha (In Polish, French summary). Annales de la Société Géologique de Pologne, 11, 104-122.

Książkiewicz, M. (1958). Stratygrafia serii magurskiej w Beskidzie Średnim. Biuletyn Instytutu Geologicznego $135,43-96$.

Książkiewicz, M. (Ed.), (1962). Atlas Geologiczny Polski-Zagadnienia Stratygraficzno-Facjalne. Zeszyt 13 Kreda i starszy trzeciorzęd Karpat Zewnętrznych. Instytut Geologiczny, Wydawnictwa Geologiczne, Warszawa. Geological Atlas of Poland. Stratigarphic and Facial Problems. Fasc. 13. Instytut Geologiczny

Książkiewicz, M. (1966a). Geologia Regionu Babiogórskiego. Przewodnik 39 Zjazdu Polskiego Towarzystwa Geologicznego, Babia Góra (pp. 5-59). Warszawa: Instytut Geologiczny.

Książkiewicz, M. (1966b). Geologia regionu babiogórskiego. Wycieczka 3, punkt 13. Przewodnik 39 Zjazdu Polskiego Towarzystwa Geologicznego, Babia Góra (pp. 53-54). Warszawa: Instytut Geologiczny.

Książkiewicz, M. (1966c). Geologia regionu babiogórskiego. Wycieczka 3, punkt 14. Przewodnik 39 Zjazdu Polskiego Towarzystwa Geologicznego, Babia Góra (pp. 5-37; pp. 54-55). Warszawa: Instytut Geologiczny.

Książkiewicz, M. (1972). Budowa geologiczna Polski. T. IV. Tektonika, cz. 3. Wydawnictwa Geologiczne, Warszawa.

Książkiewicz, M. (1974). Objaśnienia do szczegółowej mapy geologicznej Polski. Arkusz Sucha Beskidzka (1014). Wydawnictwa Geologiczne. Warszawa.

Książkiewicz, M. \& Liszkowa, J., (1959). Seria podśląska koło Goleszowa (Śląsk Cieszyński). Kwartalnik Geologiczny, 3(1), 91-101.

Leszczyński, S. (1997). Origin of the Sub-Menilite Globigerina Marl (Eocene-Oligocene transition) in the Polish Outer Carpathians. Annales Societatis Geologorum Poloniae, 67, 367-427.

Leszczyński, S. (2003). Bioturbation structures in the Holownia Siliceous Marls (Turonian-lower Santonian) in Rybotycze (Polish Carpathians). Annales Societatis Geologorum Poloniae, 73(2), 103-122.

Leszczyński, S. \& Malata, E. (2002). Sedimentary condition in the Siary zone (Carpathians) in the Late EoceneEarly Oligocene. Annales Societatis Geologorum Poloniae, 72, 201-239.

Leszczyński, S., Malik, K. \& Kędzierski, M. (1995). Margle krzemionkowe i fukoidowe w rejonie Rybotycz: nowe dane litofacjalne i stratygraficzne (płaszczowina skolska, kreda, Karpaty fliszowe). Annales Societatis Geologorum Poloniae, 65, 43-62. 
Leszczyński, S. \& Uchman, A. (1991). The origin of the variegated shales from flysch of the Polish Carpathians. Geologica Carpathica, 42(5), 279 - 289.

Malata, T. (1996). Analysis of standard lithostratigraphic nomenclature and proposal of division for Skole unit in the Polish Flysch Carpathian. Geological Quarterly, 40(4), 543-554.

Malata, T. \& Poprawa, P. (2006). Ewolucja tektoniczna subbasenu skolskiego. In N. Oszczypko, A, Uchman \& E. Malata (Eds.), Rozwój paleotektoniczny basenów Karpat Zewnętrznych i Pienińskiego Pasa Skałkowego. Evolution of the Skole subbasin. Palaeotectonic Evolution of the Outer Carpathian and Pieniny Klippen Belt Basins. (pp. 103-110). Kraków: Instytut Nauk Geologicznych Uniwersytetu Jagiellońskiego.

Narębski, W. (1957). O diagenetycznych dolomitach żelazistych z Karpat Fliszowych. Rocznik Polskiego Towarzystwa Geologicznego, 26(1), 29-43.

Narębski, W. (1960). Konkrecje fosforytowe w pstrych marglach węglowieckich (Karpaty Fliszowe). Studium mineralogiczno-genetyczne. Acta Geologica Polonica 10(2), 165-194.

Narębski, W. (1990). Early rift stage in the evolution of western part of the Carpathians: geochemical evidence from limburgite and techenite rock series. Geologický Zbornik Geologica Carpathica, 41, 521-528.

Nowak, J. (1924). Geologia Krynicy. Kosmos, 59, 449-499.

Nowak, W. (1973a). Jura Karpat Zewnętrznych. In S. Sokołowski (Ed.), Budowa Geologiczna Polski, tom I, Stratygrafia, część 2, Mezozoik. (pp. 401-408; pp. 464-467).Warszawa: Wydawnictwa Geologiczne. The Outer (Flysch) Carpathians. The Jurassic. In: Sokołowski, S. (Ed.), Geology of Poland. I. Stratigraphy, part 2, Mesozoic (pp. 401-408; pp. 464-467). Warsow: Geological Institute.

Nowak, W. (1973b). Kreda górna Karpat Zewnętrznych. In S. Sokołowski (Ed.), Budowa Geologiczna Polski, tom I, Stratygrafia, część 2, Mezozoik (pp. 658-669). Warszawa: Wydawnictwa Geologiczne. The Outer (Flysch) Carpathians. The Upper Cretaceous. In Sokolowski, S. (Ed.), Geology of Poland. I. Stratigraphy, part 2, Mesozoic (pp. 658-669). Geological Institute. Warszawa.

Olszewska, B. (1983). Przyczynek do znajomości otwornic planktonicznych podmenilitowych margli globigerynowych w polskich Karpatach zewnętrznych. Kwartalnik Geologiczny, 27, 547-570.

Olszewska, B. (1984). Otwornice bentoniczne podmenilitowych margli globigerynowych polskich Karpat zewnętrznych. Prace Instytutu Geologicznego, 110, 1-37.

Olszewska, B., (1997). Foraminiferal biostratigraphy of the Polish Outer Carpathians: a record of basin geohistory. Annales Societatis Geologorum Poloniae, 67, 325-337.

Olszewska, B. \& Malata, E. (2006). Analiza paleośrodowiskowa i paleobatymetryczna zespołów mikroskamieniałości polskich Karpat zewnętrznych. Palaeoenvironmental and palaeobatymetric analysis of microfossil assemblages of the Polish Outer Carpathians. In N. Oszczypko, A. Uchman \& E. Malata (Eds.), Rozwój paleotektoniczny basenów Karpat Zewnętrznych i Pienińskiego Pasa Skałkowego. Palaeotectonic Evolution of the Outer Carpathian and Pieniny Klippen Belt Basins (pp. 61-84). Kraków: Instytut Nauk Geologicznych Uniwersytetu Jagiellońskiego.

Olszewska, B., Szydło, A., Jugowiec-Nazarkiewicz, M. \& Nescieruk, P. (2008). Zintegrowana biostratygrafia węglanowych osadów warstw cieszyńskich w Polskich Karpatach Zachodnich. Integrated biostratigraphy of carbonate sediments of the Cieszyn Beds in the Polish Western Carpathians. Geologia, 34(3/1), 33-59.

Oszczypko, M., (1996). Calcareous nannoplankton of the globigerina marls (Leluchów marls member) Magura Nappe, West Carpathians. Annales Societatis Geologorum Poloniae, 66, 1-15.

Oszczypko-Clowes, M. (1998). Late Eocene-Early Oligocene calcareous nannoplankton and stable isotopes $\left(\delta^{13}\right.$ $\left.\mathrm{C}, \delta^{18} \mathrm{O}\right)$ of the Globigerina Marls in the Magura Nappe (West Carpathians). Slovak Geological Magazine, 4(2), 95-107.

Oszczypko-Clowes, M. (2001). The nanofossils biostratigraphy of the youngest deposits in the Magura nappe (east of the Skawa River, Polish flysch Carpathians) and their palaeoenviromental condition. Annales Societatis Geologorum Poloniae, 71, 139-188.

Oszczypko-Clowes, M. \& Ślączka, A. (2006). Nannofossil biostratigraphy of the Oligocene deposits in the Grybów tectonic window (Grybów Unit, Western Carpathians, Poland). Geologica Carpathica, 57 (6), 473-482.

Oszczypko-Clowes, M. \& Oszczypko, N. (2011). Stratigraphy and tectonics of a tectonic window in the Magura Nappe (Świątkowa Wielka, Polish Outer Carpathians). Geologica Carpathica, 62(2), 139-154.

Oszczypko, N. (1979). Budowa geologiczna północnych stoków Beskidu Sądeckiego między Dunajcem a Popradem (płaszczowina magurska). Rocznik Polskiego Towarxystwa Geologicznego, 49(3-4), 293-325.

Oszczypko, N. (1991). Stratigraphy of the Palaeogene deposits of the Bystrica Subunit (Magura Nappe, Polish Outer Carpathians). Bulletin Polish Academy of Sciences, Earth Sciences, 39, 415-431. 
Oszczypko, N. (1992). Late Cretaceous trough Paleogene evolution of Magura Basin. Geologica Carpathica 43, $333-338$

Oszczypko, N. (1999). From remnant oceanic basin to collision-related foreland basin: a tentative history of the Outer Western Carpathians. Geologica Carpathica, 50 (Special issue), 161-163.

Oszczypko, N. (2004). The structural position and tectonosedimentary evolution of the Polish Outer Carpathian. Przegląd Geologiczny 52(8/2), 780-791.

Oszczypko, N. (2006). Pozycja polskich Karpat Zewnętrznych w systemie alpejsko-bałkańskim oraz główne etapy rozwoju orogenu. Position of the Polish Outer Carpathians in the Alpine Arc and their stages of development. In N. Oszczypko, A. Uchman \& E, Malata (Eds.), Rozwój paleotektoniczny basenów Karpat Zewnętrznych i Pienińskiego Pasa Skalkowego. Palaeotectonic Evolution of the Outer Carpathian and Pieniny Klippen Belt Basins (pp. 11-18). Kraków: Instytut Nauk Geologicznych Uniwersytetu Jagiellońskiego.

Oszczypko, N., Dudziak, J. \& Malata, E. (1990). Stratygrafia Płaszczowiny magurskiej (kreda-paleogen) w Beskidzie Sądeckim. Karpaty Zewnętrzne. Studia Geologica Polonica, 47, 109-181.

Oszczypko, N. \& Oszczypko-Clowes, M. (2006). Rozwój basenu magurskiego. Evolution of the Magura basin. In N. Oszczypko, A. Uchman \& E. Malata, E. (Eds.), Rozwój paleotektoniczny basenów Karpat Zewnętrznych i Pienińskiego Pasa Skatkowego. Palaeotectonic Evolution of the Outer Carpathian and Pieniny Klippen Belt Basins (pp. 133-164). Kraków: Instytut Nauk Geologicznych Uniwersytetu Jagiellońskiego.

Paul, Z., Rączkowski, W., Ryłko, W. \& Wójcik, A. (1996). Objaśnienia do mapy geologicznej Polski 1:50 000. Arkusz Myślenice (996). Warszawa: Państwowy Instytut Geologiczny.

Peszat, Cz. (1968). O wykształceniu dolnych łupków cieszyńskich z Goleszowa. Sprawozdania z Posiedzeń Komisji Naukowych PAN, 11(2), 778-780.

Peszat, Cz. (1971). Wycieczka D-1, Stop 2. Przewodnik XLIII Zjazdu Polskiego Towarzystwa Geologicznego, Kraków, 12-14 września 1971 (pp. 186-191). Warszawa: Wydawnictwa Geologiczne.

Pickering, K., Stow, D., Watson, M. \& Hiscott, R. (1986). Deep-water facies, processes and models: a review and classification scheme for modern and ancient sediments. Earth Sciences Review, 23, 75-174.

Poprawa, P., Malata, T., Oszczypko, N., Słomka, T. \& Golonka, J. (2006). Analiza subsydencji tektonicznej oraz tempa depozycji materiału detrytycznego w basenach sedymentacyjnych Zachodnich Karpat Zewnętrznych. Analysis of tectonic subsidence and sediment deposition rate for the sedimentary basins of the Western Outer Carpathian. In N. Oszczypko, A. Uchman \& E. Malata (Eds.), Rozwój paleotektoniczny basenów Karpat Zewnętrznych i Pienińskiego Pasa Skałkowego. Palaeotectonic Evolution of the Outer Carpathian and Pieniny Klippen Belt Basins (pp. 179-199). Kraków: Instytut Nauk Geologicznych Uniwersytetu Jagiellońskiego.

Potter, P.E., Maynard, J.B. \& Pryor, W.A. (1980). Sedimentology of Shale. Study Guide and Reference Source. New York: Springer-Verlag New York Inc.

Potter, P.E., Maynard, J.B. \& Depetris P.J. (2005). Mud and mudstones. Berlin Heidelberg: Springer-Verlag.

Rajchel, J. (1989). Budowa geologiczna doliny Sanu w rejonie Dynów-Dubiecko. Biuletyn Państwowego Instytutu Geologicznego 361, 11-53.

Reineck, H. E. \& Singh, I.B. (1980). Depositional sedimentary environments. (2 ed.) Berlin: Springer-Verlag.

Sikora, W. (1970). Budowa geologiczna płaszczowiny magurskiej między Szymbarkiem Ruskim a Nawojową. Biuletyn, Instytut Geologiczny, 235, 5-121.

Skoczylas-Ciszewska, K., (1956). O występowaniu andezytów w strefie żegocińskiej Karpat fliszowych. Geologia, 6(1), 143-154.

Skoczylas-Ciszewska, K., (1960). Budowa geologiczna strefy żegocińskiej. Acta Geologica Polonica, X, 4, 485591.

Słomka, T. (1986a). Analiza sedymentacji warstw cieszyńskich metodami statystyki matematycznej. Annales Societatis Geologorum Poloniae, 56, 277-336.

Słomka, T. (1986b). Utwory podmorskich ruchów masowych w łupkach cieszyńskich dolnych. Submarine mass movement deposits in Lower Silesia Shales. Geologia, 12(4), 25-35.

Słomka, T., Malata, T., Leśniak, T., Oszczypko, N. \& Poprawa, P. (2006). Ewolucja basenu śląsko-podśląskiego. Evolution of the Silesian and Subsilesian basins. In N. Oszczypko, A. Uchman \& E. Malata, E. (Eds.), Rozwój paleotektoniczny basenów Karpat Zewnętrznych i Pienińskiego Pasa Skałkowego. Palaeotectonic Evolution of the Outer Carpathian and Pieniny Klippen Belt Basins (pp. 111-126). Kraków: Instytut Nauk Geologicznych Uniwersytetu Jagiellońskiego. 
Stow, D.A.V. (1984). Turbidite facies, associations, and sequences in the southeastern Angola Basin. Deep Sea Drilling Project, 75, Initial Reports, 785-799.

Stow, D.A.V. (1985). Fine-grained sediments in deep water: An overview of processes and facies models. GeoMarine Letters, 5, 17-23.

Szydło, A. (1997). Biostratigraphical and palaeoecological significance of small foraminiferal assemblages in the Silesian (Cieszyn) Unit, Western Carpathians, Poland. Annales Societatis Geologorum Poloniae, 67, $345-$ 354.

Szydło. A. \& Jugowiec. M. (1999). Foroaminifera and calcareous nannoplancton assemblages from ?TithonianNeocomian "Cieszyn Beds" (Silesian Unit, Polish Wester Carpathians). Geologica Carpathica, 50(2), 203-211.

Ślączka, A. 1959. Stratygrafia fałdów dukielskich okolic Komańczy-Wisłoka Wielkiego. Kwartalnik Geologiczny, 3, 583-603.

Ślączka, A. (1971). Geologia jednostki dukielskiej. The Geology of the Dukla Unit (Polish Flysch Carpathians). Prace Instytutu Geologicznego, 63, 1-97.

Ślączka, A. (1973a). Wycieczka 1: Grybów-Polany-Berest-Krzyżówka. Punkt 1-4. In Gucik, S., Ślączka, A. \& Żytko, K. (Eds.), Przewodnik geologiczny po wschodnich Karpatach fliszowych (pp. 78-87). Warszawa: Wydawnictwa Geologiczne.

Ślączka, A. (1973b). Wycieczka 5: Dukla-Lipowica-Trzciana-Jaśliska-Tylawa. Punkt 55. In S. Gucik, A. Ślączka \& K. Żytko (Eds.), Przewodnik geologiczny po wschodnich Karpatach fliszowych (pp. 111-123). Warszawa: Wydawnictwa Geologiczne.

Ślączka, A. (1977a). Uwagi o budowie geologicznej Ziemi Krośnieńskiej. In A. Ślączka (Ed.), Przewodnik XLIX Zjazdu Polskiego Towarzystwa Geologicznego (pp. 7-32). Warszawa: Wydawnictwa Geologiczne.

Ślączka, A. (1977b). Rozwój facjalny i problemy paleogeograficzne młodszego paleogenu jednostki dukielskiej. Materiały Konferencji Terenowych. Problem 1A. Punkt 1 - Lipowica-brzeżna część jednostki dukielskiej; margle podcergowskie. In A. Ślączka (Ed.), Przewodnik XLIX Zjazdu Polskiego Towarzystwa Geologicznego (pp. 74). Warszawa: Wydawnictwa Geologiczne.

Ślączka, A. (1985). Geology of Polish part of Fore-Dukla Zone and Dukla Unit. In J. Kotlarczyk (Ed.), Geotraverse Kraków-Baranów-Rzeszów-Pezemyśl-Ustrzyki Dolne-Komańcza-Dukla. Guide to excursion 4, Carpatho-Balcan Geological Association, XIII Congress, Cracow, Poland (pp. 64-85). Kraków: Geological Institute,Poland.

Ślączka, A. (1998). Age of the andesitic rocks in the Subsilesian unit (Outer Carpathians). Abstracts - CarpathoBalkan Geological Association, XVI Congress (pp. 5). Vienna.

Ślączka, A. \& Kamiński, M. A. (1998a). Stop 42. A guidebook to excursions in the Polish Flysch Carpathians, Grzybowski Foundation Special Publication, 6, 129-131.

Ślączka, A. \& Kamiński, M. A. (1998b). Stop 41. A guidebook to excursions in the Polish Flysch Carpathians. Grzybowski Foundation Special Publication, 6, 125-129.

Ślączka, A. \& Kamiński, M. A. (1998c). Stop 12. A guidebook to excursions in the Polish Flysch Carpathians Grzybowski Foundation Special Publication, 6, 55-59.

Ślączka, A. \& Kamiński, M. A. (1998d). Sedimentary facies and basin history: Oligocene. Stop 21. A guidebook to excursions in the Polish Flysch Carpathians. Grzybowski Foundation Special Publication, 6, 22-23, 74-77.

Ślączka, A. \& Kamiński, M. A. (1998e). Sedimentary facies and basin history: Oligocene. Stop 25. A guidebook to excursions in the Polish Flysch Carpathians, Grzybowski Foundation Special Publication, 6, 22-23, 86-92.

Ślączka, A. \& Kamiński, M. A. (1998f). Stop 22. A guidebook to excursions in the Polish Flysch Carpathians, Grzybowski Foundation Special Publication, 6, 77-82.

Ślączka, A., Oszczypko, N., Malata, E. \& Cieszkowski, M. (1999). An early history of the Outer Carpathian Basin. Geologica Carpathica, Special issue, 170-172.

Ślączka, A., Kruglov, S., Golonka, J., Oszczypko N. \& Popadyuk, I. (2006). The general geology of the Outer Carpathians, Poland, Slovakia and Ukraine. In F. Picha \& J. Golonka (Eds.), The Carpathians and their foreland: Geology and hydrocarbon resources. American Association of Petroleum Geologists, Memoir, 84, 221-258.

Świdziński, H. (1953). Karpaty fliszowe między Dunajcem a Sanem. In Regionalna geologia Polski, 1, 2. Polskie Towarzystwo Geologiczne, Kraków, 362-422.

Świdziński, H. (1963). Excursion B-I-1: Ciężkowice-Grybów-Krosno-Iwonicz Zdrój. In S. Wdowiarz \& W. Nowak (Eds.), Association Géologique Karpato-Balkanique, VI-eme Congrès, Varsovie-Cracovie, Guide des Excursions: Karpates Externes ( pp. 85-91), Varsovie-Cracovie: Wydawnictwa Geologiczne. 
Teisseyre, H. (1930). Sprawozdania z badań geologicznych wykonanych w roku 1929 w okolicy Dukli (arkusz Jasło-Dukla). Sprawozdania Państwowego Instytutu Geologicznego, Warszawa, 5 (3-4), 601-616. Compte-rendu des researches geologiques exécutées en 1929 aux environs de Dukla.

Uhlig, V. (1888). Ergebnisse geologischer Aufnahmen in den westgalizischen Karpathen. Teil I. Jahrbuch der keiserlich-königlischen geologischen Reichsanstalt, Wien, 38, 83-264.

Van Couvering, J.A., Auby, M.P., Berggren, W.A., Bujak, J.P., Naeser, C.W. \& Wieser, T. (1981). The terminal Eocene event and the Polish connections. Palaeogeography, Palaeoclimatology, Palaeoecology, 36, $321-$ 362.

Wdowiarz, S. \& Jucha, S. (1963). Excursion B-II-2: Iwonicz-Krosno-Czarnorzeki-Węglówka-Dukla. Point 10. In S. Wdowiarz \& W. Nowak (Eds.), Association Géologique Karpato-Balkanique, VI-eme Congrès, Varsovie-Cracovie, Guide des Excursions: Karpates Externes, (109-126). Varsovie-Cracovie: Wydawnictwa Geologiczne.

Węcławik, S. (1969). Budowa geologiczna płaszczowiny magurskiej między Ujściem Gorlickim a Tyliczem. PAN Oddział w Krakowie, Komisja Nauk Geologicznych, Prace Geologiczne, 59, 1-96.

Wieser, T. (1954). Skały magmowe Bachowic. The igneous rocks of Bachowice (Western Carpathians). Rocznik Polskiego Towarzystwa Geologicznego, XXII, 223-275.

Wieser, T. (1974). Wyniki badań petrograficznych. In Wdowiarz, S. (Ed.), Budowa geologiczna jednostki skolskiej i jej podłoża w profilu otworu Cisowa IG - 1. Instytut Geologiczny, Biuletyn 273, 20-49.

Wieser, T. (1985). The Teschenite Formation and other evidences of magmatic activity in the Polish Flysch Carpathians and their geotectonic and stratigraphic significance. In Wieser, T. (Ed.), Fundamental Researches in the Western Part of the Polish Carpathians. Guide to Excursion 1, Carpathian-Balkan Geological Association, XIII Congress, Carpatho-Balkan Geological Association, Cracow, Poland. Geological Institute, Poland, Warszawa, 23-36.

Wieser, T. (1994). Origin of the Lower Eocene clinoptilolite-montmorillonite claystones from the Skole Unit of the Flysch Carpathians. Mineralogia Polonica 25(2), 3-20.

Wójcik, A., Kopciowski, R., Malata, T., Marciniec, P. \& Nescieruk, P. (1996). Propozycja podziału jednostek litostratygraficznych polskich Karpat Zewnętrznych. In Przewodnik LXVII Zjazdu Polskiego Towarzystwa Geologicznego. Beskidy Zachodnie - nowe spojrzenie na budowe geologiczna i surowce mineralne. $67^{\text {th }}$ Annual Meeting of Polish Geological Society "Western Beskidy Mts. - new approach to geological structure and natural resources”(pp. 209-215). Kraków: Wydawnictwo Państwowego Instytutu Geologicznego.

Żytko, K., Zając, R., Gucik, S., Ryłko, W., Oszczypko, N., Garlicka, I., Nemčok, J., Eliáš, M., Menčik, E. \& Stránik, Z., (1989). Map of the tectonic elements of the Western Outer Carpathians and their foreland. In D. Poprawa \& J. Nemčok (Eds.), Geological Atlas of the Western Outer Carpathians and their Foreland. Państwowy Instytut Geologiczny Warszawa/GUDŠ Bratislava/Uug Praha. 